\title{
Design, Synthesis, and Biological Evaluation of Triazolone Derivatives as Potent PPAR $\alpha / \delta$ Dual Agonists for the Treatment of Nonalcoholic Steatohepatitis
}

Zhiqi Feng ${ }^{\dagger,}$, , Jiehao Xiang ${ }^{\dagger, a}$, Hui Liu ${ }^{\dagger,}$, Jiaxin Lia, Xiangrui Xua ${ }^{a}$, Gang Sun ${ }^{a}$, Runan

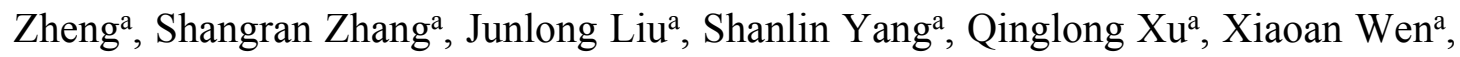
Haoliang Yuan a,*, Hongbin Sun a,b,*, Liang Dai a,*

a Jiangsu Key Laboratory of Drug Discovery for Metabolic Disease, State Key Laboratory of Natural Medicines, China Pharmaceutical University, Nanjing 210009, China

${ }^{\mathrm{b}}$ State Key Laboratory for the Chemistry and Molecular Engineering of Medicinal Resources, School of Chemistry and Pharmacy of Guangxi Normal University, Guilin 541004, China

$\dagger$ These authors contributed equally to this article.

*To whom correspondence should be addressed. Tel: +86-25-83271196. Fax: +86-2583271196. E-mail: dailiang1993@yeah.net (L. Dai); hongbinsun@cpu.edu.cn (H. B. Sun); yhl@cpu.edu.cn (H. L. Yuan) 


\section{Table of contents}

Figure S1. Effects of H11 on HepG2, AML12 or HEK293 cell viability. (S3)

Figure S2. hERG activity of Amitriptyline and H11. (S4)

Figure S3. PK curves of compounds H11 and H41 in SD rats. (S5)

Figure S4. The predicted protein-ligand interactions between PPAR $\alpha-H 11$. (S6)

Figure S5. The predicted protein-ligand interactions between PPAR $\gamma$-H11. (S7)

Table S1. Primers used in Real-Time PCR. (S8)

Table S2. Data collection and refinement statistics for PPAR $\delta$-H11 complex. (S9)

Procedures for preparation of the key intermediates of compounds H0-42. (S10-S17)

Procedures for preparation of GFT-505, IVA-337 and compound 8. (S18-S19)

${ }^{1} \mathrm{H}$ NMR and ${ }^{13} \mathrm{C}$ NMR spectra of compounds H0-42. (S20-S62)

${ }^{1} \mathrm{H}$ NMR spectra of GFT-505, IVA-337 and compound 8. (S63-S64)

UPLC data of compounds H0-42. (S65-S98)

UPLC data of GFT-505, IVA-337 and compound 8. (S99-S101) 
A

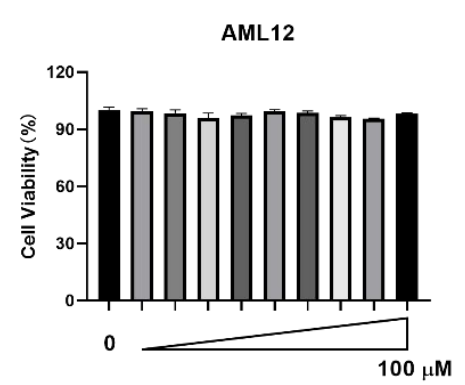

B

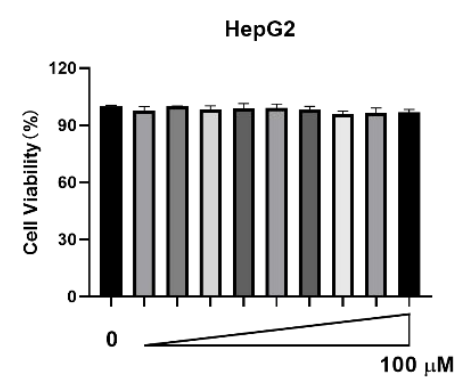

C

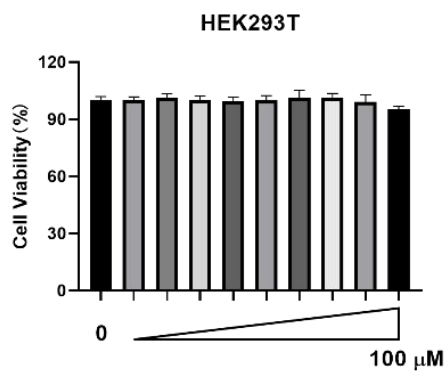

Figure S1. Effects of H11 on cell viability. HepG2 (A), AML12 (B) or HEK293T (C) cells were treated with compound $\mathbf{H 1 1}$ for $24 \mathrm{~h}$. The concentration series encompassed 9 different concentrations in 2-fold dilutions starting from $100 \mu \mathrm{M}$. 

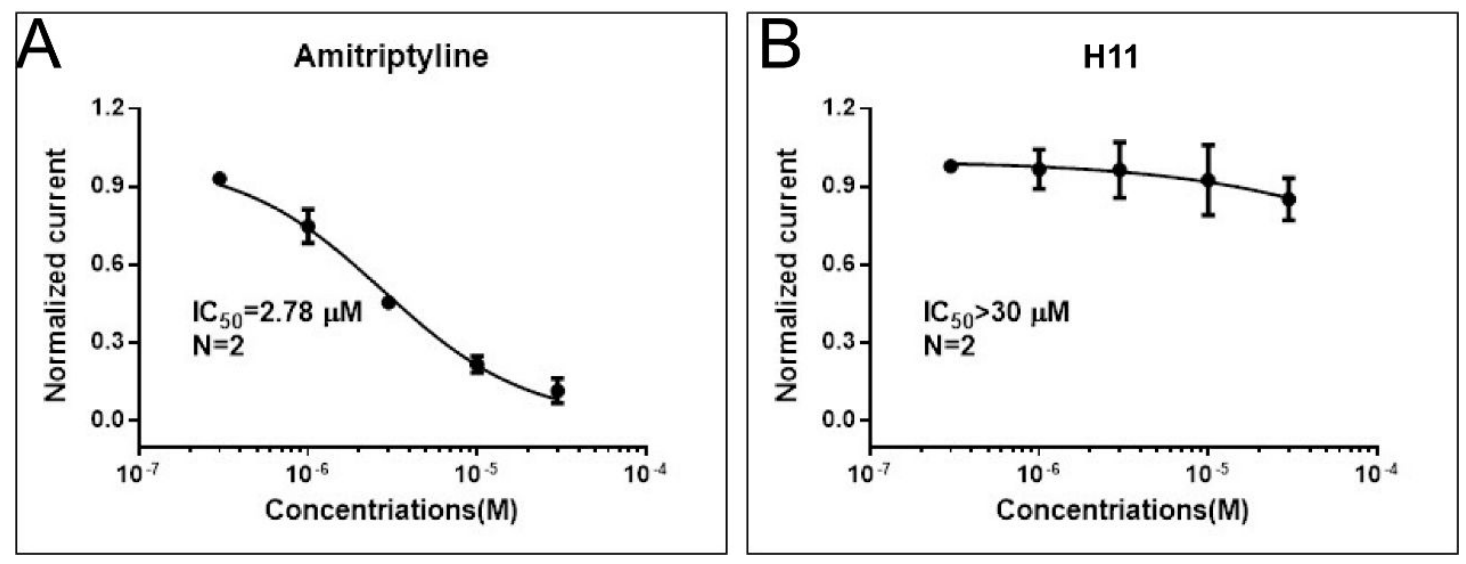

Figure S2. hERG activity of (A) Amitriptyline (positive control) and (B) H11. 
A

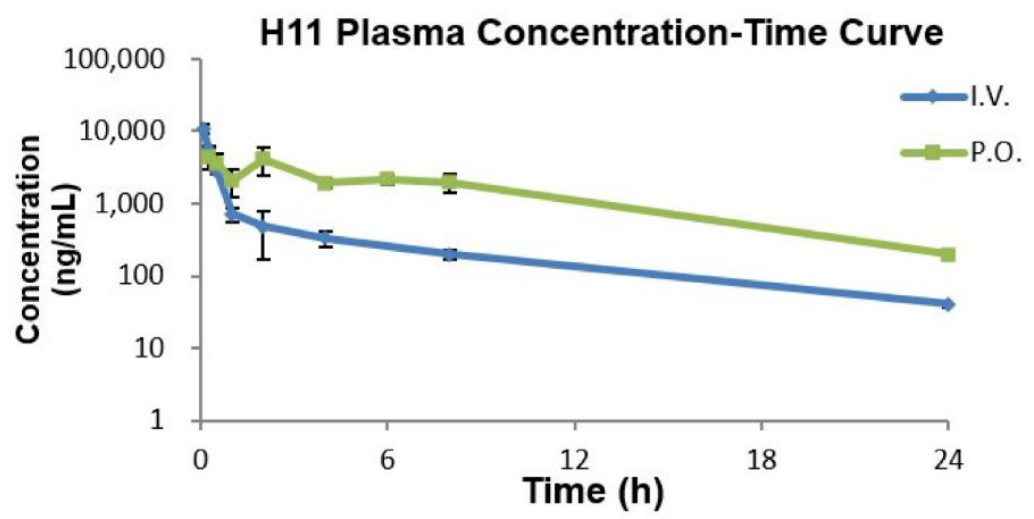

B

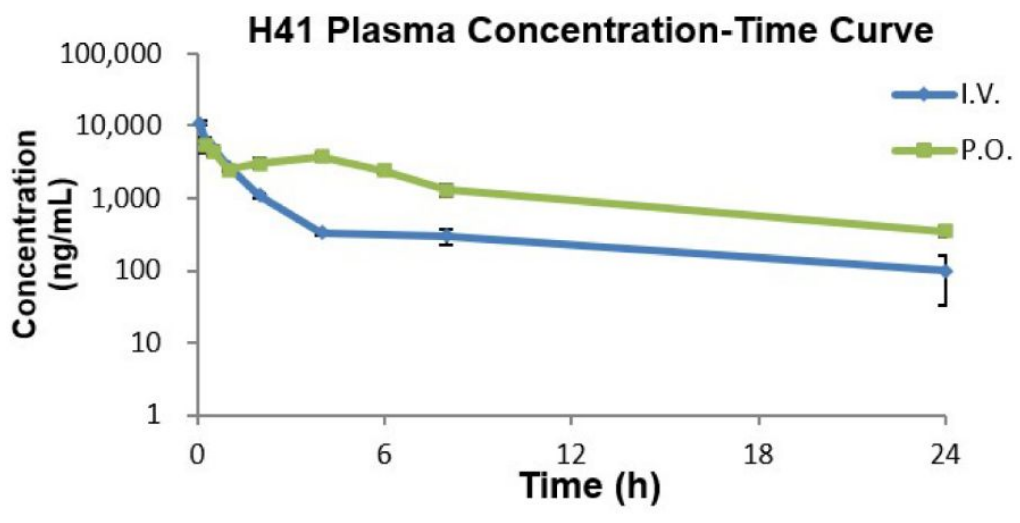

Figure S3. PK curves of $10 \mathrm{mg} / \mathrm{kg}$ oral dose and $2 \mathrm{mg} / \mathrm{kg}$ intravenous dose of H11 (A) and $\mathbf{H 4 1}(\mathrm{B})$ in SD rats. 


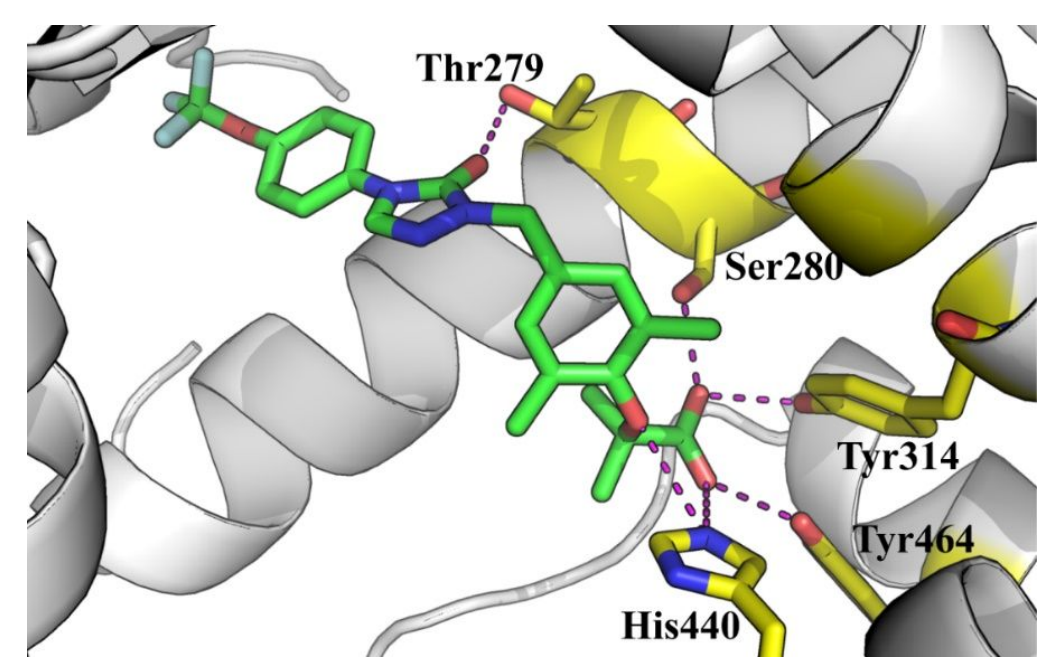

Figure S4. The predicted protein-ligand interactions between PPAR $\alpha$ (PDB: 7BPZ) and H11. The compound exhibited a similar binding conformation in the binding site of PPAR $\delta$. The key hydrogen bond interactions between carboxy group and adjacent residues were observed, including Ser280, Tyr314, His440 and Tyr464. Besides, there was also a corresponding threonine (Thr279) in PPAR $\alpha$ of that (Thr253) in PPAR $\delta$. Therefore, a direct hydrogen bond between the $\mathrm{O}$ atom of the triazolone moiety and Thr279 was observed. 


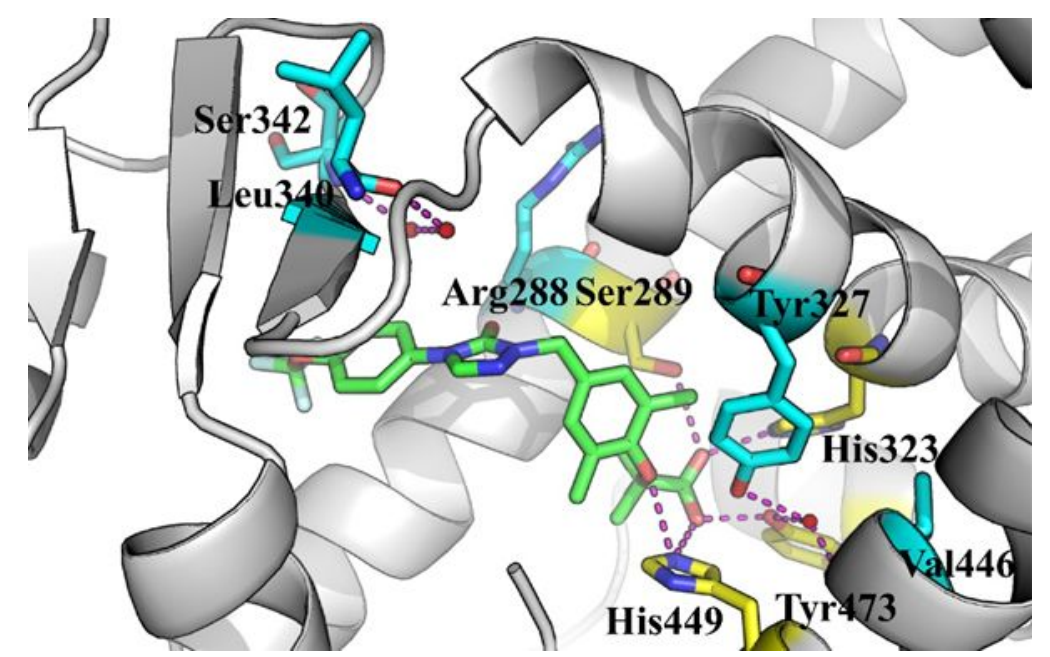

Figure S5. The predicted protein-ligand interactions between PPAR $\gamma$ (PDB: 1I7I) and H11. The docking result revealed that H11 took a similar binding conformation as those in the binding pockets of PPAR $\alpha$ and PPAR $\delta$. The key hydrogen bond interactions were also observed between the carboxy group and adjacent residues in the binding pocket, including His323, Tyr473 and His449. Ser289 in PPAR $\gamma$ was the corresponding residue of Ser280 in PPAR $\alpha$. The same hydrogen bond was also formed between Ser289 and the carboxy group. However, the corresponding residue of Thr279 in PPAR $\alpha$ and Thr253 in PPAR $\delta$ was Arg288 in PPAR $\gamma$ with an unfavorite orientation, leading to absence of the key hydrogen bond interaction between the triazolone moiety and threonines in the other two subtypes. Although there were also three crystal water molecules in the pocket, they were not involved in the protein-ligand interactions. Considering all above, these differences of binding mode resulted in the decreased agonistic activity of $\mathbf{H 1 1}$ against PPAR $\gamma$. 
Table S1. Primers used in Real-Time PCR.

\begin{tabular}{|l|l|}
\hline \multicolumn{1}{|c|}{ Primer } & \multicolumn{1}{c|}{ Sequence } \\
\hline Homo_ACADVL_Forward Primer & ACAGATCAGGTGTTCCATACC \\
\hline Homo_ACADVL_Reverse Primer & CTTGGCGGGATCGTTCACTT \\
\hline Homo_PDK4_Forward Primer & GGAAGCATTGATCCTAACTGTGA \\
\hline Homo_PDK4_Reverse Primer & GGTGAGAAGGAACATACACGATG \\
\hline Homo_CPTlA_Forward Primer & ATCAATCGGACTCTGGAAACGG \\
\hline Homo_CPTlA_Reverse Primer & TCAGGGAGTAGCGCATGGT \\
\hline Homo_ACTIN_Forward Primer & CATGTACGTTGCTATCCAGGC \\
\hline Homo_ACTIN_Reverse Primer & CTCCTTAATGTCACGCACGAT \\
\hline Mus_Acadvl_Forward Primer & CTACTGTGCTTCAGGGACAAC \\
\hline Mus_Acadvl_Reverse Primer & CAAAGGACTTCGATTCTGCCC \\
\hline Mus_Pdk4_Forward Primer & AGGGAGGTCGAGCTGTTCTC \\
\hline Mus_Pdk4_Reverse Primer & GGAGTGTTCACTAAGCGGTCA \\
\hline Mus_Cpt1a_Forward Primer & CTATGCGCTACTCGCTGAAGG \\
\hline Mus_Cpt1a_Reverse Primer & GGCTTTCGACCCGAGAAGA \\
\hline Mus_Angptl4_Forward Primer & CATCCTGGGACGAGATGAACT \\
\hline Mus_Angptl4_Reverse Primer & TGACAAGCGTTACCACAGGC \\
\hline Mus_Tnf_Forward Primer & CCCTCACACTCAGATCATCTTCT \\
\hline Mus_Tnf_Reverse Primer & GCTACGACGTGGGCTACAG \\
\hline Mus_Il1b_Forward Primer & GCAACTGTTCCTGAACTCAACT \\
\hline Mus_Il1b_Reverse Primer & ATCTTTTGGGGTCCGTCAACT \\
\hline Mus_Adgre1_Forward Primer & TGACTCACCTTGTGGTCCTAA \\
\hline Mus_Adgre1_Reverse Primer & CTTCCCAGAATCCAGTCTTTCC \\
\hline Mus_Ccl4_Forward Primer & TTCCTGCTGTTTCTCTTACACCT \\
\hline Mus_Ccl4_Reverse Primer & CTGTCTGCCTCTTTTGGTCAG \\
\hline Mus_Colla1_Forward Primer & GCTCCTCTTAGGGGCCACT \\
\hline Mus_Colla1_Reverse Primer & CCACGTCTCACCATTGGGG \\
\hline Mus_Col3a1_Forward Primer & CTGTAACATGGAAACTGGGGAAA \\
\hline Mus_Col3a1_Reverse Primer & CCATAGCTGAACTGAAAACCACC \\
\hline Mus_Acta2_Forward Primer & GTCCCAGACATCAGGGAGTAA \\
\hline Mus_Acta2_Reverse Primer & TCGGATACTTCAGCGTCAGGA \\
\hline Mus_Tgfb1_Forward Primer & CTCCCGTGGCTTCTAGTGC \\
\hline Mus_Tgfb1_Reverse Primer & GCCTTAGTTTGGACAGGATCTG \\
\hline Mus_Gapdh_Forward Primer & CTTCTCCATGGTGGTGAAGAC \\
\hline Mus_Gapdh_Reverse Primer & CCTTCATTGACCTCAACTACATG \\
\hline
\end{tabular}


Table S2. Data collection and refinement statistics for PPAR $\delta$-H11 complex

\begin{tabular}{|c|c|c|}
\hline PDB ID & & $7 \mathrm{~W} 0 \mathrm{G}$ \\
\hline Space group & & P 21 \\
\hline \multirow[t]{6}{*}{ Cell Dimension: } & $\mathrm{a}(\AA)$ & 39.86 \\
\hline & $\mathrm{b}(\AA)$ & 93.2 \\
\hline & $\mathrm{c}(\AA)$ & 96.71 \\
\hline & alpha $\left(^{\circ}\right)$ & 90 \\
\hline & beta $\left(^{\circ}\right)$ & 96.27 \\
\hline & gamma $\left(^{\circ}\right)$ & 90 \\
\hline \multicolumn{2}{|c|}{ Wavelength $(\AA)$} & 0.9798 \\
\hline \multicolumn{2}{|c|}{ Reflections (unique) } & 25924 \\
\hline \multicolumn{2}{|c|}{ Resolution Range $(\AA)$} & $28.139-2.443$ \\
\hline \multicolumn{2}{|c|}{ Highest-Resolution Shell $(\AA)$} & $2.48-2.443$ \\
\hline \multicolumn{2}{|c|}{ Redundancy } & 3.5 \\
\hline \multicolumn{2}{|l|}{$\mathrm{I} / \sigma(\mathrm{I})$} & 1.380 \\
\hline \multicolumn{2}{|c|}{ Highest-Resolution Shell CC1/2 } & 1.024 \\
\hline \multicolumn{2}{|c|}{ Rwork/Rfree } & $0.1988 / 0.2365$ \\
\hline \multicolumn{3}{|l|}{ RMS Values } \\
\hline \multicolumn{2}{|l|}{ Bond length $(\AA)$} & 0.009 \\
\hline \multicolumn{2}{|c|}{ Bond angle $\left(^{\circ}\right)$} & 1.241 \\
\hline \multicolumn{3}{|c|}{ Numbers of Non-hydrogen Atoms } \\
\hline \multicolumn{2}{|c|}{ Protein } & 4334 \\
\hline \multicolumn{2}{|l|}{ Ligand } & 66 \\
\hline \multicolumn{2}{|l|}{ Water Oxygen } & 18 \\
\hline \multicolumn{2}{|l|}{ Clashscore } & 6.46 \\
\hline \multicolumn{3}{|c|}{ Ramachandran plot } \\
\hline \multicolumn{2}{|c|}{ Favored $(\%)$} & 95.88 \\
\hline \multicolumn{2}{|l|}{ Allowed (\%) } & 4.12 \\
\hline \multicolumn{2}{|l|}{ Outliers (\%) } & 0.00 \\
\hline
\end{tabular}

Statistics for the highest-resolution shell are shown in parentheses. 
Procedures for preparation of the key intermediates of compounds H0-42.

Synthetic procedure for $13 a$

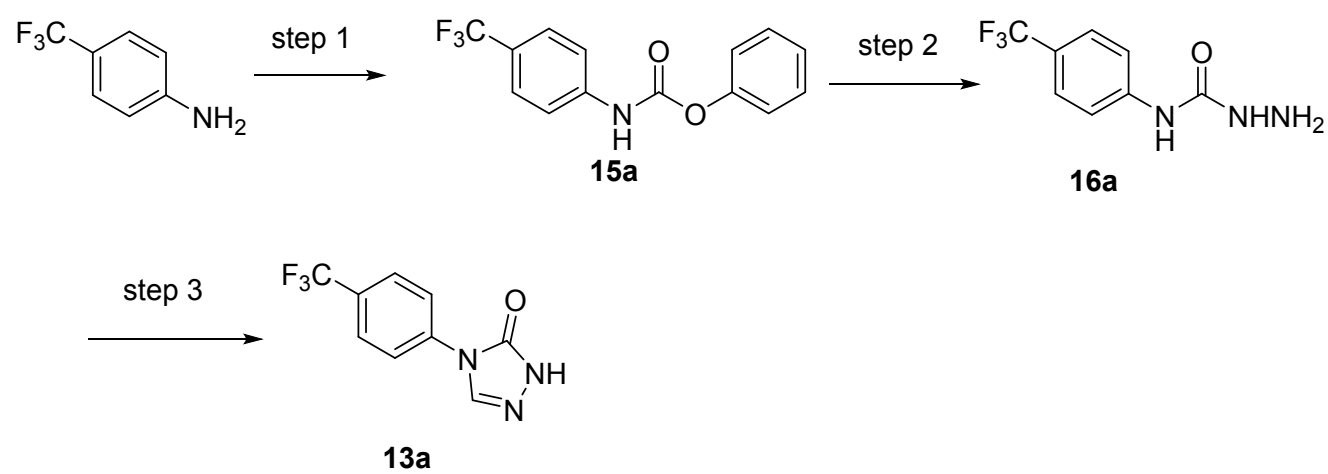

Step 1: A solution of 4-(trifluoromethyl)aniline (3.2 g, $20 \mathrm{mmol})$ in ethyl acetate (EA, $50 \mathrm{~mL})$ was added pyridine $(6.1 \mathrm{~mL}, 22 \mathrm{mmol})$, and phenyl chloroformate $(3.4 \mathrm{~g}, 22$ mmol) dropwise at $0{ }^{\circ} \mathrm{C}$. The mixture was stirred at room temperature for 4 hours. Water $(50 \mathrm{~mL})$ was added to the mixture and extracted with EA $(50 \mathrm{~mL} \times 3)$. The organic phase was washed with brine $(25 \mathrm{~mL})$. The organic phase was concentrated under reduced pressure to $15 \mathrm{a}(5.5 \mathrm{~g}, 98 \%)$.

Step 2: A solution of 15a (4.2 g, $15 \mathrm{mmol})$ in 1, 2-Dimethoxyethane (50 mL) was added hydrazine hydrate $(4.5 \mathrm{~mL}, 90 \mathrm{mmol})$ at room temperature. The mixture was stirred overnight. The mixture was concentrated under reduced pressure to $\mathbf{1 6 a}(3.1 \mathrm{~g}, 95 \%)$.

Step 3: A solution of $16 \mathbf{a}(2.1 \mathrm{~g}, 10 \mathrm{mmol})$ in $\mathrm{CH}_{3} \mathrm{CN}(25 \mathrm{~mL})$ was added formamidine acetate $(0.9 \mathrm{~g}, 30 \mathrm{mmol})$. The mixture was stirred at room temperature for 30 minutes. The mixture was added acetic acid $(3.0 \mathrm{~mL}, 50 \mathrm{mmol})$ at room temperature and was stirred at $80^{\circ} \mathrm{C}$ overnight. The mixture was concentrated under reduced pressure. Water $(50 \mathrm{~mL})$ was added to the residue. The mixture was extracted with EA $(50 \mathrm{~mL} \times 3)$ and washed with brine $(25 \mathrm{~mL})$. The organic phase was concentrated under reduced pressure to rude product. The rude product was purified by silica gel column chromatography $(\mathrm{EA} / \mathrm{PE}=1: 3)$ to give desired $13 \mathrm{a}(1.03 \mathrm{~g}, 45 \%):{ }^{1} \mathrm{H} \mathrm{NMR}(300 \mathrm{MHz}$, $\mathrm{DMSO}_{-} d_{6} \delta 12.12(\mathrm{~s}, 1 \mathrm{H}), 8.53(\mathrm{~s}, 1 \mathrm{H}), 8.01(\mathrm{~d}, J=8.2 \mathrm{~Hz}, 2 \mathrm{H}), 7.88(\mathrm{~d}, J=8.2 \mathrm{~Hz}$, 2H). MS (ESI): $m / z 252.0[\mathrm{M}+\mathrm{Na}]^{+}$.

\section{General synthetic procedure for 13b-13p}


The preparation of $\mathbf{1 3 b - 1 3 p}$ is similar to the procedure of $\mathbf{1 3 a}$.

\section{Synthetic procedure for $17 \mathrm{a}$}
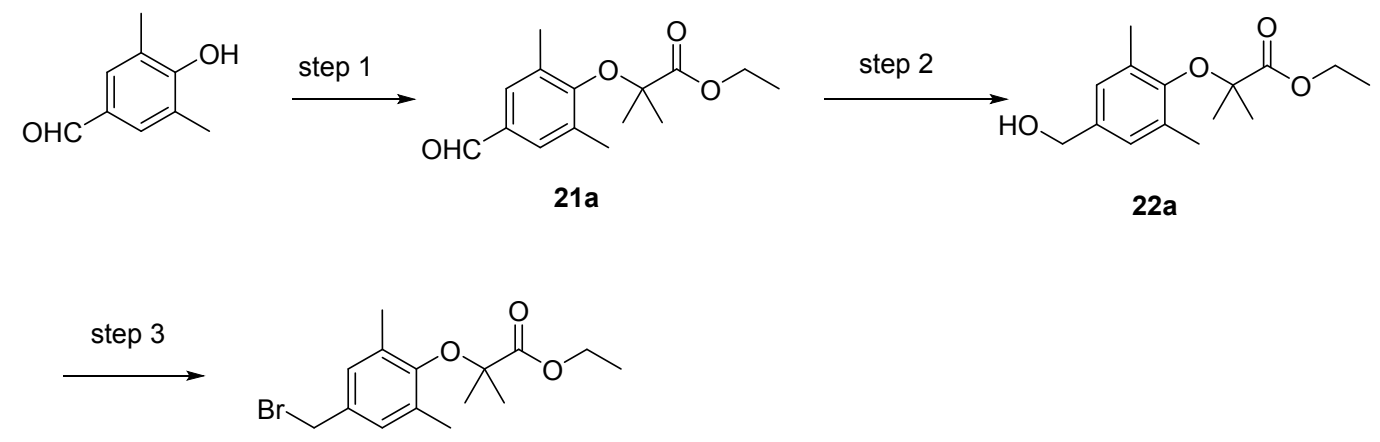

$17 a$

Step 1: A solution of 4-hydroxy-3,5-dimethylbenzaldehyde $(21.0 \mathrm{~g}, 140 \mathrm{mmol})$ in $\mathrm{CH}_{3} \mathrm{CN}(200 \mathrm{~mL})$ was added ethyl-2-bromoisobutyrate $(75.0 \mathrm{~mL}, 420 \mathrm{mmol})$, and $\mathrm{Cs}_{2} \mathrm{CO}_{3}(114.0 \mathrm{~g}, 350 \mathrm{mmol})$. The mixture was heated at $80^{\circ} \mathrm{C}$ overnight. The mixture was concentrated under reduced pressure. Water $(200 \mathrm{~mL})$ was added to the residue. The mixture was extracted with EA $(200 \mathrm{~mL}$ x 3$)$ and washed with $1 \mathrm{~N} \mathrm{NaOH}(100 \mathrm{~mL}$ $\mathrm{x} 3)$ and brine $(100 \mathrm{~mL})$. The organic phase was dried with anhydrous $\mathrm{Mg}_{2} \mathrm{SO}_{4}$ and concentrated under reduced pressure to $21 \mathrm{a}(22.2 \mathrm{~g}, 60 \%)$.

Step 2: A solution of 21a $(3.7 \mathrm{~g}, 13.9 \mathrm{mmol})$ in ethanol $(20 \mathrm{~mL})$ was added sodium borohydride $(0.3 \mathrm{~g}, 7.5 \mathrm{mmol})$ at $0{ }^{\circ} \mathrm{C}$. The mixture was stirred at room temperature overnight. The mixture was diluted with water $(20 \mathrm{~mL})$ and stirred for 30 minutes. The mixture was extracted with EA $(50 \mathrm{~mL} \times 3)$ and washed with brine $(25 \mathrm{~mL})$. The organic phase was concentrated under reduced pressure to $\mathbf{2 2 a}(3.3 \mathrm{~g}, 90 \%)$.

Step 3: A solution of 22a $(2.7 \mathrm{~g}, 10 \mathrm{mmol})$ in dichloromethane $(15 \mathrm{~mL})$ was added carbon tetrabromide $(5.0 \mathrm{~g}, 15 \mathrm{mmol})$ and triphenylphosphine $(4.7 \mathrm{~g}, 14 \mathrm{mmol})$ at $0{ }^{\circ} \mathrm{C}$. The mixture was stirred at room temperature overnight. The mixture was concentrated under reduced pressure. The residue was purified by silica gel column chromatography $(\mathrm{EA} / \mathrm{PE}=1: 20)$ to give desired 17a (1.64 g, 50\%): ${ }^{1} \mathrm{H}$ NMR $(300 \mathrm{MHz}, \mathrm{CDCl} 3) \delta 7.03$ (s, 2H), $4.43(\mathrm{~s}, 2 \mathrm{H}), 4.30(\mathrm{q}, J=7.1 \mathrm{~Hz}, 2 \mathrm{H}), 2.21(\mathrm{~s}, 6 \mathrm{H}), 1.49$ (s, 6H), 1.37 (t, $J=7.1$ $\mathrm{Hz}, 3 \mathrm{H})$. 


\section{Synthetic procedure for $17 \mathrm{~b}$}

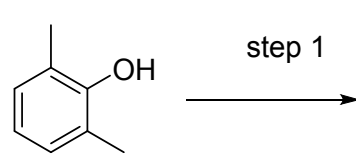<smiles>CCOC(=O)C(C)(C)Oc1c(C)cccc1C</smiles>

$21 b$<smiles>CCOC(=O)C(C)(C)Oc1c(C)cc(C(=O)CBr)cc1C</smiles>

$22 b$<smiles>CCOC(=O)C(C)(C)Oc1c(C)cc(CCBr)cc1C</smiles>

$17 \mathrm{~b}$

Step 1: A solution of 2,6-dimethylphenol (1.2 g, $10 \mathrm{mmol})$ in $\mathrm{CH}_{3} \mathrm{CN}$ (15 mL) was added ethyl 2-bromoisobutyrate $(3.4 \mathrm{~mL}, 30 \mathrm{mmol})$, and $\mathrm{Cs}_{2} \mathrm{CO}_{3}(8.1 \mathrm{~g}, 25 \mathrm{mmol})$. The mixture was heated at $80{ }^{\circ} \mathrm{C}$ overnight. The mixture was concentrated under reduced pressure. Water was added to the residue. The mixture was extracted with EA $(50 \mathrm{~mL}$ $\mathrm{x} 3)$ and washed with $1 \mathrm{~N} \mathrm{NaOH}(20 \mathrm{~mL}$ x 3$)$ and brine $(20 \mathrm{~mL})$. The organic phase was dried with anhydrous $\mathrm{Mg}_{2} \mathrm{SO}_{4}$ and concentrated under reduced pressure to $\mathbf{2 1 b}$ (1.2 g, $51 \%)$.

Step 2: A solution of aluminum chloride (3.2 g, $24 \mathrm{mmol})$ in dichloromethane was added bromoacetyl bromide $(2.1 \mathrm{~mL}, 24 \mathrm{mmol})$ at $0{ }^{\circ} \mathrm{C}$ under a nitrogen atmosphere. The mixture was stirred for 1 hour. The mixture was added $\mathbf{2 1 b}(1.9 \mathrm{~g}, 8 \mathrm{mmol})$ at $0{ }^{\circ} \mathrm{C}$. The mixture was stirred at room temperature overnight. The mixture was concentrated under reduced pressure. The residue was diluted with water $(20 \mathrm{~mL})$ and extracted with EA $(20 \mathrm{~mL} \times 3)$ and washed with brine $(20 \mathrm{~mL})$. The organic phase was concentrated under reduced pressure to $\mathbf{2 2 b}(2.3 \mathrm{~g}, 82 \%)$.

Step 3: A solution of $\mathbf{2 2 b}(1.8 \mathrm{~g}, 5 \mathrm{mmol})$ in trifluoroacetic acid $(15 \mathrm{~mL})$ was added triethylsilane $(1.0 \mathrm{~mL}, 7.5 \mathrm{mmol})$ at room temperature. The mixture was heated at $70{ }^{\circ} \mathrm{C}$ overnight. The mixture was diluted with water $(20 \mathrm{~mL})$ at $0{ }^{\circ} \mathrm{C}$ and stirred at room temperature for 10 minutes. The mixture was concentrated under reduced pressure. The residue was extracted with EA $(20 \mathrm{~mL} \times 3)$ and washed with saturated sodium bicarbonate $(20 \mathrm{~mL})$ and brine $(20 \mathrm{~mL})$. The organic phase was concentrated under reduced pressure to $\mathbf{1 7 b}(1.4 \mathrm{~g}, 85 \%):{ }^{1} \mathrm{H}$ NMR $(300 \mathrm{MHz}, \mathrm{CDCl} 3) \delta 6.82(\mathrm{~s}, 2 \mathrm{H}), 4.30$ 
(q, $J=7.1 \mathrm{~Hz}, 2 \mathrm{H}), 3.53(\mathrm{t}, J=7.8 \mathrm{~Hz}, 2 \mathrm{H}), 3.05(\mathrm{t}, J=7.8 \mathrm{~Hz}, 2 \mathrm{H}), 2.20(\mathrm{~s}, 6 \mathrm{H}), 1.48$ (s, 6H), $1.37(\mathrm{t}, J=7.1 \mathrm{~Hz}, 3 \mathrm{H})$.

\section{Synthetic procedure for $17 \mathrm{c}$}
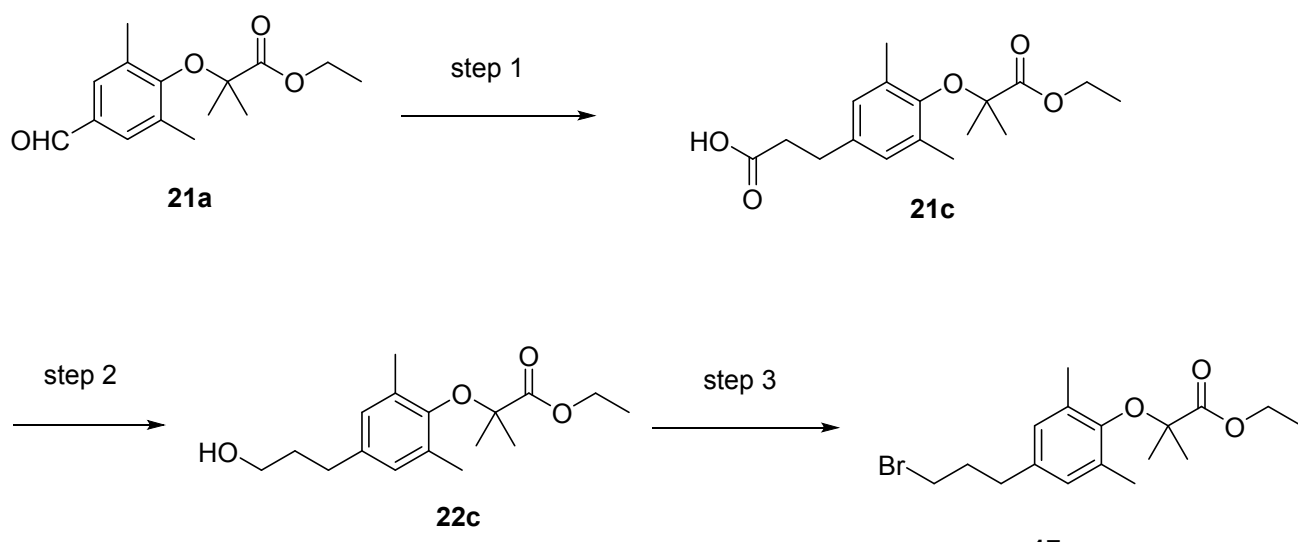

$17 c$

Step 1: A solution of 21a (0.5 g, $2.25 \mathrm{mmol})$ in DMF (5 mL) was added 2,2-dimethyl1,3-dioxane-4,6-dione $(0.5 \mathrm{~g}, 3.38 \mathrm{mmol})$ and triethylamine $(0.4 \mathrm{~mL}, 2.7 \mathrm{mmol})$ at room temperature. The mixture was added formic acid at $0{ }^{\circ} \mathrm{C}$ and stirred for 5 minutes. The mixture was heated at $100{ }^{\circ} \mathrm{C}$ overnight. The mixture was diluted with water $(20$ $\mathrm{mL})$ and extracted with EA $(50 \mathrm{~mL} \times 3)$ and washed with brine $(20 \mathrm{~mL})$. The organic phase was dried with anhydrous $\mathrm{MgSO}_{4}$ and concentrated under reduced pressure to 21c $(0.67 \mathrm{~g}, 96 \%)$.

Step 2: A solution of 21c $(0.5 \mathrm{~g}, 1.5 \mathrm{mmol})$ in tetrahydrofuran $(5 \mathrm{~mL})$ was added borane-tetrahydrofuran complex $(1 \mathrm{~mL}, 1 \mathrm{mmol})$ at $0{ }^{\circ} \mathrm{C}$. The mixture was stirred overnight. The mixture was diluted with water $(10 \mathrm{~mL})$ and stirred for 30 minutes. The mixture was extracted with EA $(20 \mathrm{~mL}$ x 3$)$ and washed with brine $(20 \mathrm{~mL})$. The organic phase was concentrated under reduced pressure to $22 \mathrm{c}(0.38 \mathrm{~g}, 85 \%)$.

Step 3: A solution of 22c $(0.2 \mathrm{~g}, 1 \mathrm{mmol})$ in dichloromethane $(5 \mathrm{~mL})$ was added carbon tetrabromide $(0.5 \mathrm{~g}, 1.5 \mathrm{mmol})$ and triphenylphosphine $(0.5 \mathrm{~g}, 1.4 \mathrm{mmol})$ at $0{ }^{\circ} \mathrm{C}$. The mixture was stirred at room temperature overnight. The mixture was concentrated under reduced pressure. The residue was purified by silica gel column chromatography (EA/PE=1:20) to give desired 17c $(0.3 \mathrm{~g}, 91 \%):{ }^{1} \mathrm{H} \mathrm{NMR}\left(300 \mathrm{MHz}, \mathrm{CDCl}_{3}\right) \delta 6.80(\mathrm{~s}$, 2H), 4.30 (q, $J=7.1 \mathrm{~Hz}, 2 \mathrm{H}), 3.40(\mathrm{t}, J=6.6 \mathrm{~Hz}, 2 \mathrm{H}), 2.66$ (t, $J=7.3 \mathrm{~Hz}, 2 \mathrm{H}), 2.19$ (s, 
6H), $2.10(\mathrm{dd}, J=6.6,7.3 \mathrm{~Hz}, 2 \mathrm{H}), 1.48(\mathrm{~s}, 6 \mathrm{H}), 1.37(\mathrm{t}, J=7.1 \mathrm{~Hz}, 3 \mathrm{H})$.

\section{General synthetic procedure for $17 \mathrm{~d}-171$}

The preparation of $\mathbf{1 7 d - 1 7 l}$ is similar to the procedure of $\mathbf{1 7 a}$.

\section{Synthetic procedure for $17 \mathrm{~m}$}
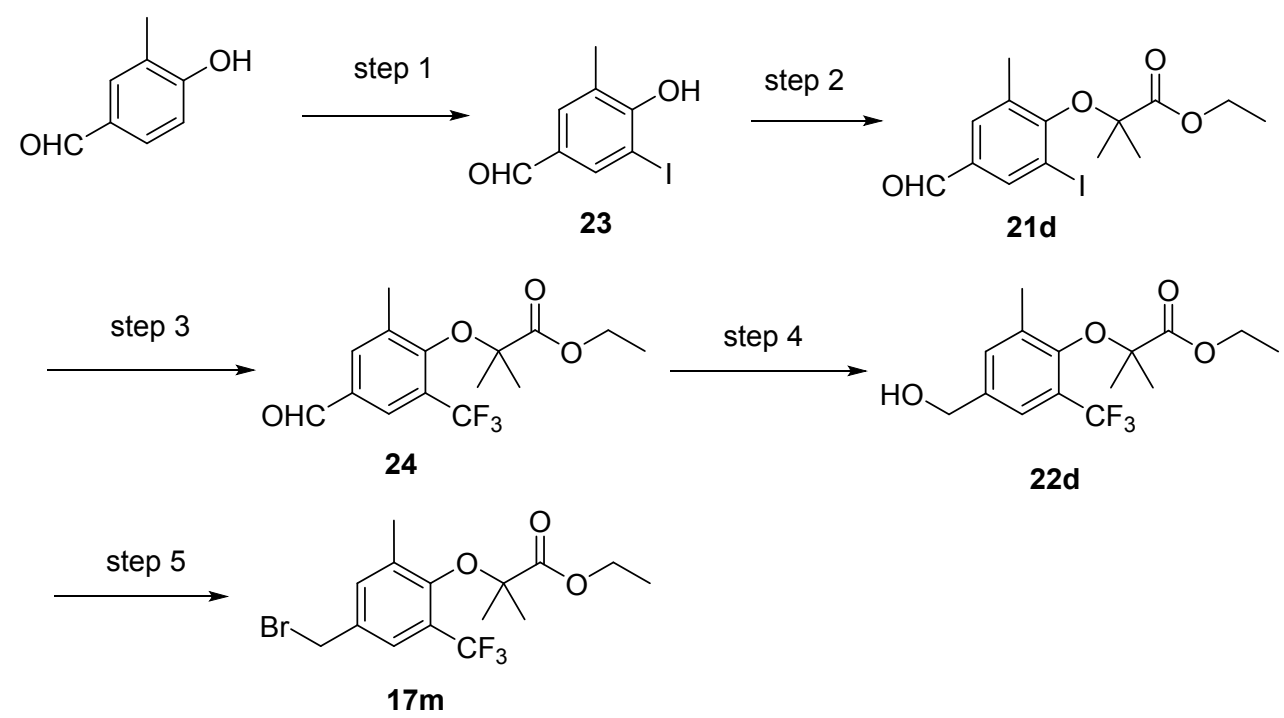

22d

Step 1: A solution of 4-hydroxy-3-methylbenzaldehyde (2.6 g, $15 \mathrm{mmol})$ in methanol $(25 \mathrm{~mL})$ was added $\mathrm{NaOH}(1.2 \mathrm{~g}, 30 \mathrm{mmol})$ and iodine $(4.9 \mathrm{~g}, 19.5 \mathrm{mmol})$. The mixture was stirred at room temperature overnight. The mixture was neutralized with $2 \mathrm{~N} \mathrm{HCl}$ (15 mmol). The mixture was extracted with EA (50 mL x 3) and washed with brine (20 $\mathrm{mL}$ ). The organic phase was dried with anhydrous $\mathrm{MgSO} 4$ and concentrated under reduced pressure to $23(3.4 \mathrm{~g}, 86 \%)$.

Step 2: Compound 21d was prepared in a manner similar to that described for 21a (1.9 g, 52\%).

Step 3: A solution of 21d (1.9 g, $5 \mathrm{mmol})$ in DMF (10 mL) was added methyl 2,2difluoro-2-(fluorosulfonyl)acetate $(1.8 \mathrm{~mL}, 15 \mathrm{mmol})$ and cupric chloride (Cat.) under a nitrogen atmosphere at room temperature. The mixture was stirred at $110^{\circ} \mathrm{C}$ overnight. The mixture was extracted with EA (20 mL x 3) and washed with brine $(20 \mathrm{~mL})$. The organic phase was dried with anhydrous $\mathrm{Mg}_{2} \mathrm{SO}_{4}$ and concentrated under reduced pressure to $24(0.84 \mathrm{~g}, 53 \%)$.

Step 4: compound 22d was prepared in a manner similar to that described for 22a $(0.68$ 
g, 84\%).

Step 5: Compound $\mathbf{1 7} \mathrm{m}$ was prepared in a manner similar to that described for $\mathbf{1 7 a}$ $(0.33 \mathrm{~g}, 86 \%)$.

\section{Synthetic procedure for $17 n$}

The preparation of $\mathbf{1 7 n}$ is similar to the procedure of $\mathbf{1 7 a}$.

Synthetic procedure for 170<smiles>Cc1cc(Br)cc(C)c1O</smiles>

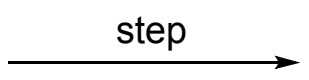<smiles>CCOC(=O)C(C)(C)Oc1c(C)cc(Br)cc1C</smiles>

170

Step: A solution of 4-bromo-2,6-dimethylphenol (2.0 g, $10 \mathrm{mmol})$ in DMF (10 mL) was added ethyl-2-bromoisobutyrate $(7.4 \mathrm{~mL}, 30 \mathrm{mmol})$, and $\mathrm{Cs}_{2} \mathrm{CO}_{3}(8.1 \mathrm{~g}, 25 \mathrm{mmol})$. The mixture was heated at $80{ }^{\circ} \mathrm{C}$ overnight. The mixture was concentrated under reduced pressure. Water $(100 \mathrm{~mL})$ was added to the residue, extracted with EA (30 $\mathrm{mL}$ ). The organic phase was dried with anhydrous $\mathrm{Mg}_{2} \mathrm{SO}_{4}$ and concentrated under reduced pressure. The residue was purified by silica gel column chromatography $(\mathrm{EA} / \mathrm{PE}=1: 50)$ to give desired $\mathbf{1 7 0}(2.3 \mathrm{~g}, 73 \%)$.

\section{Synthetic procedure for $18 a$}<smiles>O=c1[nH]ncn1-c1ccc(C(F)(F)F)cc1</smiles>

$13 a$

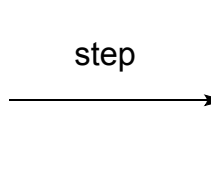<smiles>O=c1n(-c2ccc(C(F)(F)F)cc2)cnn1CO</smiles>

$18 a$

Step: A solution of 13a $(2.1 \mathrm{~g}, 8.5 \mathrm{mmol})$ in $\mathrm{CH}_{3} \mathrm{CN}(15 \mathrm{~mL})$ was added paraformaldehyde (1.3 g, $42.5 \mathrm{mmol})$ and acetic acid (Cat.). The mixture was heated at $60{ }^{\circ} \mathrm{C}$ overnight. The mixture was concentrated under reduced pressure. The residue was purified by silica gel column chromatography $(\mathrm{EA} / \mathrm{PE}=1: 2)$ to give $\mathbf{1 8 a}(1.4 \mathrm{~g}$, $62 \%)$.

\section{Synthetic procedure for $20 \mathrm{a}$}


<smiles>CCOC(=O)C(C)(C)Oc1c(C)cc(C=O)cc1C</smiles>

$21 a$<smiles>CCOC(=O)C(C)(C)Oc1c(C)cc(O)cc1C</smiles>

20a

Step: A solution of $21 \mathrm{a}(1.4 \mathrm{~g}, 10 \mathrm{mmol})$ in dichloromethane $(15 \mathrm{~mL})$ was added 3 chloroperbenzoic acid $(3.5 \mathrm{~g}, 20 \mathrm{mmol})$ and p-toluenesulfonic acid (Cat.) at $0{ }^{\circ} \mathrm{C}$. The mixture was stirred at room temperature overnight. The mixture was filtered and the filtrate was washed with saturated sodium bicarbonate $(50 \mathrm{~mL} \mathrm{x} 3)$ and brine $(30 \mathrm{~mL})$. The organic phase was dried with anhydrous $\mathrm{Mg}_{2} \mathrm{SO}_{4}$ and concentrated under reduced pressure.

The residue was added ethanol and sodium ethoxide $(0.8 \mathrm{~g}, 11 \mathrm{mmol})$ dissolved in ethanol $(10 \mathrm{~mL})$ under a nitrogen atmosphere. The mixture was stirred at room temperature overnight. The mixture was adjusted to $\mathrm{pH} 3$ with $1 \mathrm{~N} \mathrm{HCl}(11 \mathrm{~mL})$ and concentrated under reduced pressure. The residue was diluted with water $(10 \mathrm{~mL})$ and extracted with EA (20 mL x 3) and washed with brine $(20 \mathrm{~mL})$. The organic phase was concentrated under reduced pressure. The residue was purified by silica gel column chromatography $(\mathrm{EA} / \mathrm{PE}=1: 3)$ to give desired 20a $(0.76 \mathrm{~g})$ in $30 \%$ yield.

\section{Synthetic procedure for $20 \mathrm{~b}$}

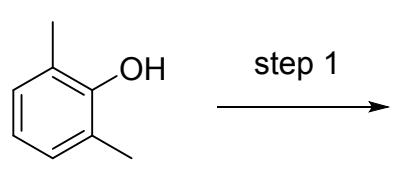

$\stackrel{\text { step } 3}{\longrightarrow}$<smiles>Cc1cc(S(N)(=O)=O)cc(C)c1O</smiles>

25<smiles>CCOC(=O)C(C)(C)Oc1c(C)cc(S)cc1C</smiles>

$20 \mathrm{~b}$

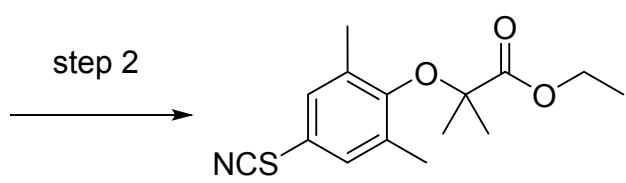

26

Step 1: A solution of 2,6-dimethylphenol (1.2 g, $10 \mathrm{mmol})$ in dichloromethane $(25 \mathrm{~mL})$ was added ammonium thiocyanate $(1.1 \mathrm{~g}, 15 \mathrm{mmol})$ and potassium persulfate $(5.4 \mathrm{~g}, 20$ mmol) at room temperature. The mixture was stirred at room temperature overnight. The mixture was concentrated under reduced pressure to $25(0.74 \mathrm{~g}, 41 \%)$. 
Step 2: A solution of $25(1.4 \mathrm{~g}, 8 \mathrm{mmol})$ in $\mathrm{CH}_{3} \mathrm{CN}(15 \mathrm{~mL})$ was added ethyl 2bromoisobutyrate $(2.7 \mathrm{~mL}, 24 \mathrm{mmol})$, and $\mathrm{Cs}_{2} \mathrm{CO}_{3}(6.5 \mathrm{~g}, 20 \mathrm{mmol})$. The mixture was heated at $80^{\circ} \mathrm{C}$ overnight. The mixture was concentrated under reduced pressure. Water $(20 \mathrm{~mL})$ was added to the residue. The mixture was extracted with EA $(25 \mathrm{~mL} \times 3)$ and washed with $1 \mathrm{~N} \mathrm{NaOH}(20 \mathrm{~mL} \times 3)$ and brine $(25 \mathrm{~mL})$. The organic phase was dried with anhydrous $\mathrm{Mg}_{2} \mathrm{SO}_{4}$ and concentrated under reduced pressure to 26 (0.59 g, 25\%). Step 3: A solution of $26(1.4 \mathrm{~g}, 5 \mathrm{mmol})$ in absolute ethanol $(15 \mathrm{~mL})$ was added $6 \mathrm{~N}$ $\mathrm{HCl}(1.25 \mathrm{~mL}, 7.5 \mathrm{mmol})$, and zinc powder (1.6 g, $25 \mathrm{mmol})$ at room temperature. The mixture was heated at $75^{\circ} \mathrm{C}$ for 8 hours. The mixture was concentrated under reduced pressure. The residue was purified by silica gel column chromatography $(\mathrm{EA} / \mathrm{PE}=1: 20)$ to give desired $\mathbf{2 0 b}(1.1 \mathrm{~g}, 81 \%)$. 
Procedures for preparation of the key GFT-505, IVA-337 and compound 8

Synthetic procedure for 1 (GFT-505)<smiles>CSc1ccc(C(=O)/C=C/c2cc(C)c(OC(C)(C)C(=O)O)c([Se][Se])c2)cc1</smiles>

1 (GFT-505)

(E)-2-(2,6-dimethyl-4-(3-(4-(methylthio)phenyl)-3-oxoprop-1-en-1-yl)phenoxy)-2methylpropanoic acid (1): 1 (GFT-505) is synthesized as reported (CN106674069): ${ }^{1} \mathrm{H}$ NMR $\left(300 \mathrm{MHz}, \mathrm{DMSO}-d_{6}\right) \delta 12.92(\mathrm{~s}, 1 \mathrm{H}), 8.10(\mathrm{~d}, \mathrm{~J}=8.4 \mathrm{~Hz}, 2 \mathrm{H}), 7.81(\mathrm{~d}, J=$ 15.6 Hz, 1H), $7.62(\mathrm{~d}, J=15.7 \mathrm{~Hz}, 1 \mathrm{H}), 7.57(\mathrm{~s}, 2 \mathrm{H}), 7.41$ (d, $J=8.4 \mathrm{~Hz}, 2 \mathrm{H}), 2.57(\mathrm{~s}$, $3 \mathrm{H}), 2.23(\mathrm{~s}, 6 \mathrm{H}), 1.40(\mathrm{~s}, 6 \mathrm{H})$. HRMS (ESI): exact mass calculated for $\mathrm{C}_{22} \mathrm{H}_{24} \mathrm{O}_{4} \mathrm{~S}$ $[\mathrm{M}+\mathrm{Na}]^{+}:$407.1293, found: 407.1290. Purity, 97.47\%.

Synthetic procedure for 2 (IVA-337)<smiles>O=C(O)CCCc1cc2cc(Cl)ccc2n1S(=O)(=O)c1ccc([AsH2])cc1</smiles>

4-(1-(benzo[d]thiazol-6-ylsulfonyl)-5-chloro-1H-indol-2-yl)butanoic acid

(2) : 2 (IVA-337) is synthesized as reported ( $\mathrm{J}$ Med Chem. 2018, 61, 2246-2265.): ${ }^{1} \mathrm{H}$ NMR (300 MHz, DMSO- $\left.d_{6}\right) \delta 12.13(\mathrm{~s}, 1 \mathrm{H}), 9.65(\mathrm{~s}, 1 \mathrm{H}), 8.98(\mathrm{~s}, 1 \mathrm{H}), 8.20(\mathrm{~d}, J=8.7$ $\mathrm{Hz}, 1 \mathrm{H}), 8.09$ (d, $J=8.9 \mathrm{~Hz}, 1 \mathrm{H}), 7.84$ (dd, 1H), 7.56 (s, 1H), 7.31 (dd, $J=8.9,1.6 \mathrm{~Hz}$, 1H), $6.61(\mathrm{~s}, 1 \mathrm{H}), 3.09(\mathrm{t}, J=7.4 \mathrm{~Hz}, 2 \mathrm{H}), 2.36(\mathrm{t}, J=7.2 \mathrm{~Hz}, 2 \mathrm{H}), 1.94(\mathrm{t}, 2 \mathrm{H})$. HRMS (ESI): exact mass calculated for $\mathrm{C}_{19} \mathrm{H}_{15} \mathrm{ClN}_{2} \mathrm{O}_{4} \mathrm{~S}_{2}[\mathrm{M}+\mathrm{Na}]^{+}: 457.0059$, found: 457.0051 . Purity, 98.17\%.

Synthetic procedure for compound 8<smiles>Cc1cc(Cc2cc(-c3ccc(Br)cc3)on2)cc(C)c1OC(C)(C)C(=O)O</smiles> 


\section{2-(4-((5-(4-bromophenyl)isoxazol-3-yl)methyl)-2,6-dimethylphenoxy)-2-}

methylpropanoic acid (8): Compound $\mathbf{8}$ is synthesized as reported (ACS Med Chem Lett. 2019, 10, 1068-1073.): ${ }^{1} \mathrm{H}$ NMR (300 MHz, DMSO-d 6 ) $\delta 12.83$ (s, 1H), 7.80 (d, $J=8.5 \mathrm{~Hz}, 3 \mathrm{H}), 7.72(\mathrm{~d}, J=8.5 \mathrm{~Hz}, 3 \mathrm{H}), 6.96(\mathrm{~s}, 1 \mathrm{H}), 6.94(\mathrm{~s}, 2 \mathrm{H}), 3.90(\mathrm{~s}, 3 \mathrm{H}), 2.14$ (s, 8H), 1.34 (s, 9H). HRMS (ESI): exact mass calculated for $\mathrm{C}_{22} \mathrm{H}_{22} \mathrm{BrNO}_{4}[\mathrm{M}+\mathrm{H}]^{+}$: 444.0810, found: 444.0803. Purity, 97.82\%. 


\section{${ }^{1} \mathrm{H}$ NMR and ${ }^{13} \mathrm{C}$ NMR Spectra of Target Compounds H0-42}

${ }^{1} \mathrm{H}-\mathrm{NMR}$ spectrum (DMSO-d6, $300 \mathrm{MHz}$ ) of $\mathrm{H} 0$

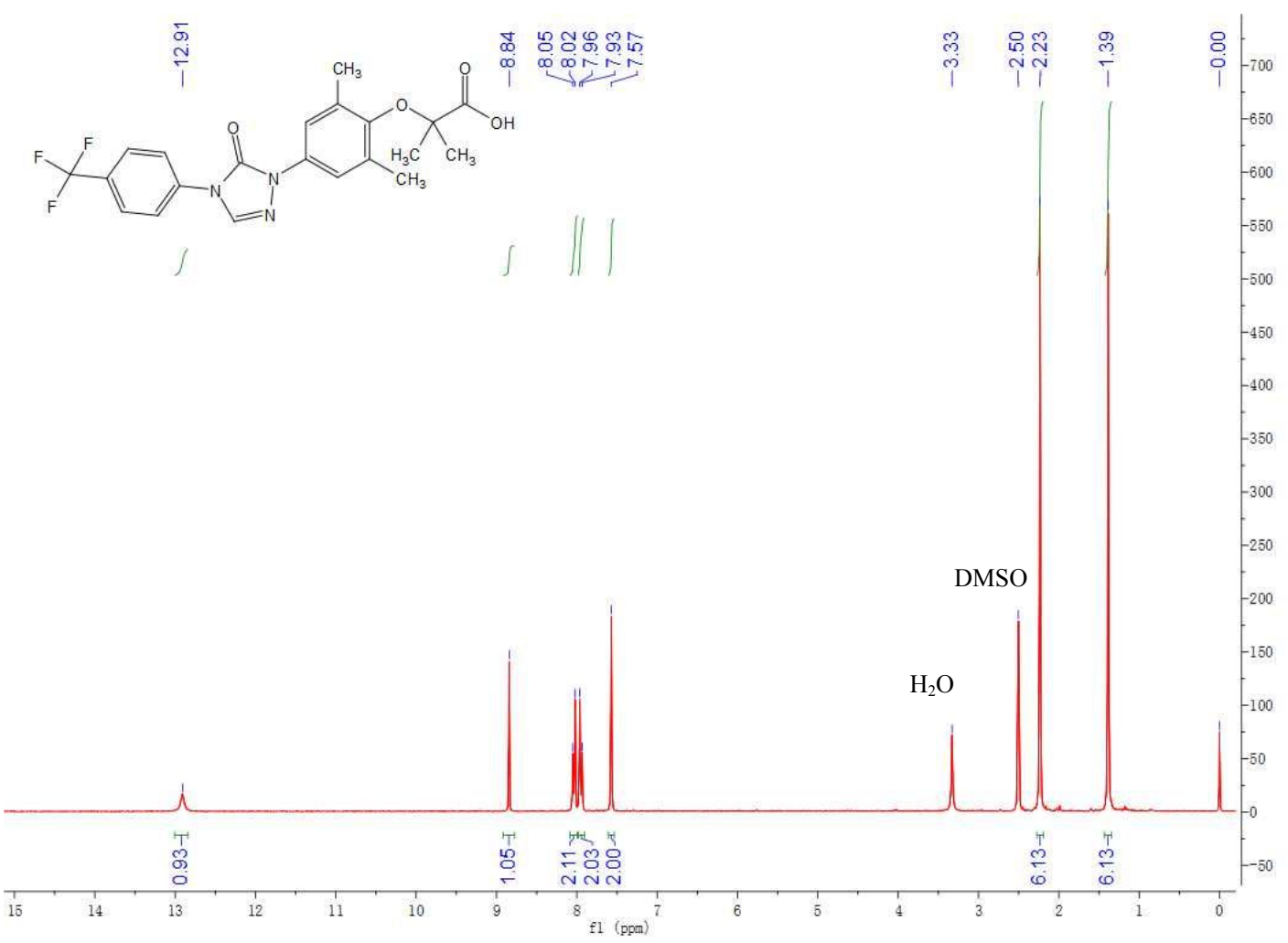

${ }^{13} \mathrm{C}-\mathrm{NMR}$ spectrum (DMSO- $d 6,126 \mathrm{MHz}$ ) of $\mathrm{H0}$

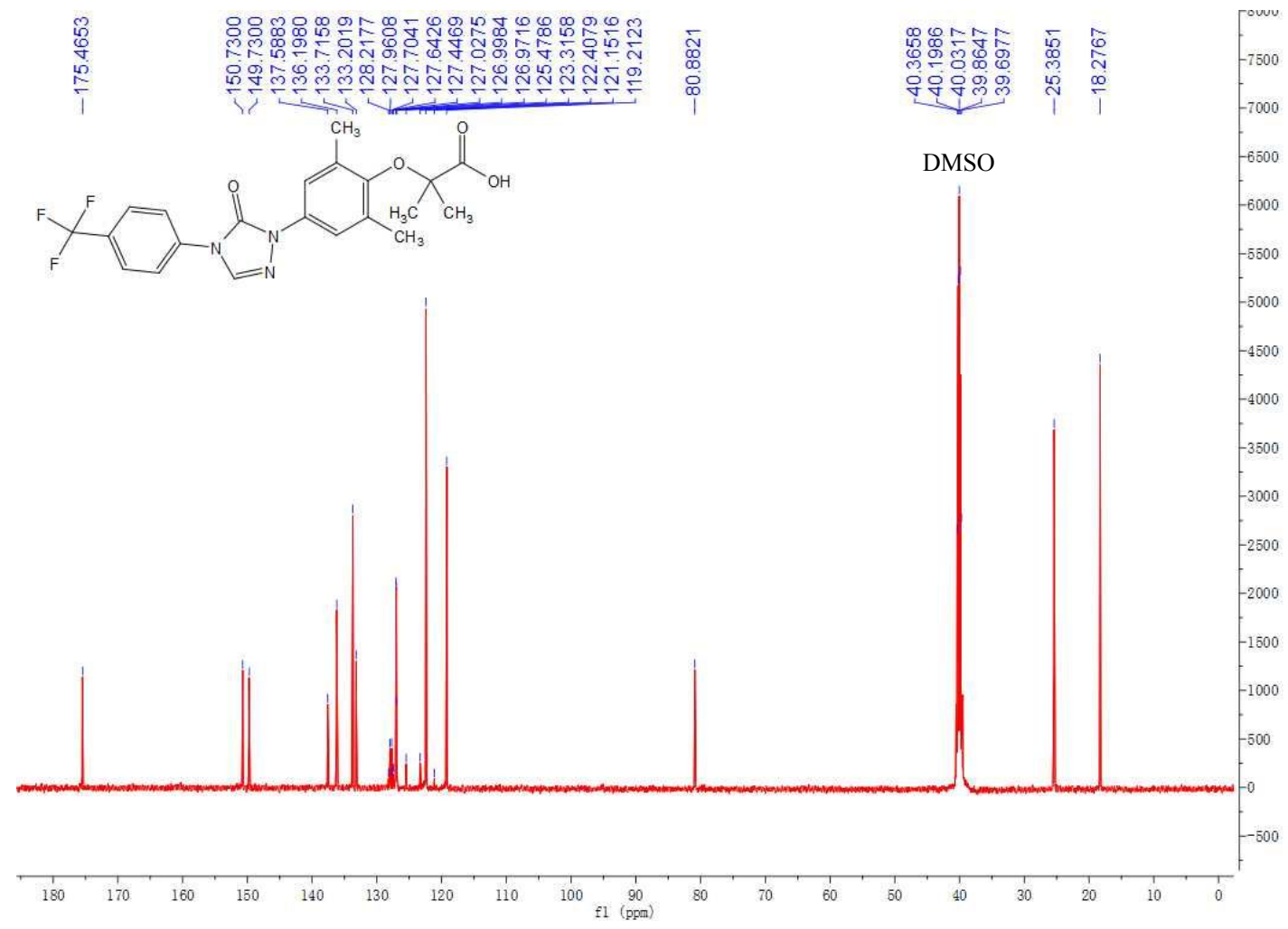


${ }^{1} \mathrm{H}-\mathrm{NMR}$ spectrum (DMSO-d6, $300 \mathrm{MHz}$ ) of $\mathrm{H} 1$

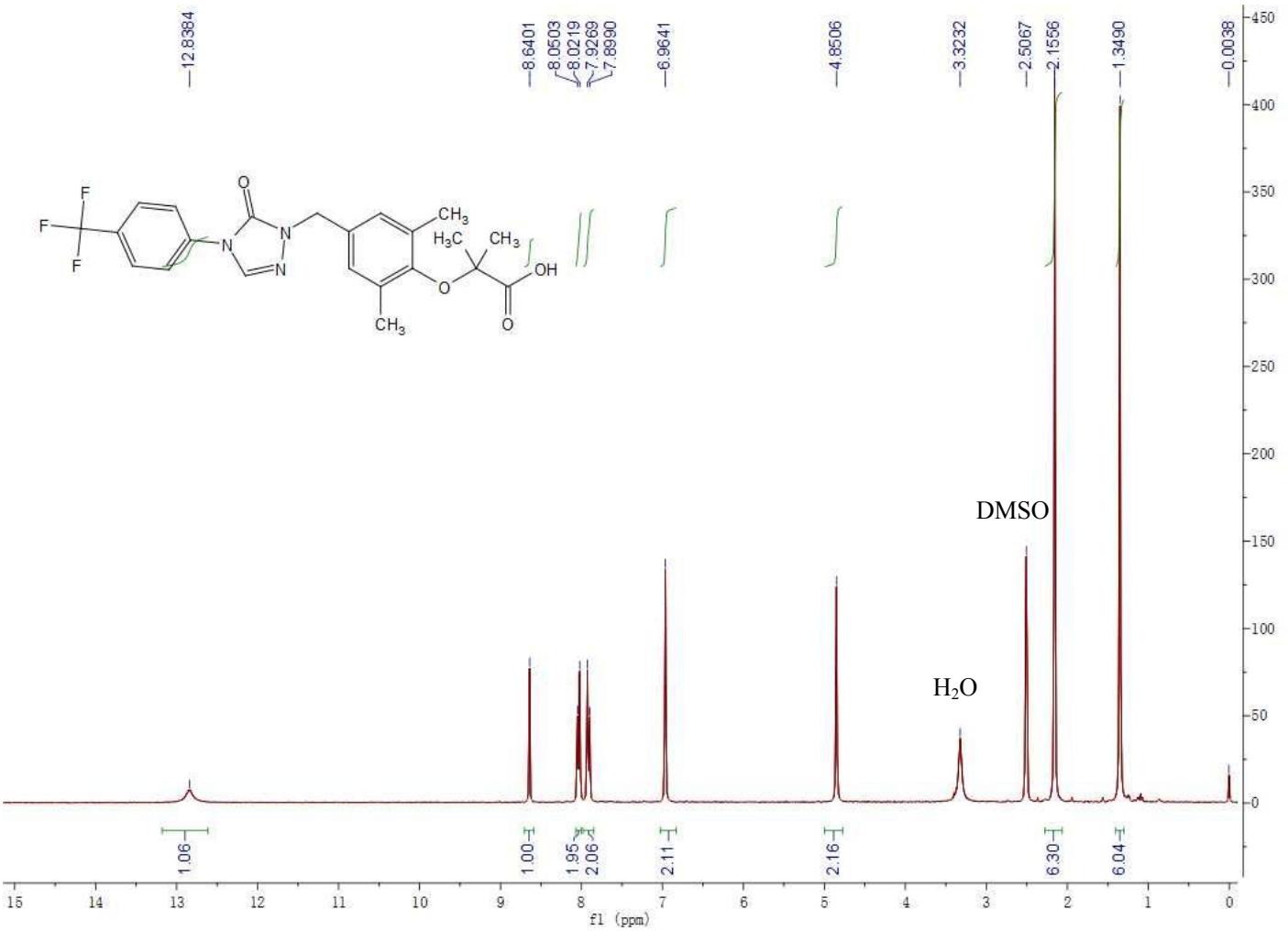

${ }^{13} \mathrm{C}-\mathrm{NMR}$ spectrum (DMSO-d6, $126 \mathrm{MHz}$ ) of $\mathrm{H} 1$

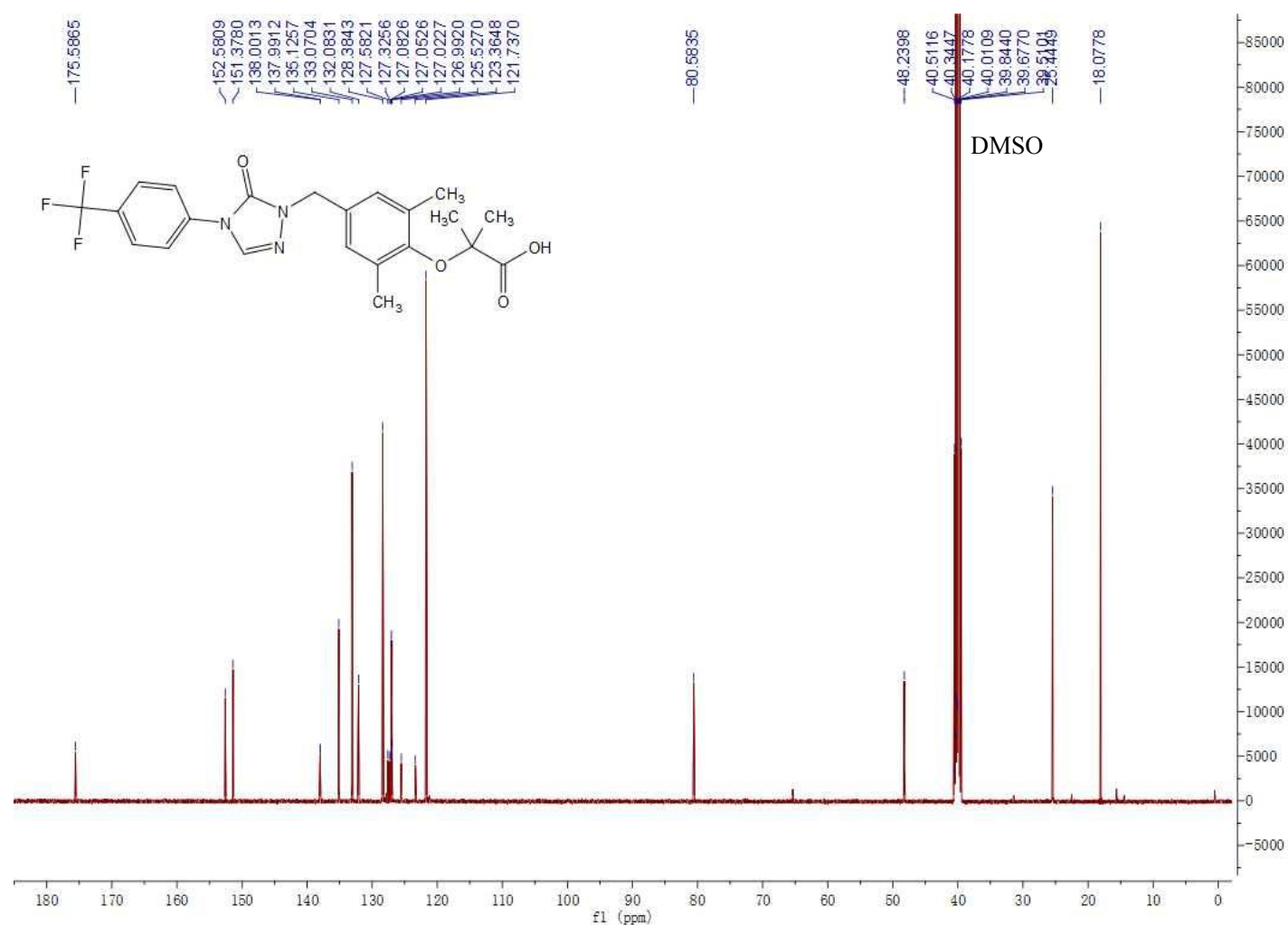


${ }^{1} \mathrm{H}-\mathrm{NMR}$ spectrum (DMSO-d6, $300 \mathrm{MHz}$ ) of $\mathrm{H} 2$

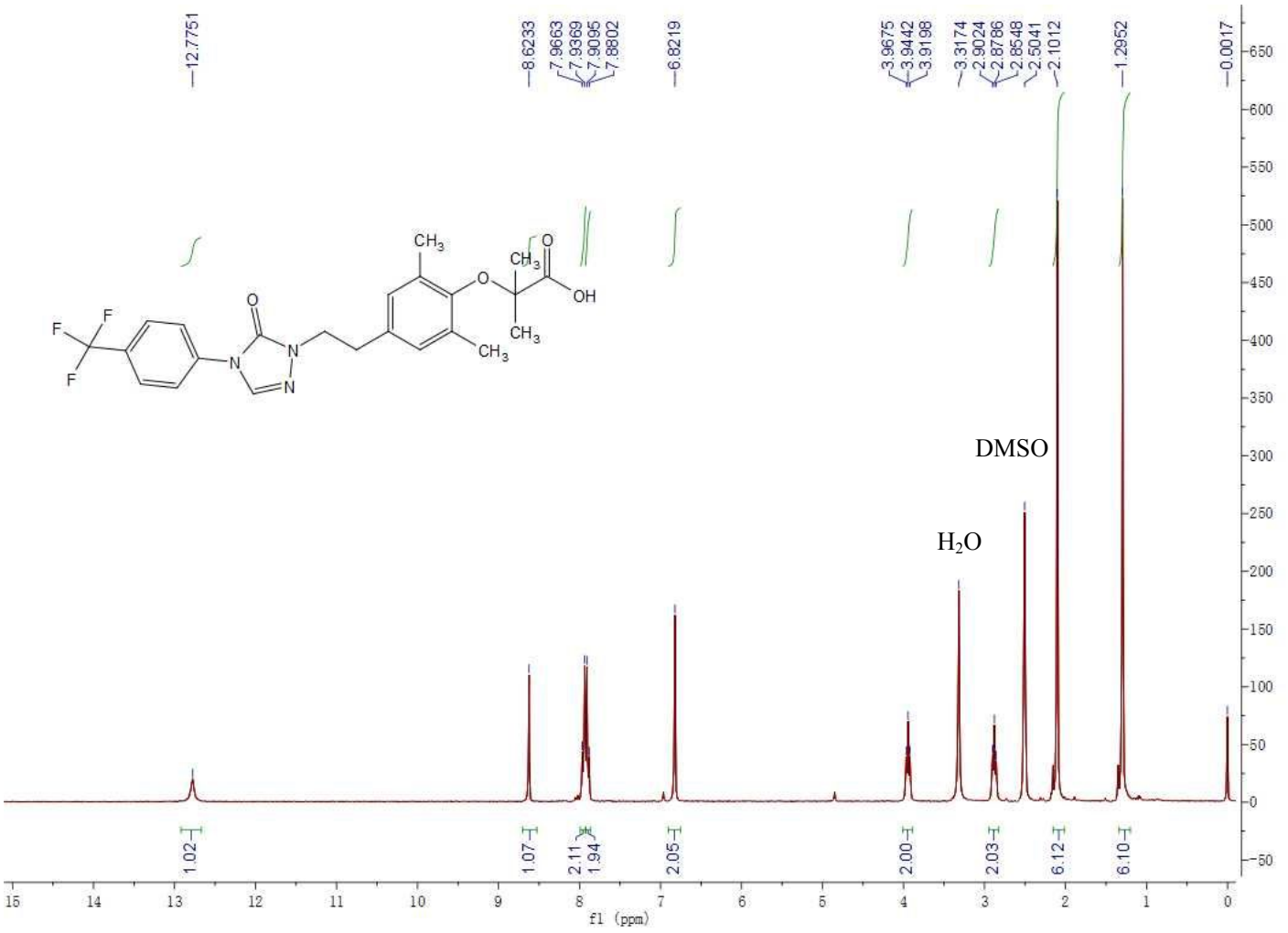

${ }^{13} \mathrm{C}-\mathrm{NMR}$ spectrum (DMSO- $d 6,126 \mathrm{MHz}$ ) of $\mathrm{H} 2$
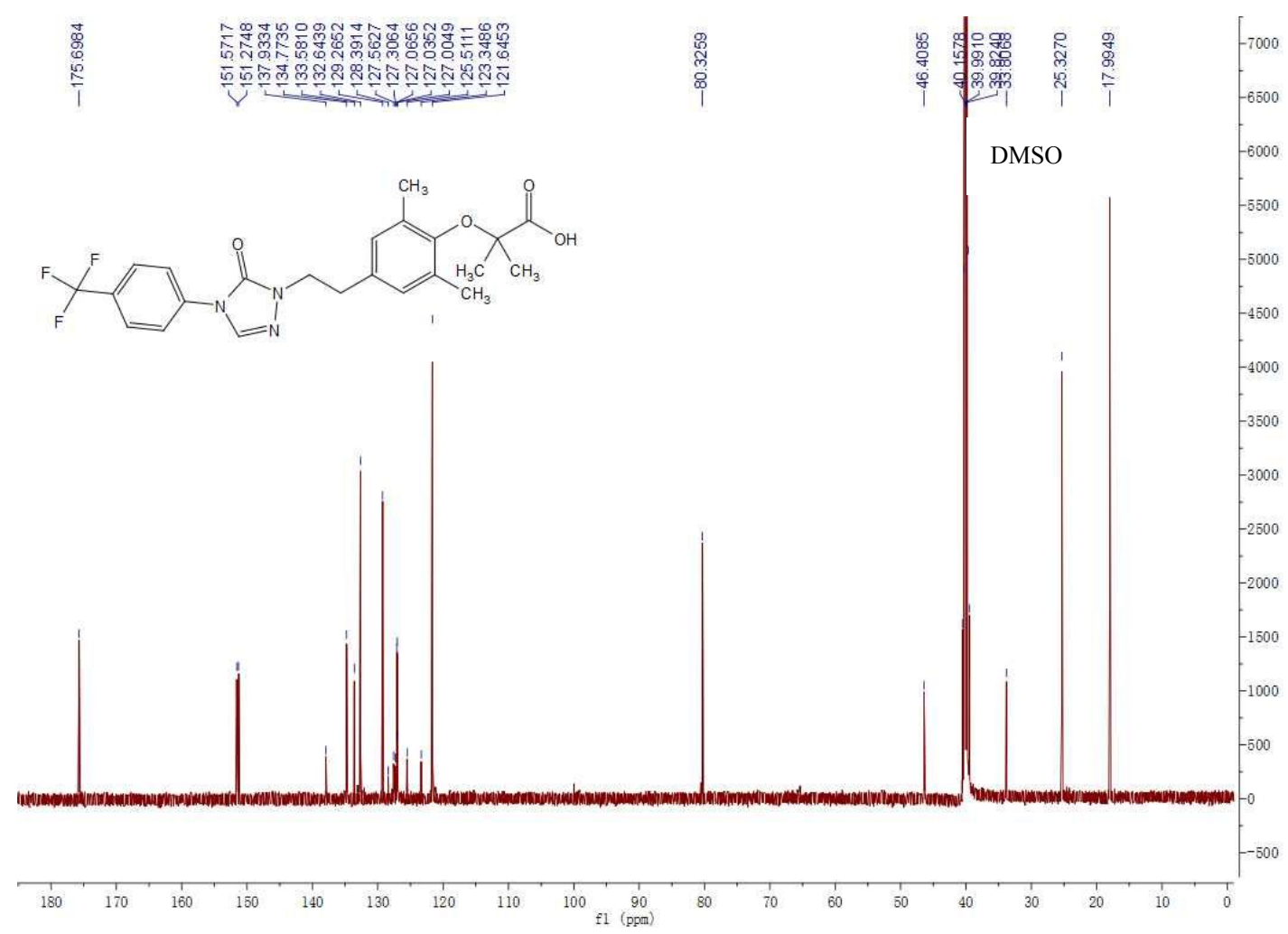
${ }^{1} \mathrm{H}-\mathrm{NMR}$ spectrum (DMSO-d6, $300 \mathrm{MHz}$ ) of $\mathrm{H} 3$

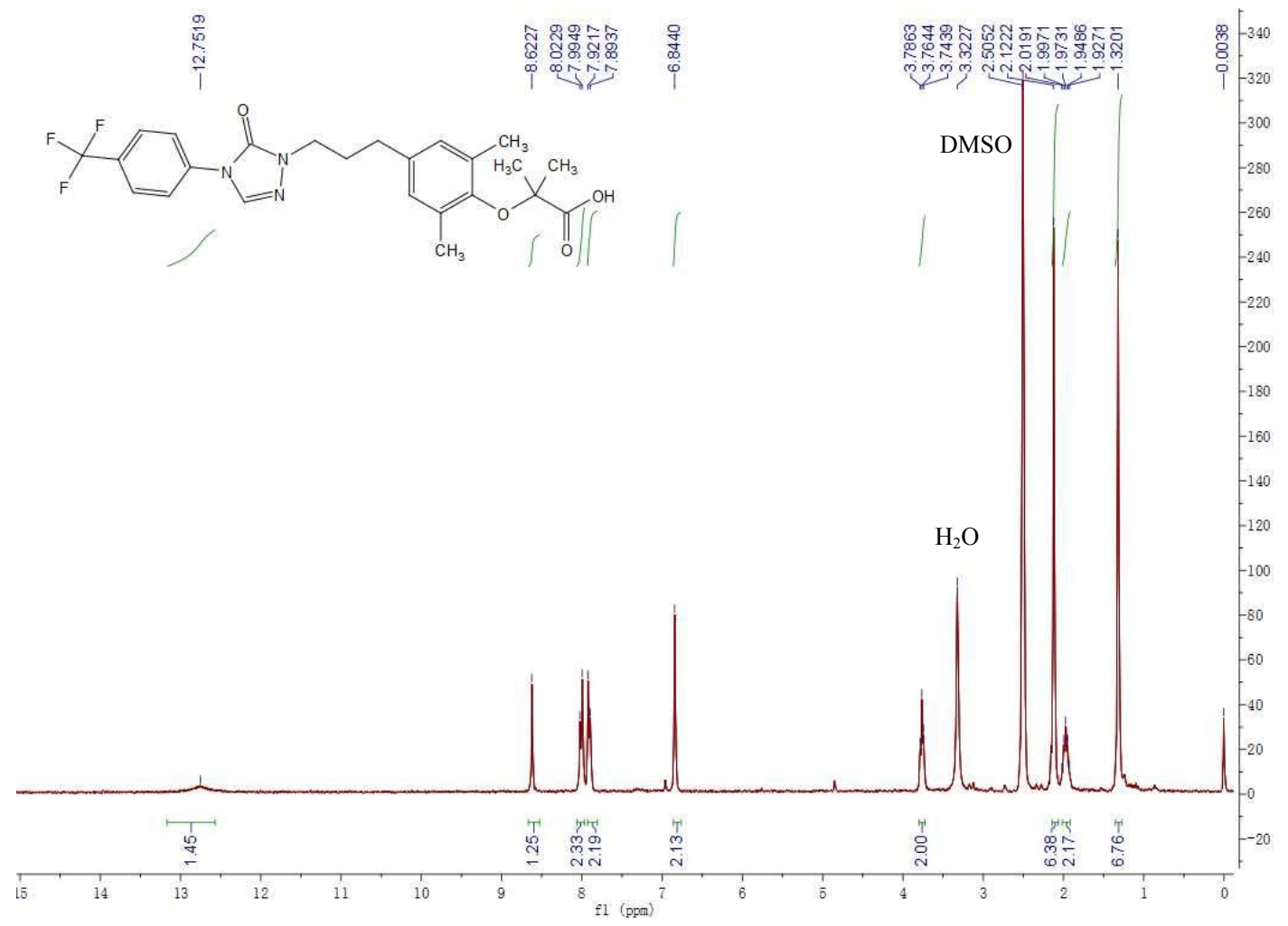

${ }^{13} \mathrm{C}-\mathrm{NMR}$ spectrum (DMSO-d6, $126 \mathrm{MHz}$ ) of $\mathrm{H} 3$

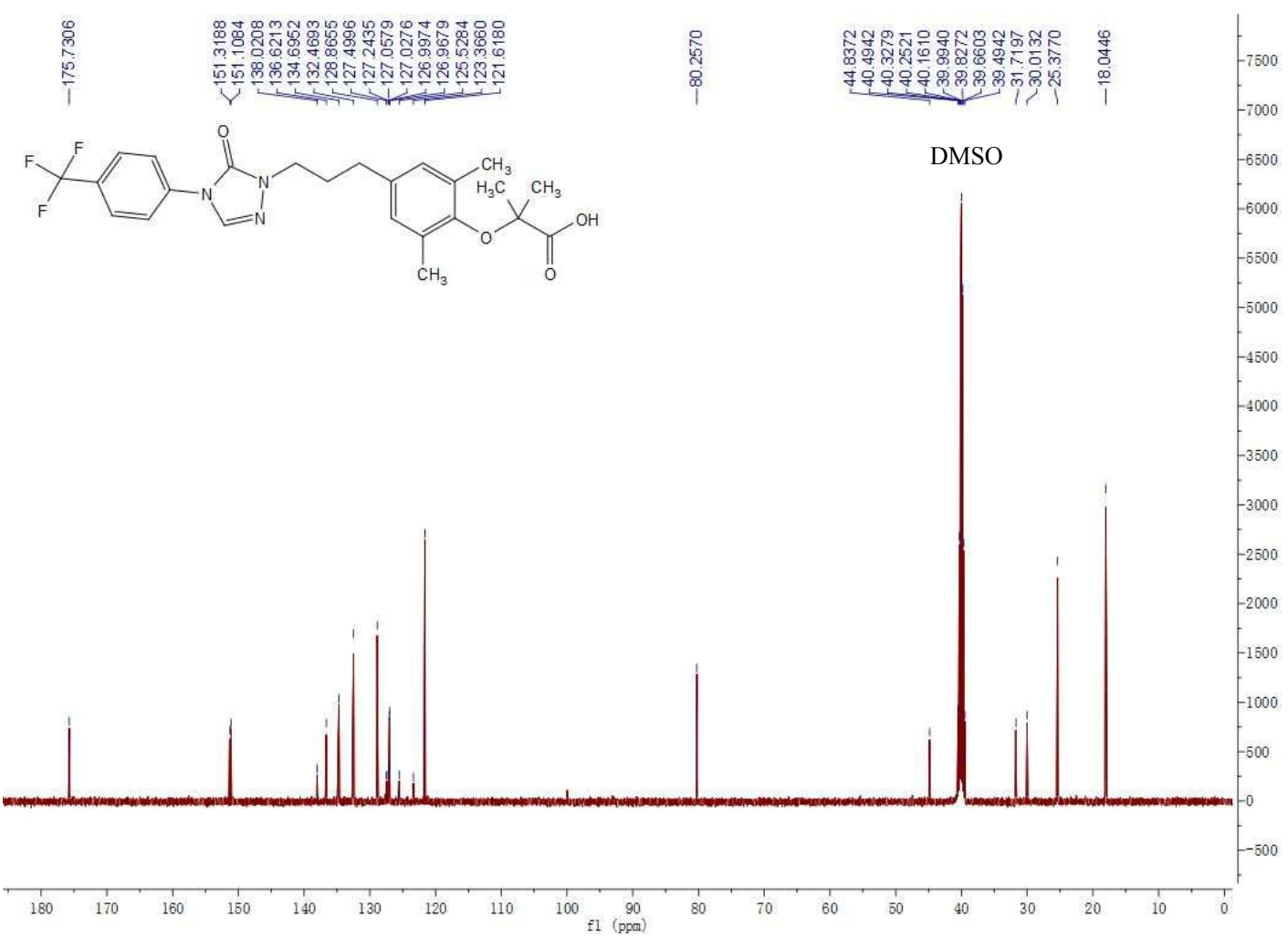


${ }^{1} \mathrm{H}-\mathrm{NMR}$ spectrum (DMSO-d6, $300 \mathrm{MHz}$ ) of $\mathrm{H} 4$

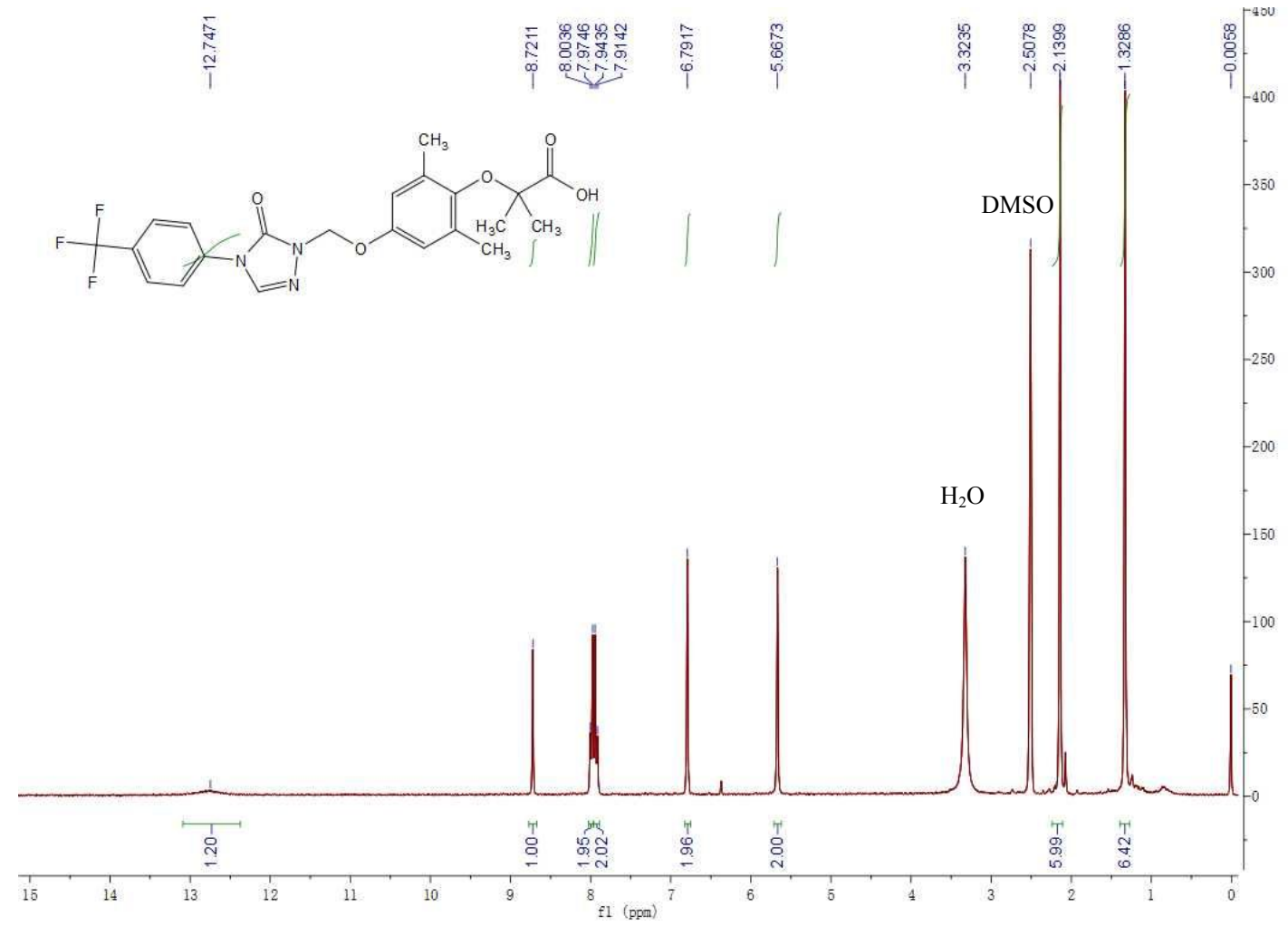

${ }^{13} \mathrm{C}-\mathrm{NMR}$ spectrum (DMSO-d6, $126 \mathrm{MHz}$ ) of $\mathrm{H} 4$

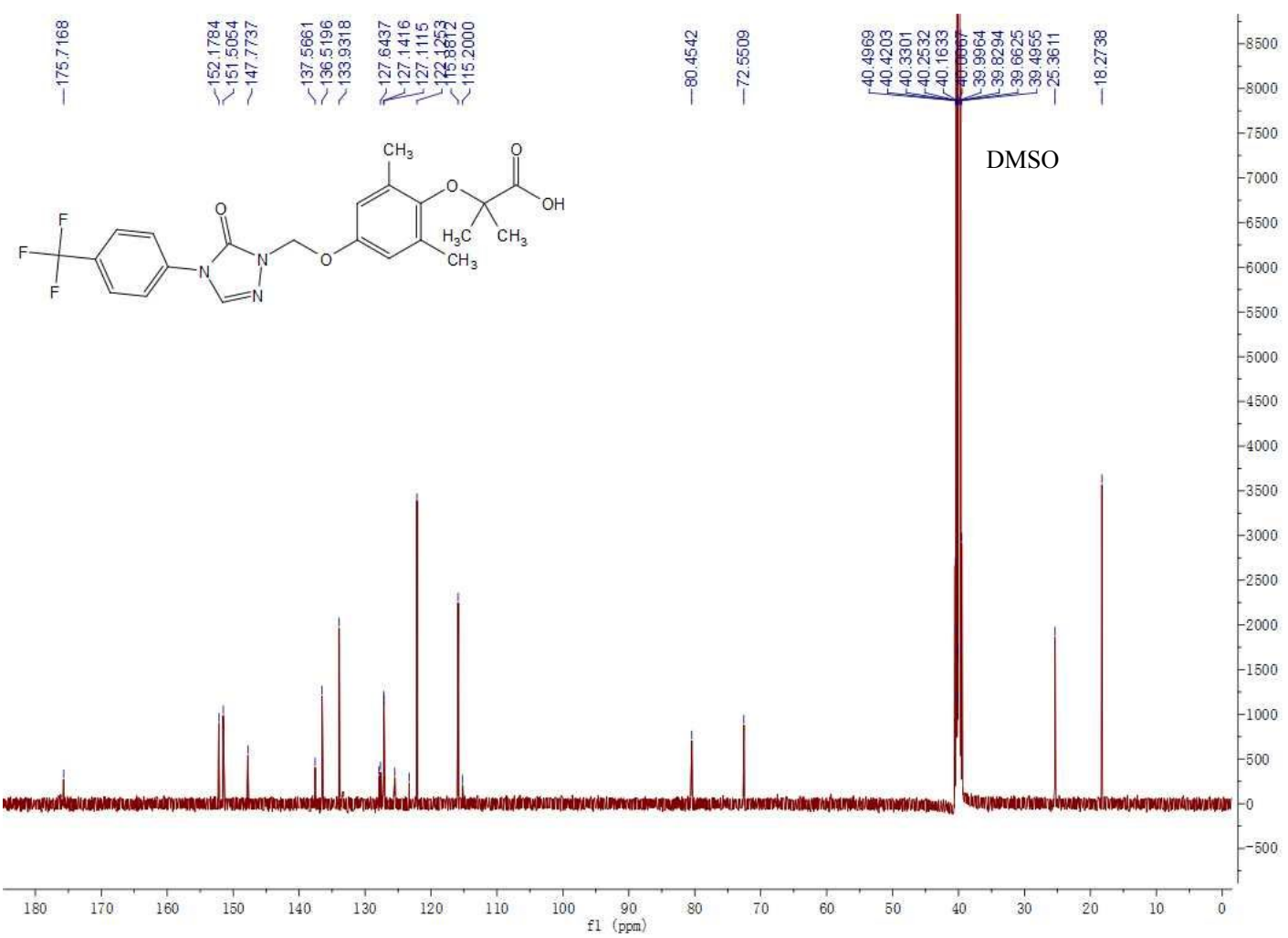


${ }^{1} \mathrm{H}-\mathrm{NMR}$ spectrum (DMSO-d6, $300 \mathrm{MHz}$ ) of $\mathrm{H} 5$

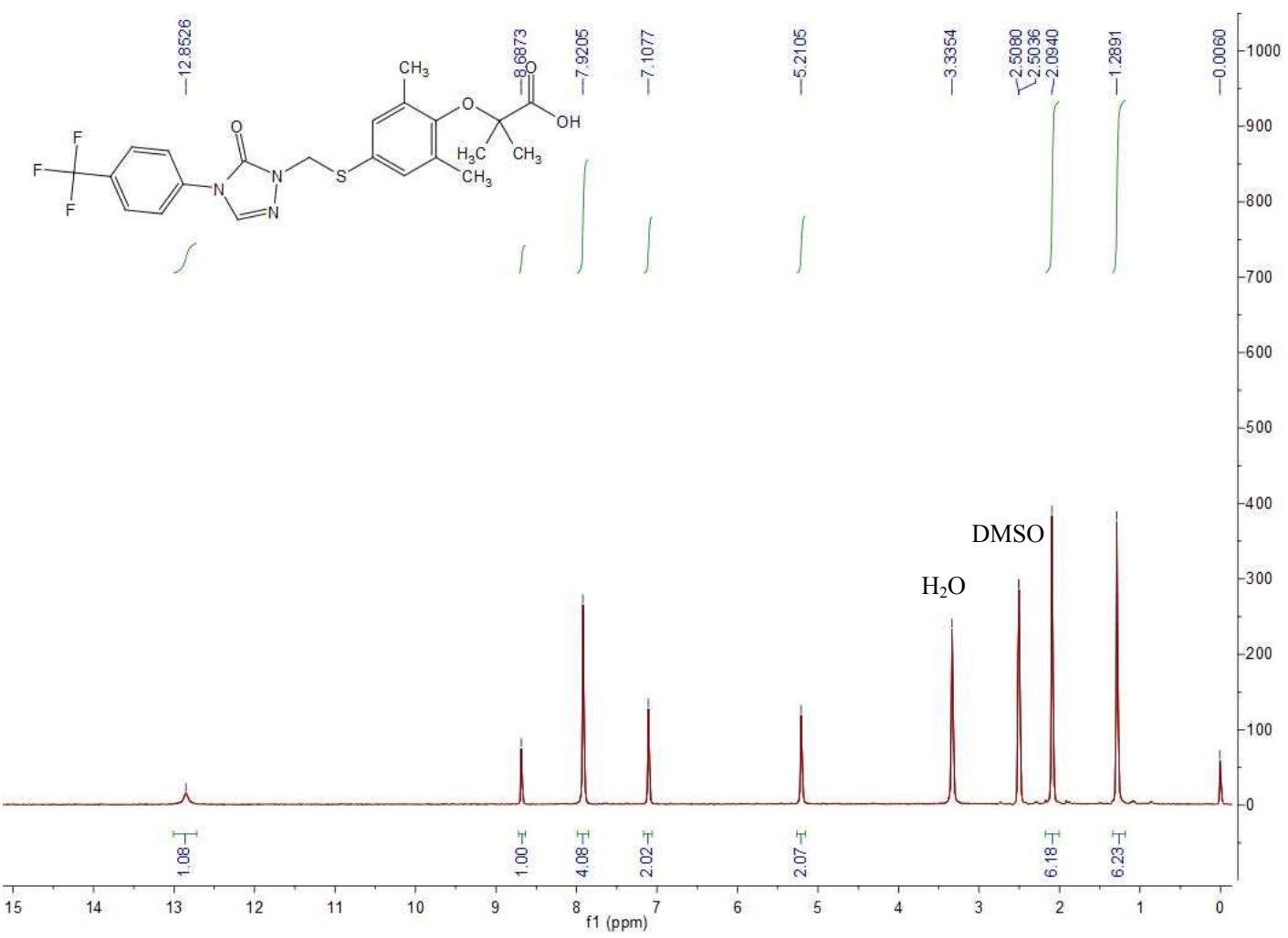

${ }^{13} \mathrm{C}-\mathrm{NMR}$ spectrum (DMSO-d6, $126 \mathrm{MHz}$ ) of $\mathrm{H} 5$

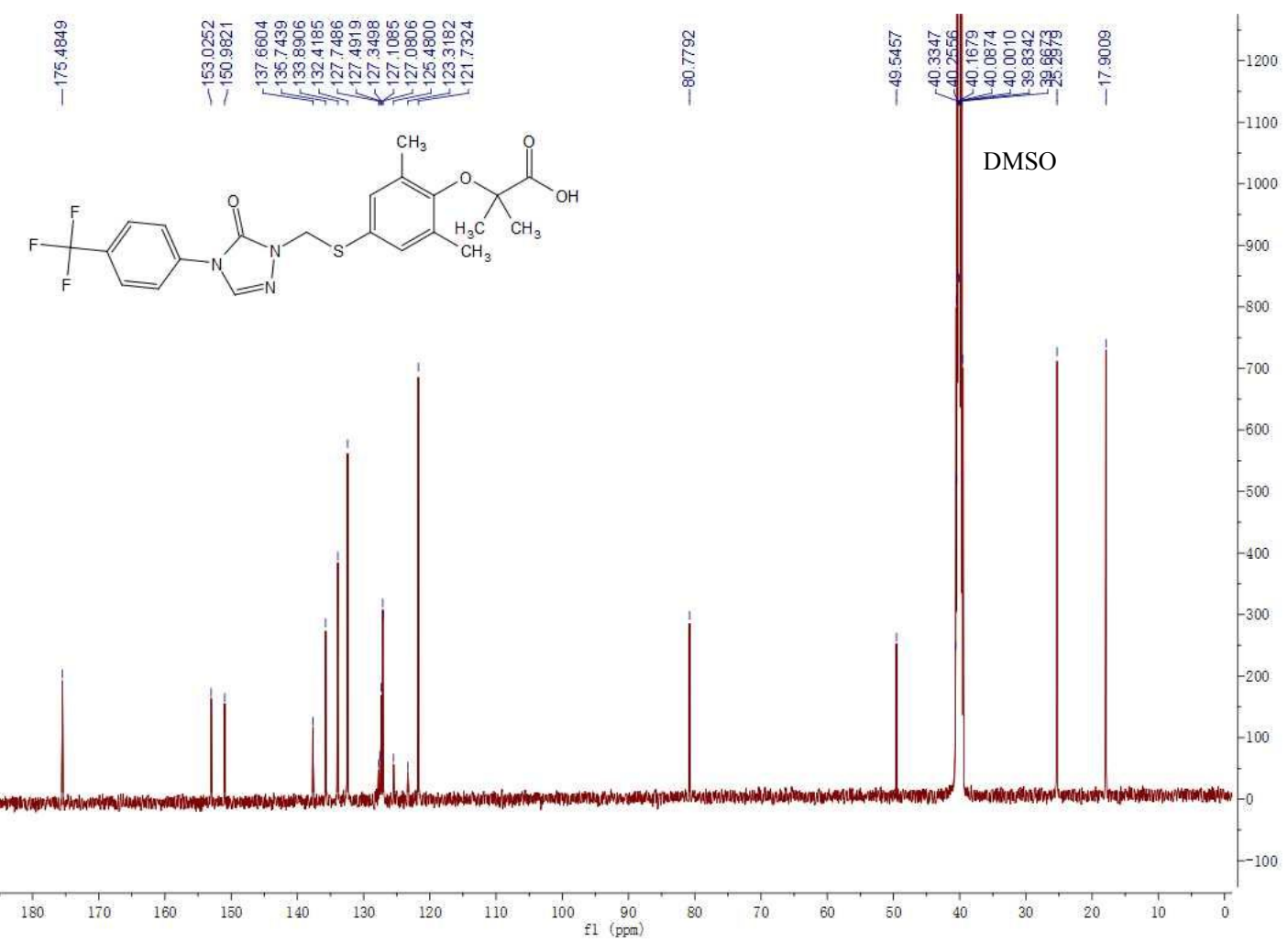


${ }^{1} \mathrm{H}-\mathrm{NMR}$ spectrum (DMSO-d6, $300 \mathrm{MHz}$ ) of $\mathrm{H} 6$

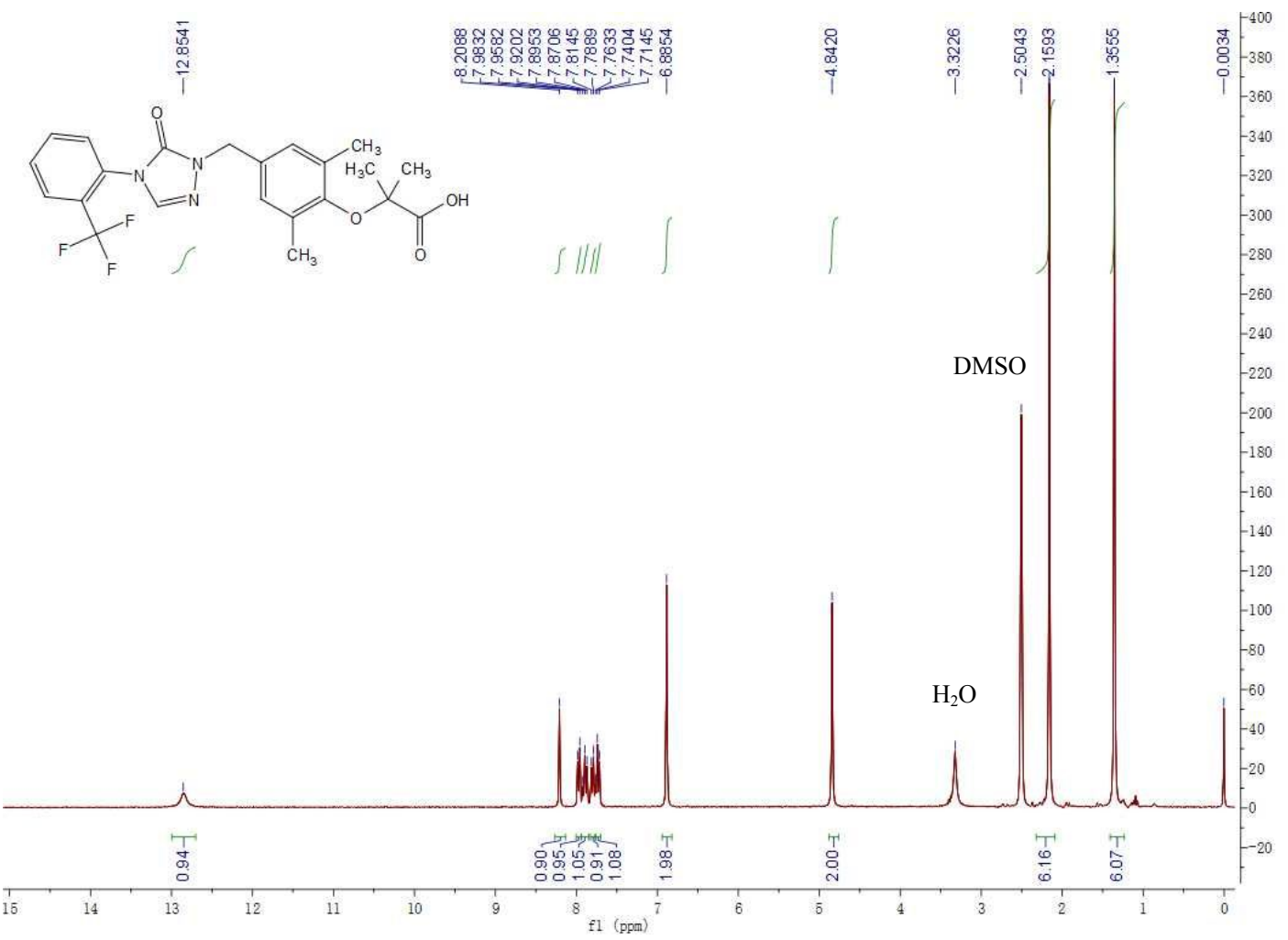

${ }^{13} \mathrm{C}-\mathrm{NMR}$ spectrum (DMSO-d6, $126 \mathrm{MHz}$ ) of $\mathrm{H} 6$
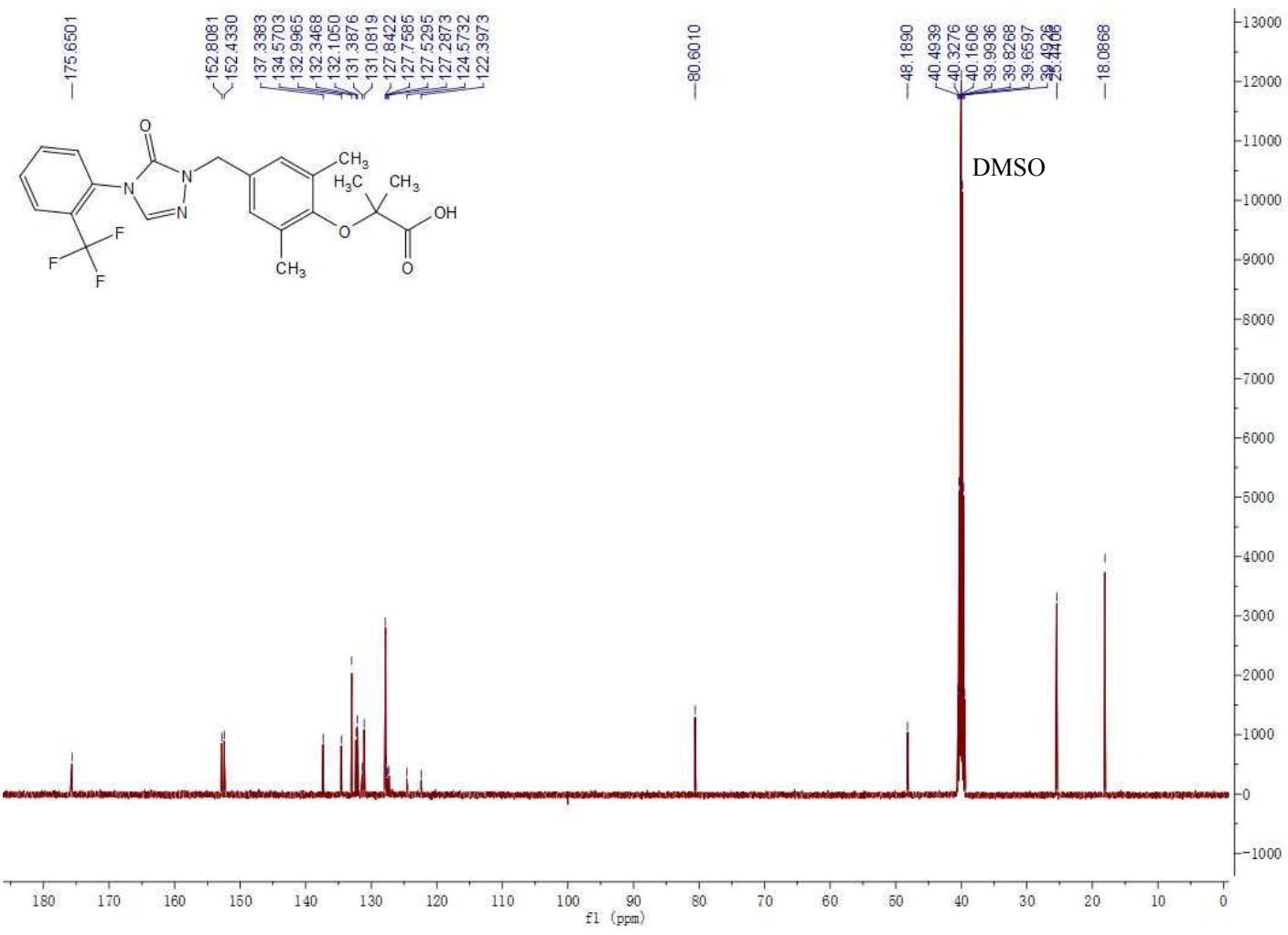
${ }^{1} \mathrm{H}-\mathrm{NMR}$ spectrum (DMSO-d6, $300 \mathrm{MHz}$ ) of $\mathrm{H} 7$

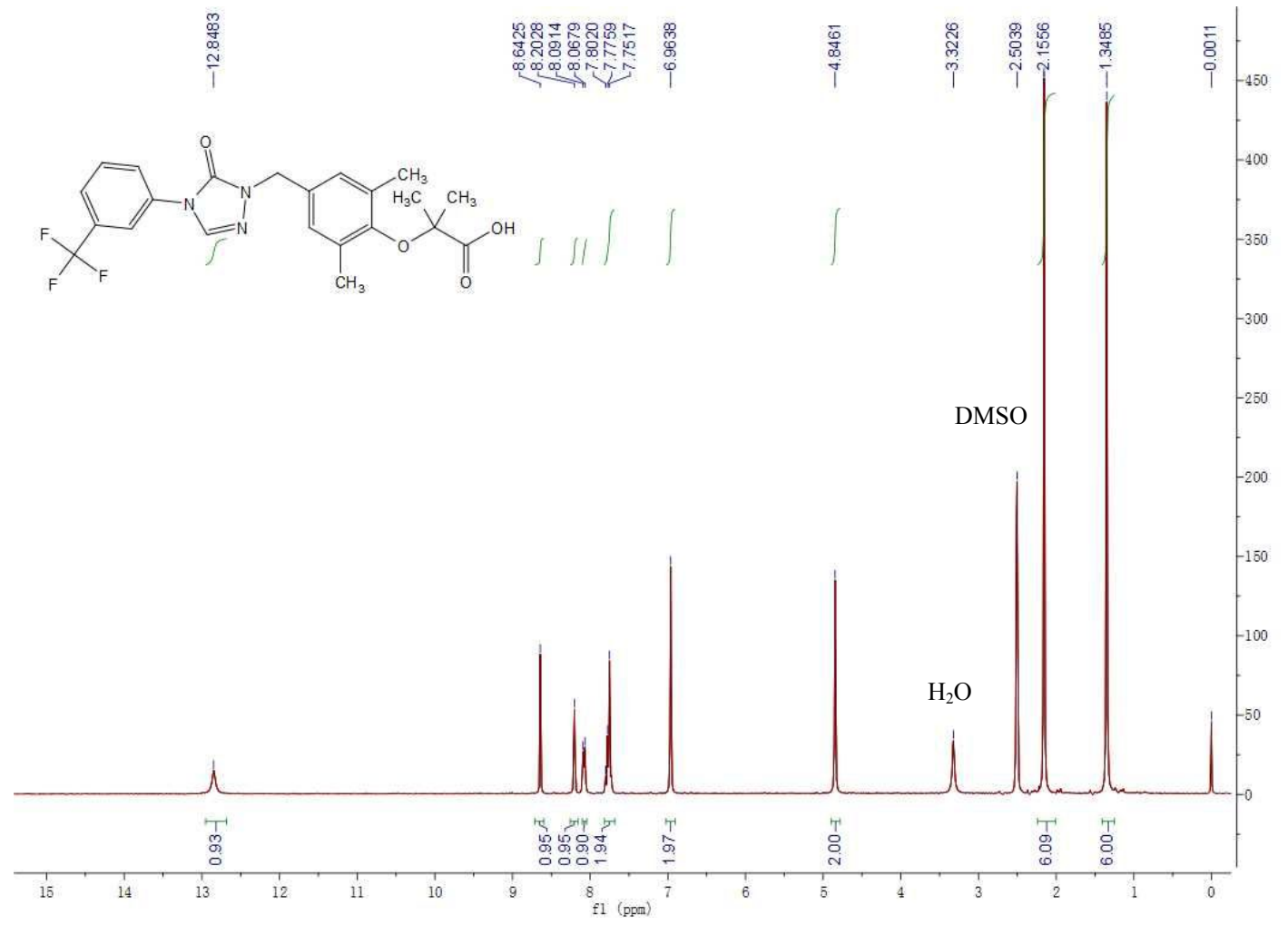

${ }^{13} \mathrm{C}-\mathrm{NMR}$ spectrum (DMSO-d6, $126 \mathrm{MHz}$ ) of $\mathrm{H} 7$
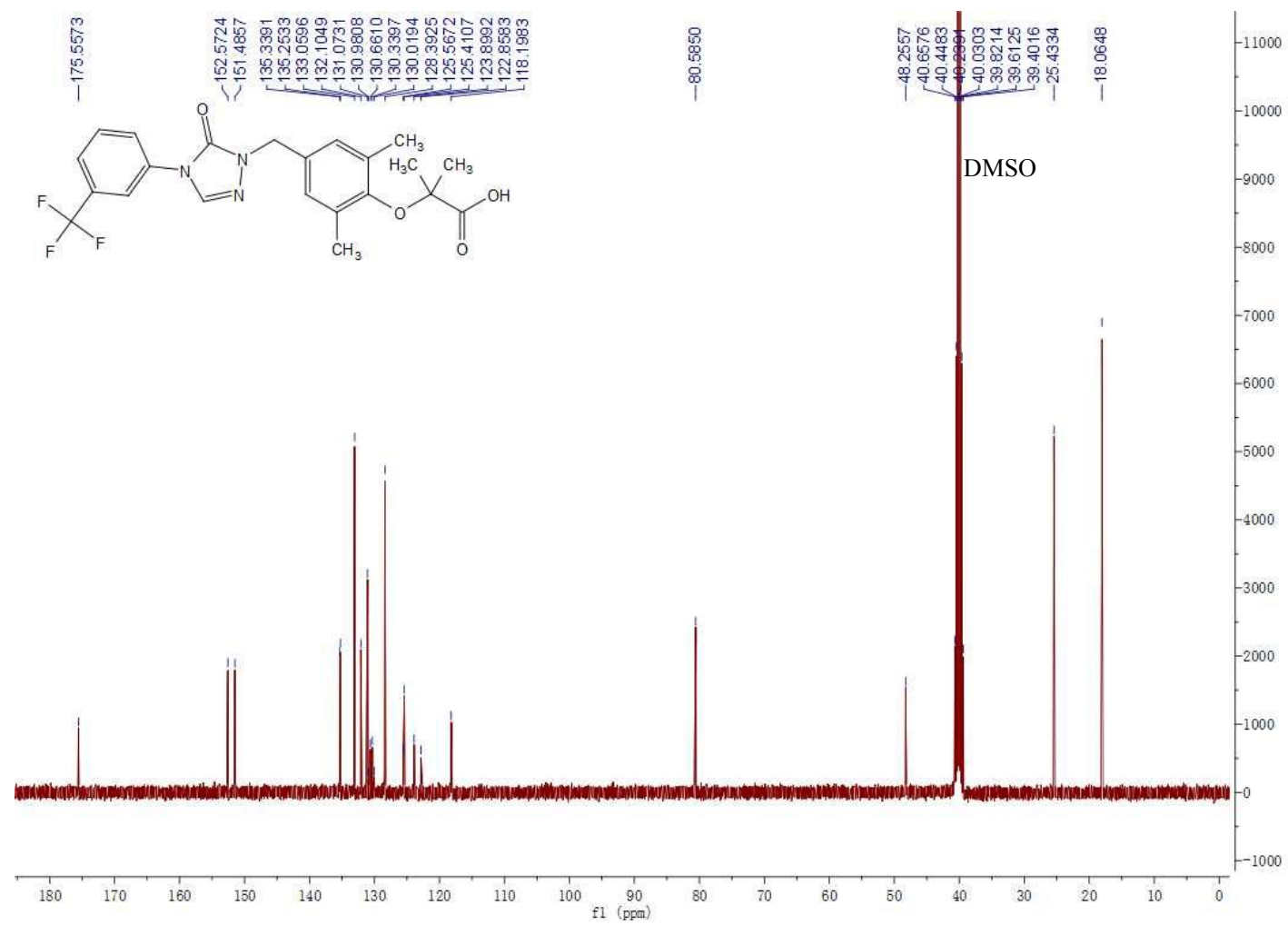
${ }^{1} \mathrm{H}-\mathrm{NMR}$ spectrum (DMSO-d6, $300 \mathrm{MHz}$ ) of $\mathrm{H} 8$

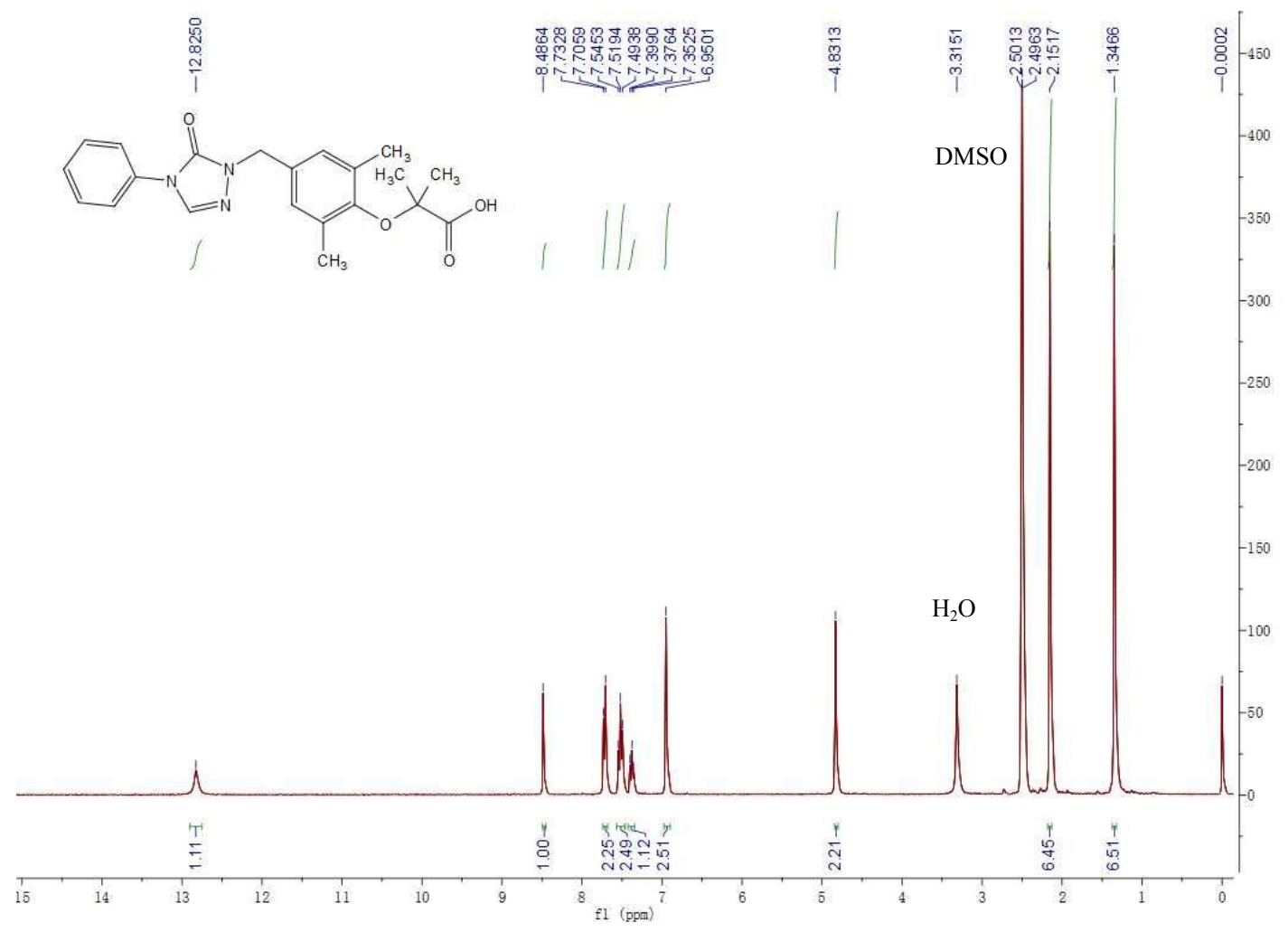

${ }^{13} \mathrm{C}-\mathrm{NMR}$ spectrum (DMSO- $d 6,126 \mathrm{MHz}$ ) of $\mathrm{H} 8$

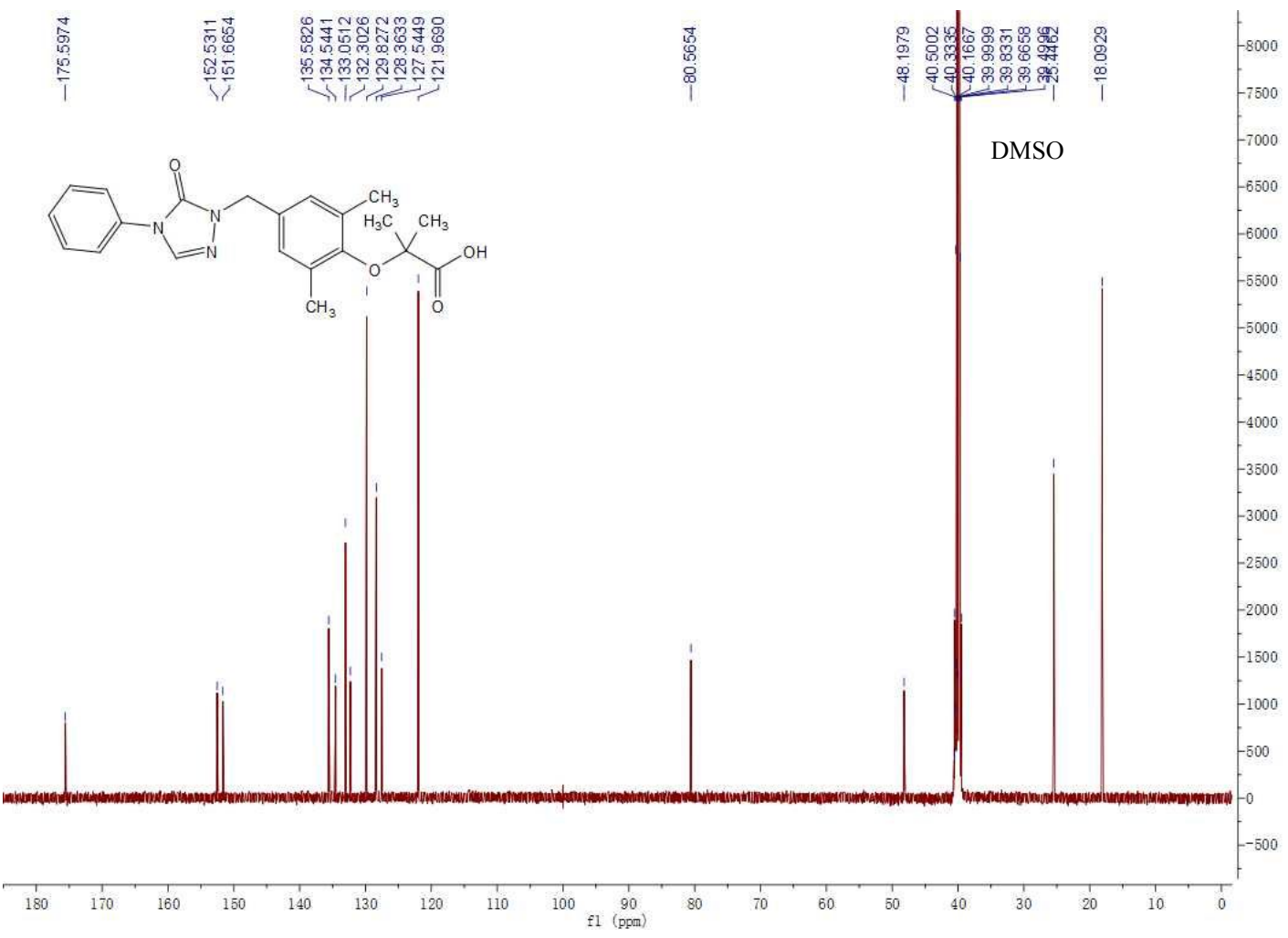


${ }^{1} \mathrm{H}-\mathrm{NMR}$ spectrum (DMSO-d6, $300 \mathrm{MHz}$ ) of $\mathrm{H} 9$

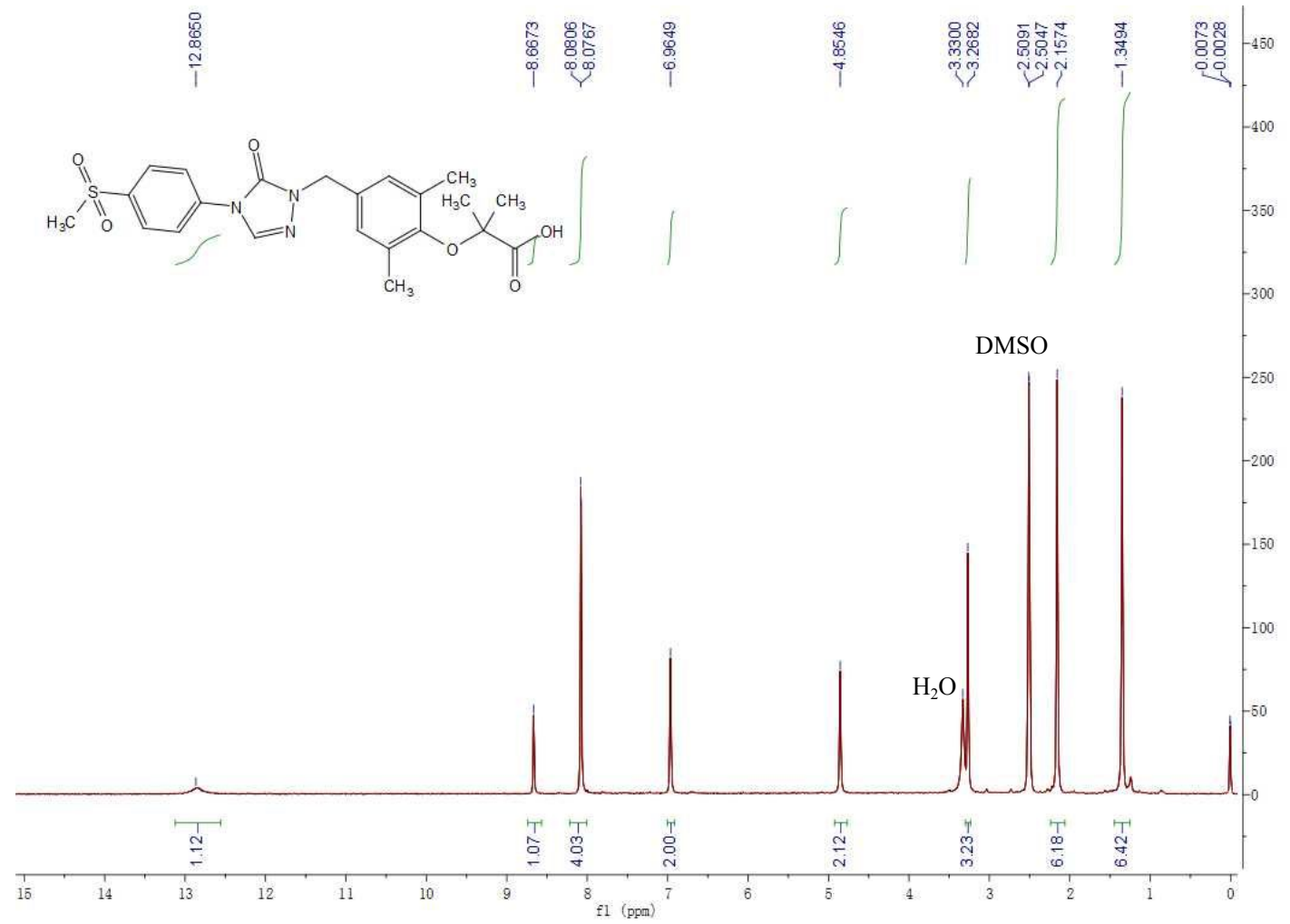

${ }^{13} \mathrm{C}-\mathrm{NMR}$ spectrum (DMSO-d6, $126 \mathrm{MHz}$ ) of $\mathrm{H} 9$

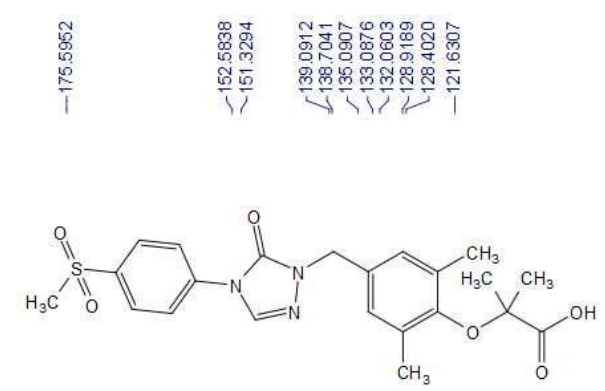

$m$
0
0
0
1
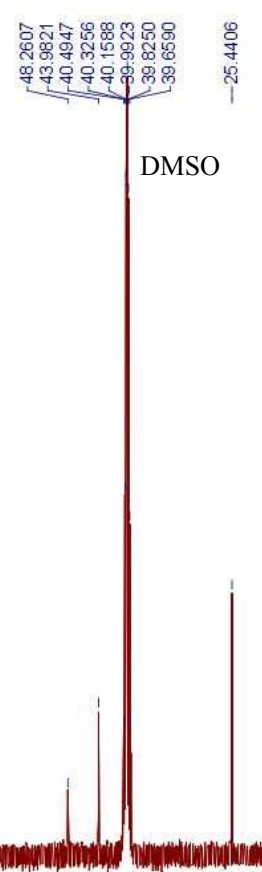

1300
1200
1100
1000
900
300
-00
500
500
100
300
200
100

$\begin{array}{llllllllll}180 & 170 & 160 & 150 & 140 & 130 & 120 & 110 & 100 & 90 \\ \mathrm{f} 1 & (\mathrm{pgm})\end{array}$ 
${ }^{1} \mathrm{H}-\mathrm{NMR}$ spectrum (DMSO-d6, $300 \mathrm{MHz}$ ) of H10

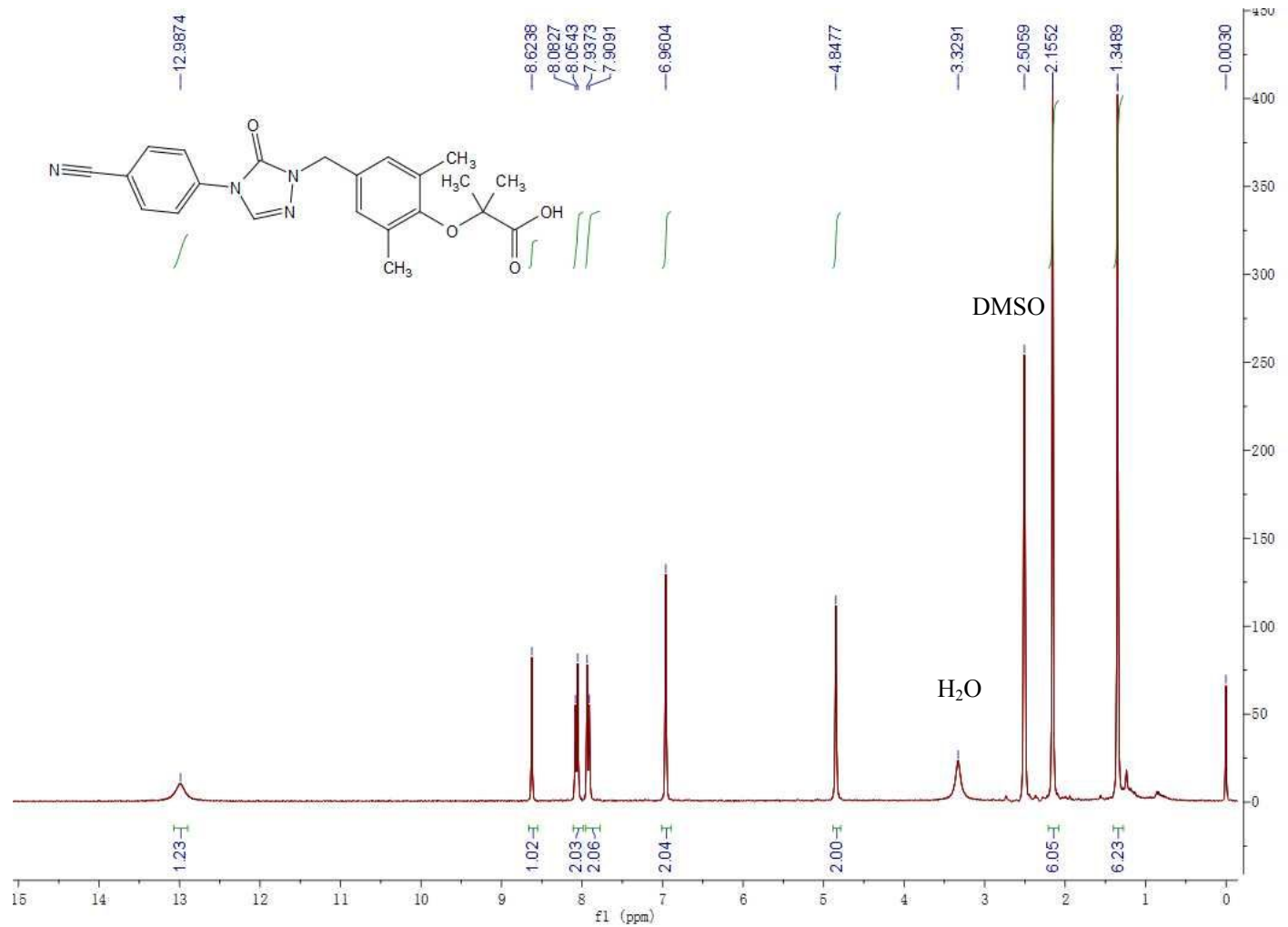

${ }^{13} \mathrm{C}-\mathrm{NMR}$ spectrum (DMSO-d6, $126 \mathrm{MHz}$ ) of $\mathrm{H} 10$
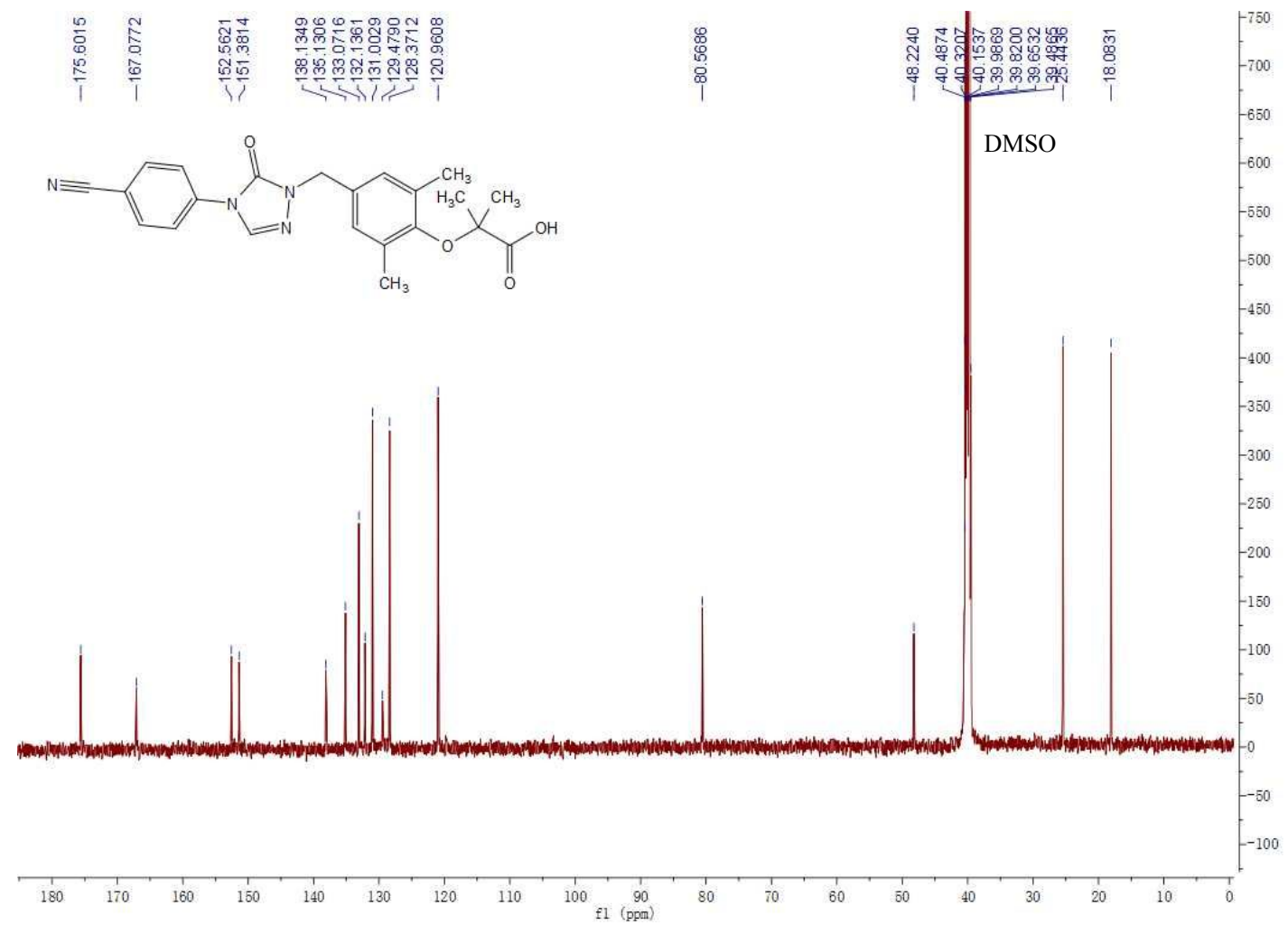
${ }^{1} \mathrm{H}-\mathrm{NMR}$ spectrum (DMSO-d6, $300 \mathrm{MHz}$ ) of $\mathrm{H} 11$

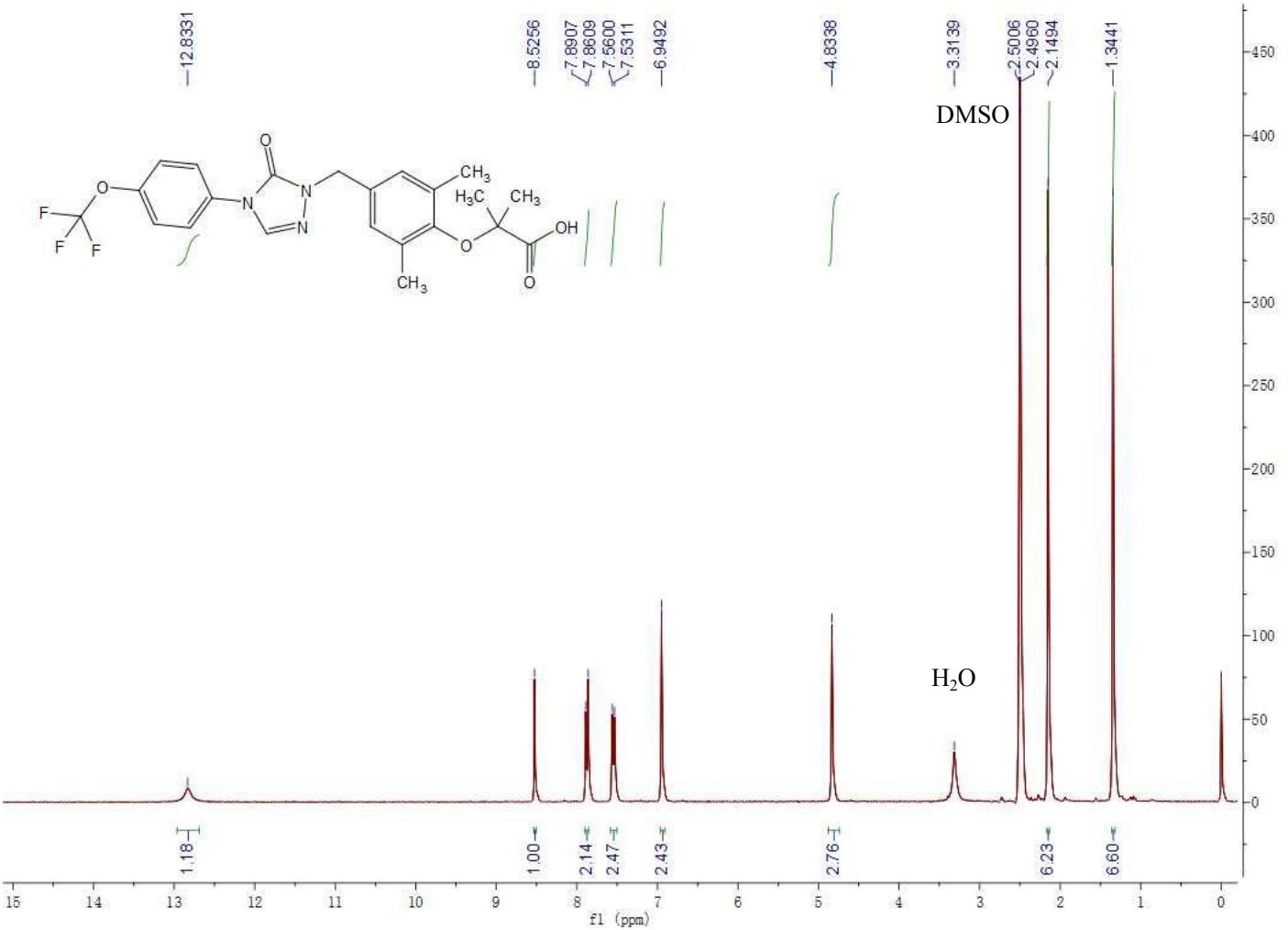

${ }^{13} \mathrm{C}-\mathrm{NMR}$ spectrum (DMSO-d6, $126 \mathrm{MHz}$ ) of $\mathrm{H} 11$

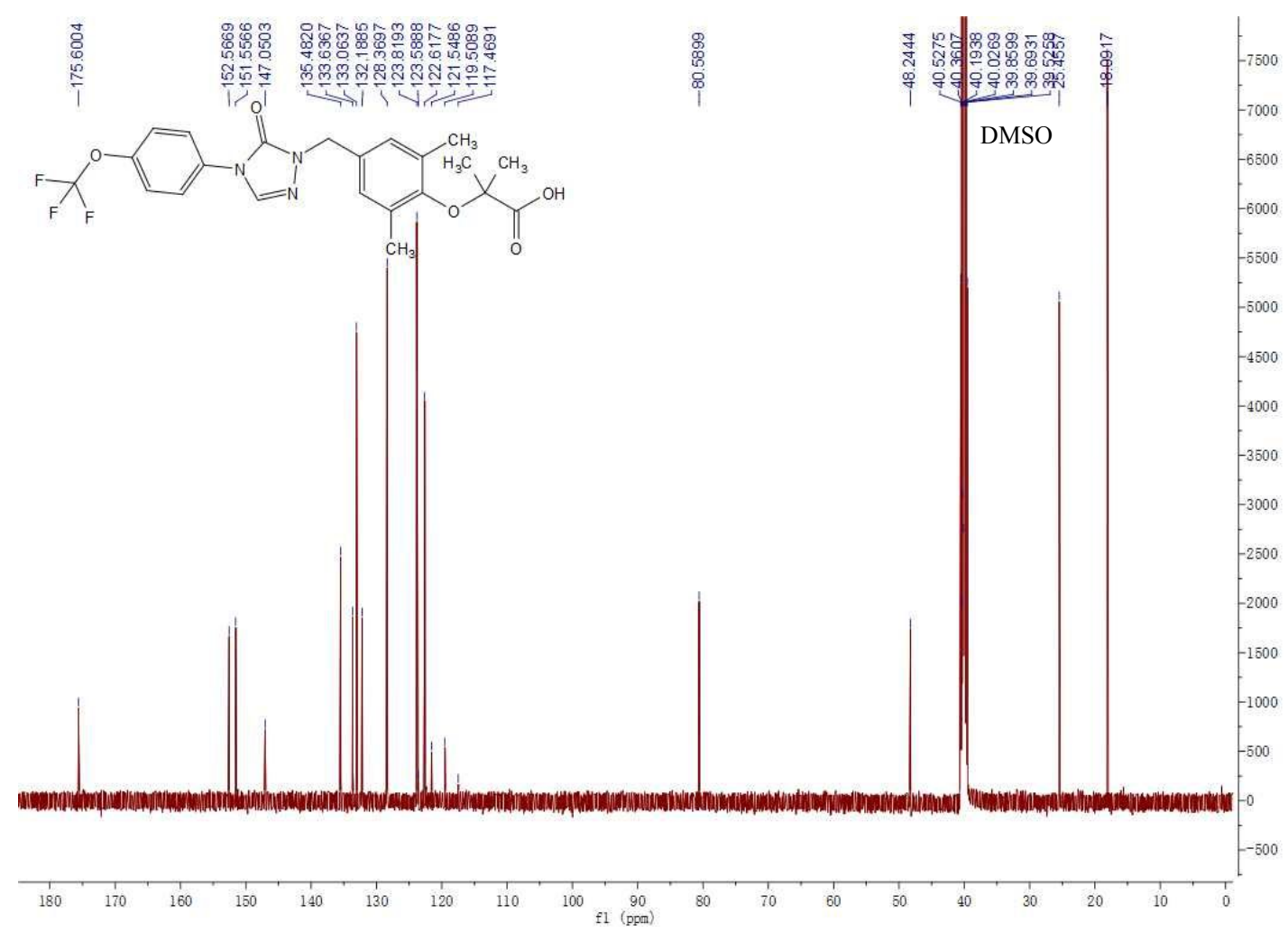


${ }^{1} \mathrm{H}-\mathrm{NMR}$ spectrum (DMSO-d6, $300 \mathrm{MHz}$ ) of H12

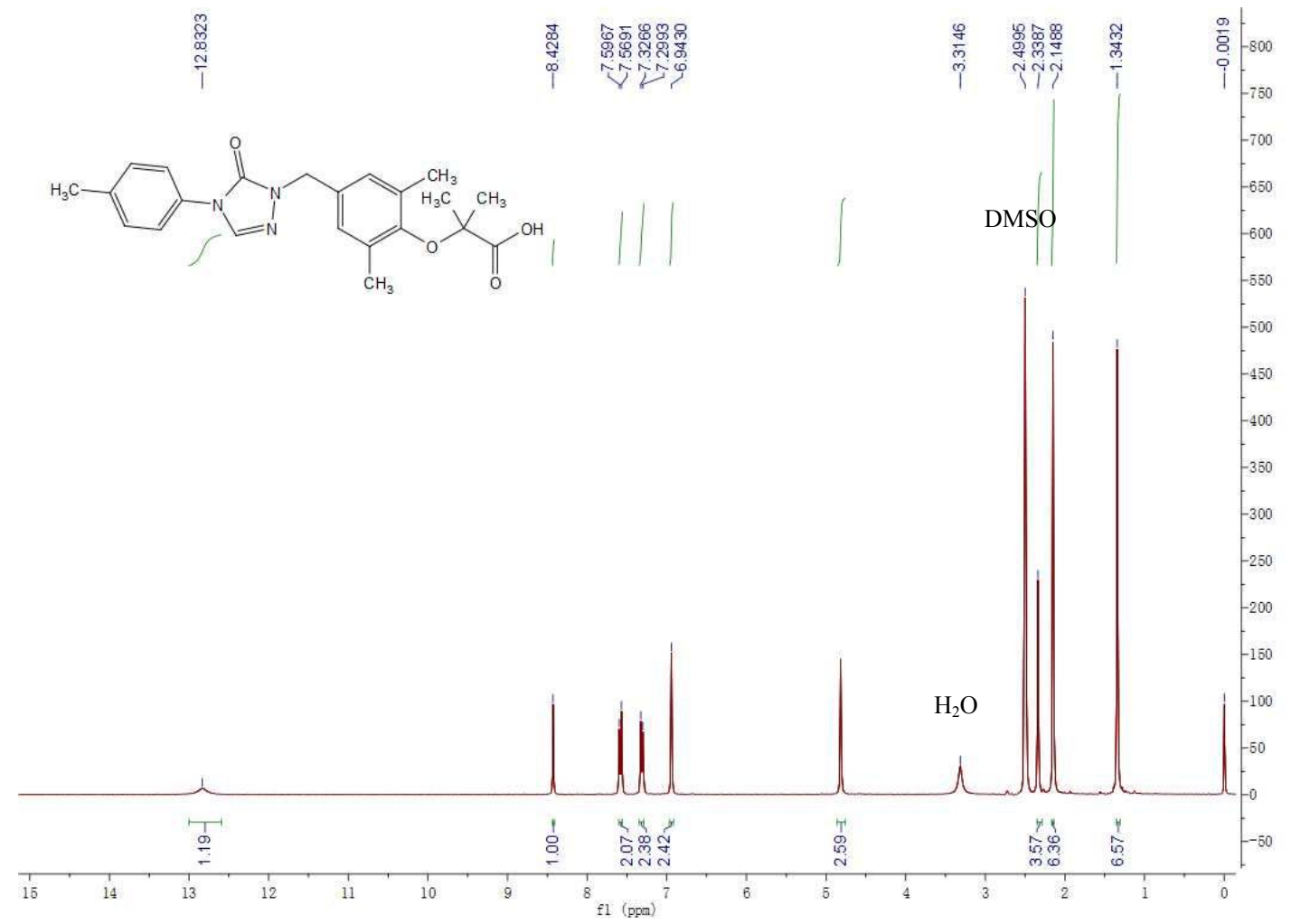

${ }^{13} \mathrm{C}-\mathrm{NMR}$ spectrum (DMSO-d6, $126 \mathrm{MHz}$ ) of $\mathrm{H} 12$

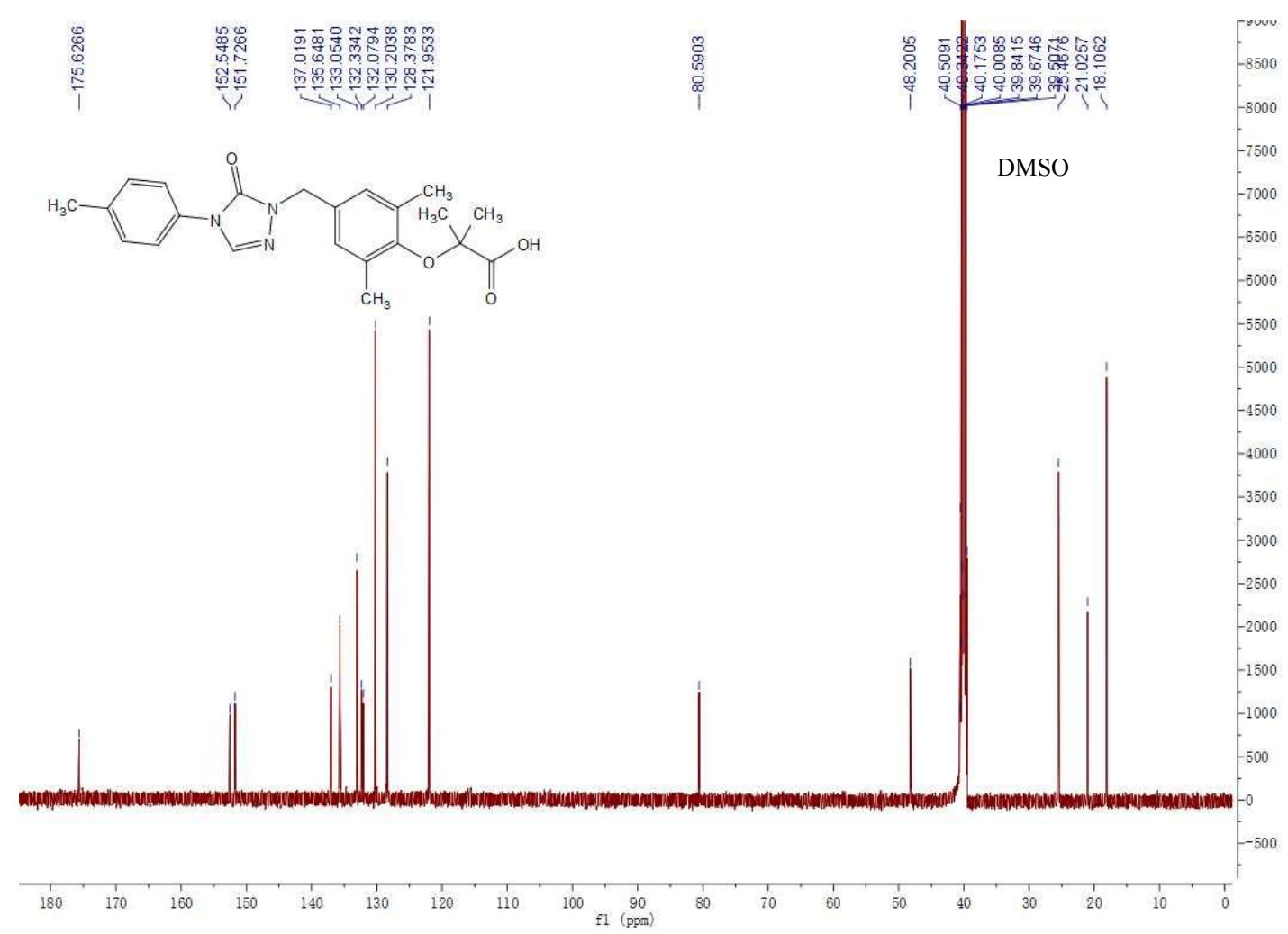


${ }^{1} \mathrm{H}-\mathrm{NMR}$ spectrum (DMSO-d6, $300 \mathrm{MHz}$ ) of $\mathrm{H} 13$

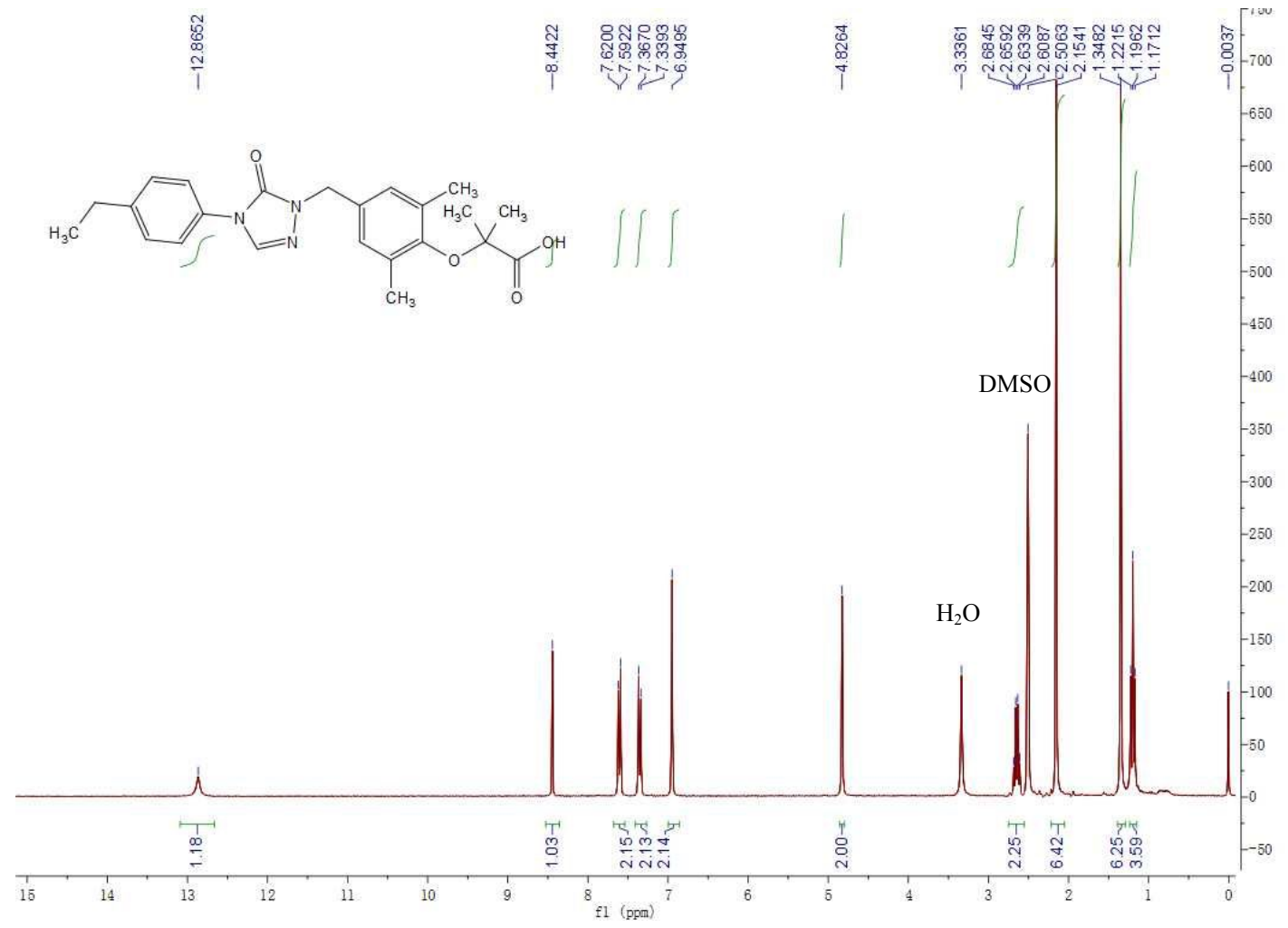

${ }^{13} \mathrm{C}-\mathrm{NMR}$ spectrum (DMSO-d6, $126 \mathrm{MHz}$ ) of $\mathrm{H} 13$

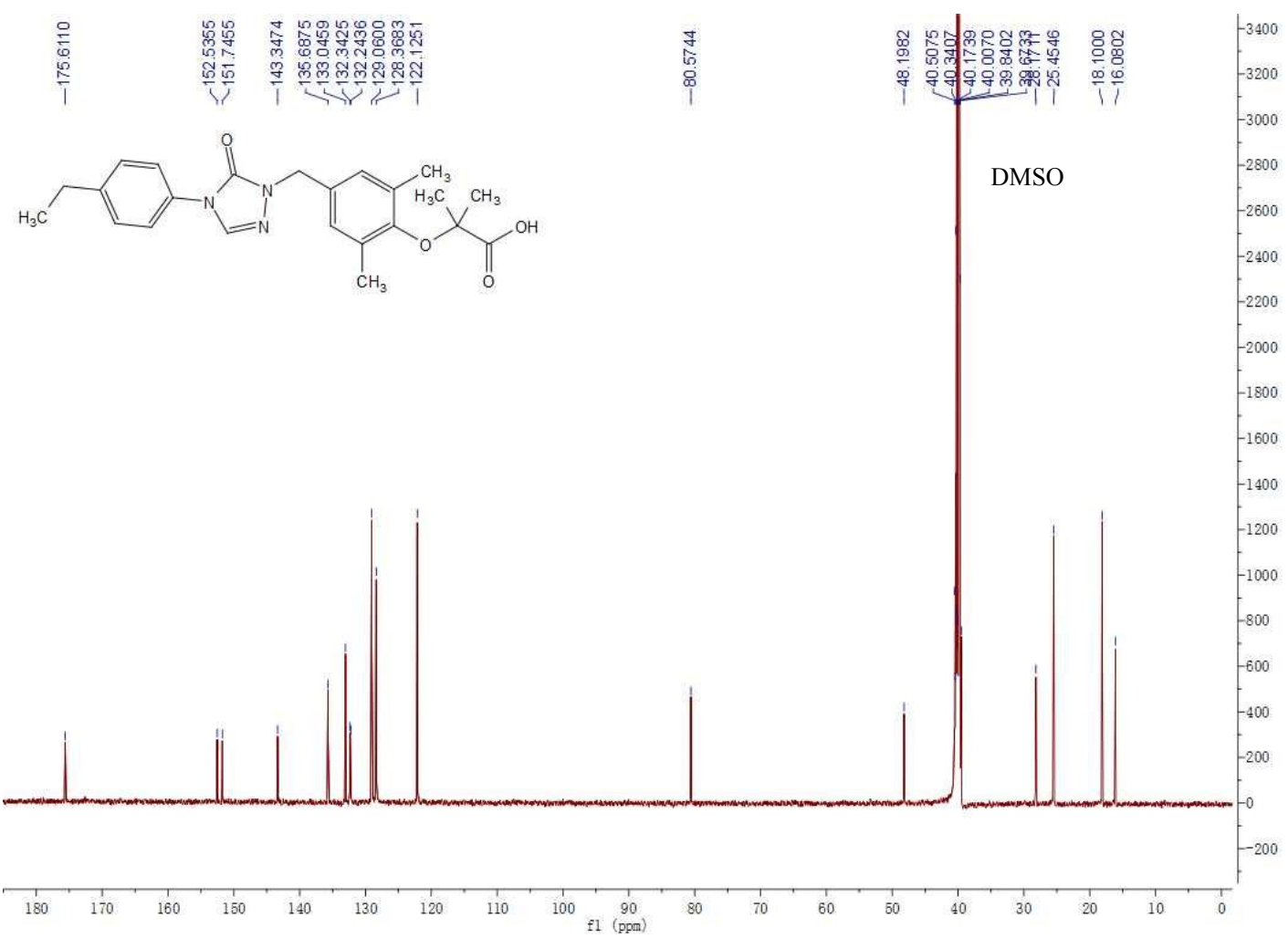


${ }^{1} \mathrm{H}-\mathrm{NMR}$ spectrum (DMSO-d6, $300 \mathrm{MHz}$ ) of H14

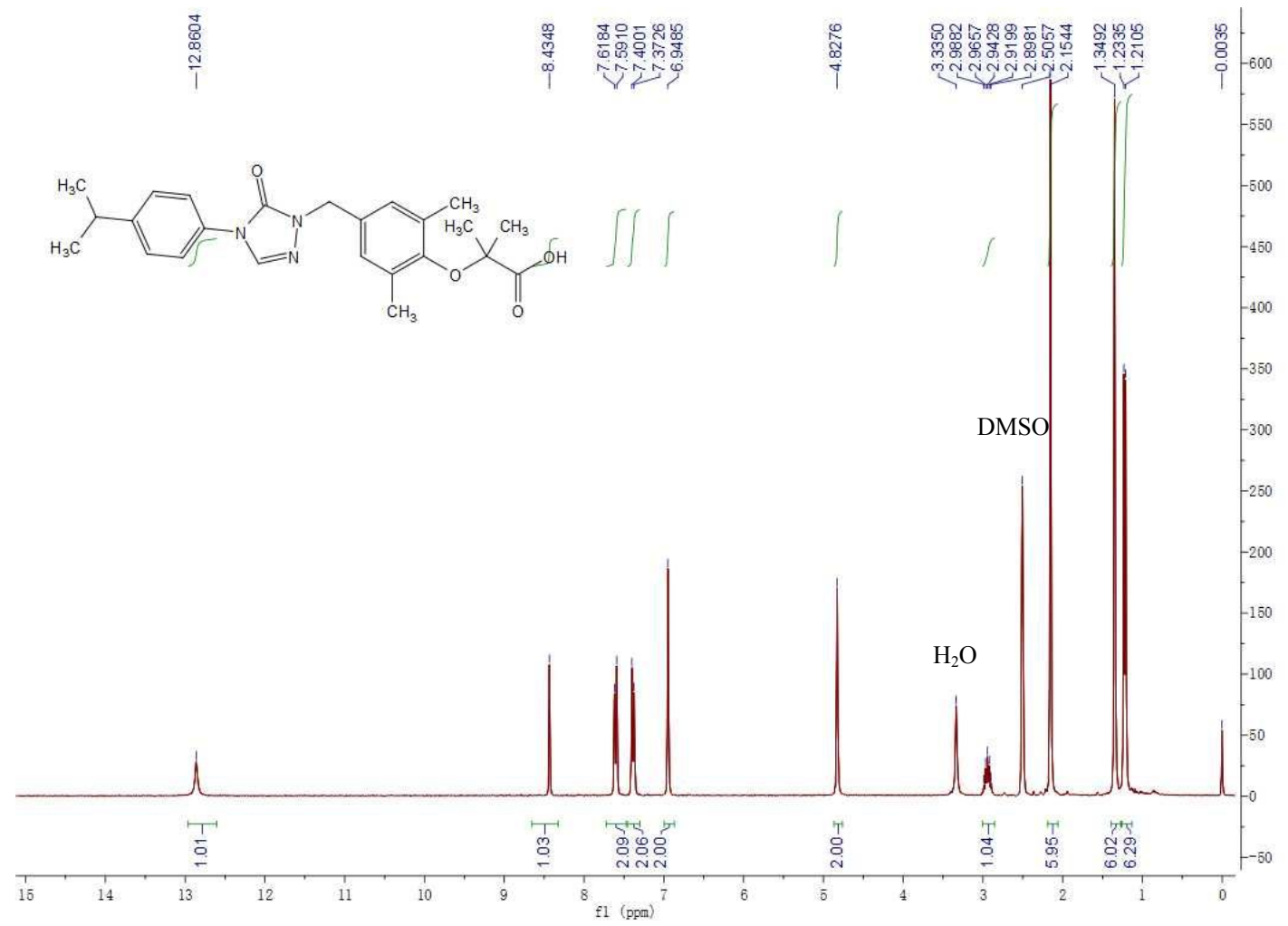

${ }^{13} \mathrm{C}-\mathrm{NMR}$ spectrum (DMSO-d6, $126 \mathrm{MHz}$ ) of H14

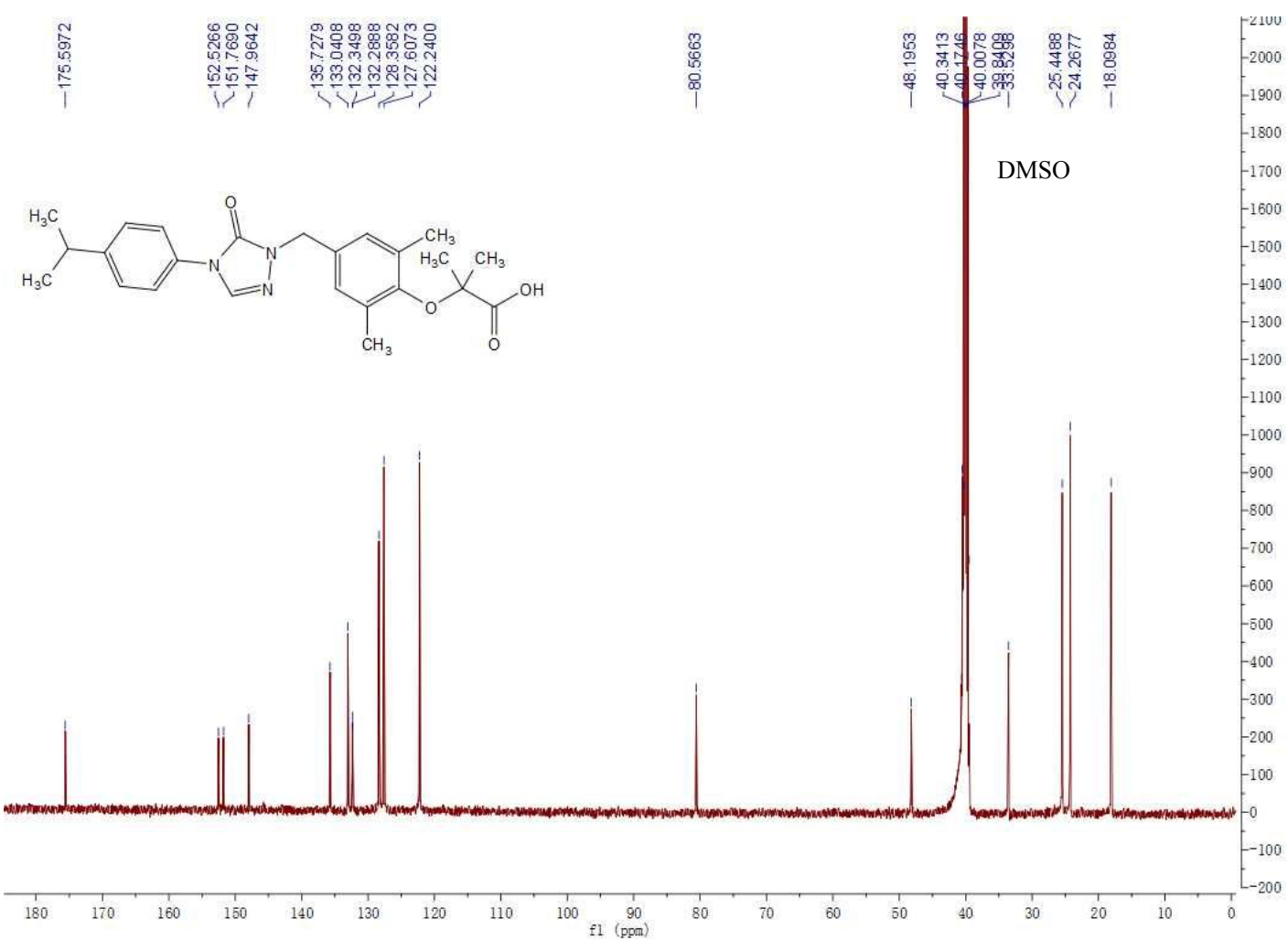


${ }^{1} \mathrm{H}-\mathrm{NMR}$ spectrum (DMSO-d6, $300 \mathrm{MHz}$ ) of H15

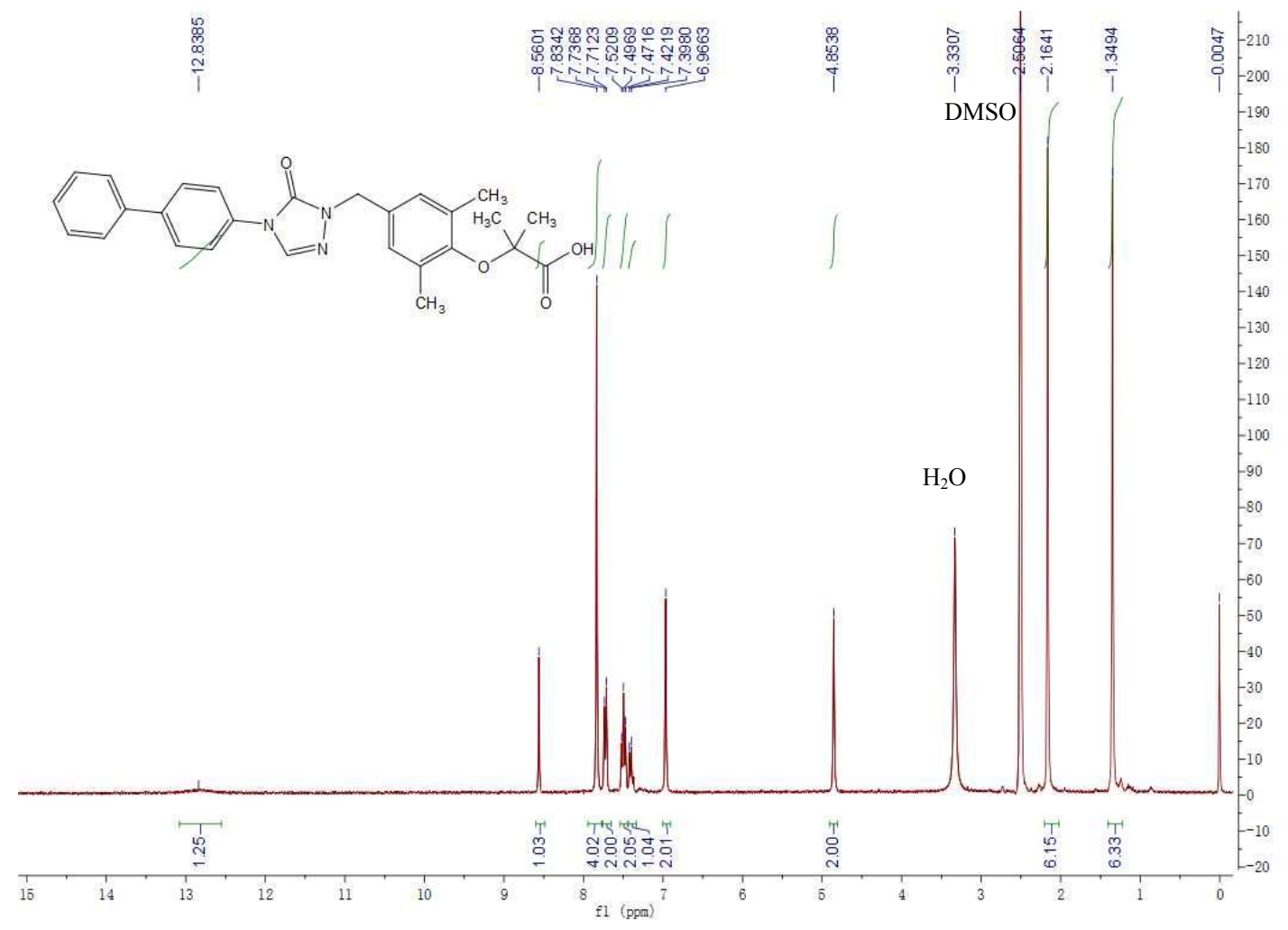

${ }^{13} \mathrm{C}-\mathrm{NMR}$ spectrum (DMSO-d6, $126 \mathrm{MHz}$ ) of $\mathrm{H} 15$

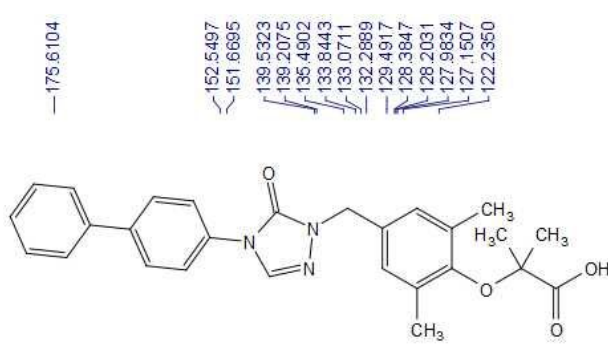

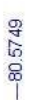
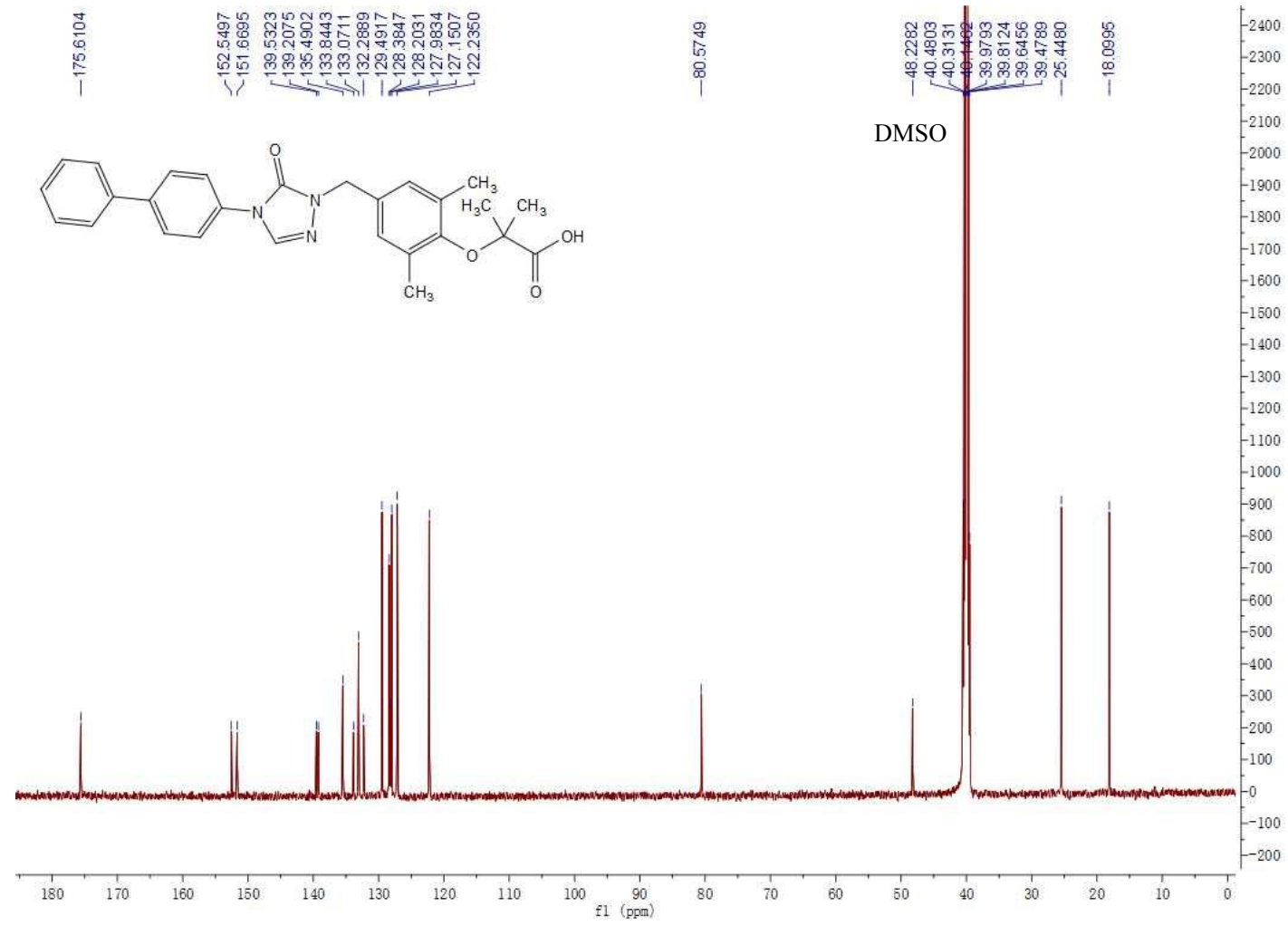
${ }^{1} \mathrm{H}-\mathrm{NMR}$ spectrum (DMSO-d6, $300 \mathrm{MHz}$ ) of H16

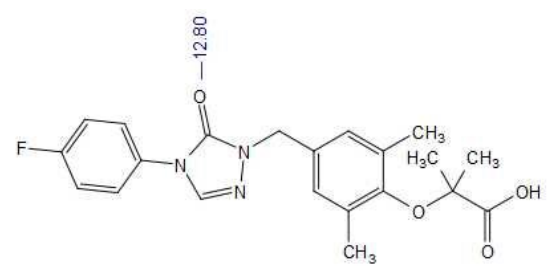

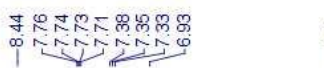

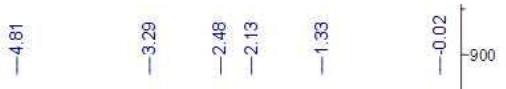

$-800$

700

600

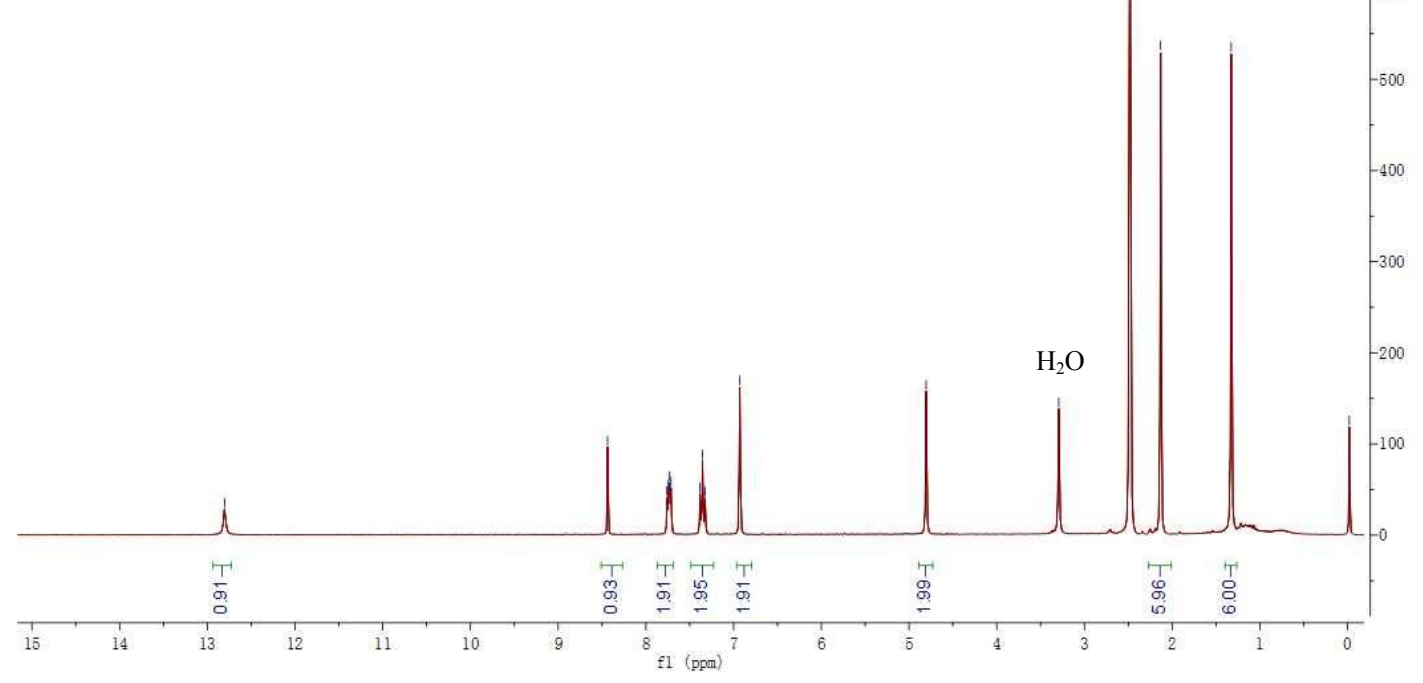

${ }^{13} \mathrm{C}-\mathrm{NMR}$ spectrum (DMSO-d6, $126 \mathrm{MHz}$ ) of H16

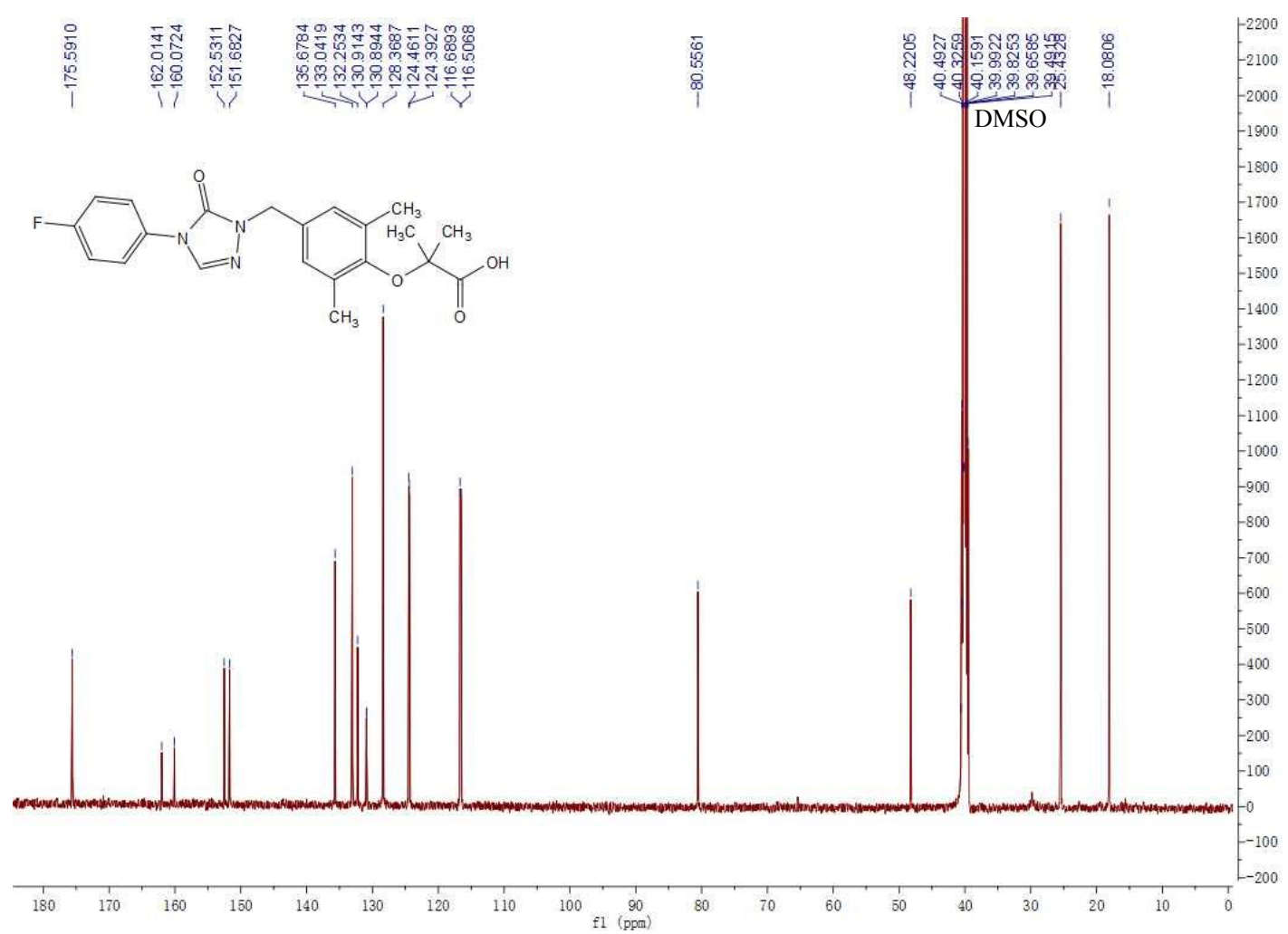


${ }^{1} \mathrm{H}-\mathrm{NMR}$ spectrum (DMSO-d6, $300 \mathrm{MHz}$ ) of $\mathrm{H} 17$

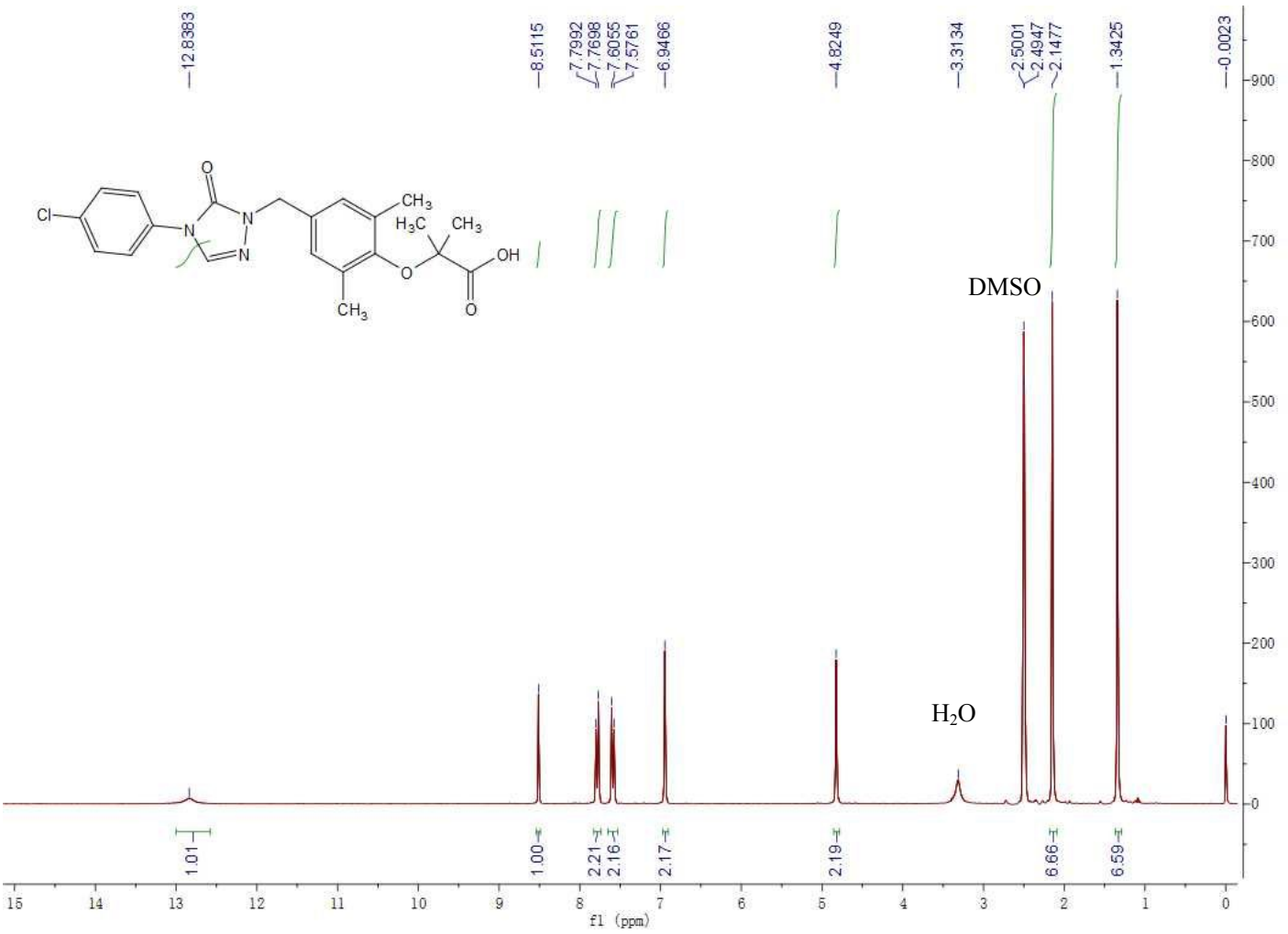

${ }^{13} \mathrm{C}-\mathrm{NMR}$ spectrum (DMSO-d6, $126 \mathrm{MHz}$ ) of $\mathrm{H} 17$

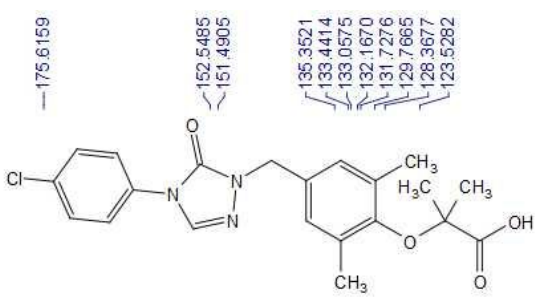

$\stackrel{\infty}{5}$

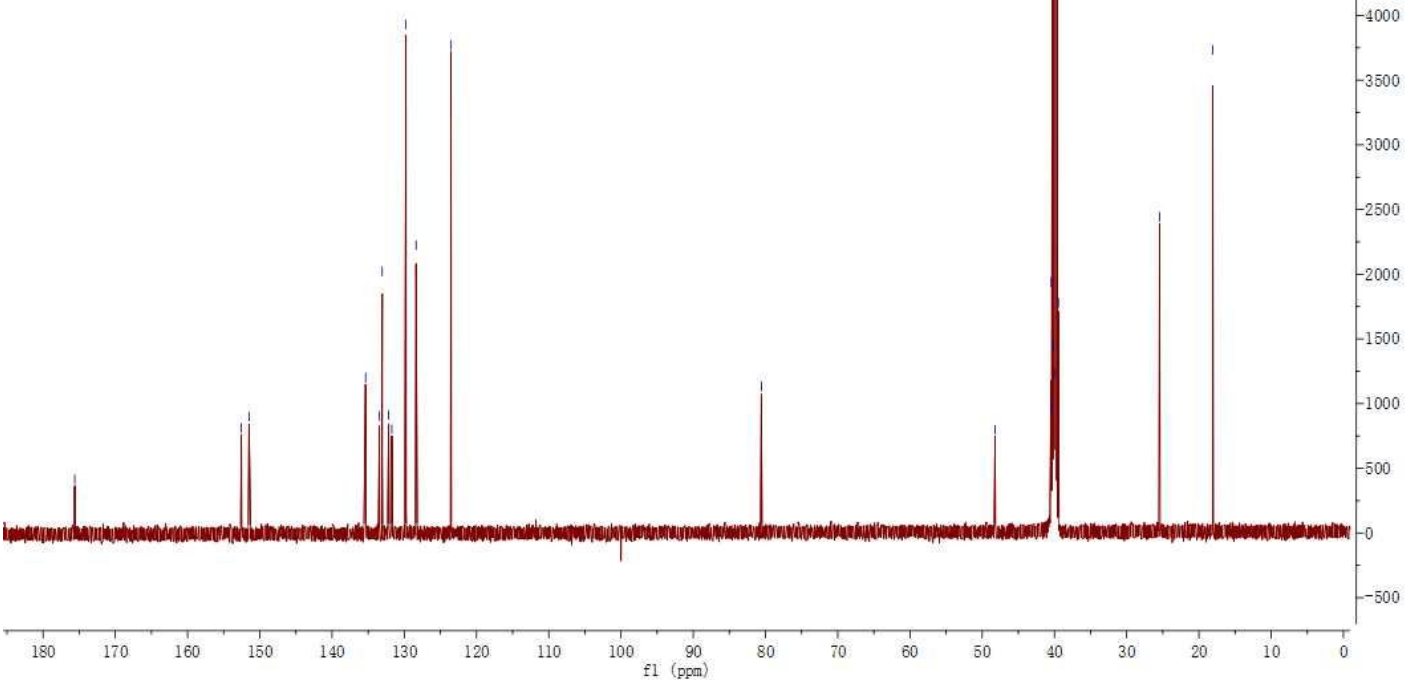


${ }^{1} \mathrm{H}-\mathrm{NMR}$ spectrum (DMSO-d6, $300 \mathrm{MHz}$ ) of $\mathrm{H} 18$

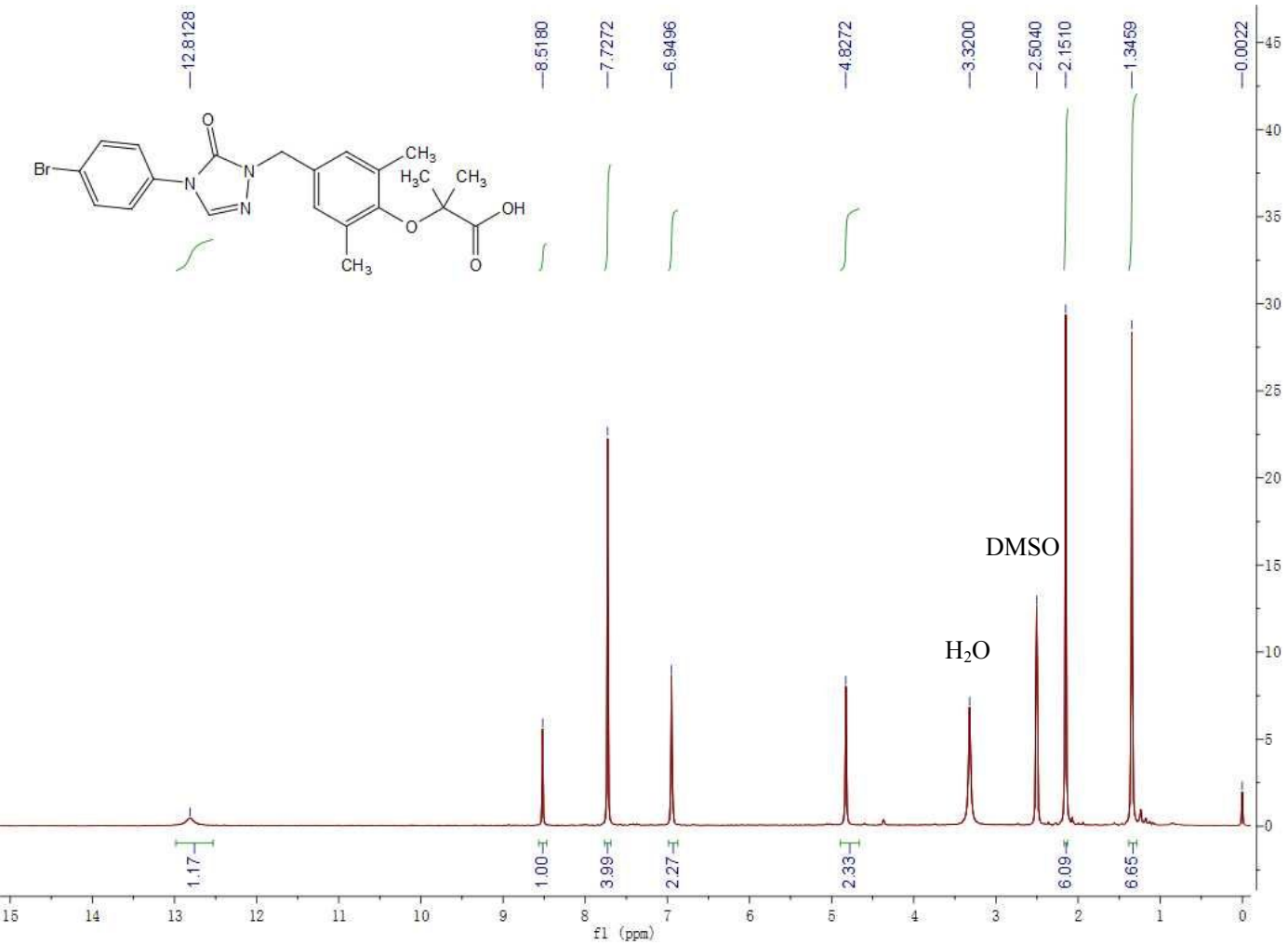

${ }^{13} \mathrm{C}-\mathrm{NMR}$ spectrum (DMSO-d6, $126 \mathrm{MHz}$ ) of $\mathrm{H} 18$

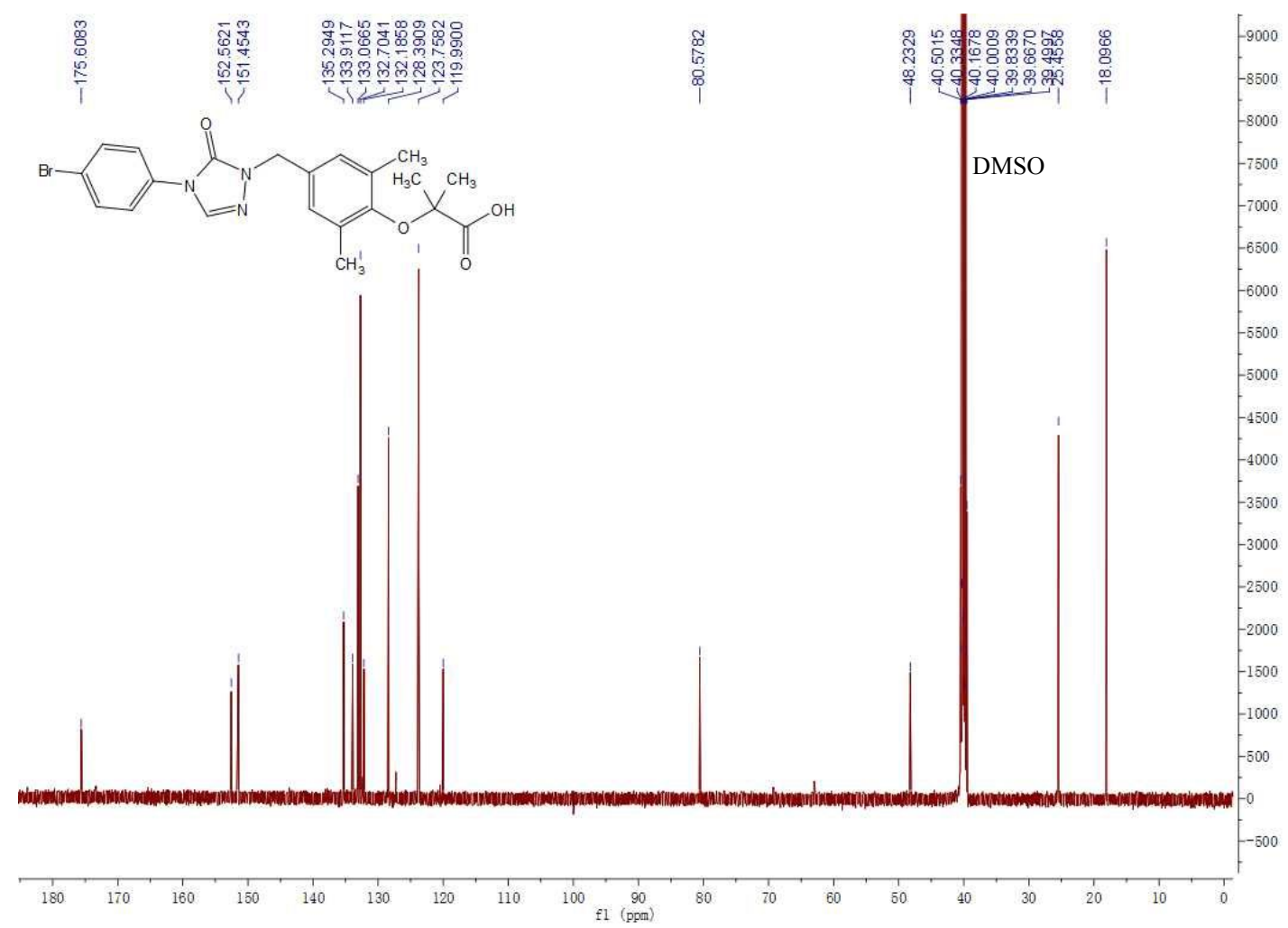


${ }^{1} \mathrm{H}-\mathrm{NMR}$ spectrum (DMSO-d6, $300 \mathrm{MHz}$ ) of H19

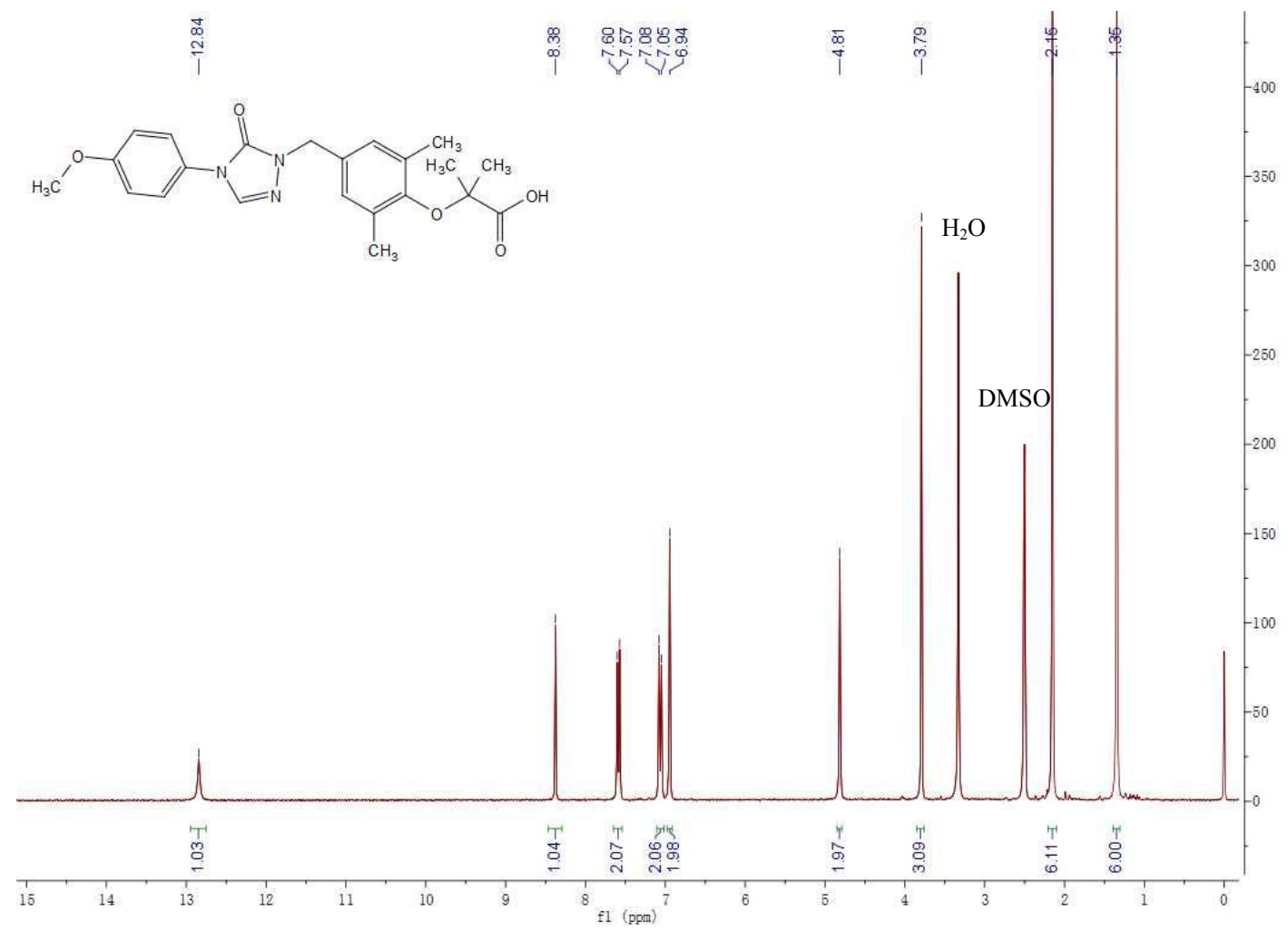

${ }^{13} \mathrm{C}-\mathrm{NMR}$ spectrum (DMSO-d6, $126 \mathrm{MHz}$ ) of $\mathrm{H} 19$

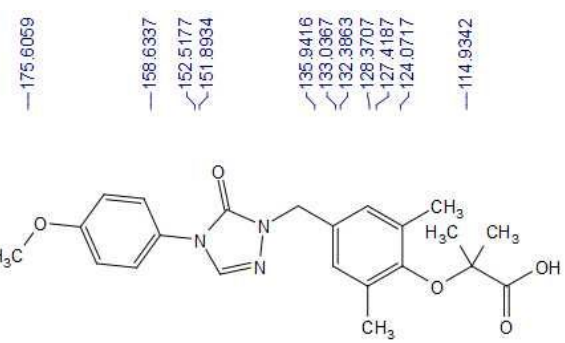

DMSO

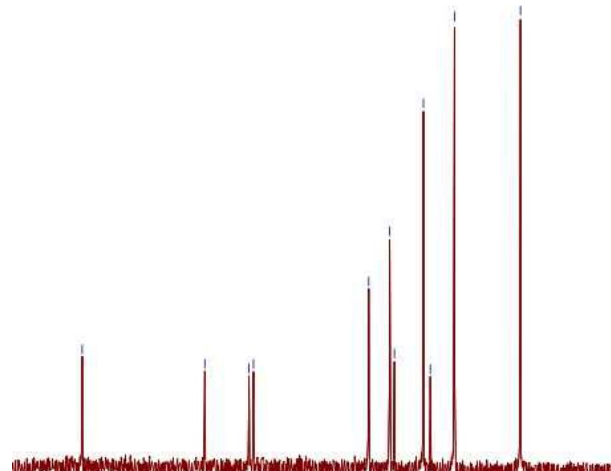


${ }^{1} \mathrm{H}-\mathrm{NMR}$ spectrum (DMSO-d6, $300 \mathrm{MHz}$ ) of $\mathrm{H} 20$

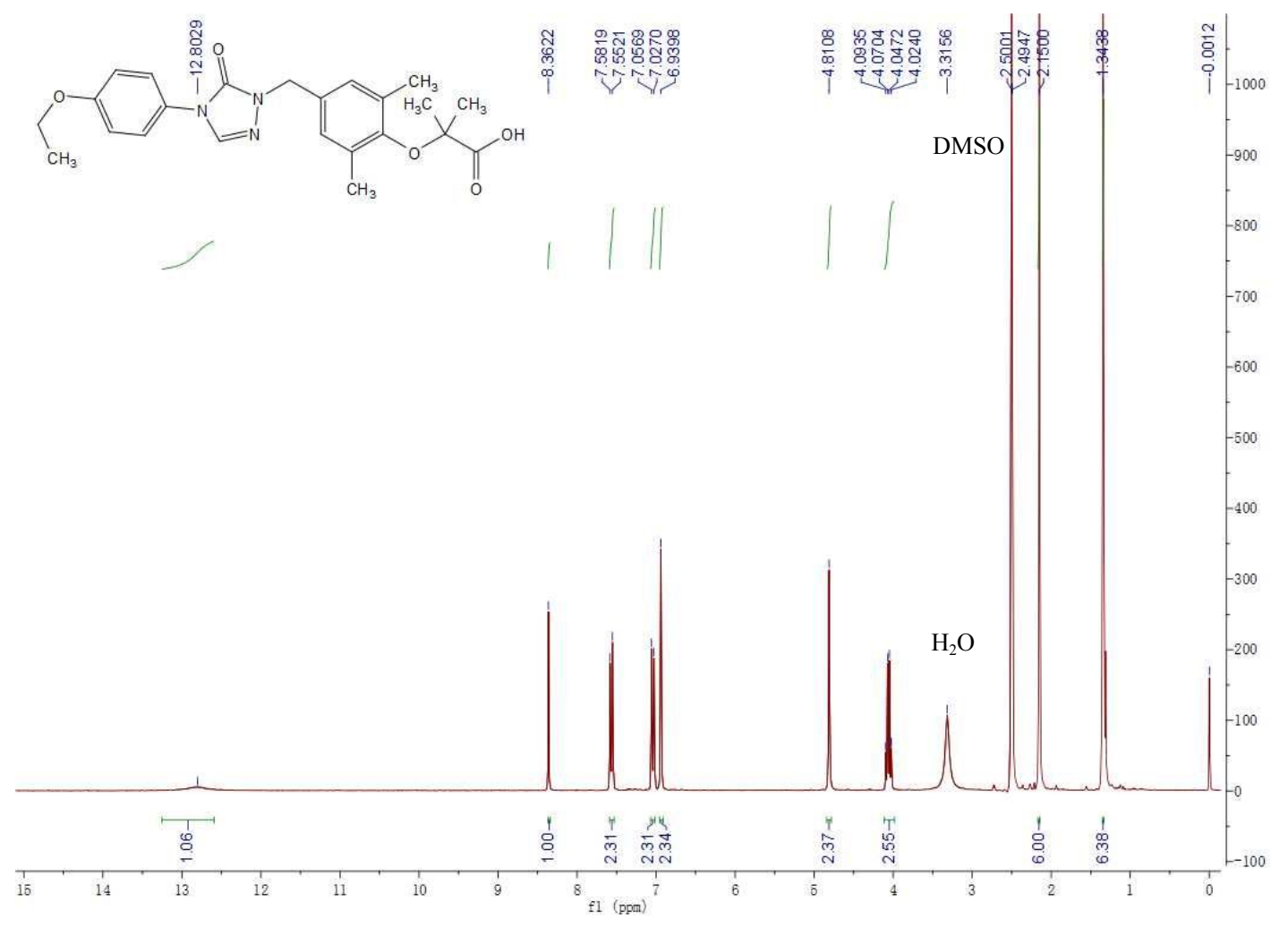

${ }^{13} \mathrm{C}-\mathrm{NMR}$ spectrum (DMSO- $d 6,126 \mathrm{MHz}$ ) of $\mathrm{H} 20$

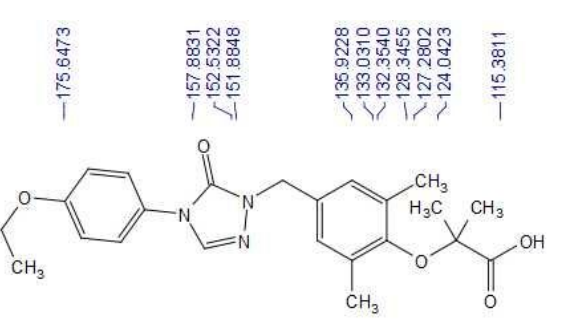

$\begin{array}{ll} & \\ & 8 \\ 0 & 8 \\ 0 & 8 \\ 0 & 8\end{array}$

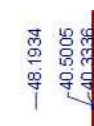

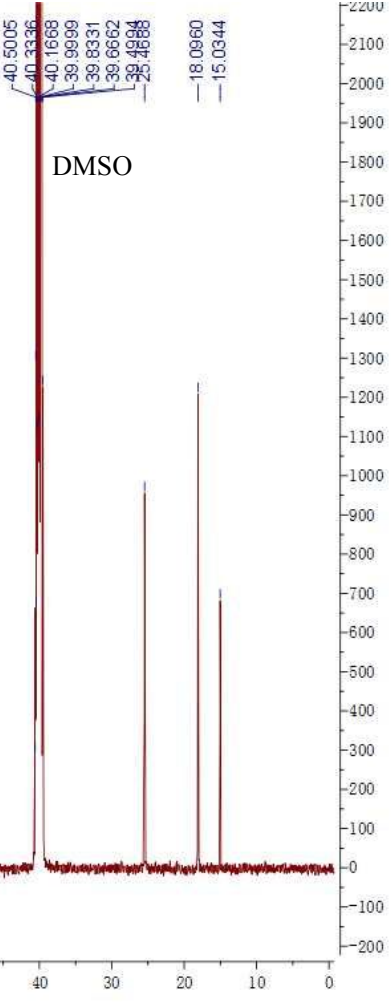

${ }^{1} \mathrm{H}-\mathrm{NMR}$ spectrum (DMSO-d6, $300 \mathrm{MHz}$ ) of $\mathrm{H} 21$ 


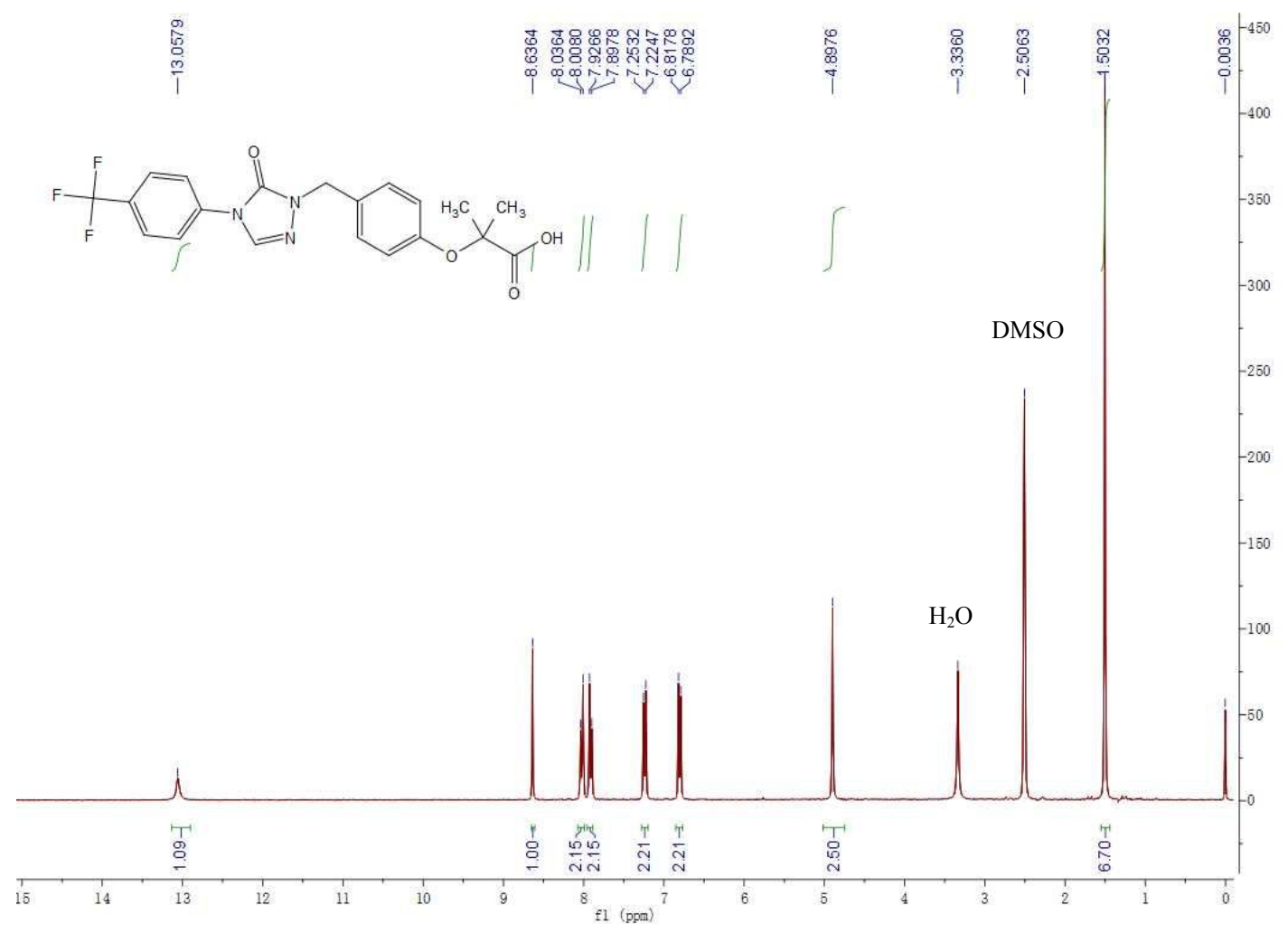

${ }^{13} \mathrm{C}-\mathrm{NMR}$ spectrum (DMSO-d6, $126 \mathrm{MHz}$ ) of $\mathrm{H} 21$

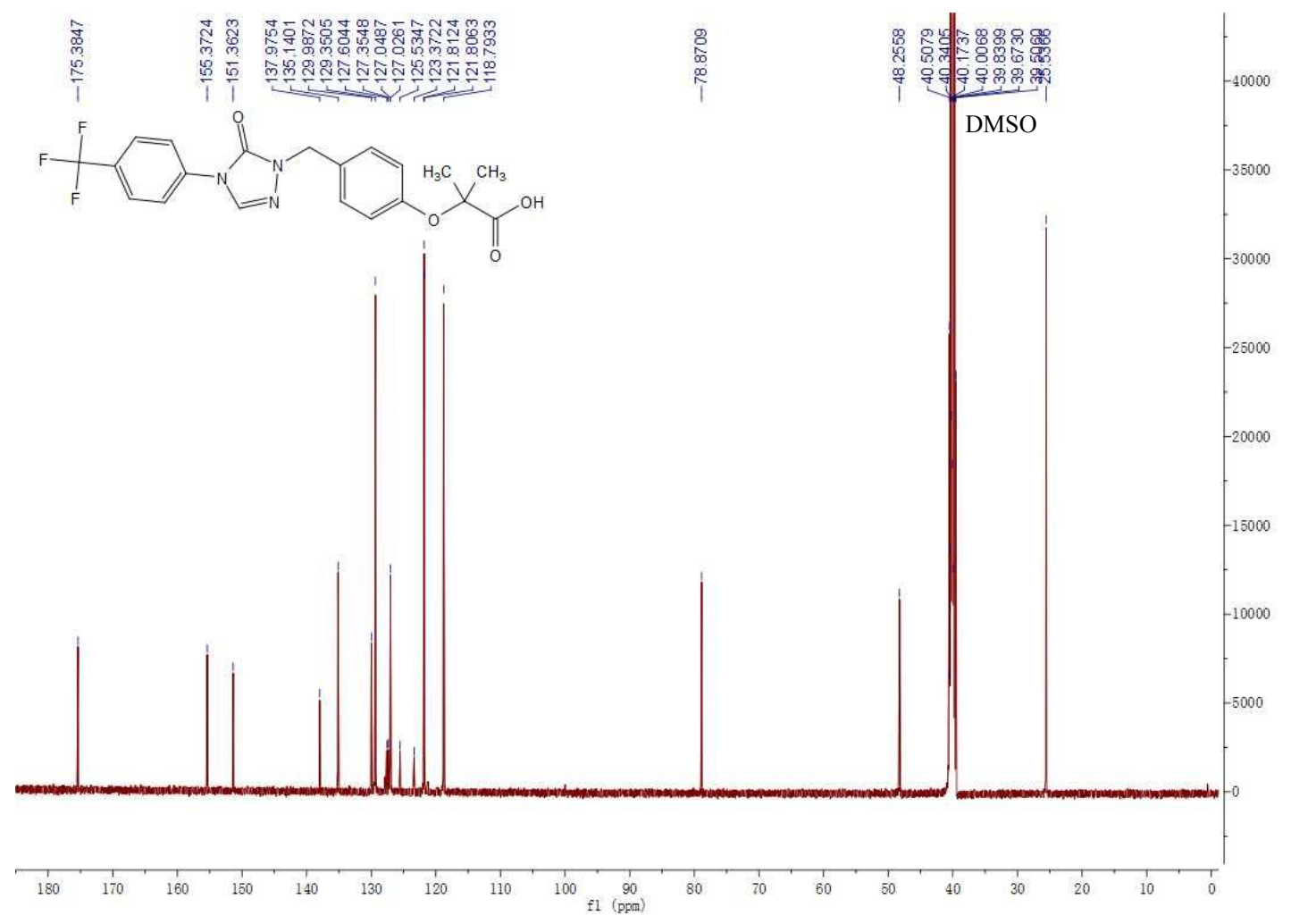


${ }^{1} \mathrm{H}-\mathrm{NMR}$ spectrum (DMSO-d6, $300 \mathrm{MHz}$ ) of $\mathrm{H} 22$

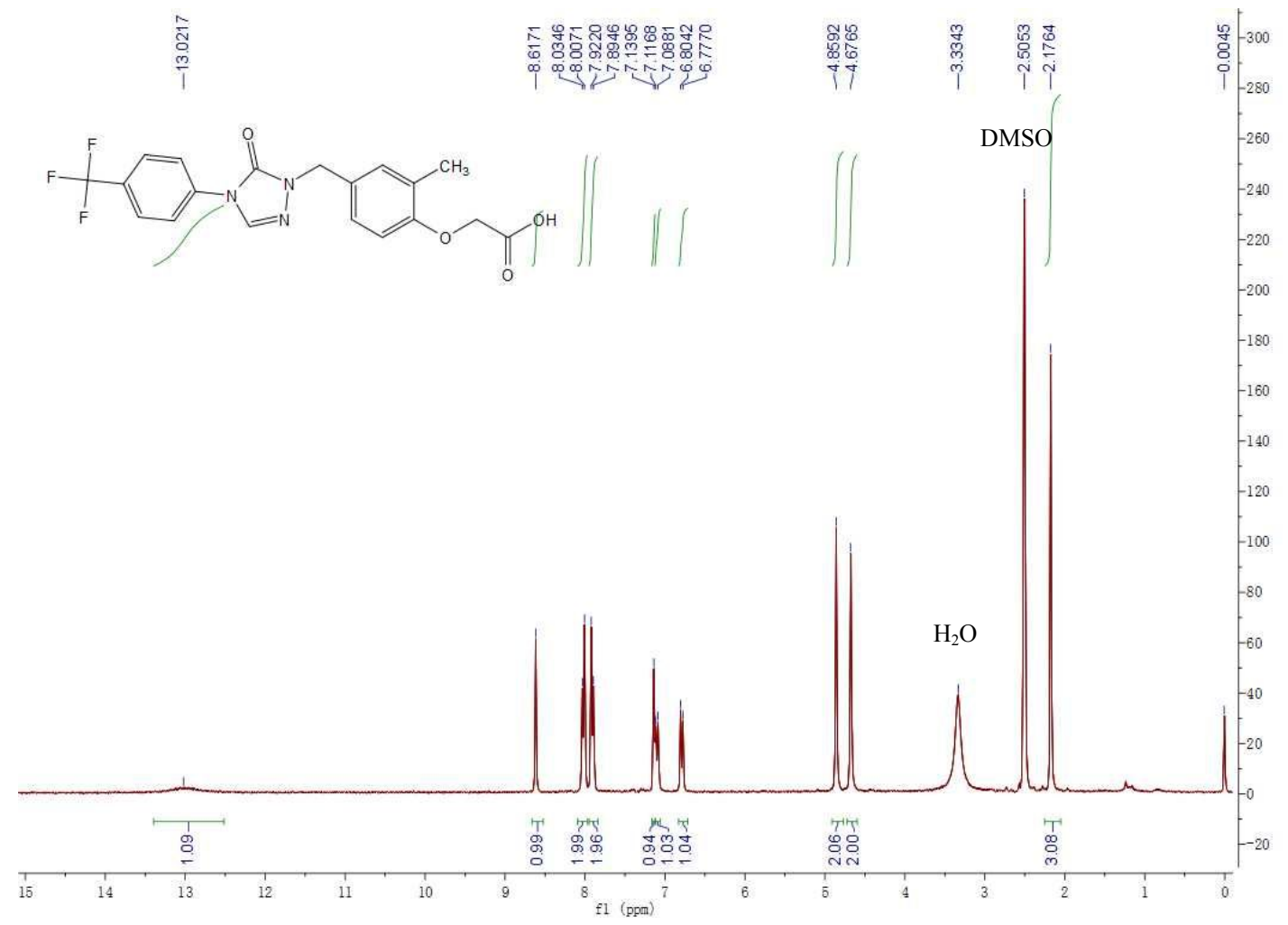

${ }^{13} \mathrm{C}-\mathrm{NMR}$ spectrum (DMSO-d6, $126 \mathrm{MHz}$ ) of $\mathrm{H} 22$

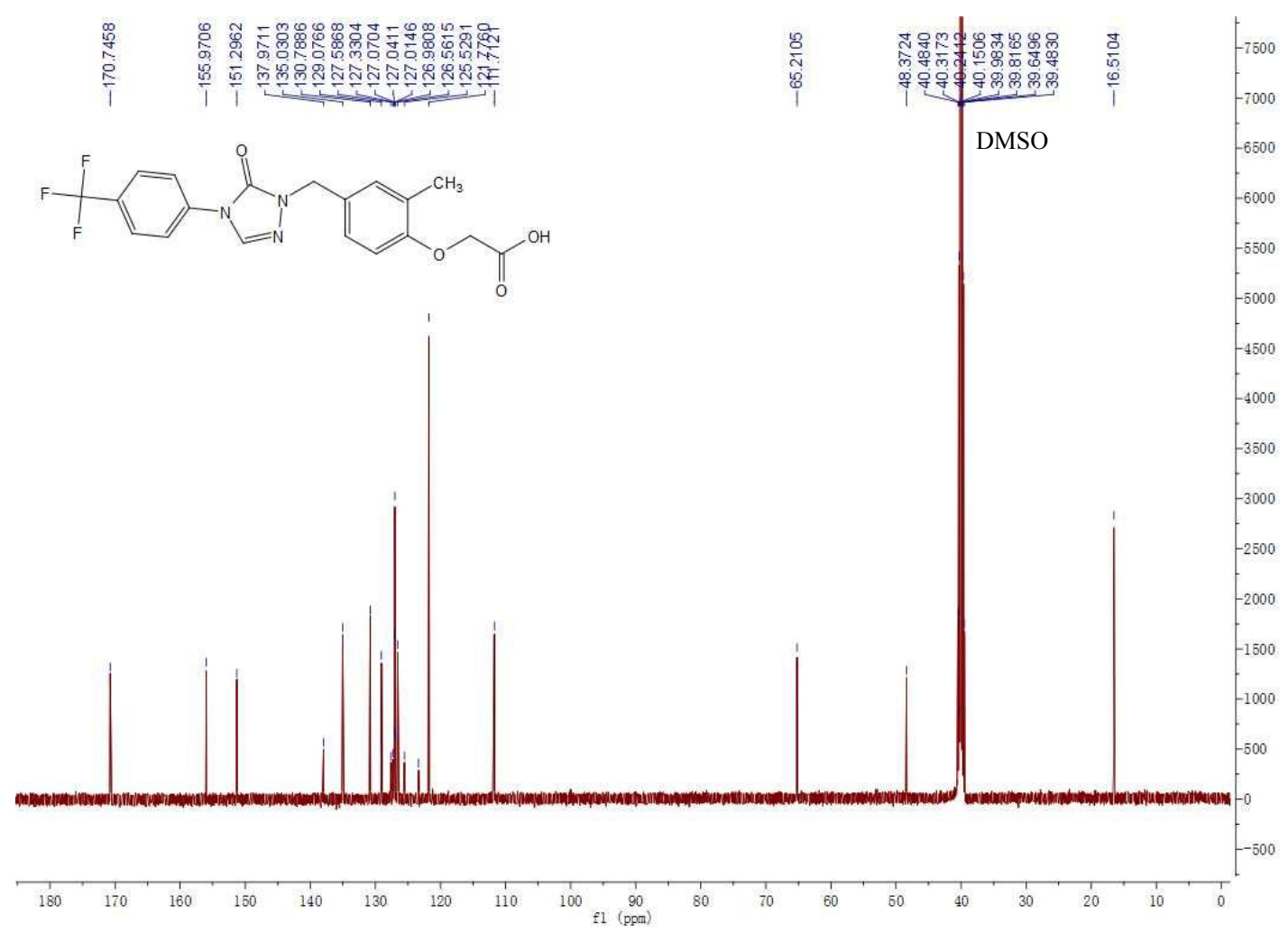


${ }^{1} \mathrm{H}-\mathrm{NMR}$ spectrum (DMSO-d6, $300 \mathrm{MHz}$ ) of $\mathrm{H} 23$

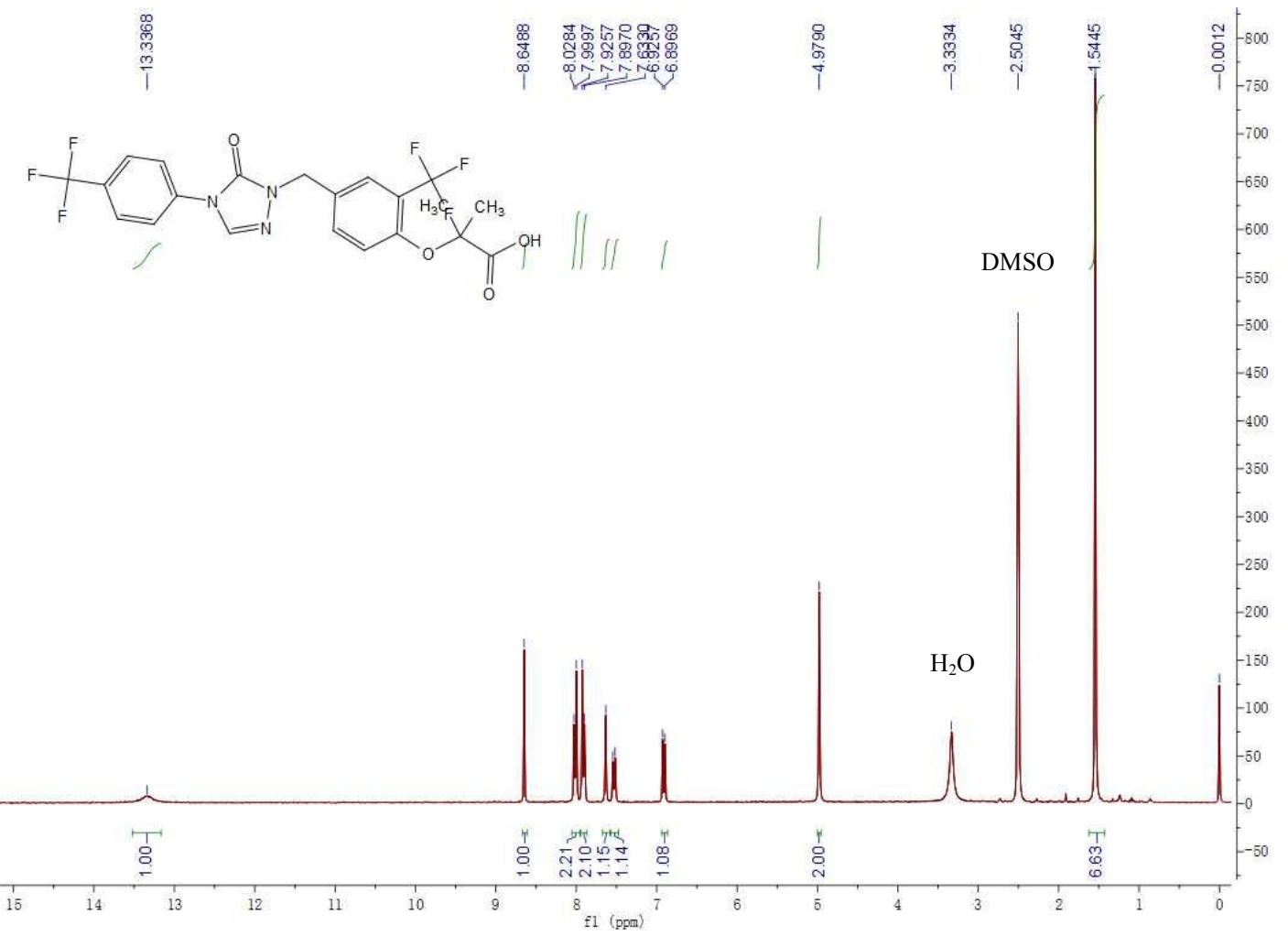

${ }^{13} \mathrm{C}-\mathrm{NMR}$ spectrum (DMSO-d6, $126 \mathrm{MHz}$ ) of $\mathrm{H} 23$

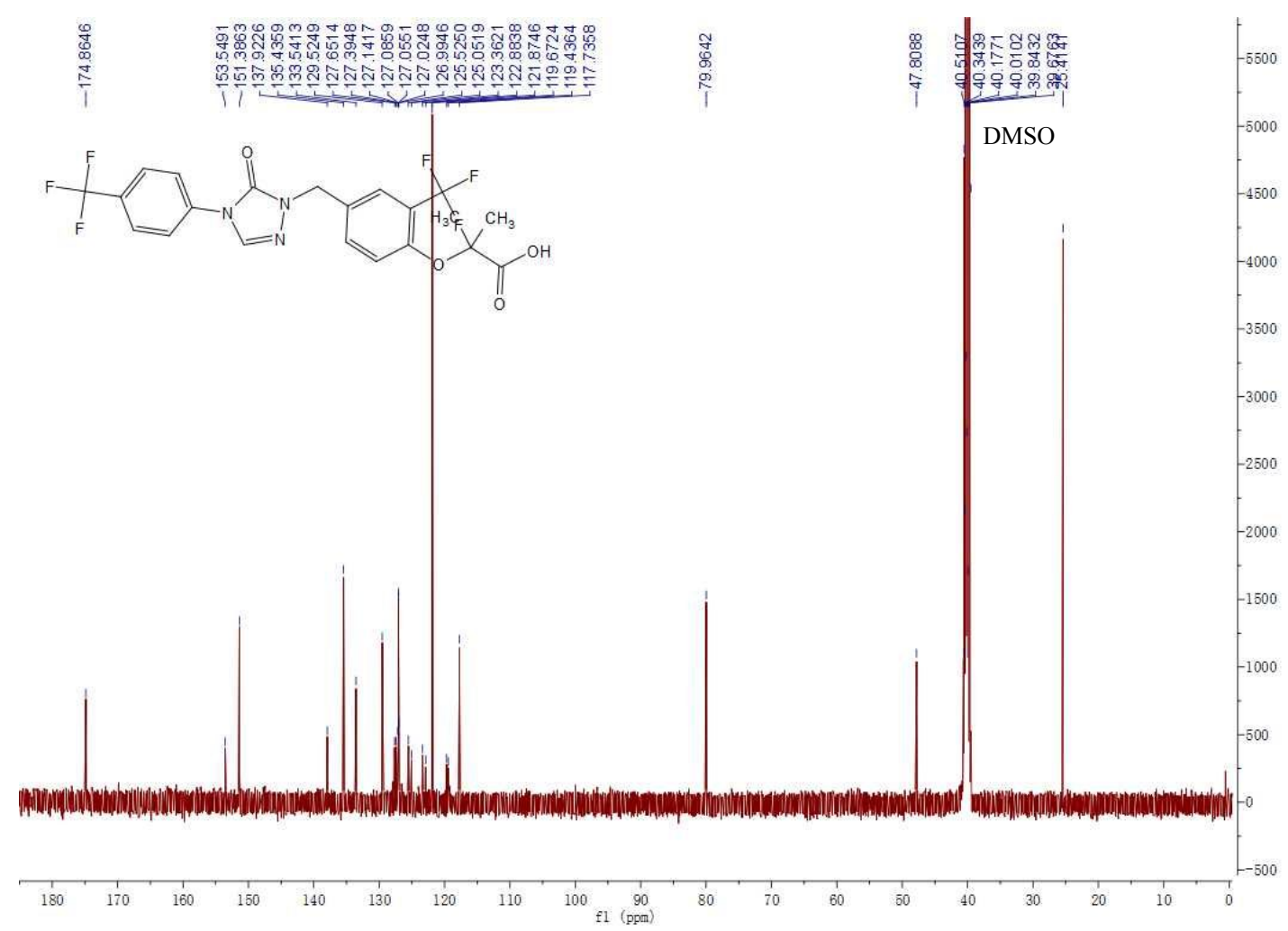


${ }^{1} \mathrm{H}-\mathrm{NMR}$ spectrum (DMSO-d6, $300 \mathrm{MHz}$ ) of $\mathrm{H} 24$

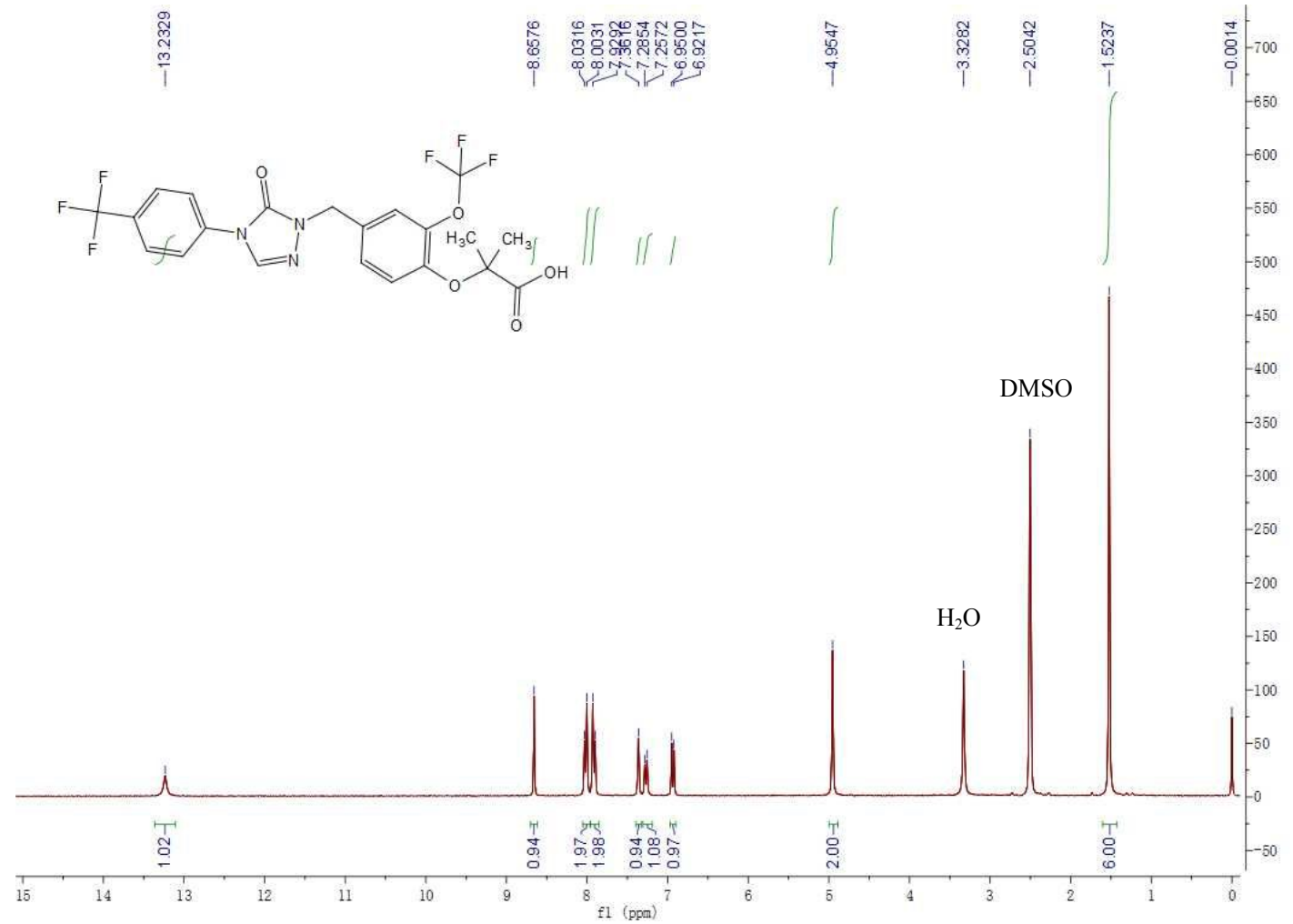

${ }^{13} \mathrm{C}-\mathrm{NMR}$ spectrum (DMSO-d6, $126 \mathrm{MHz}$ ) of $\mathrm{H} 24$

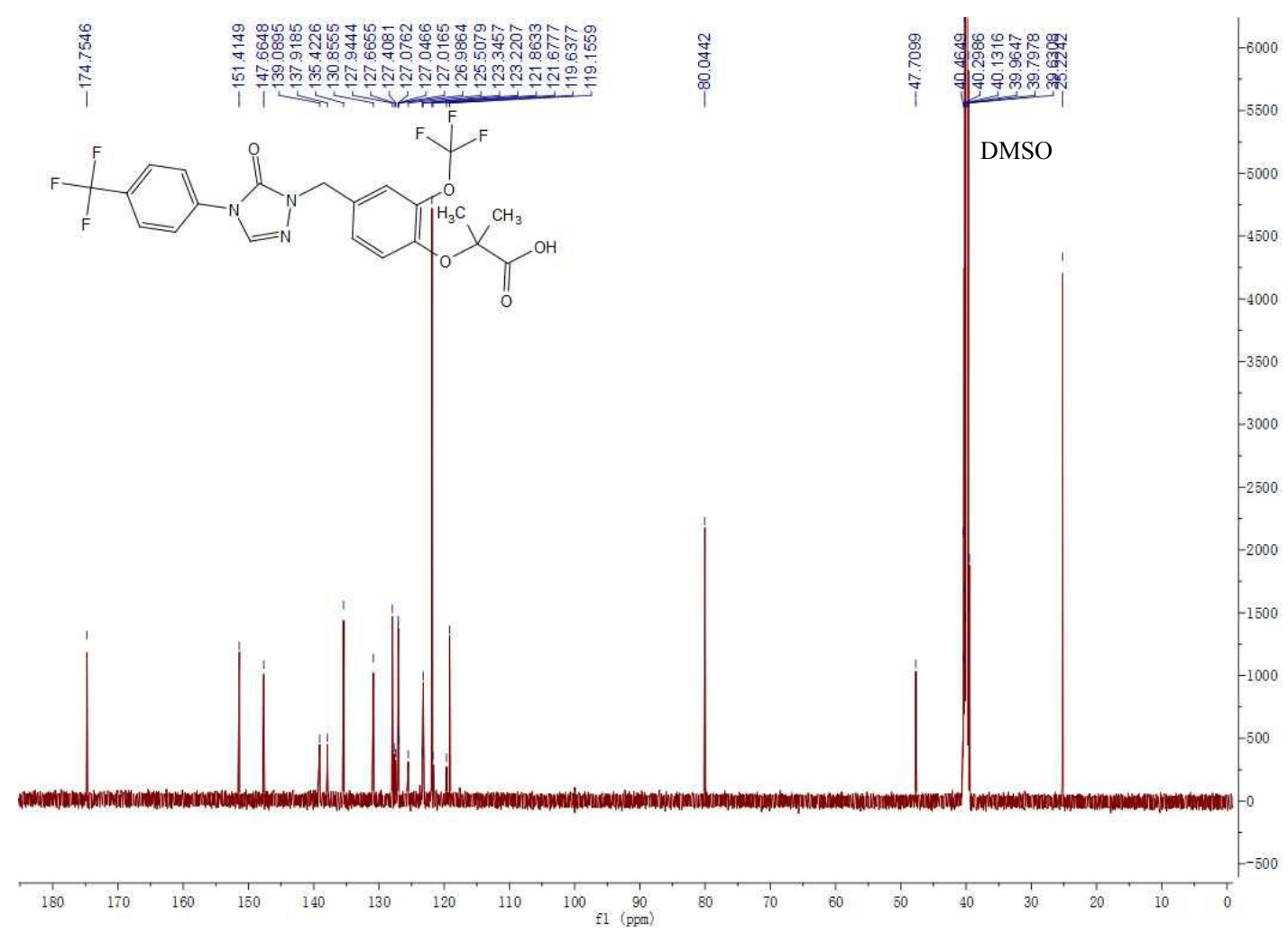


${ }^{1} \mathrm{H}-\mathrm{NMR}$ spectrum (DMSO-d6, $300 \mathrm{MHz}$ ) of $\mathrm{H} 25$

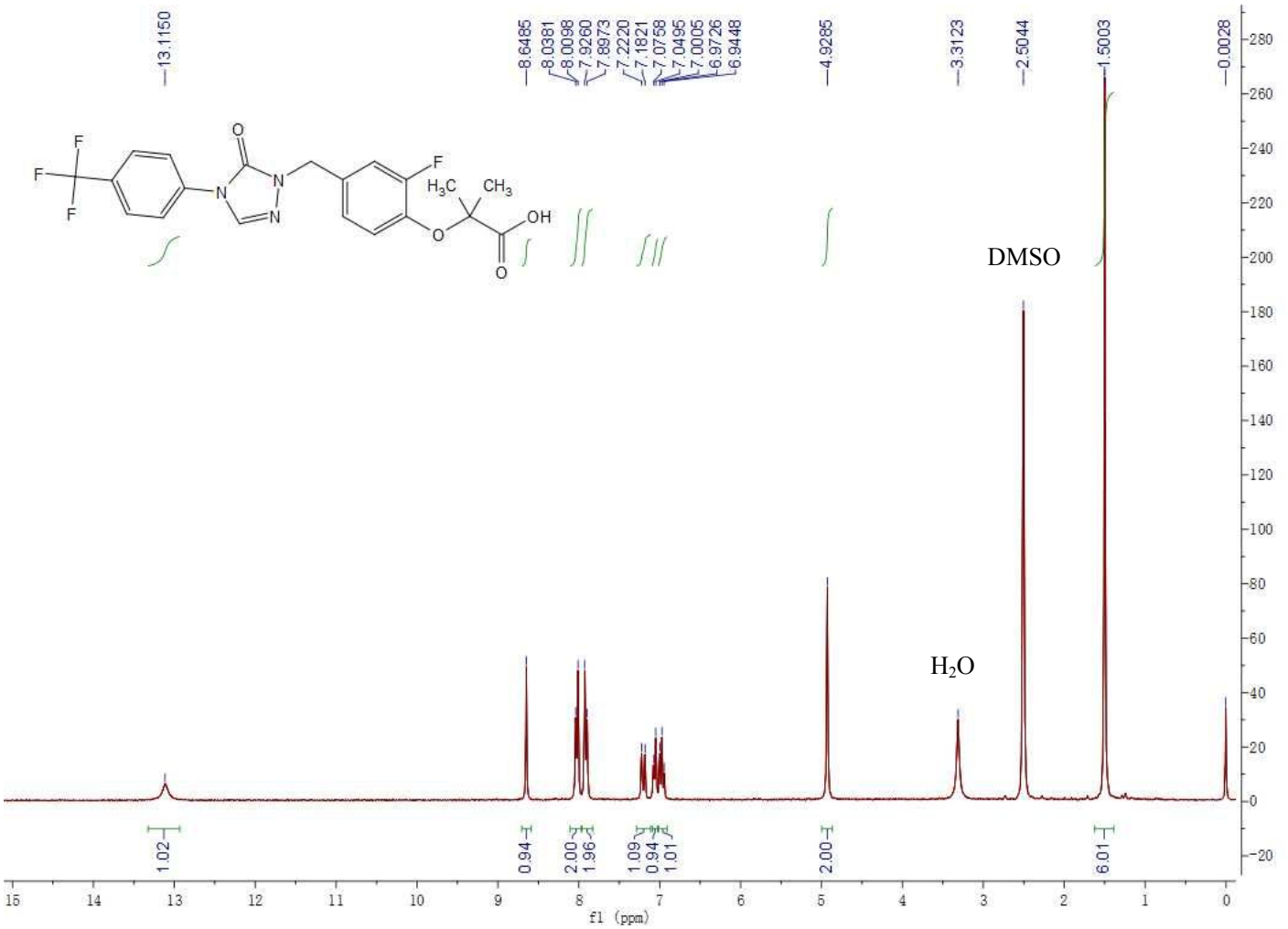

${ }^{13} \mathrm{C}-\mathrm{NMR}$ spectrum (DMSO-d6, $126 \mathrm{MHz}$ ) of $\mathrm{H} 25$

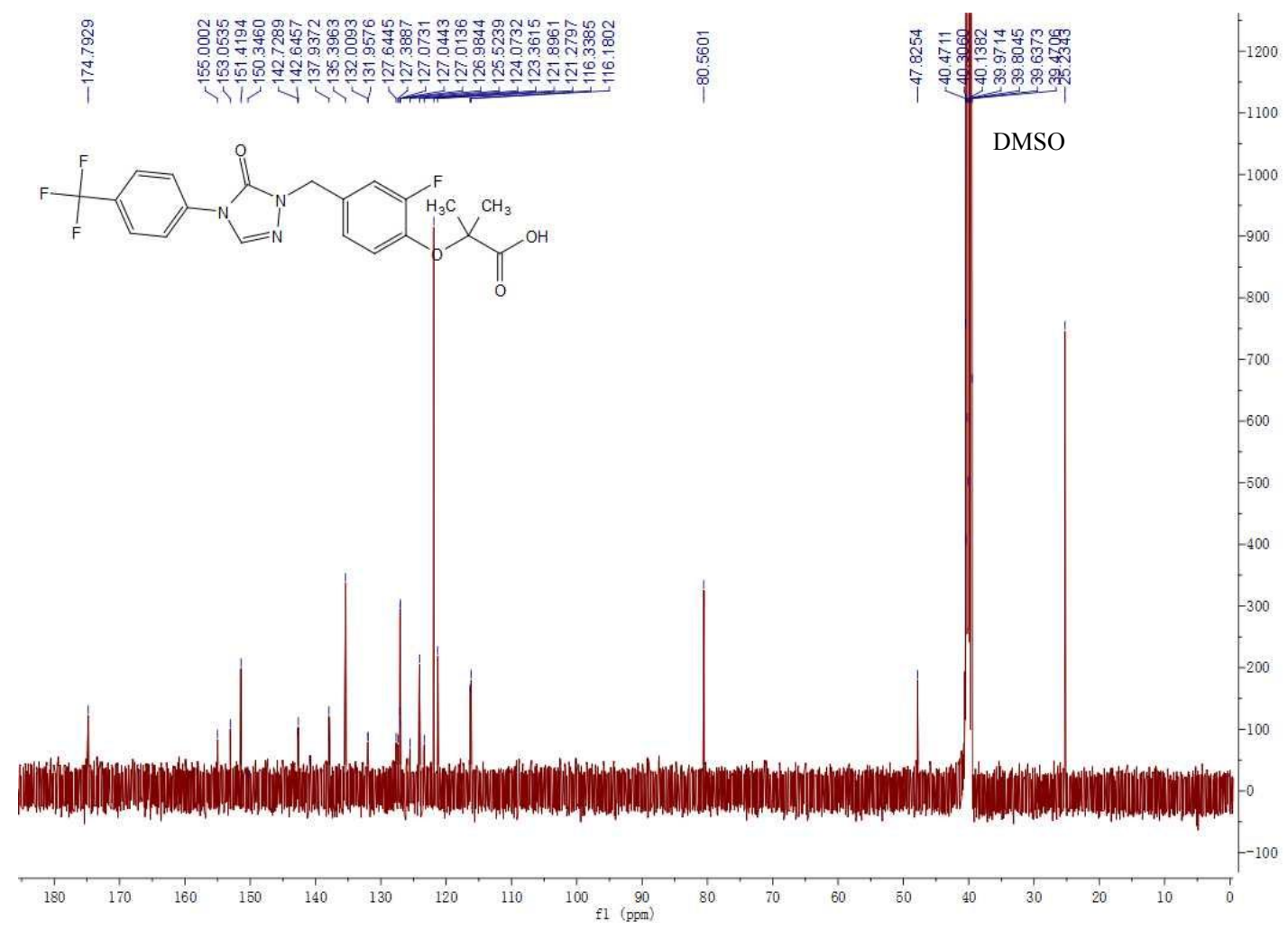


${ }^{1} \mathrm{H}-\mathrm{NMR}$ spectrum (DMSO-d6, $300 \mathrm{MHz}$ ) of $\mathrm{H} 26$

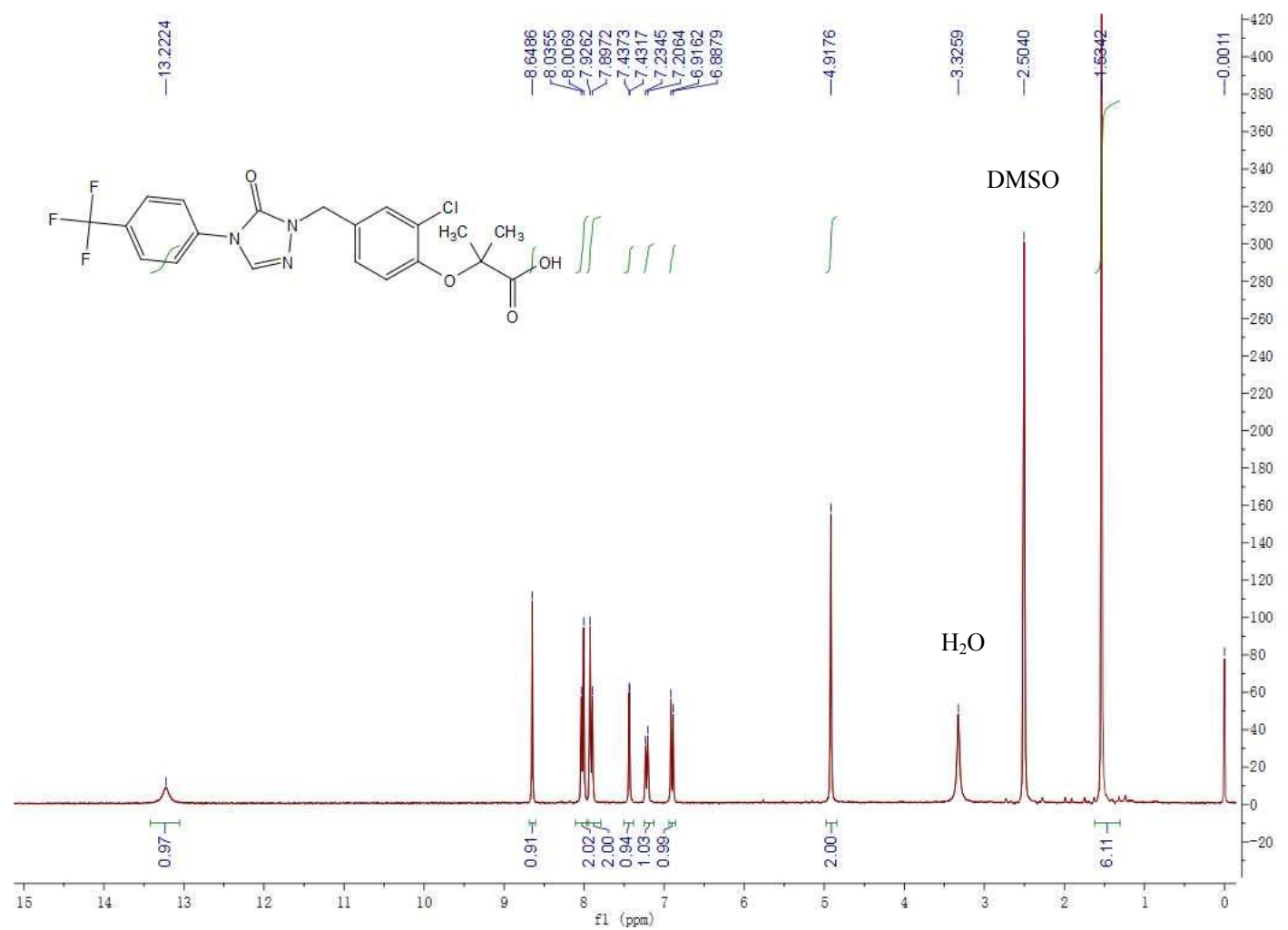

${ }^{13} \mathrm{C}-\mathrm{NMR}$ spectrum (DMSO-d6, $126 \mathrm{MHz}$ ) of H26

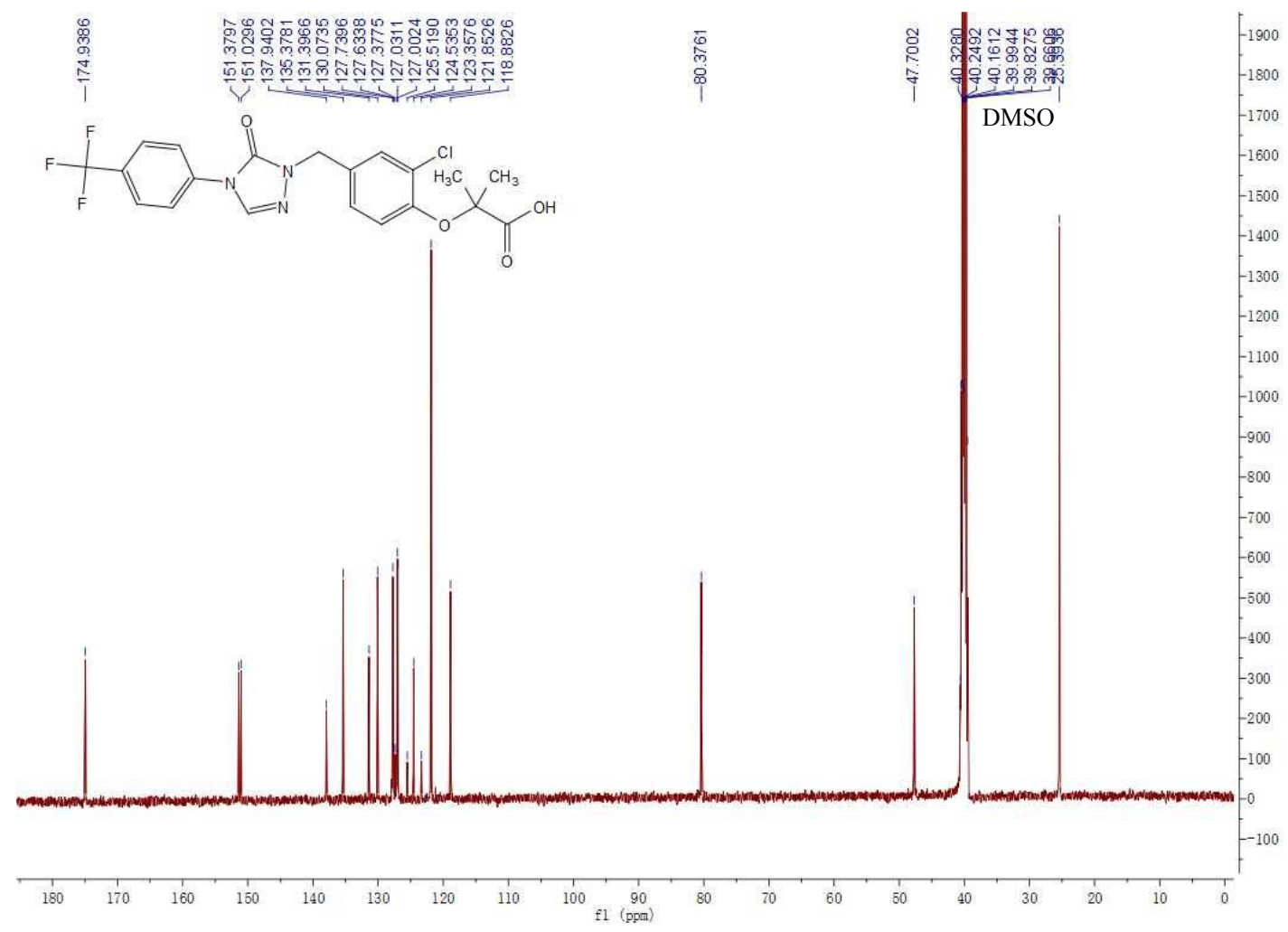


${ }^{1} \mathrm{H}-\mathrm{NMR}$ spectrum (DMSO-d6, $300 \mathrm{MHz}$ ) of $\mathrm{H} 27$

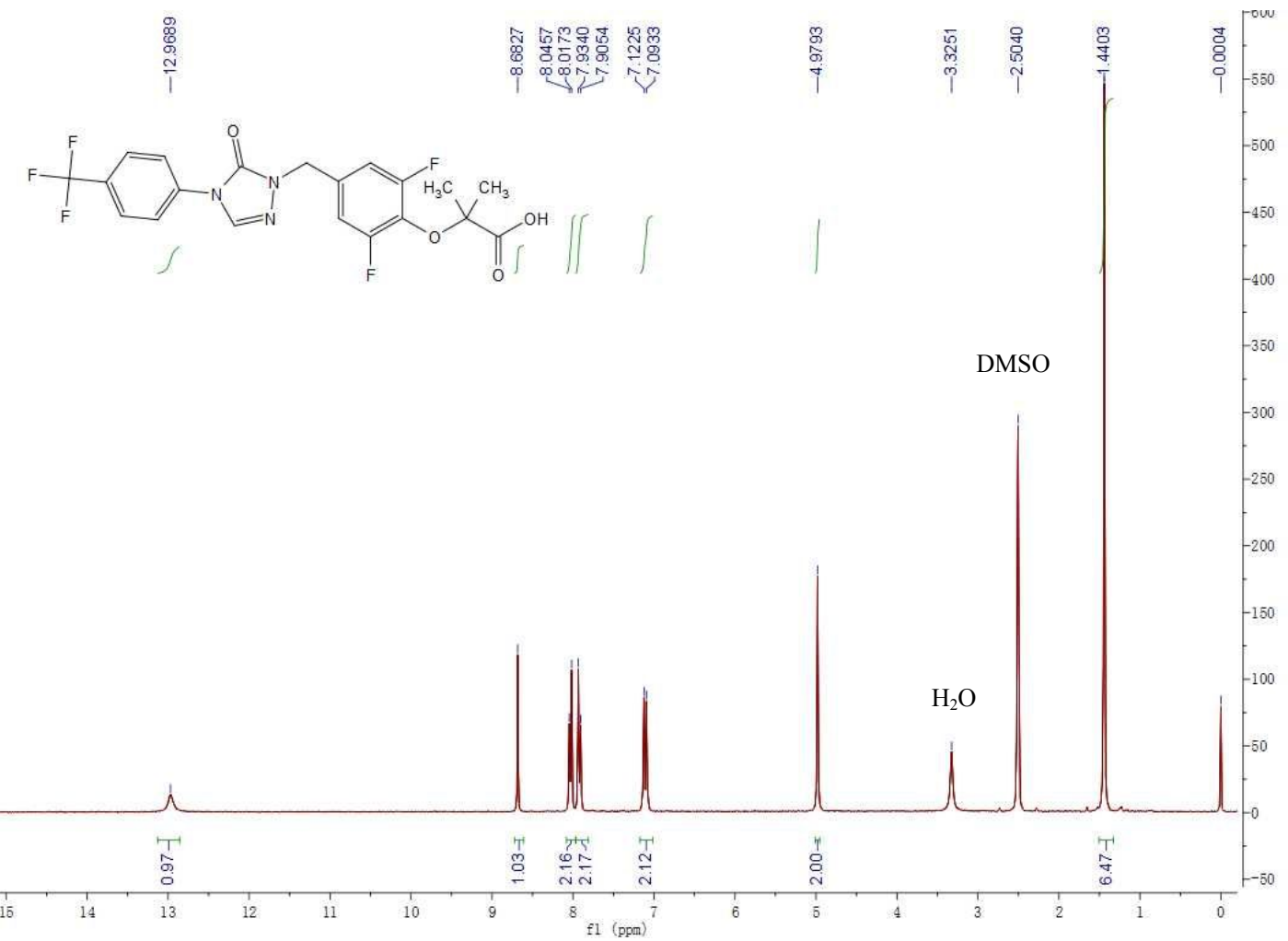

${ }^{13} \mathrm{C}-\mathrm{NMR}$ spectrum (DMSO-d6, $126 \mathrm{MHz}$ ) of $\mathrm{H} 27$

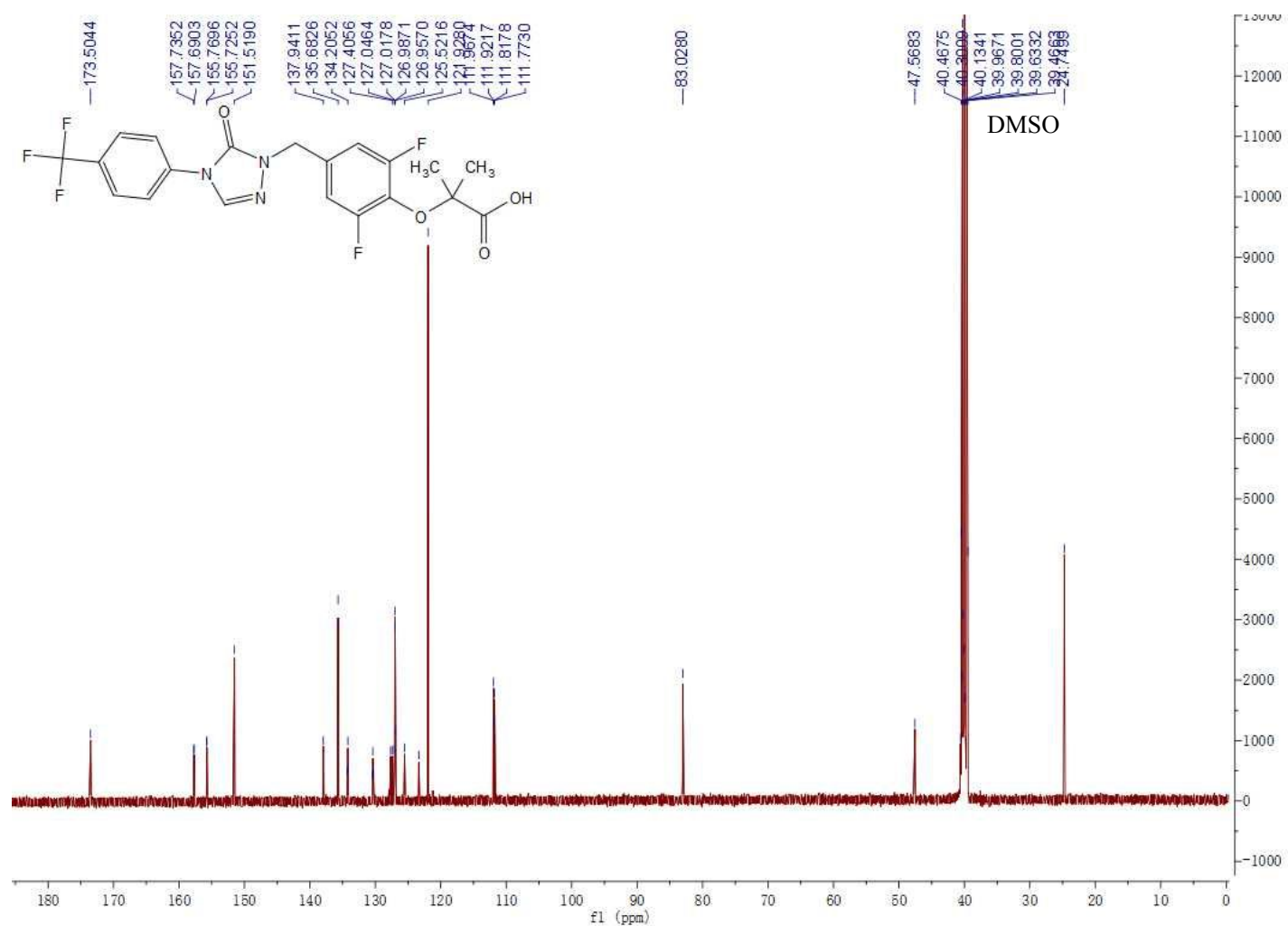


${ }^{1} \mathrm{H}-\mathrm{NMR}$ spectrum (DMSO-d6, $300 \mathrm{MHz}$ ) of $\mathrm{H} 28$

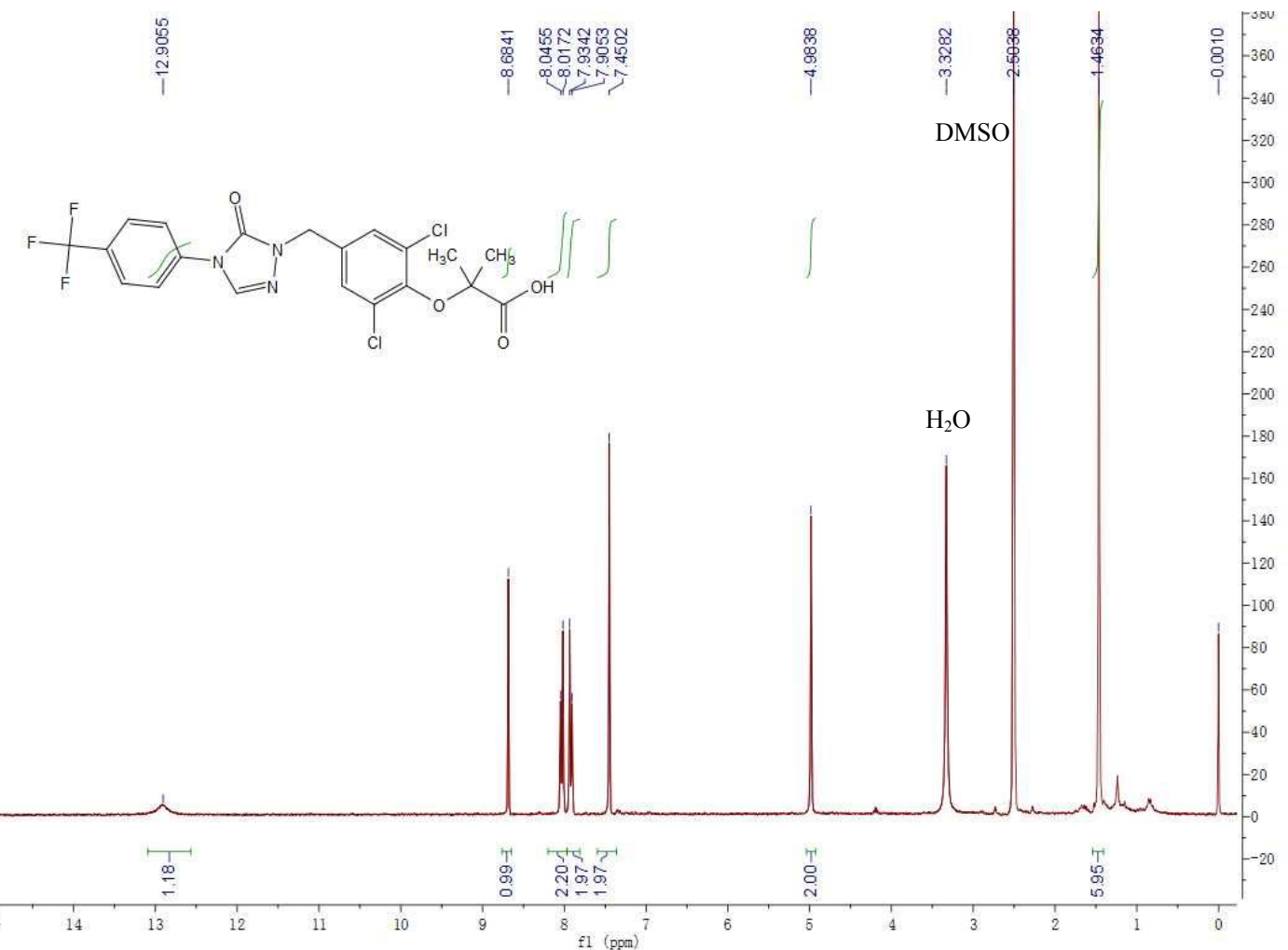

${ }^{13} \mathrm{C}-\mathrm{NMR}$ spectrum (DMSO-d6, $126 \mathrm{MHz}$ ) of $\mathrm{H} 28$

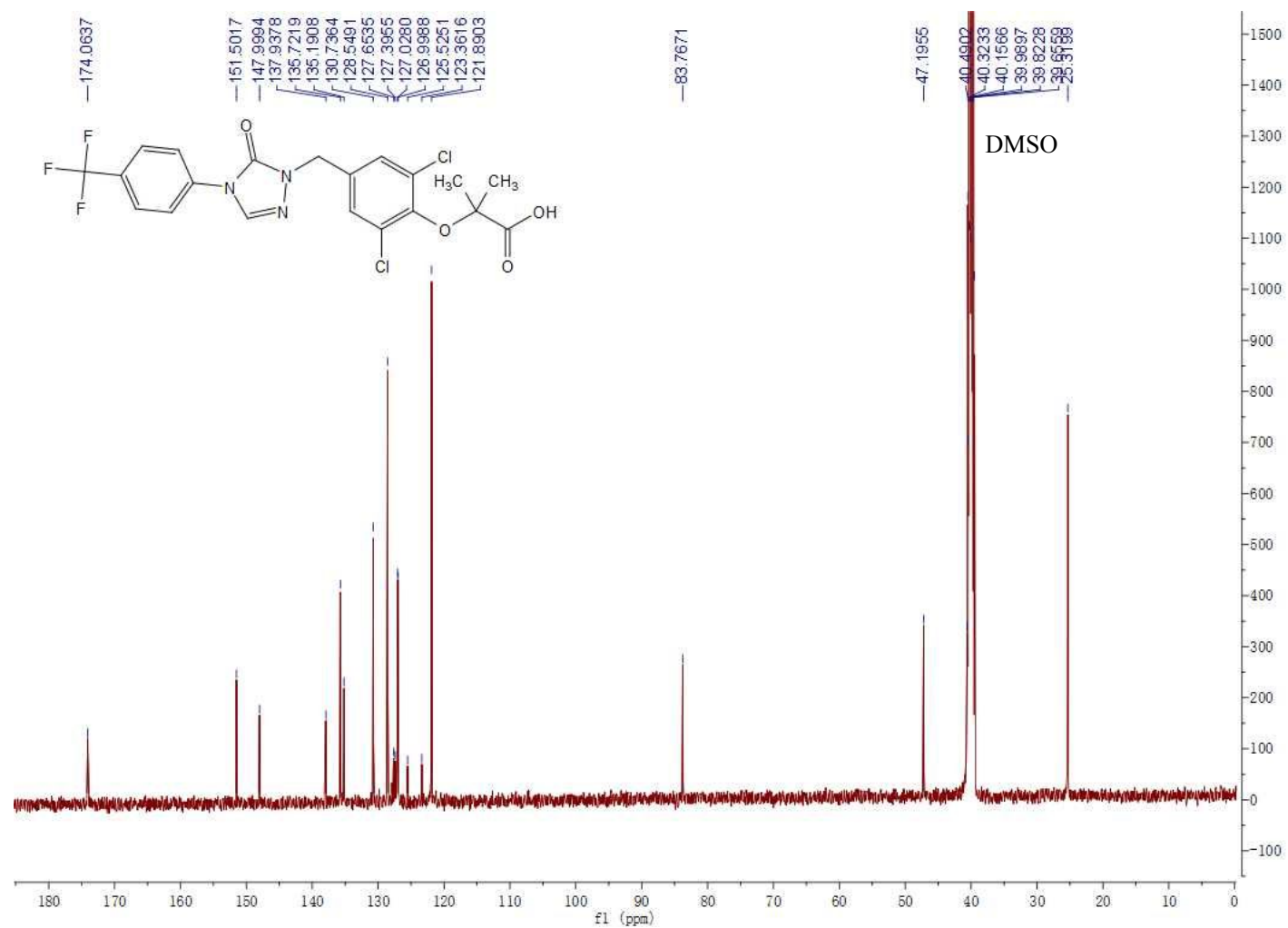


${ }^{1} \mathrm{H}-\mathrm{NMR}$ spectrum (DMSO-d6, $300 \mathrm{MHz}$ ) of $\mathrm{H} 29$

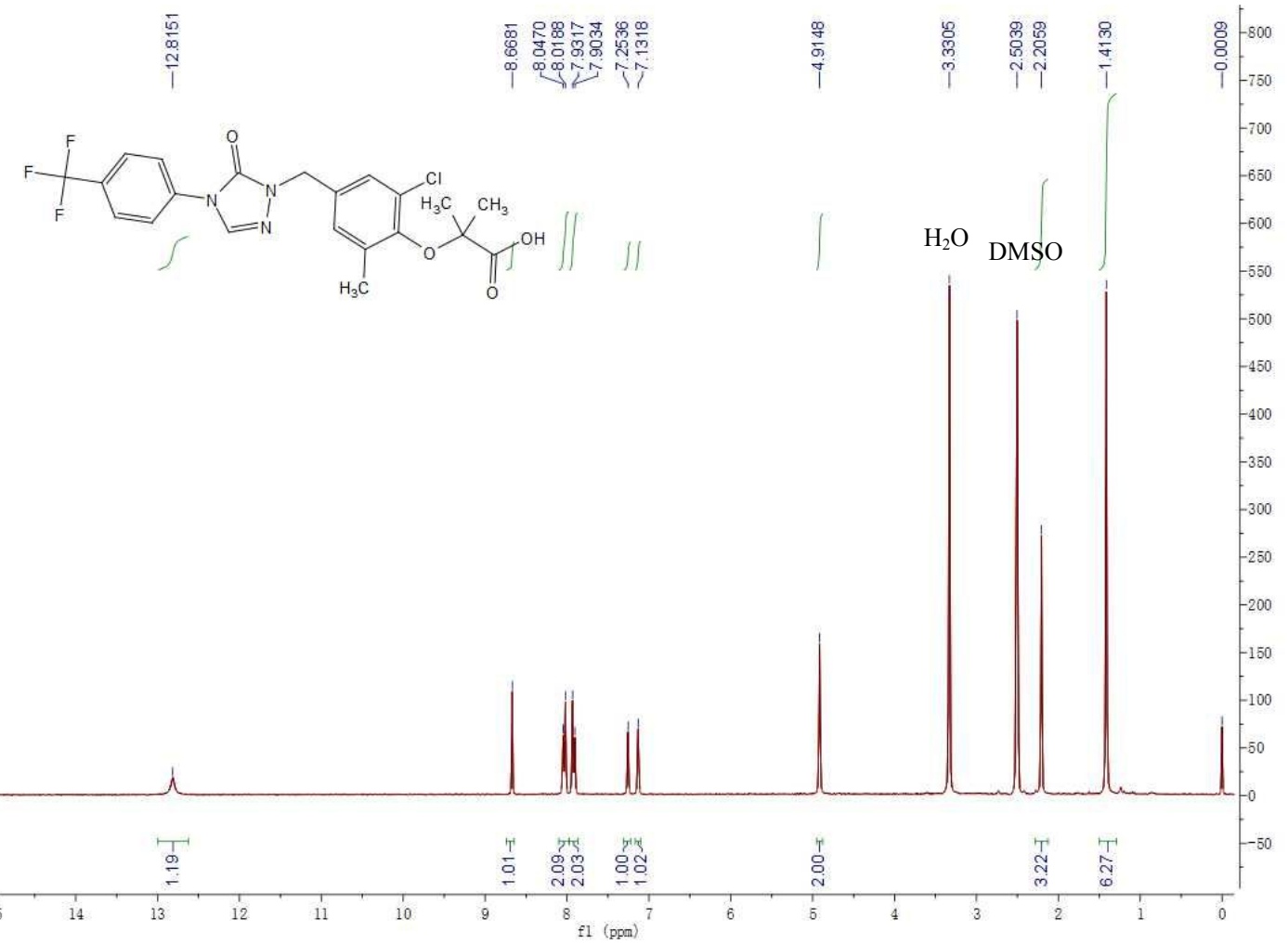

${ }^{13} \mathrm{C}-\mathrm{NMR}$ spectrum (DMSO-d6, $126 \mathrm{MHz}$ ) of $\mathrm{H} 29$
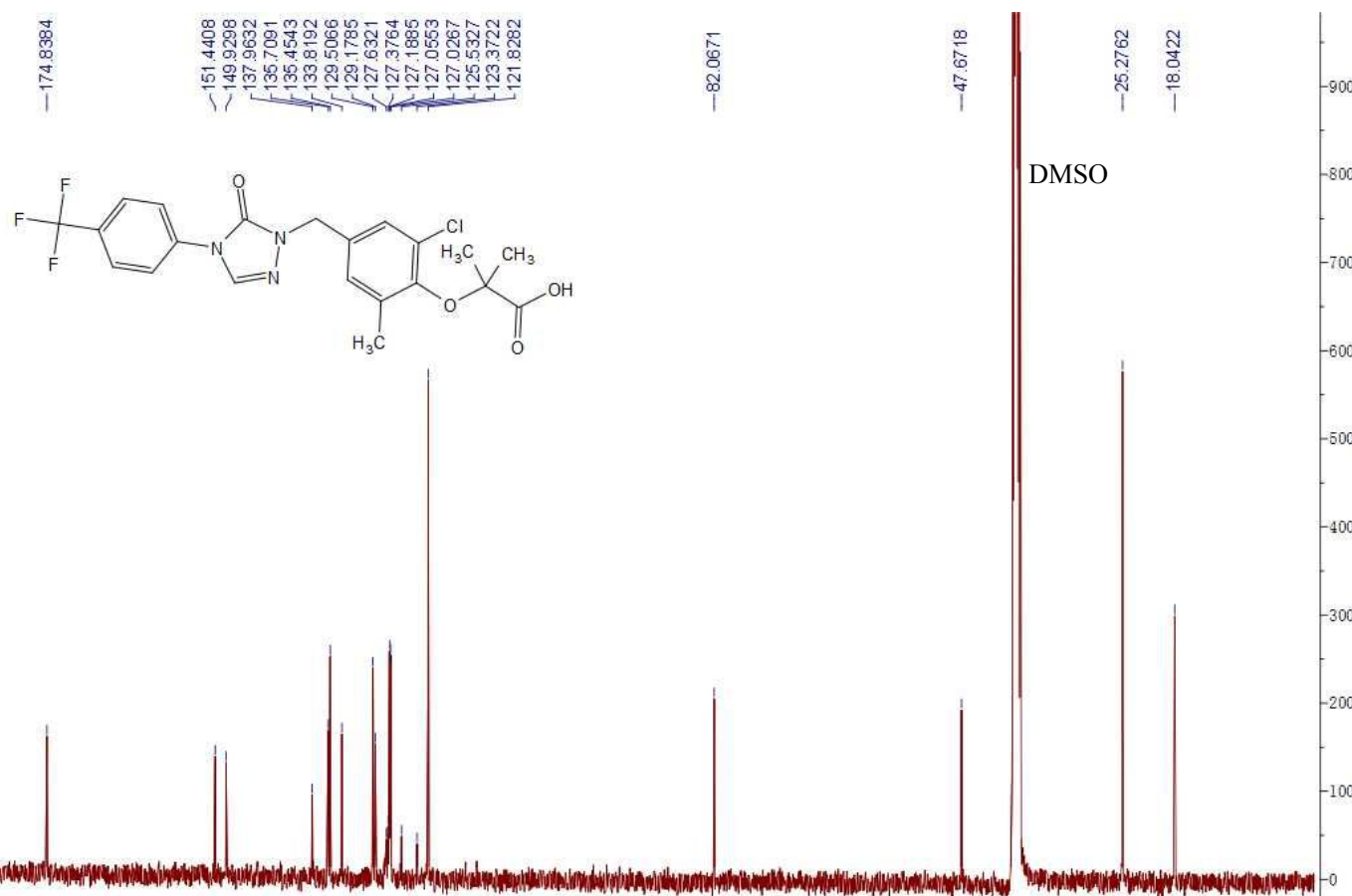

$\begin{array}{llllllllll}180 & 170 & 160 & 150 & 140 & 130 & 120 & 110 & 100 & 90 \\ \mathrm{f} 1(\mathrm{ppm})\end{array}$ 
${ }^{1} \mathrm{H}-\mathrm{NMR}$ spectrum (DMSO-d6, $300 \mathrm{MHz}$ ) of H30

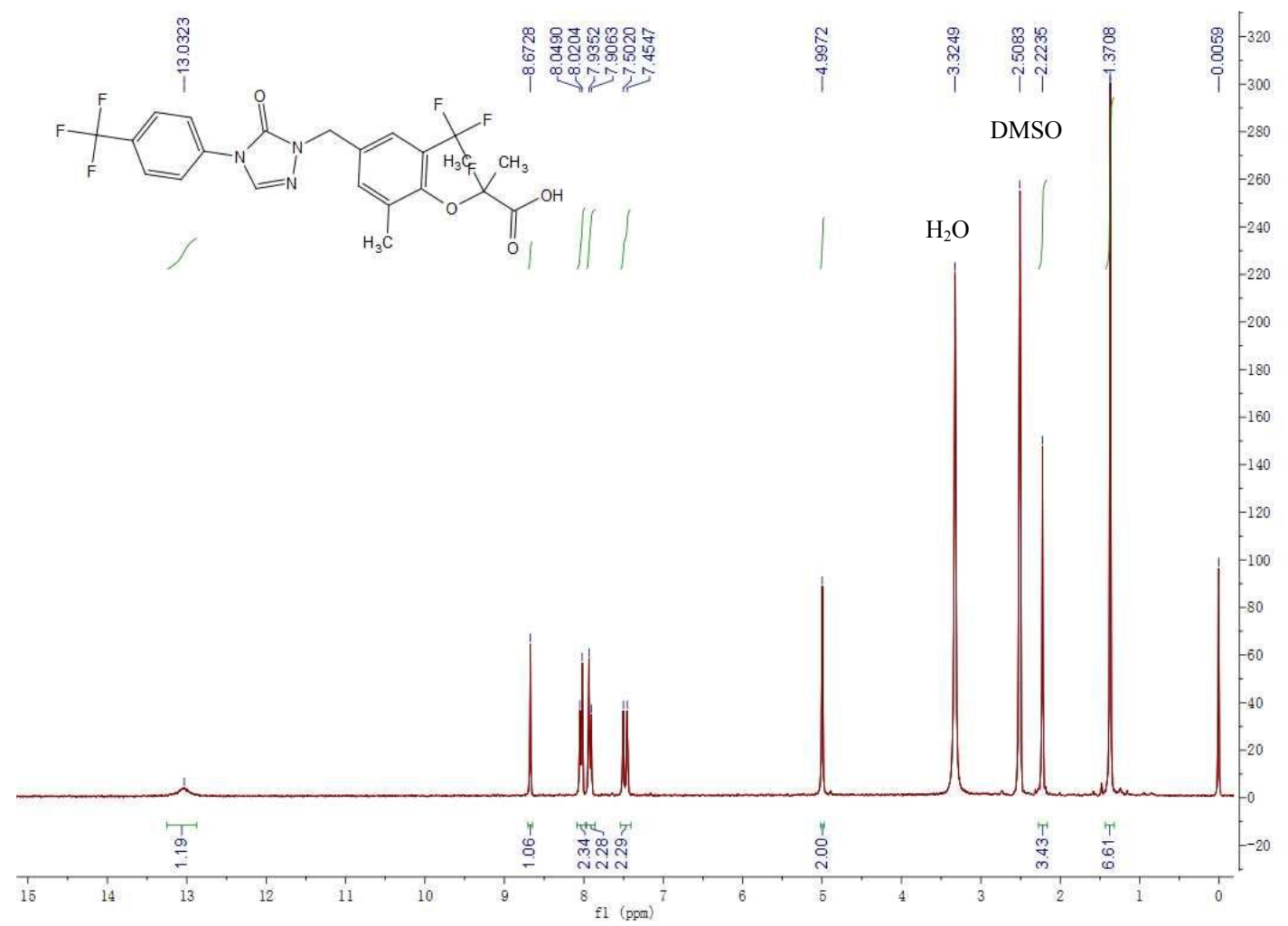

${ }^{13} \mathrm{C}-\mathrm{NMR}$ spectrum (DMSO-d6, $126 \mathrm{MHz}$ ) of H30

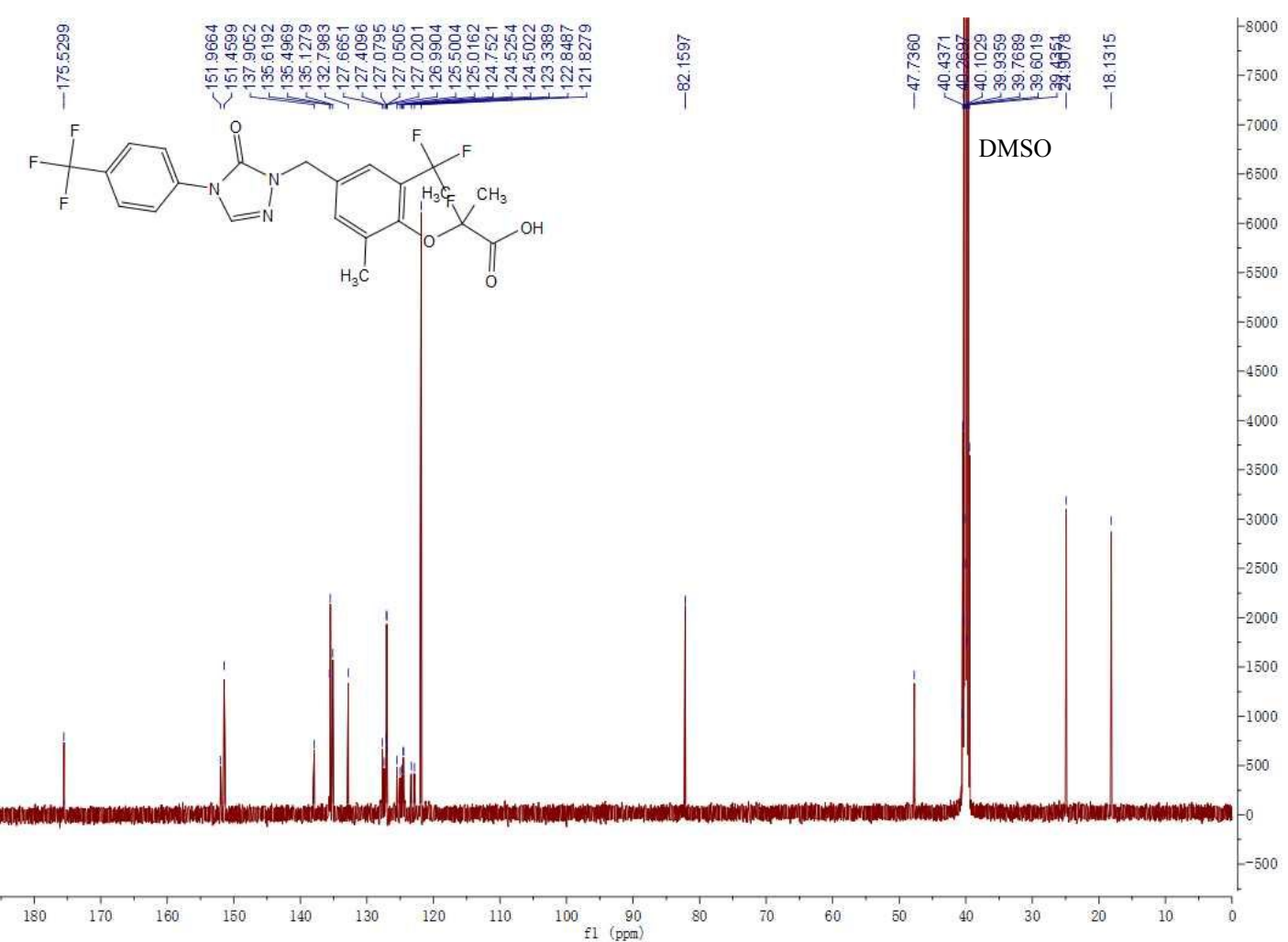


${ }^{1} \mathrm{H}-\mathrm{NMR}$ spectrum (DMSO-d6, $300 \mathrm{MHz}$ ) of H31

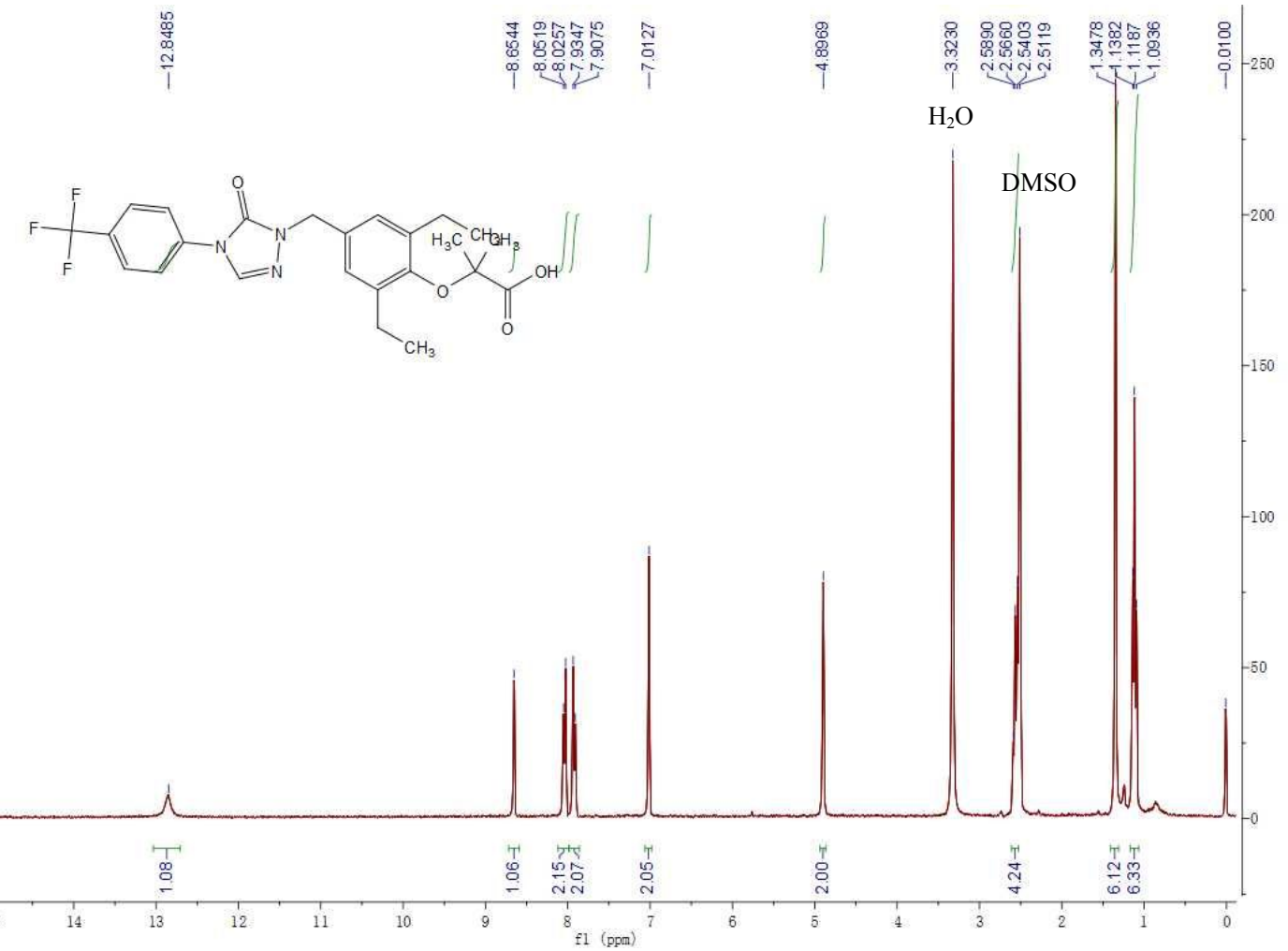

${ }^{13} \mathrm{C}-\mathrm{NMR}$ spectrum (DMSO-d6, $126 \mathrm{MHz}$ ) of $\mathrm{H} 31$
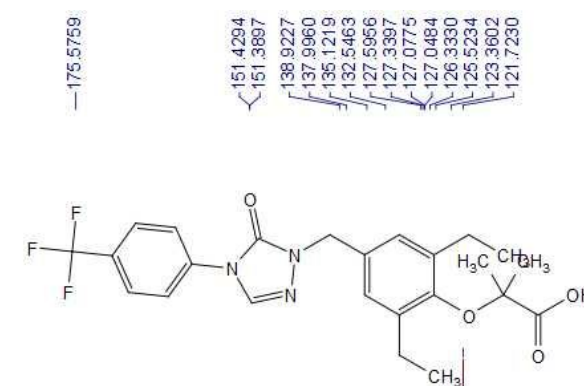

8
8
8
8
1

离

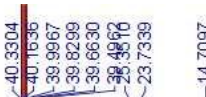

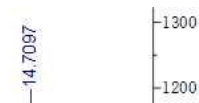
DMSO

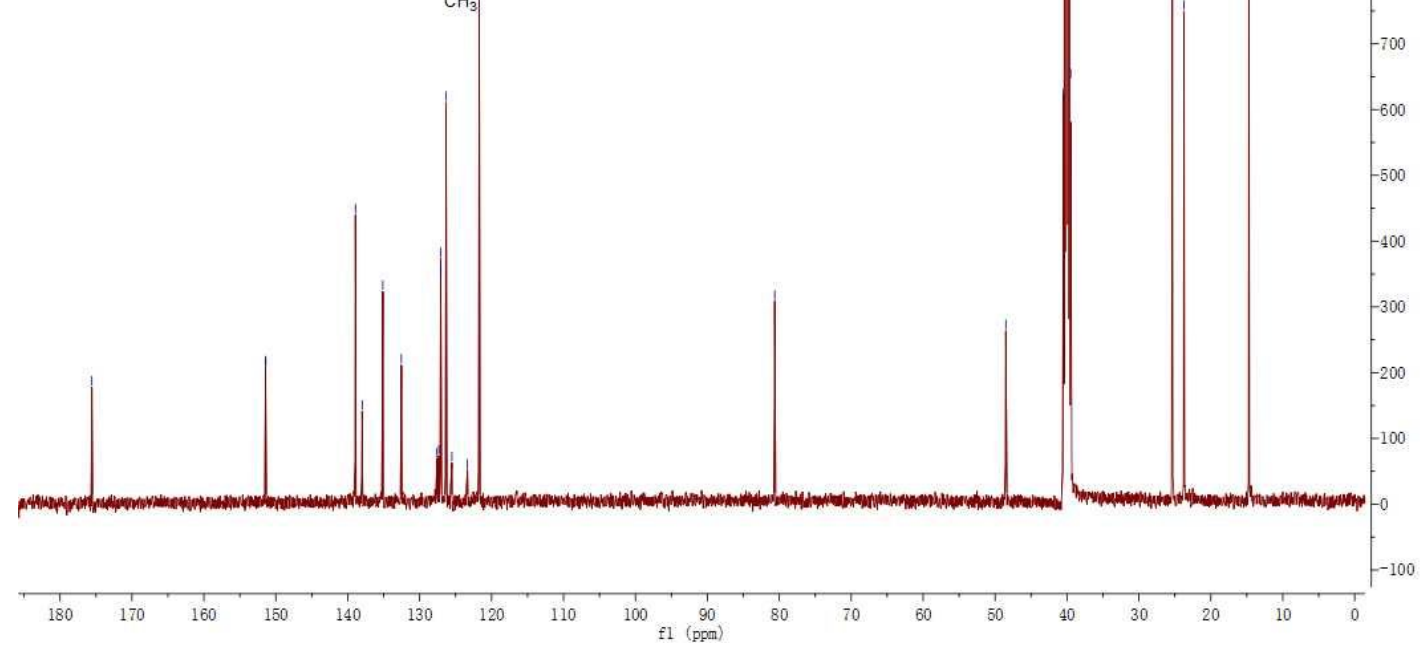


${ }^{1} \mathrm{H}-\mathrm{NMR}$ spectrum (DMSO-d6, $300 \mathrm{MHz}$ ) of H32

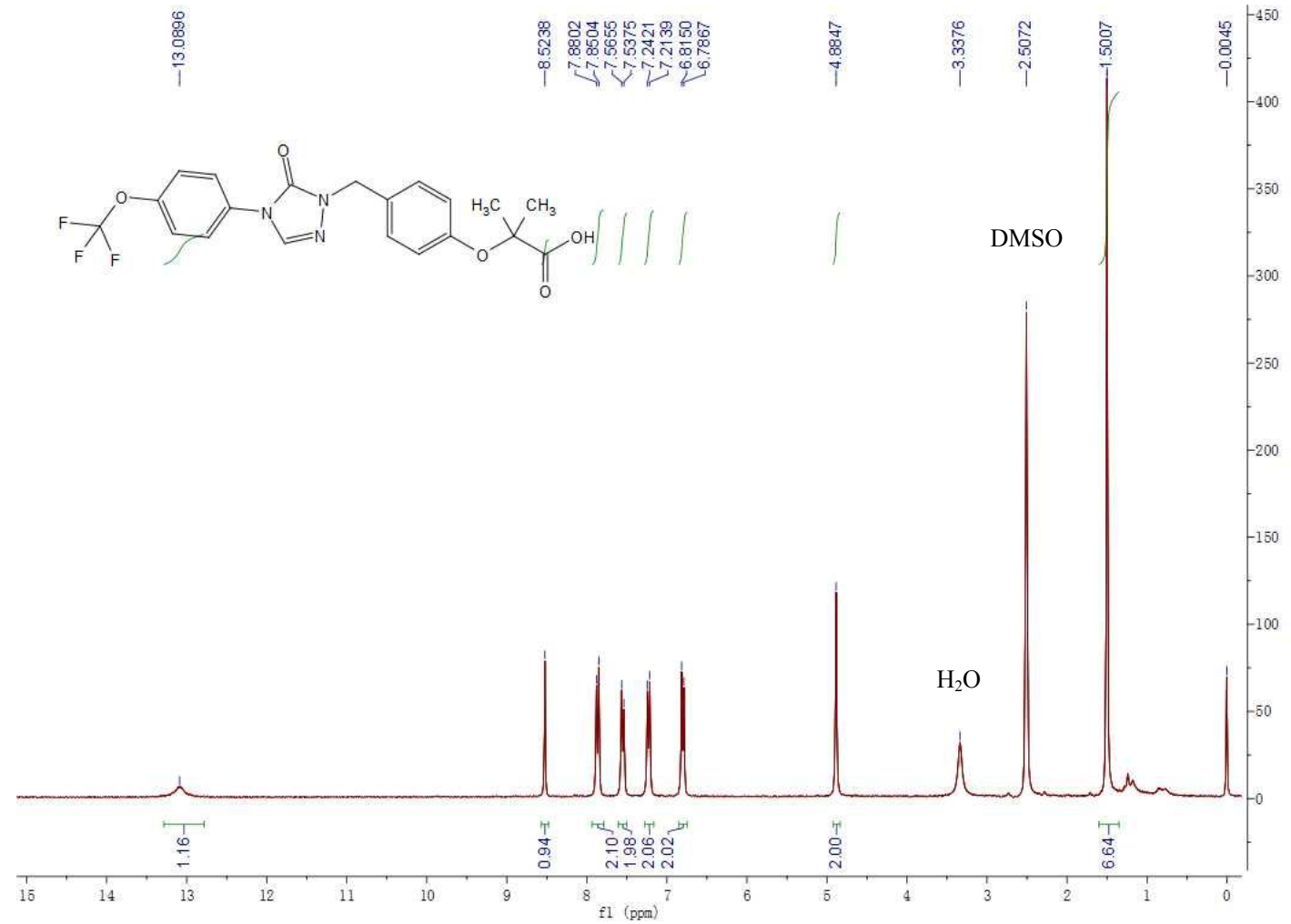

${ }^{13} \mathrm{C}-\mathrm{NMR}$ spectrum (DMSO-d6, $126 \mathrm{MHz}$ ) of $\mathrm{H} 32$
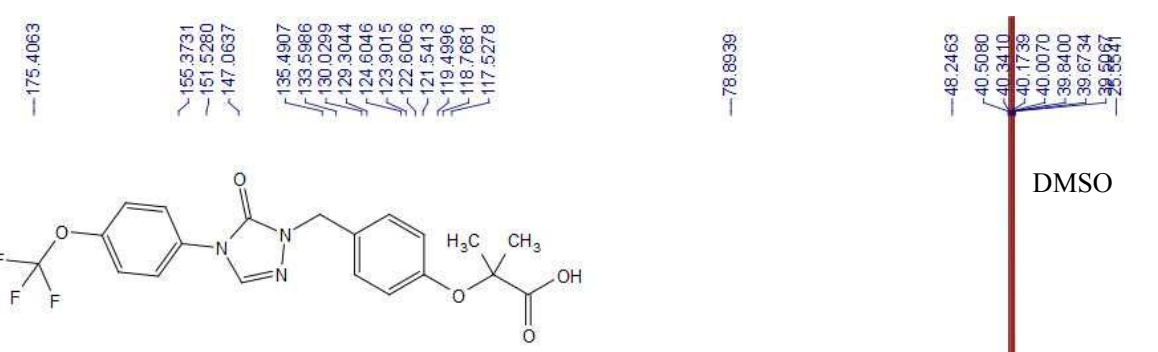

$-3500$ 
${ }^{1} \mathrm{H}-\mathrm{NMR}$ spectrum (DMSO-d6, $300 \mathrm{MHz}$ ) of H33

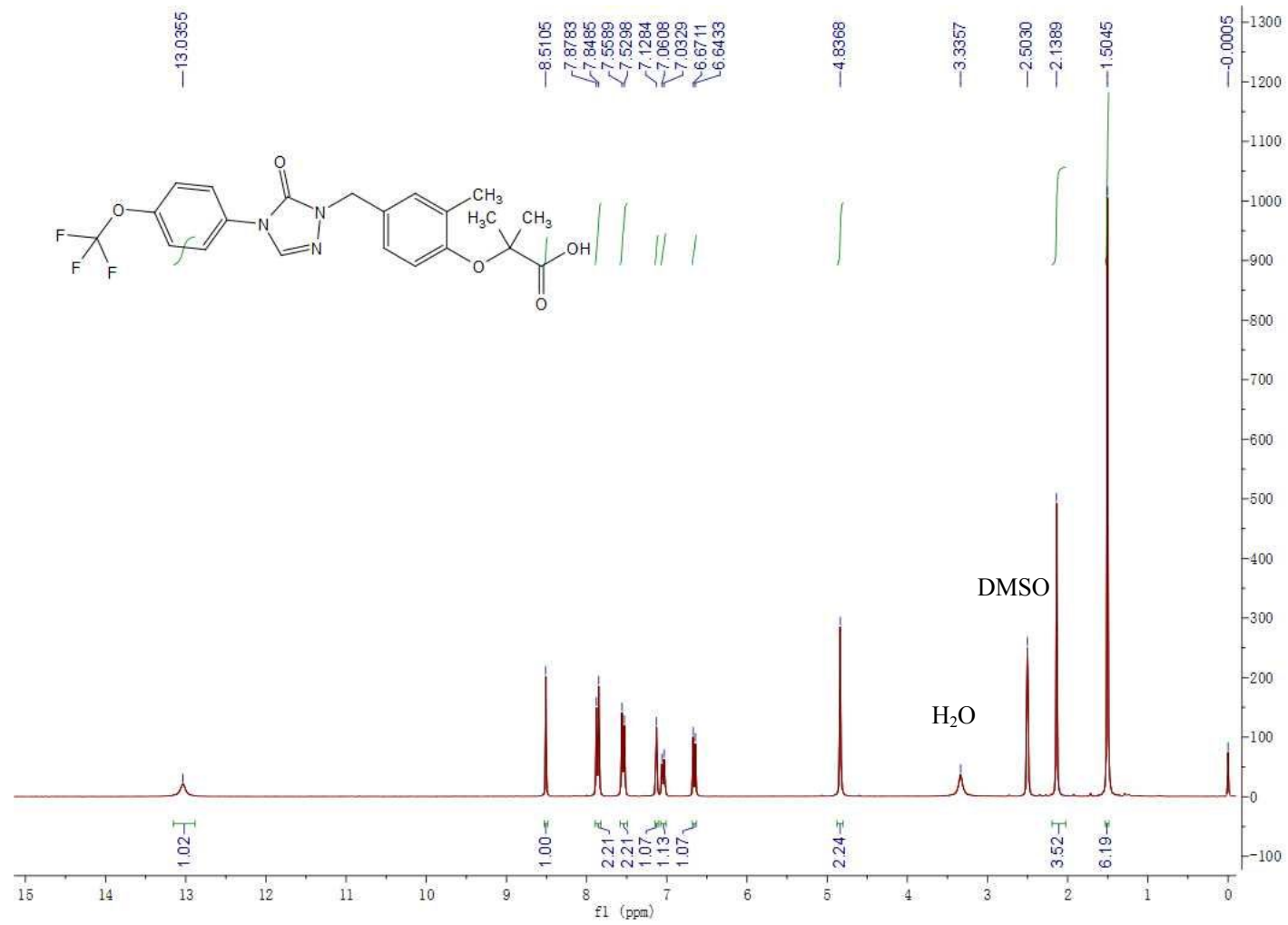

${ }^{13} \mathrm{C}-\mathrm{NMR}$ spectrum (DMSO-d6, $126 \mathrm{MHz}$ ) of $\mathrm{H} 33$

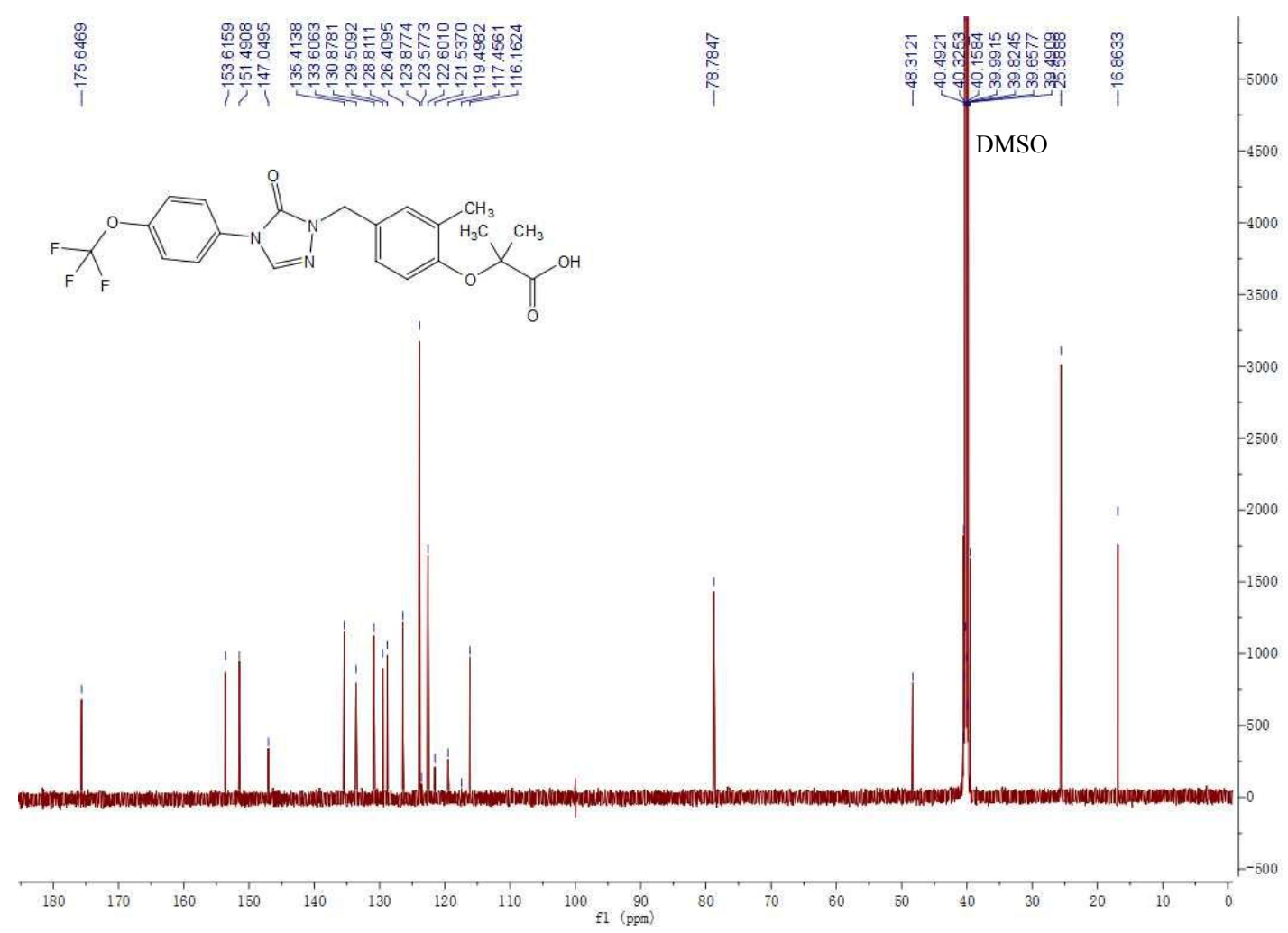




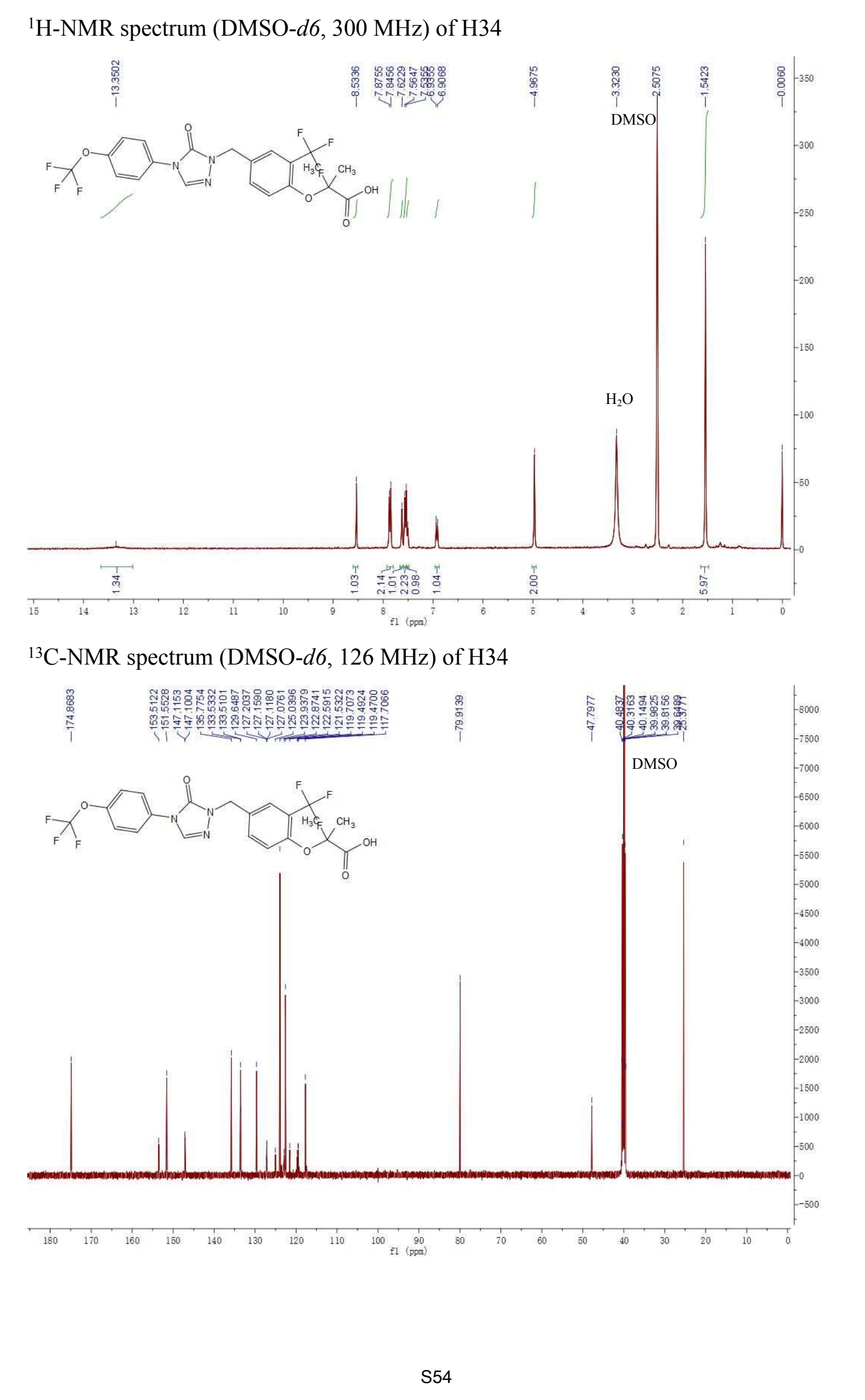


${ }^{1} \mathrm{H}-\mathrm{NMR}$ spectrum (DMSO-d6, $300 \mathrm{MHz}$ ) of H35

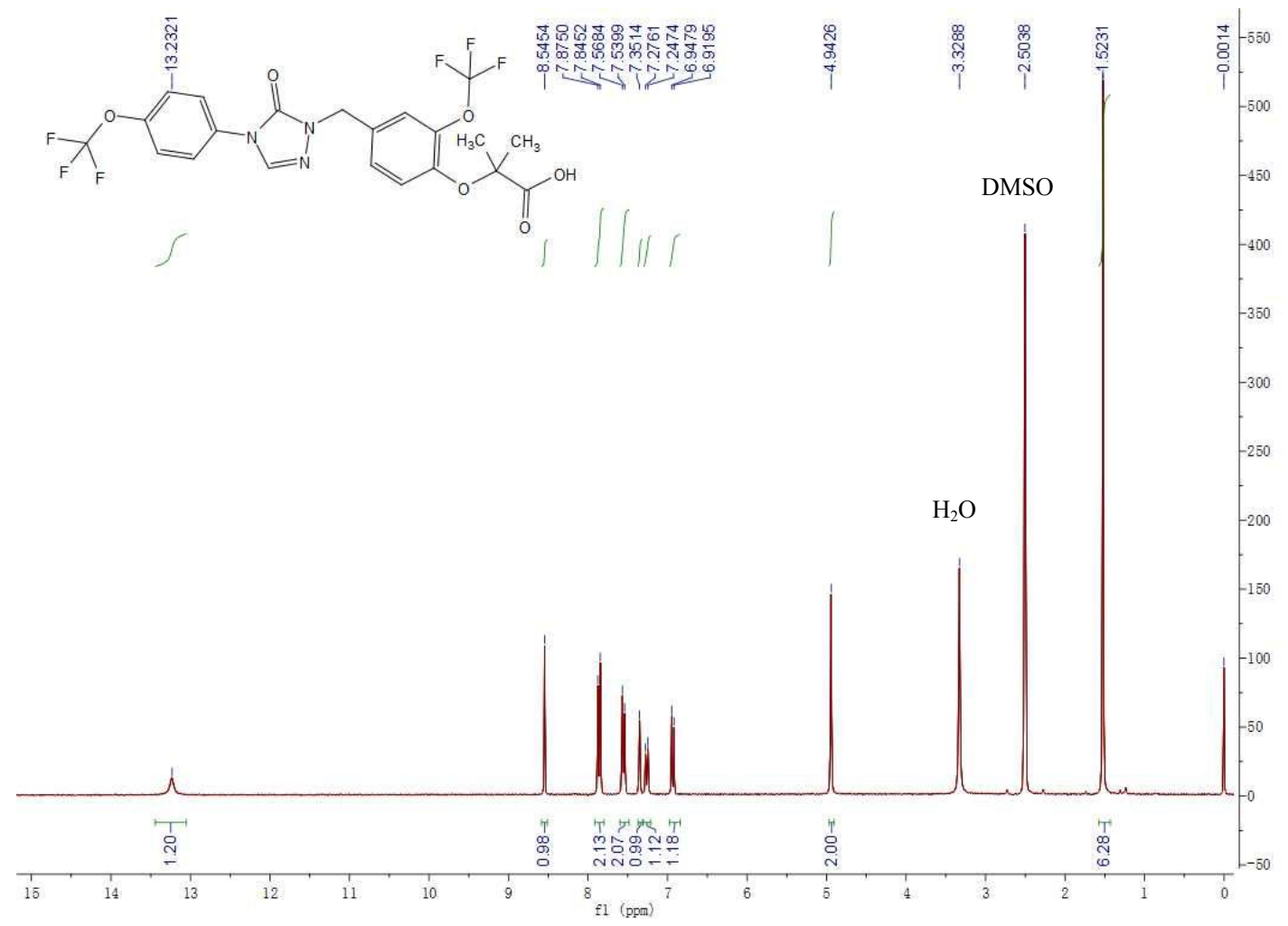

${ }^{13} \mathrm{C}-\mathrm{NMR}$ spectrum (DMSO-d6, $126 \mathrm{MHz}$ ) of $\mathrm{H} 35$

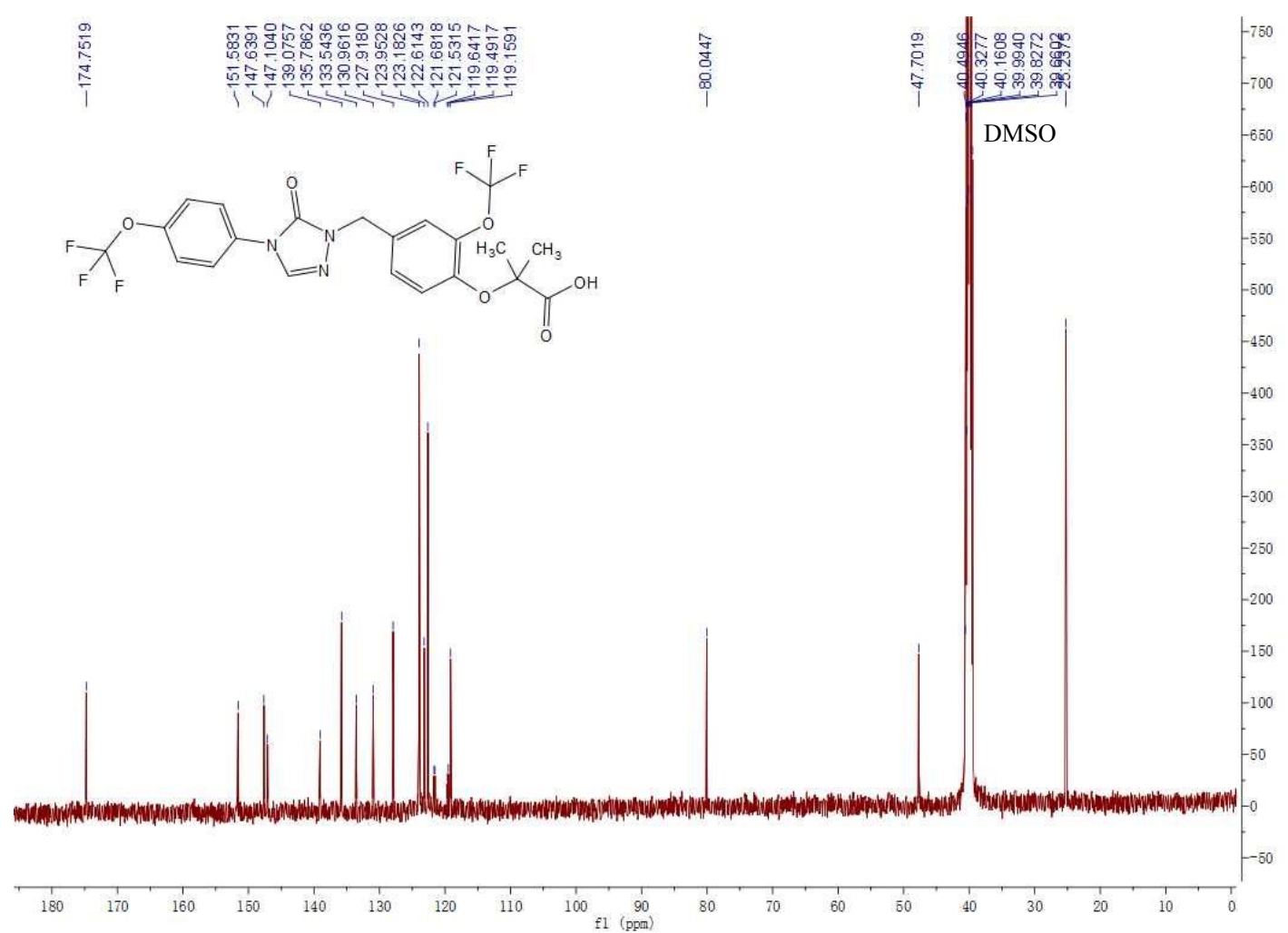


${ }^{1} \mathrm{H}-\mathrm{NMR}$ spectrum (DMSO-d6, $300 \mathrm{MHz}$ ) of H36

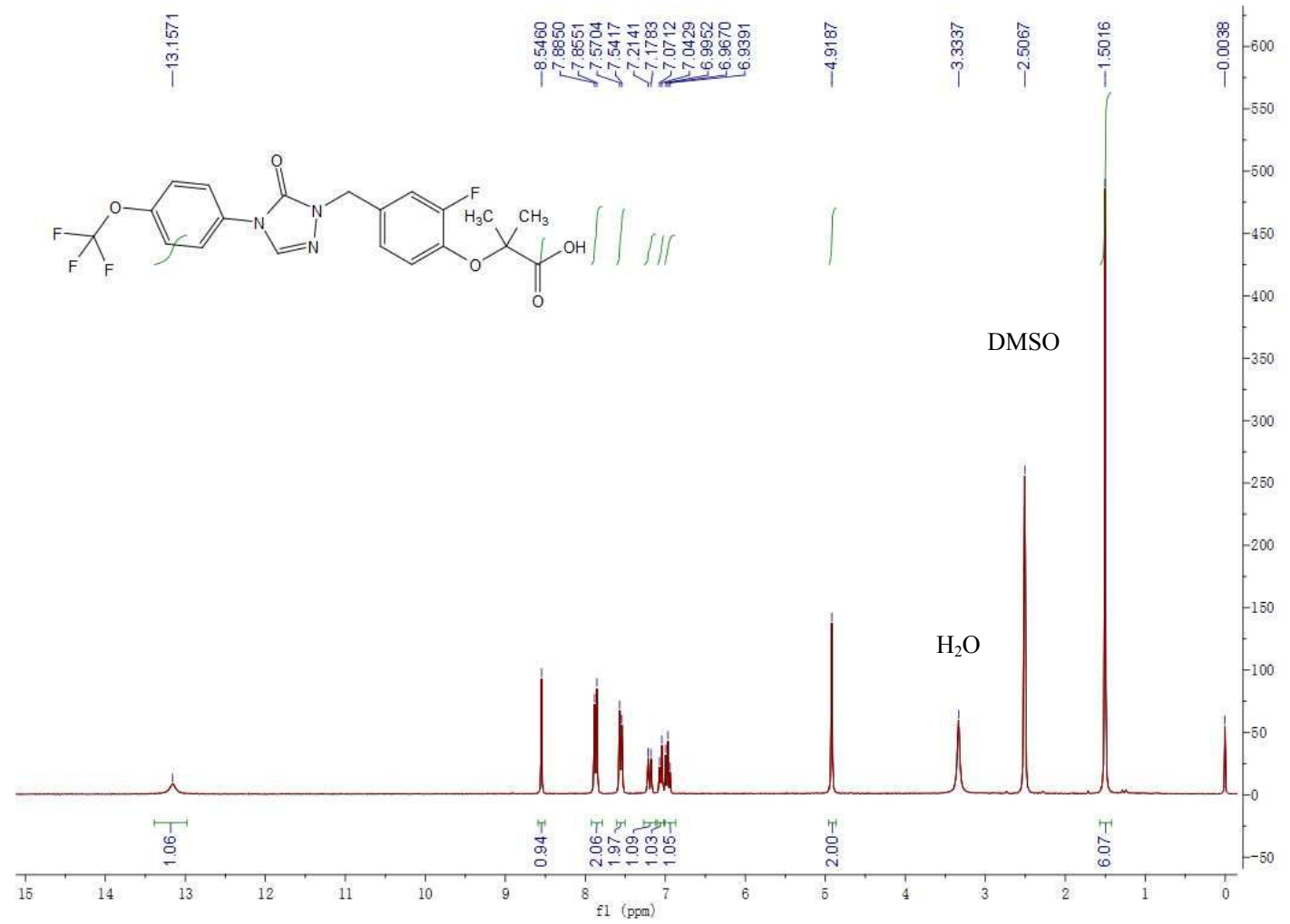

${ }^{13} \mathrm{C}-\mathrm{NMR}$ spectrum (DMSO-d6, $126 \mathrm{MHz}$ ) of H36

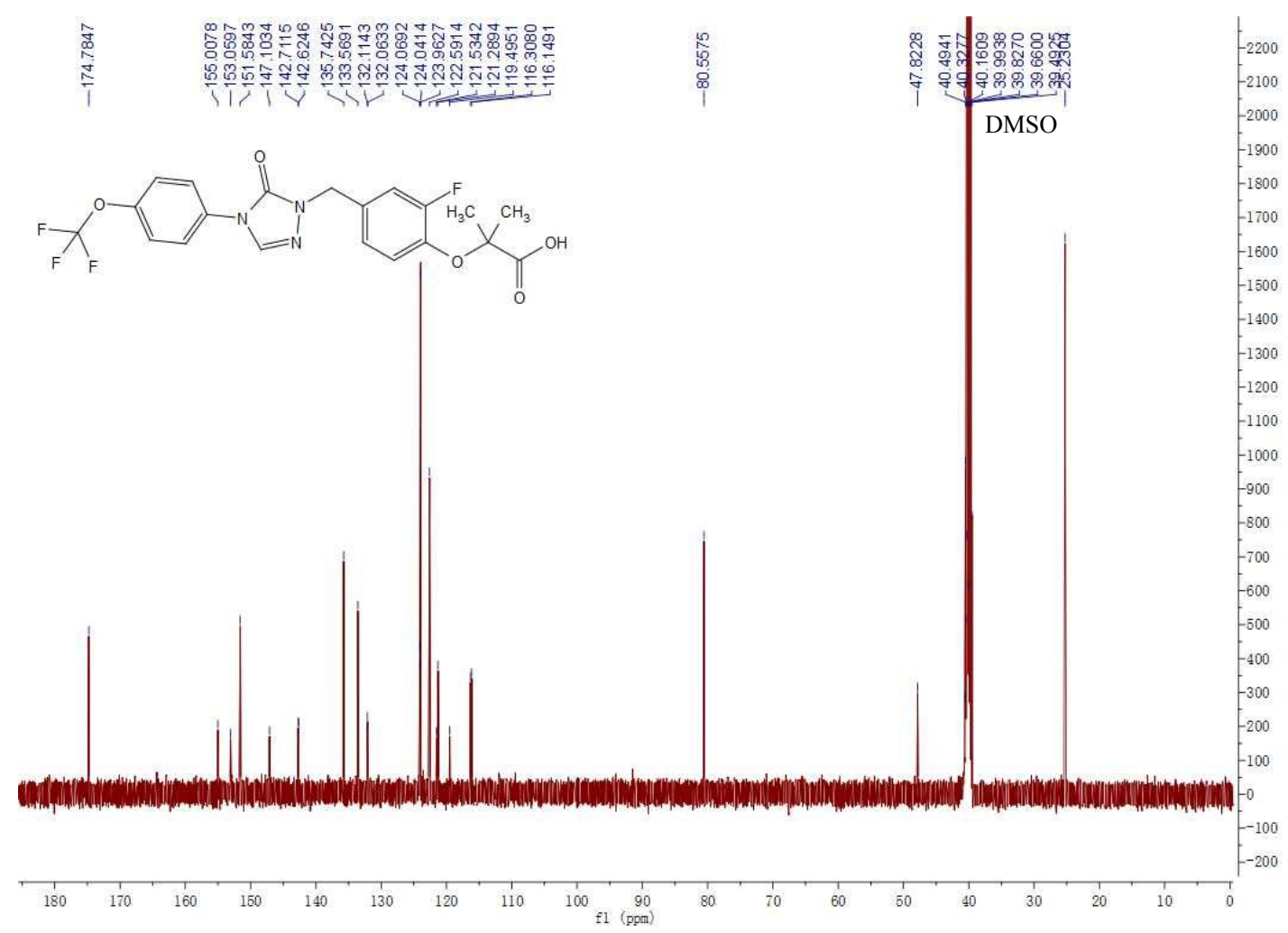


${ }^{1} \mathrm{H}-\mathrm{NMR}$ spectrum (DMSO-d6, $300 \mathrm{MHz}$ ) of H37

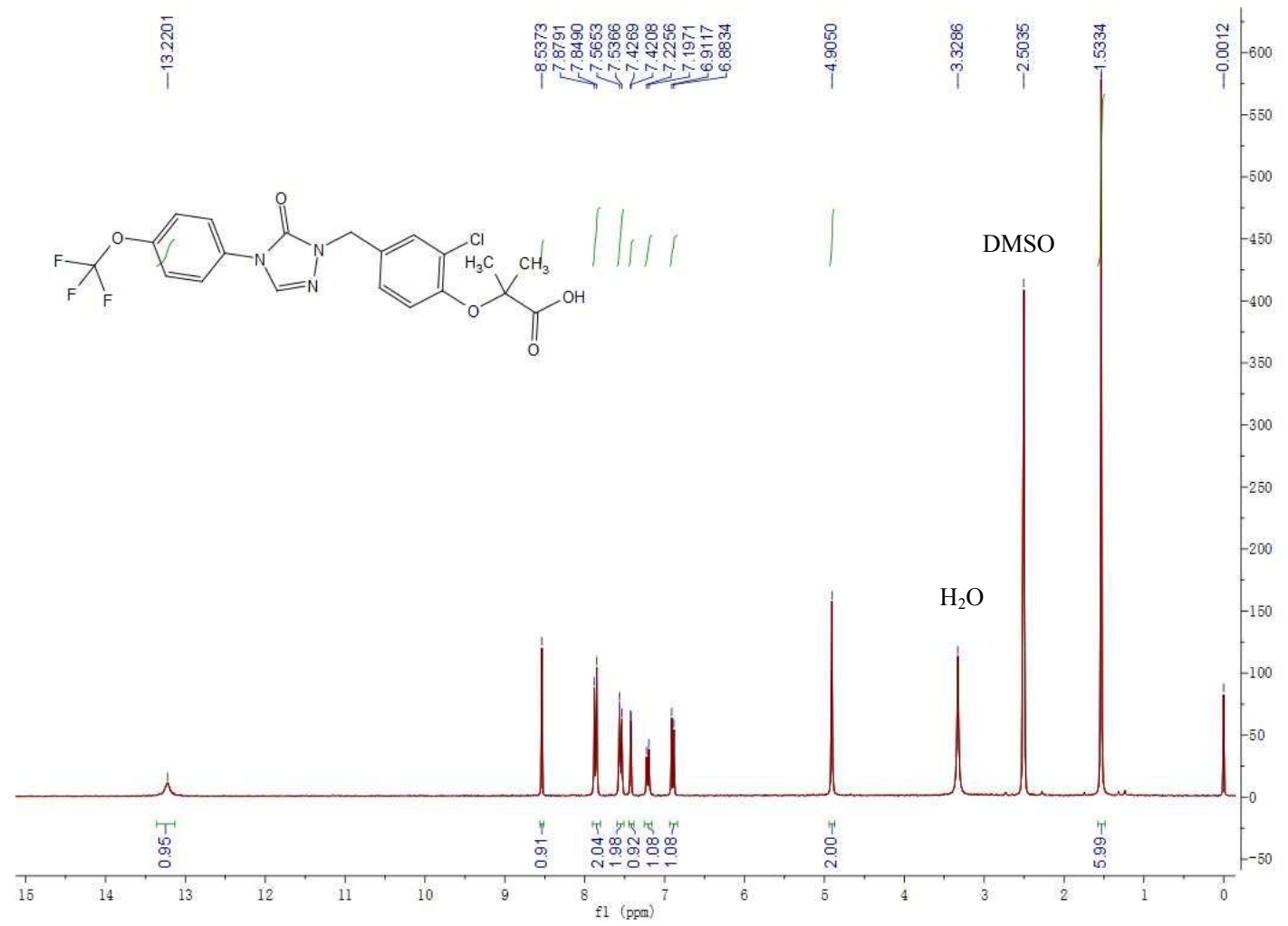

${ }^{13} \mathrm{C}-\mathrm{NMR}$ spectrum (DMSO-d6, $126 \mathrm{MHz}$ ) of $\mathrm{H} 37$

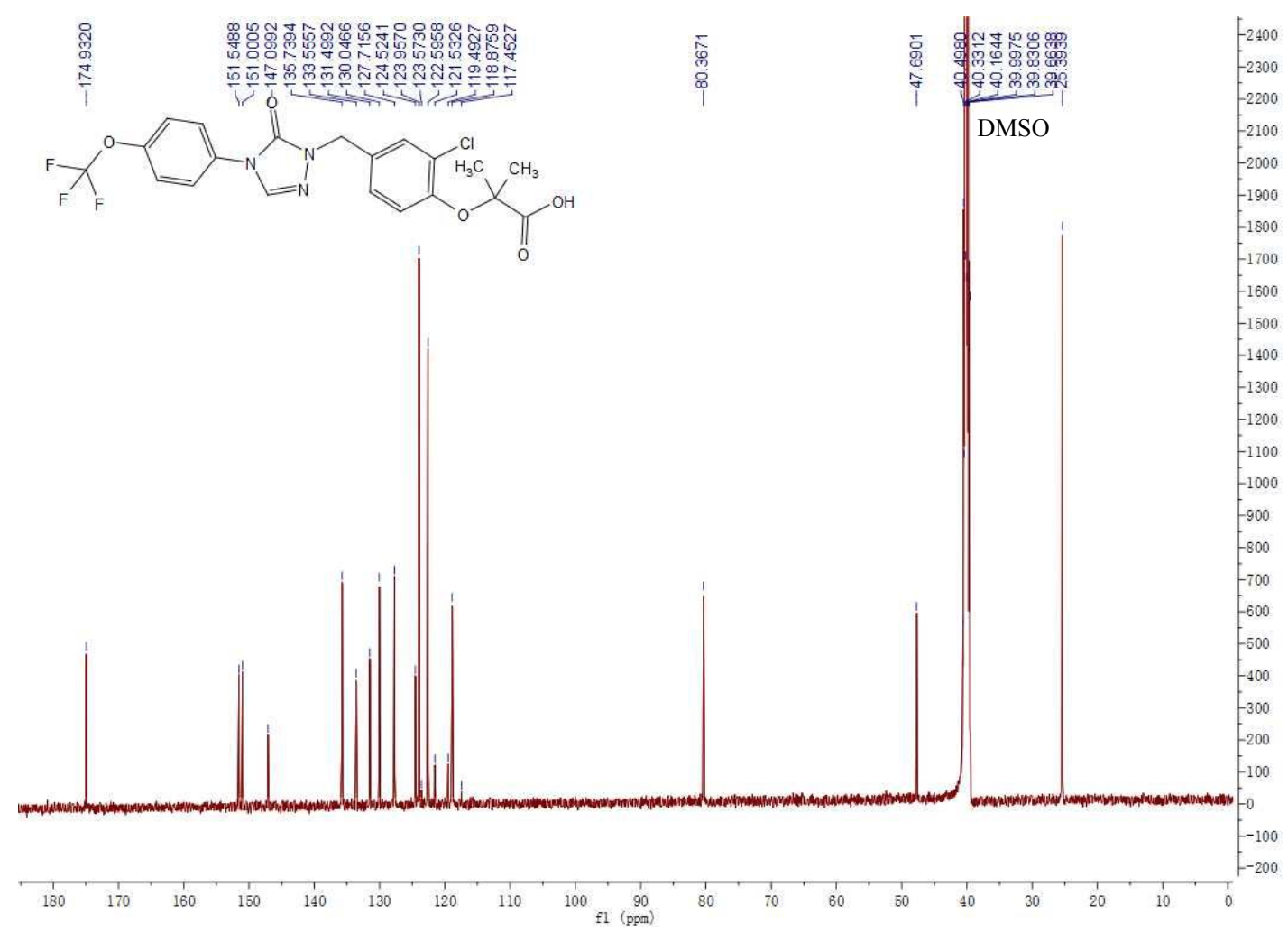


${ }^{1} \mathrm{H}-\mathrm{NMR}$ spectrum (DMSO-d6, $300 \mathrm{MHz}$ ) of H38

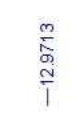

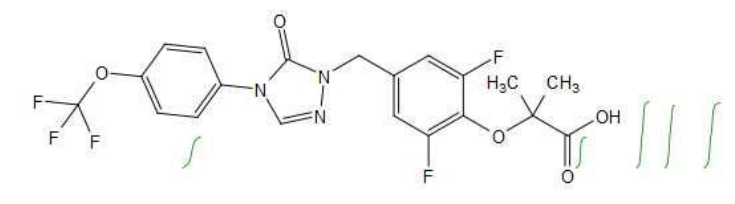

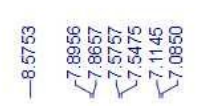

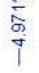

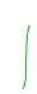



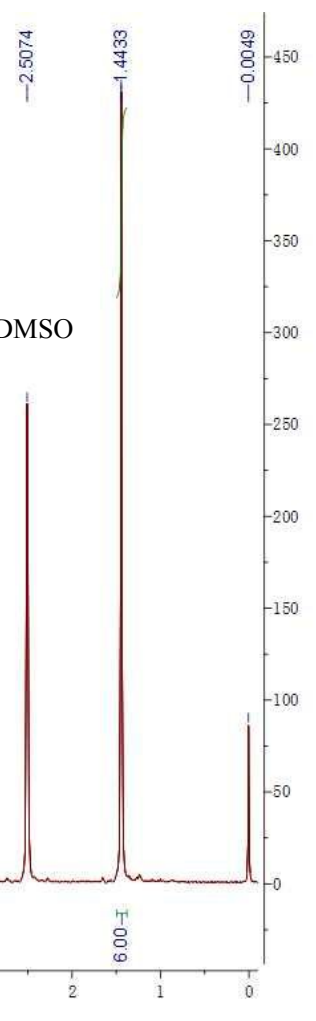

${ }^{13} \mathrm{C}-\mathrm{NMR}$ spectrum (DMSO-d6, $126 \mathrm{MHz}$ ) of $\mathrm{H} 38$
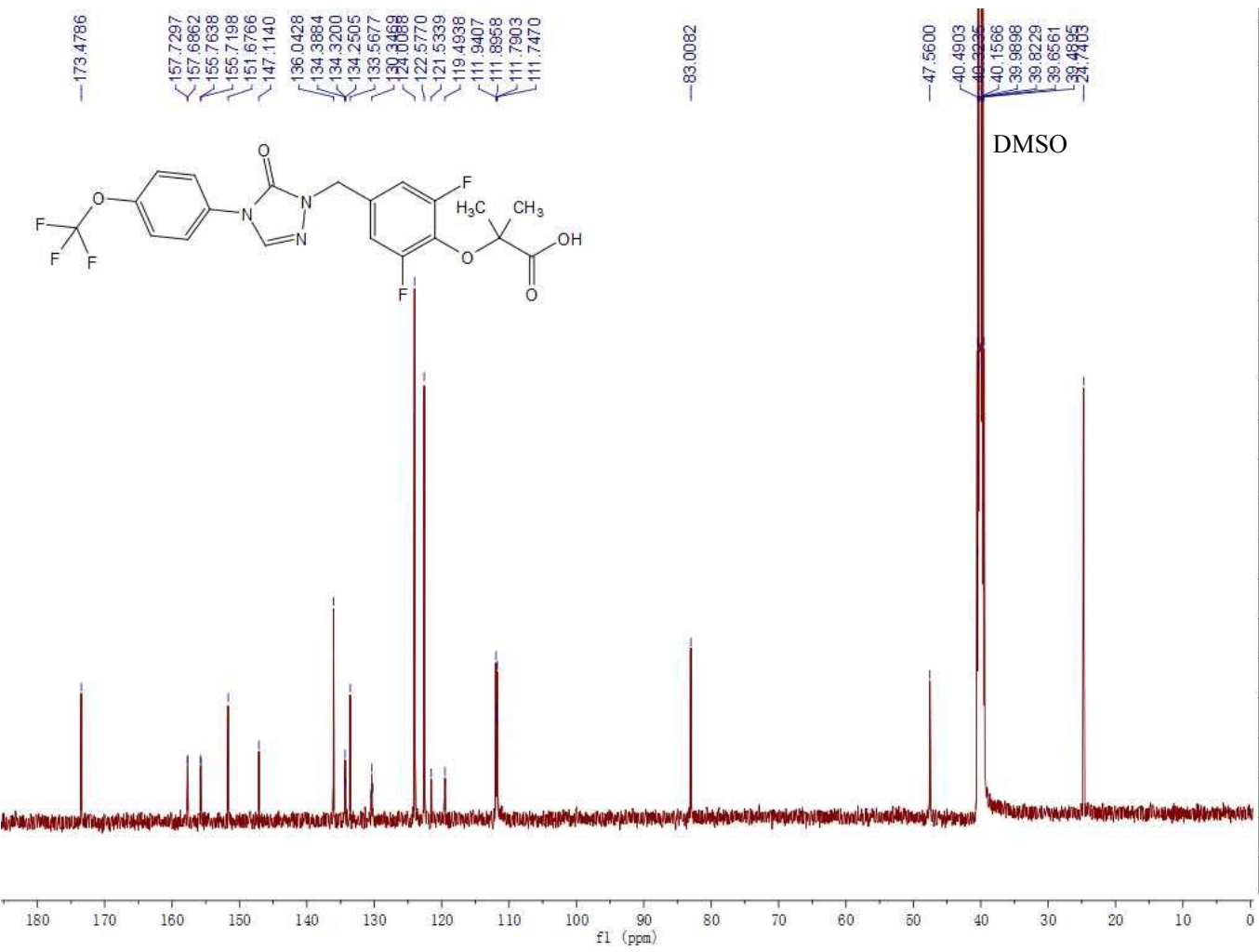
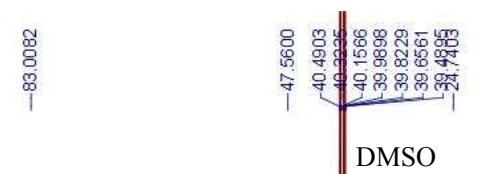

DMSO

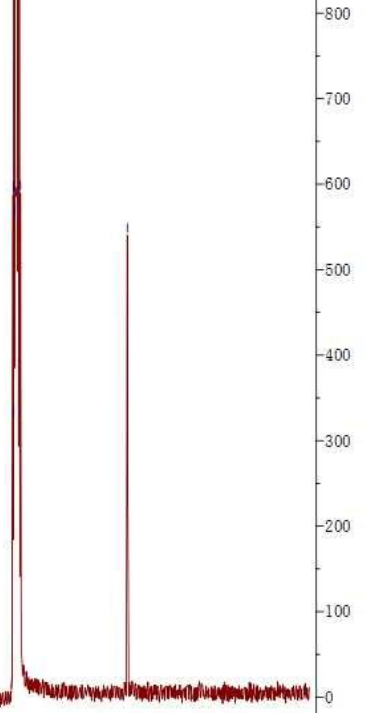

S58 
${ }^{1} \mathrm{H}-\mathrm{NMR}$ spectrum (DMSO-d6, $300 \mathrm{MHz}$ ) of H39
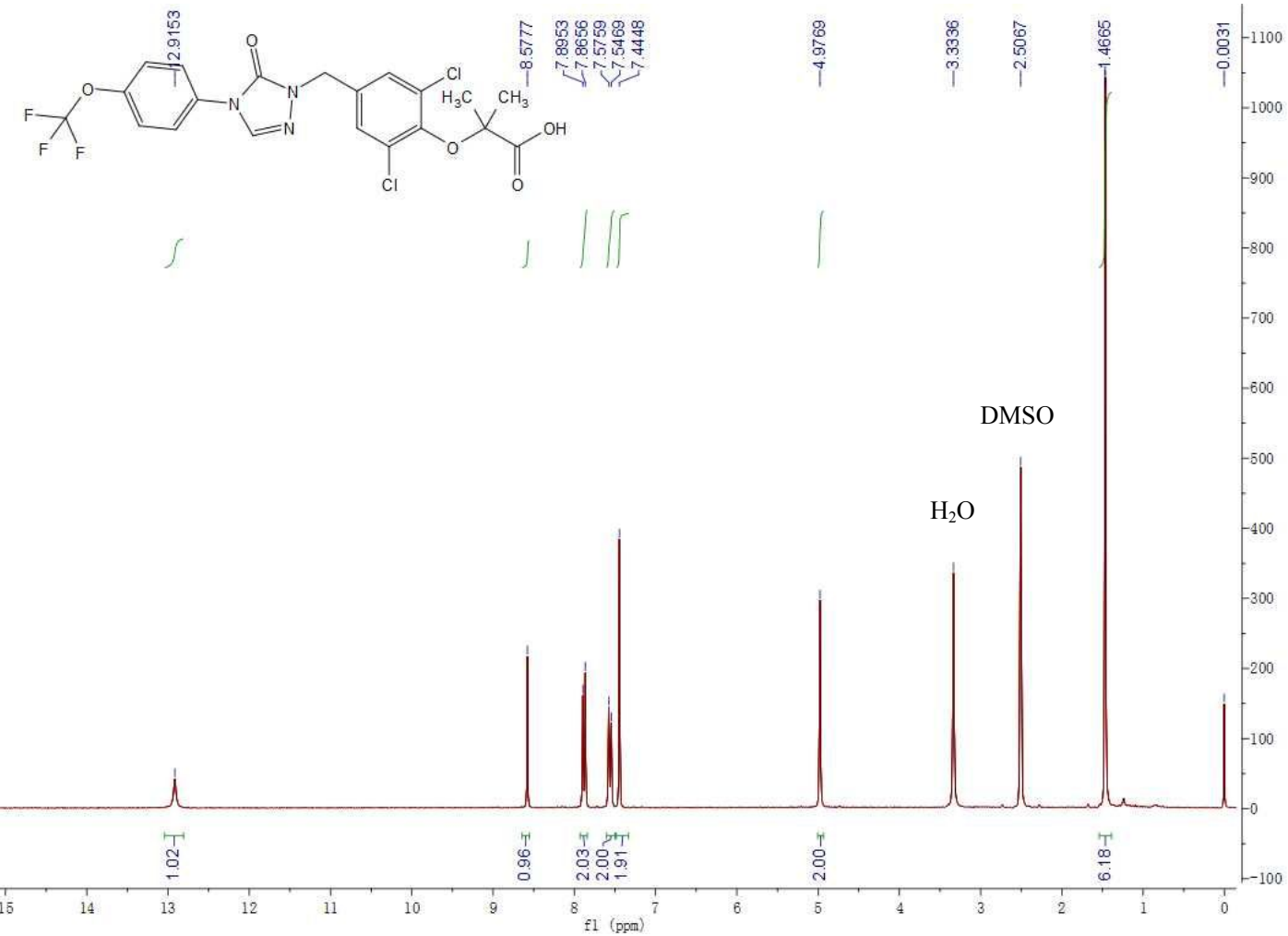

${ }^{13} \mathrm{C}-\mathrm{NMR}$ spectrum (DMSO-d6, $126 \mathrm{MHz}$ ) of $\mathrm{H} 39$

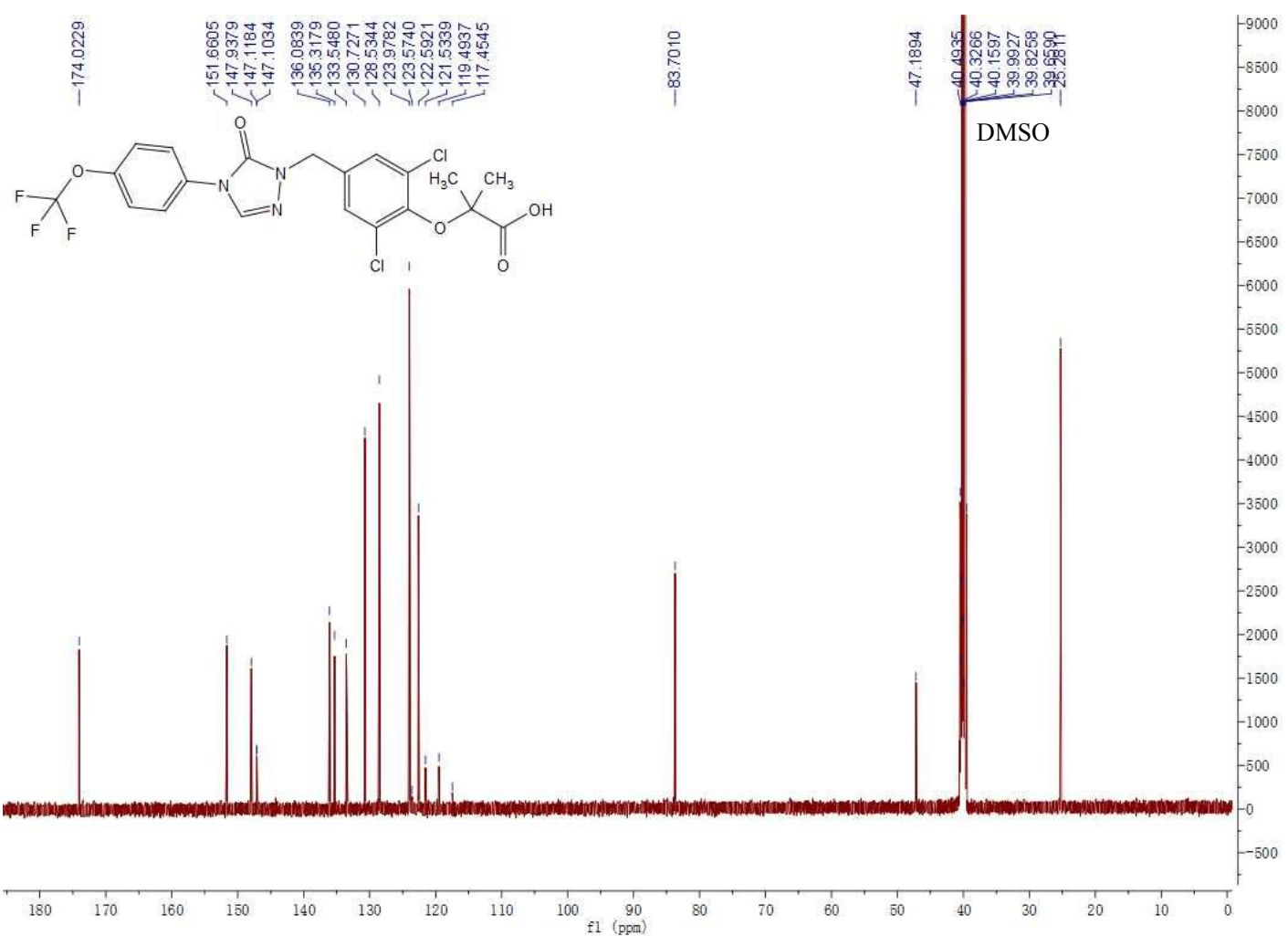


${ }^{1} \mathrm{H}-\mathrm{NMR}$ spectrum (DMSO-d6, $300 \mathrm{MHz}$ ) of $\mathrm{H} 40$

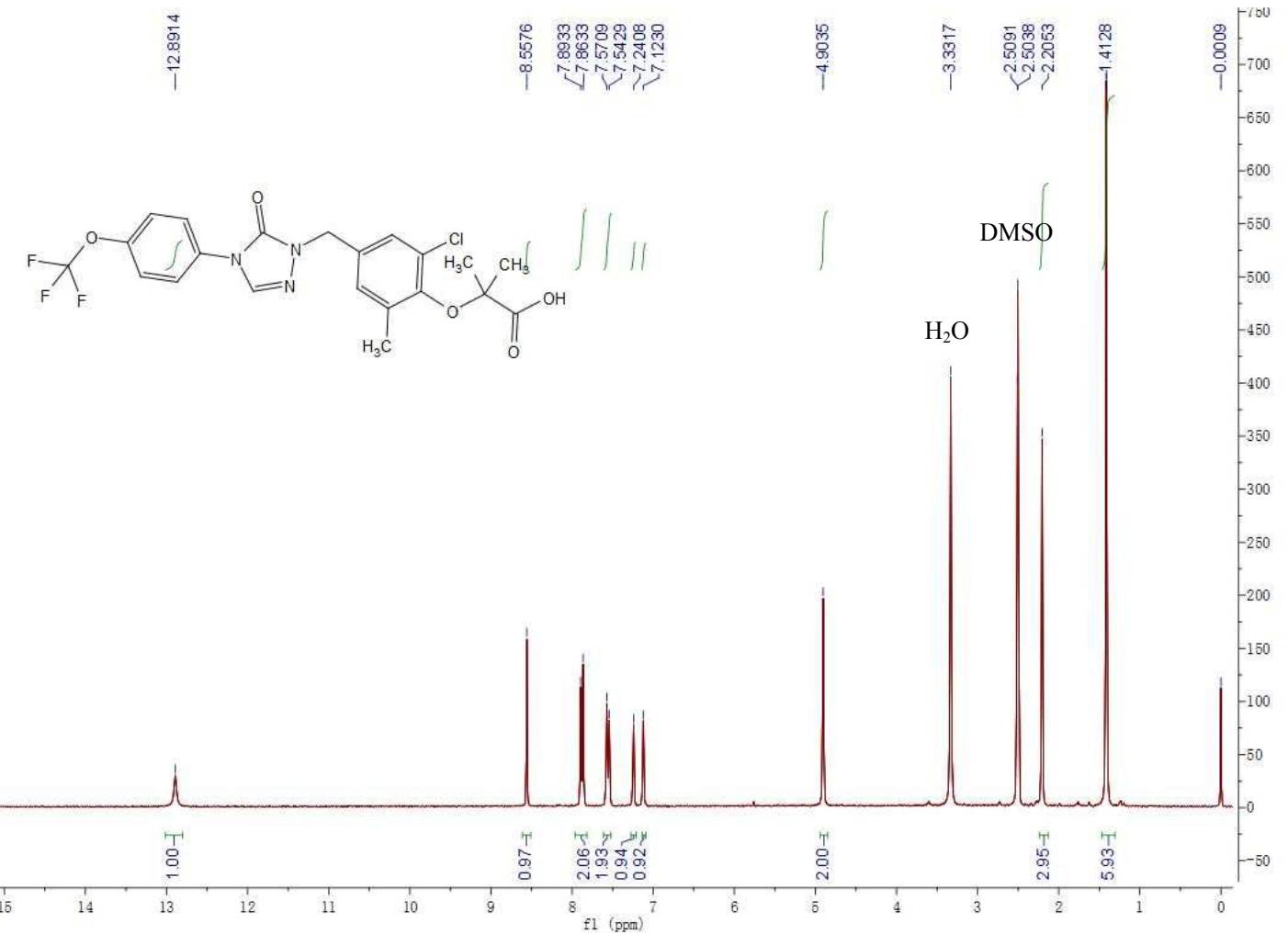

${ }^{13} \mathrm{C}-\mathrm{NMR}$ spectrum (DMSO- $d 6,126 \mathrm{MHz}$ ) of $\mathrm{H} 40$

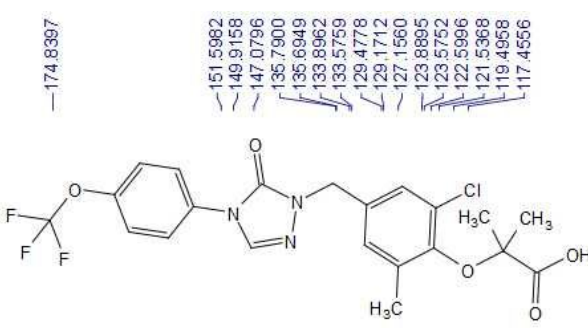

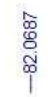
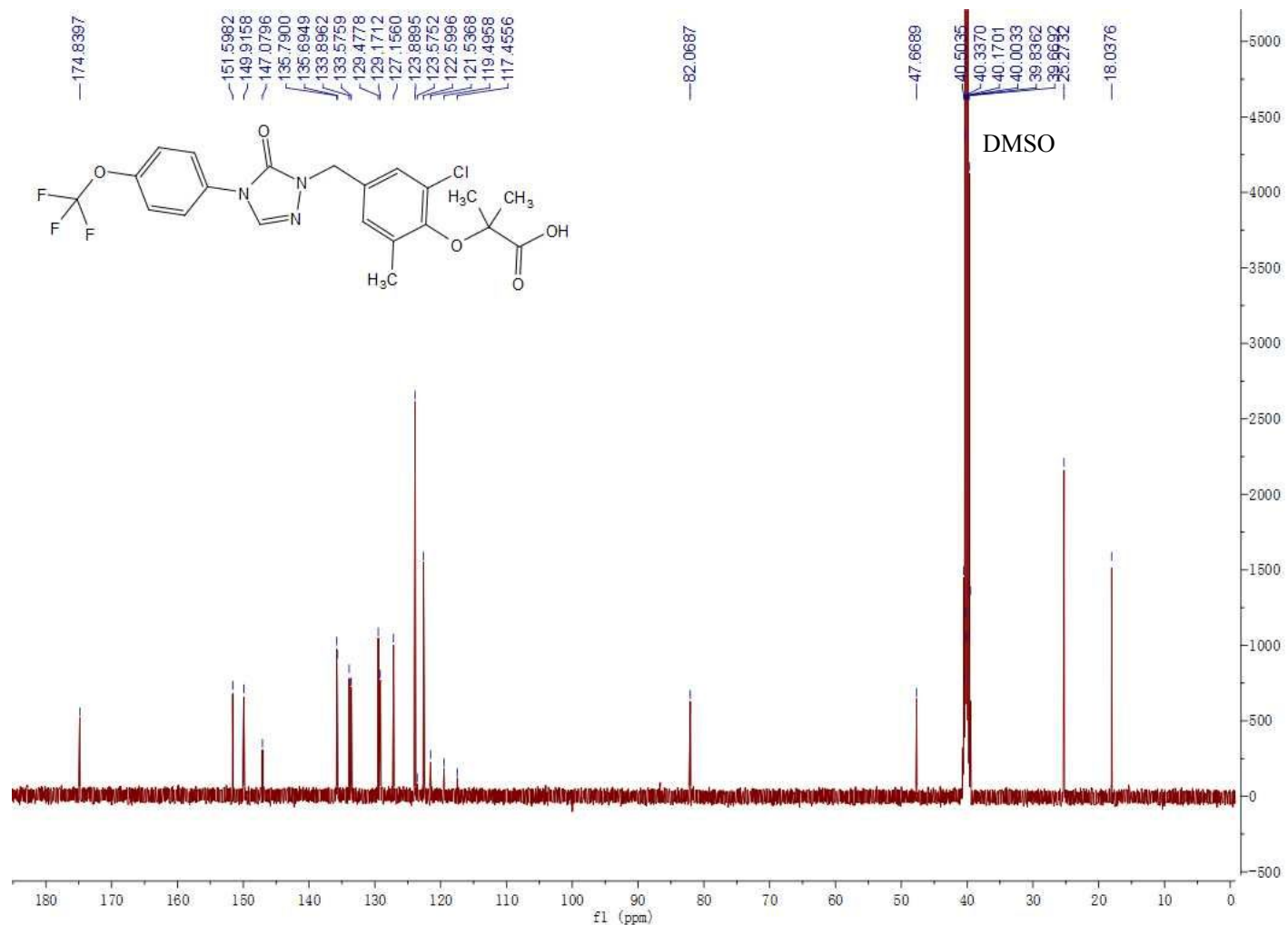
${ }^{1} \mathrm{H}-\mathrm{NMR}$ spectrum (DMSO-d6, $300 \mathrm{MHz}$ ) of $\mathrm{H} 41$

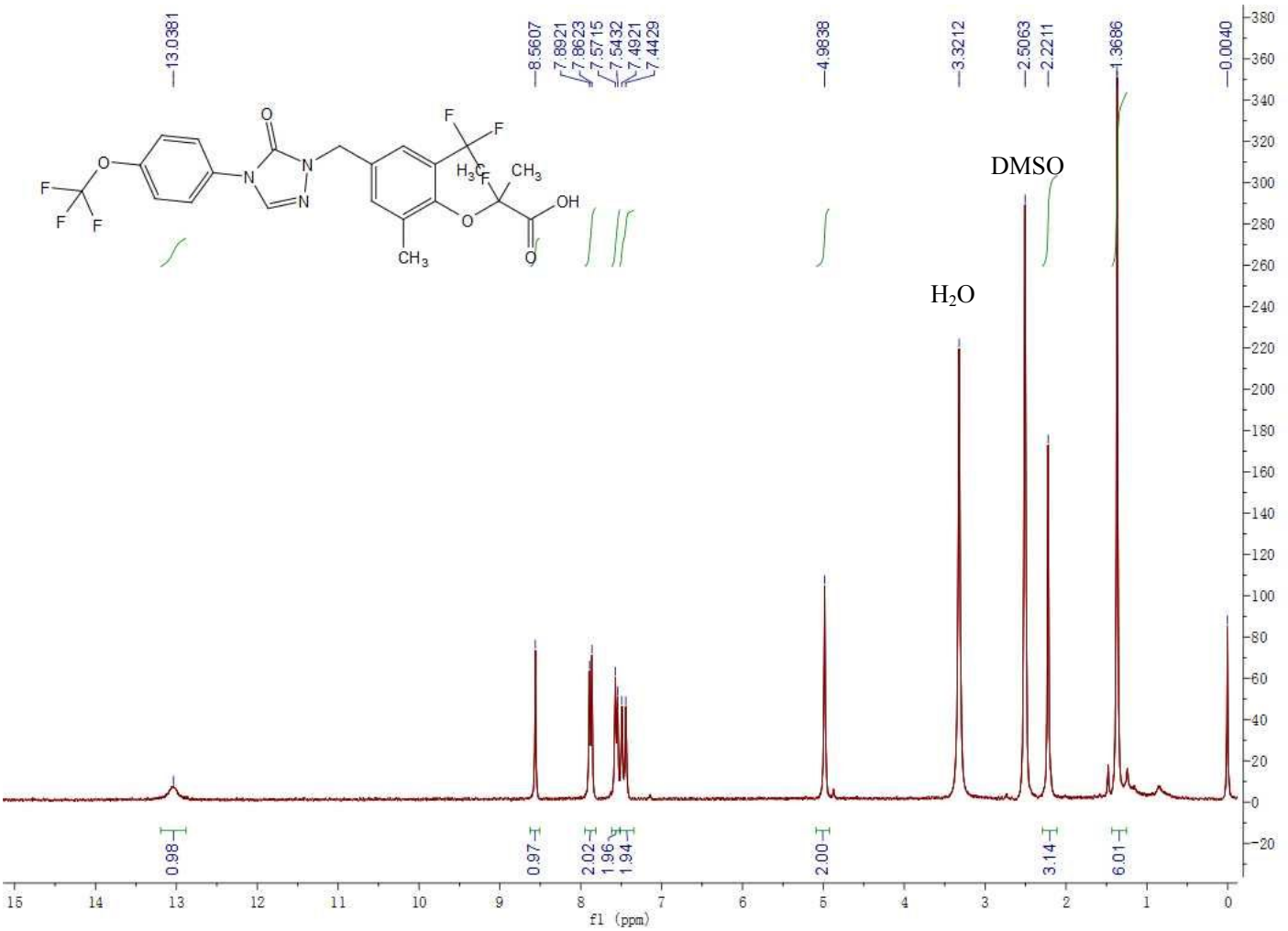

${ }^{13} \mathrm{C}-\mathrm{NMR}$ spectrum (DMSO-d6, $126 \mathrm{MHz}$ ) of $\mathrm{H} 41$

0
0.0
0.0
0

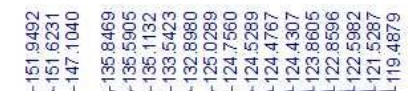

든ㅎㅇ

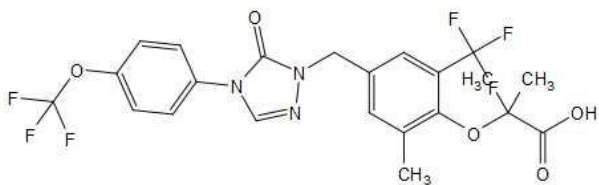

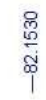

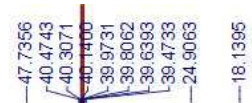

3000

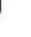


${ }^{1} \mathrm{H}-\mathrm{NMR}$ spectrum (DMSO-d6, $300 \mathrm{MHz}$ ) of $\mathrm{H} 42$

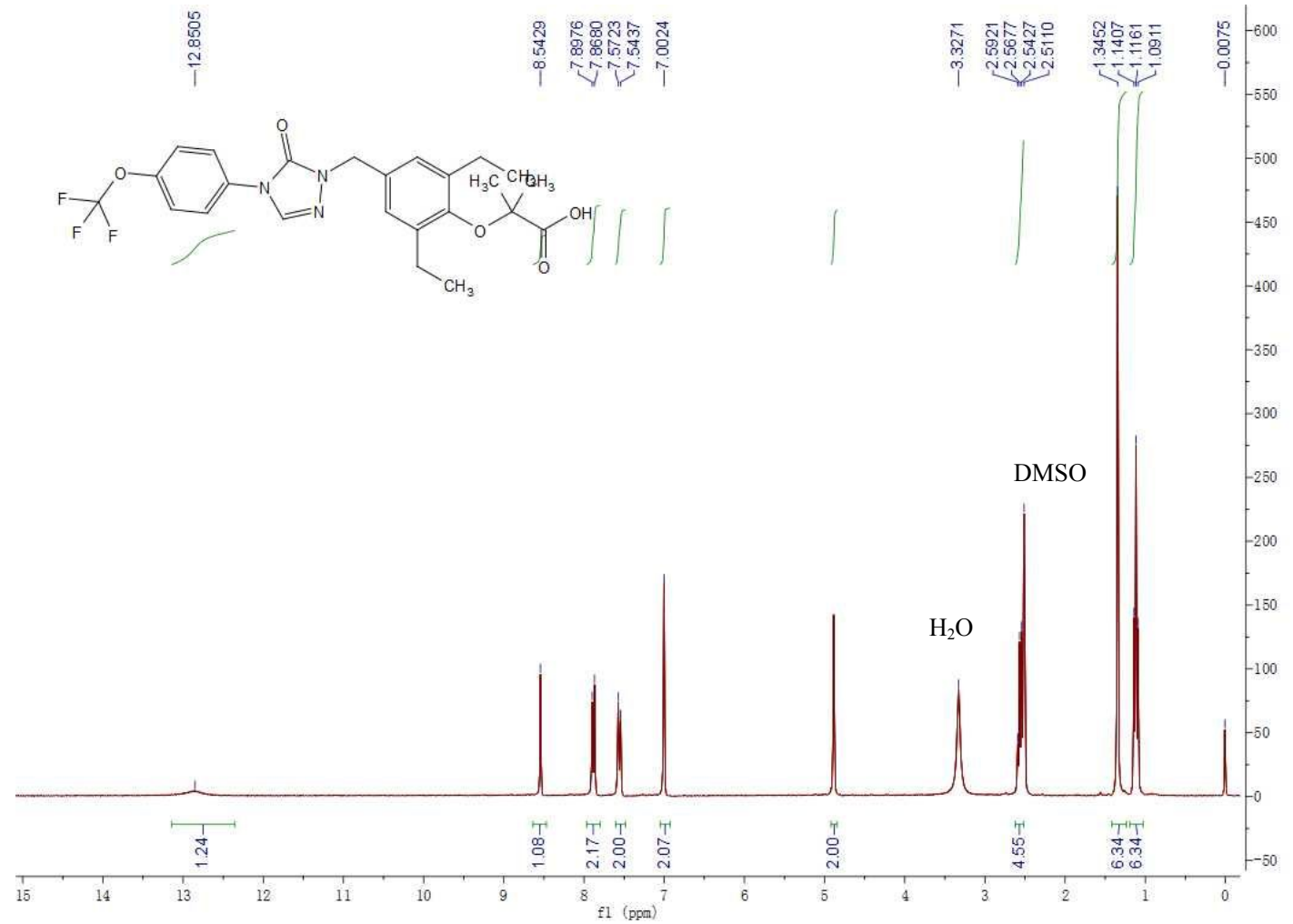

${ }^{13} \mathrm{C}-\mathrm{NMR}$ spectrum (DMSO-d6, $126 \mathrm{MHz}$ ) of $\mathrm{H} 42$
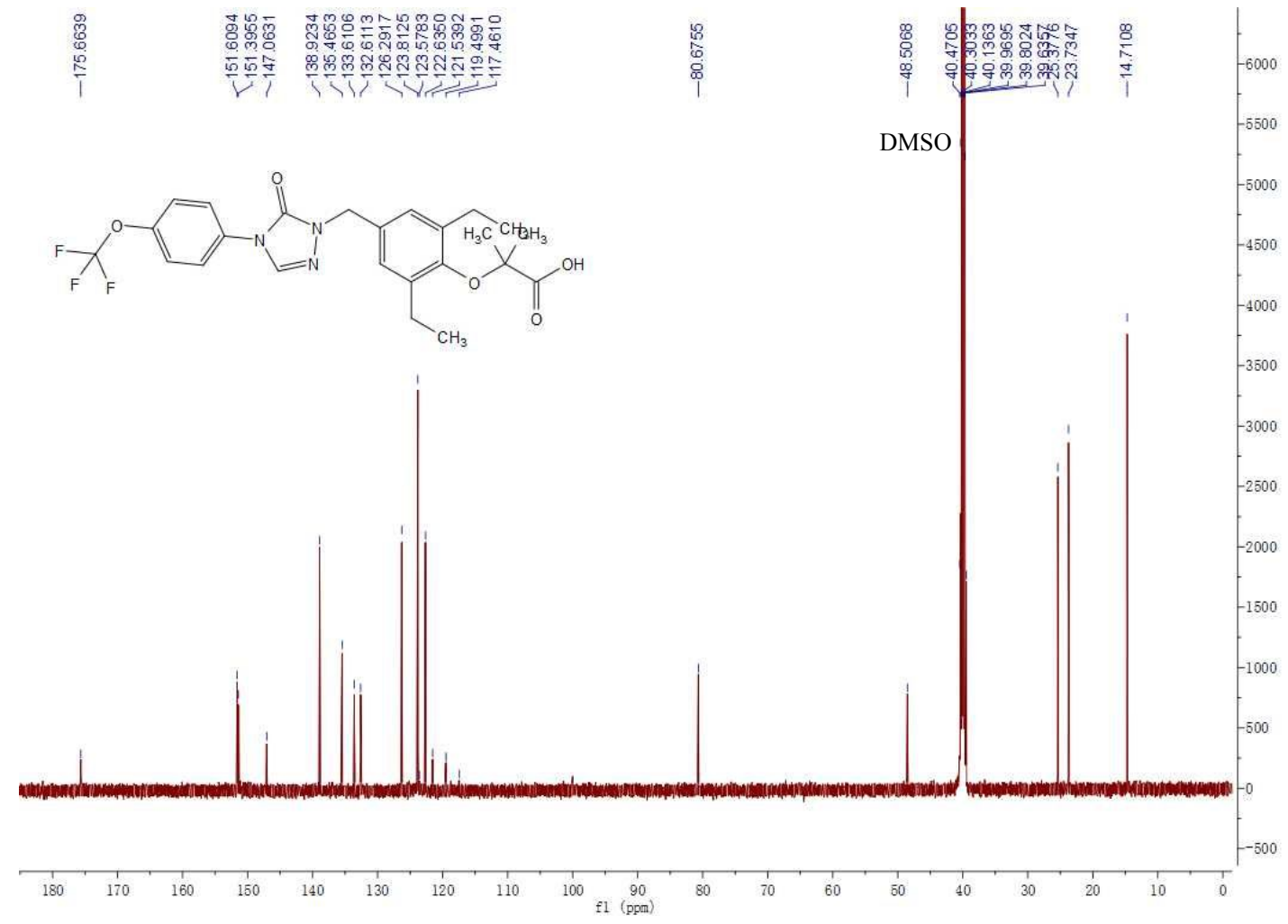
${ }^{1}$ H NMR spectra of GFT-505, IVA-337 and compound 8.

${ }^{1} \mathrm{H}-\mathrm{NMR}$ spectrum (DMSO-d6, $300 \mathrm{MHz}$ ) of GFT-505

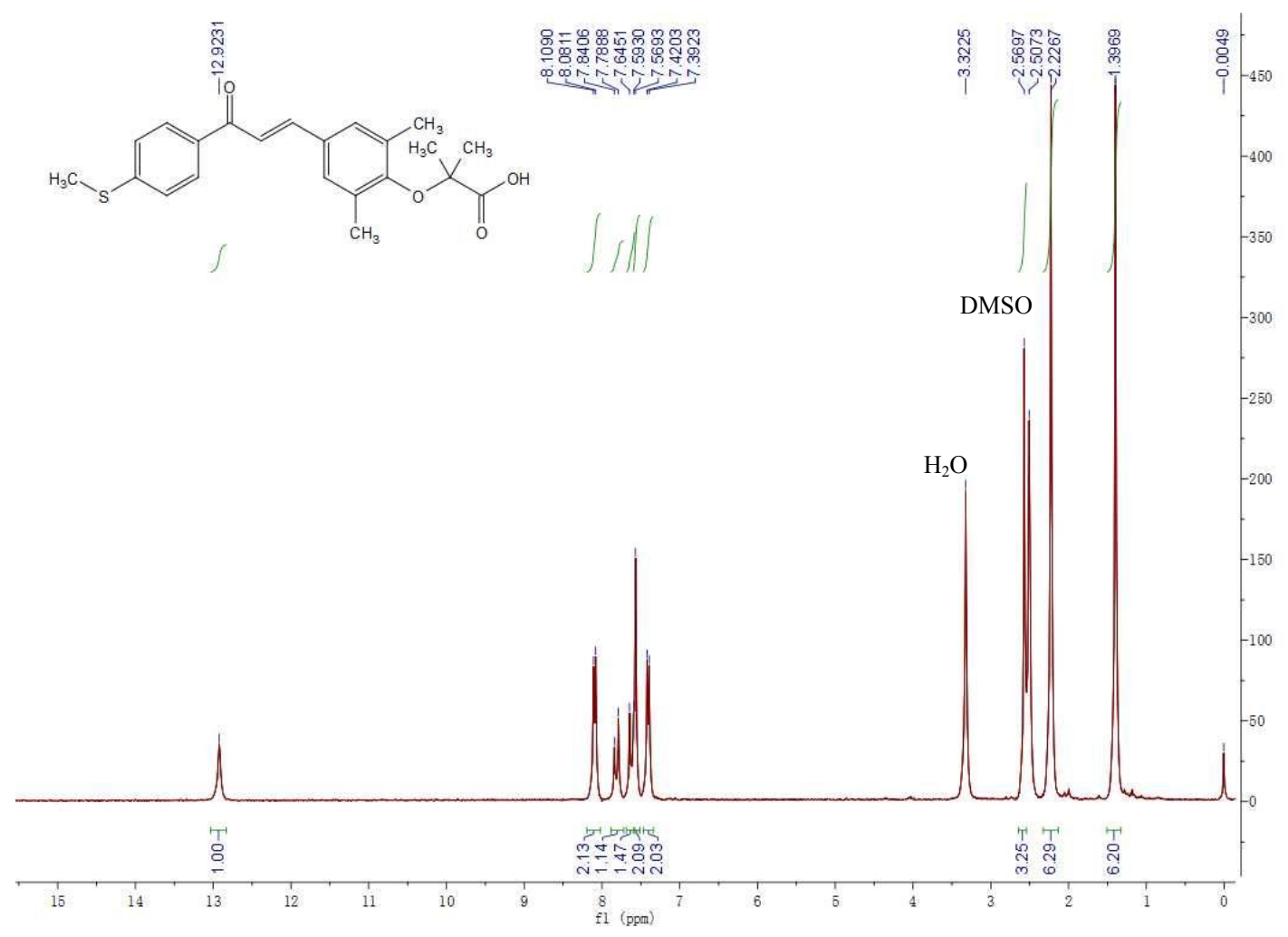

${ }^{1} \mathrm{H}-\mathrm{NMR}$ spectrum (DMSO-d6, $300 \mathrm{MHz}$ ) of IVA-3337

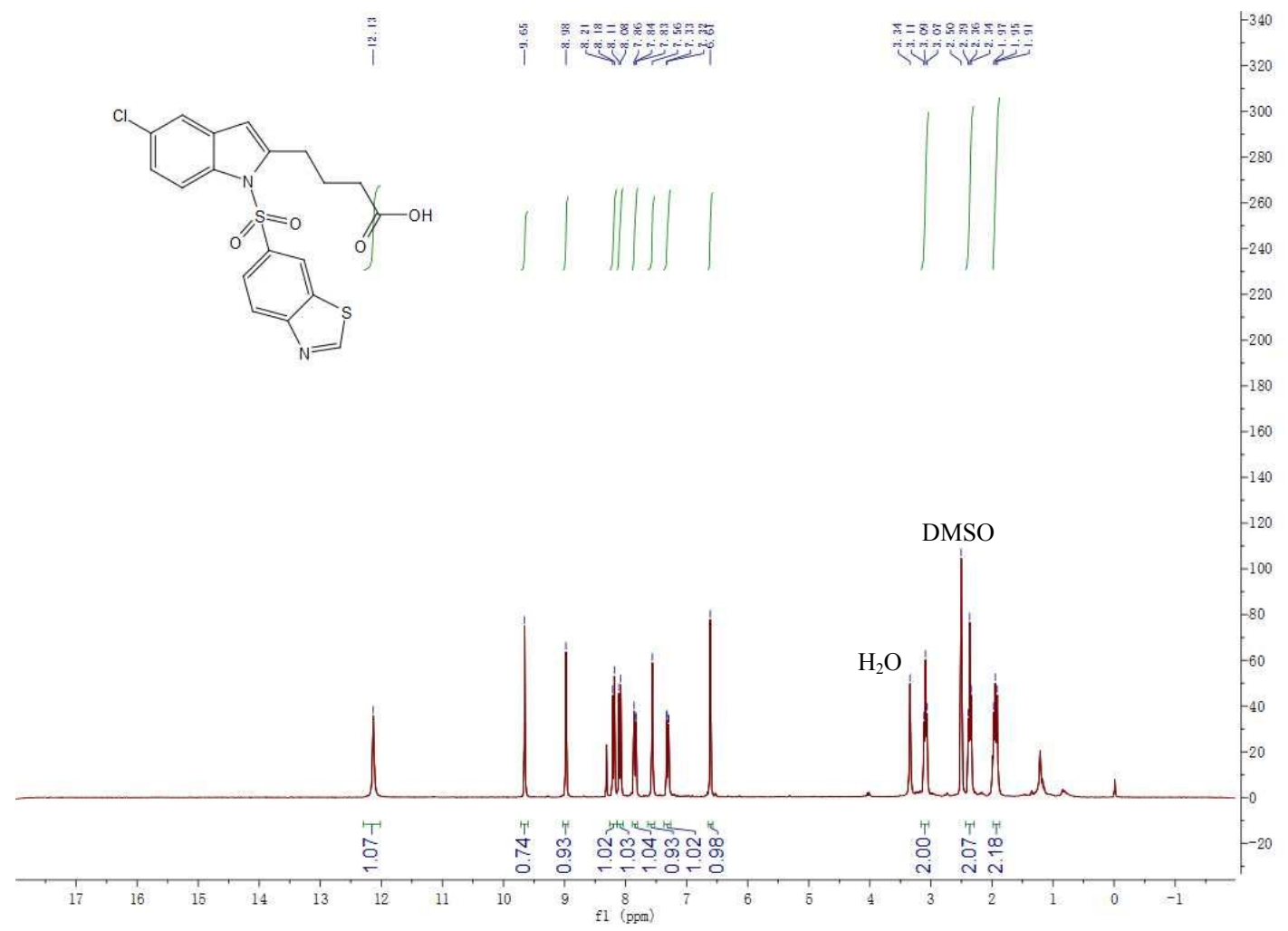


${ }^{1} \mathrm{H}-\mathrm{NMR}$ spectrum (DMSO-d6, $300 \mathrm{MHz}$ ) of 8

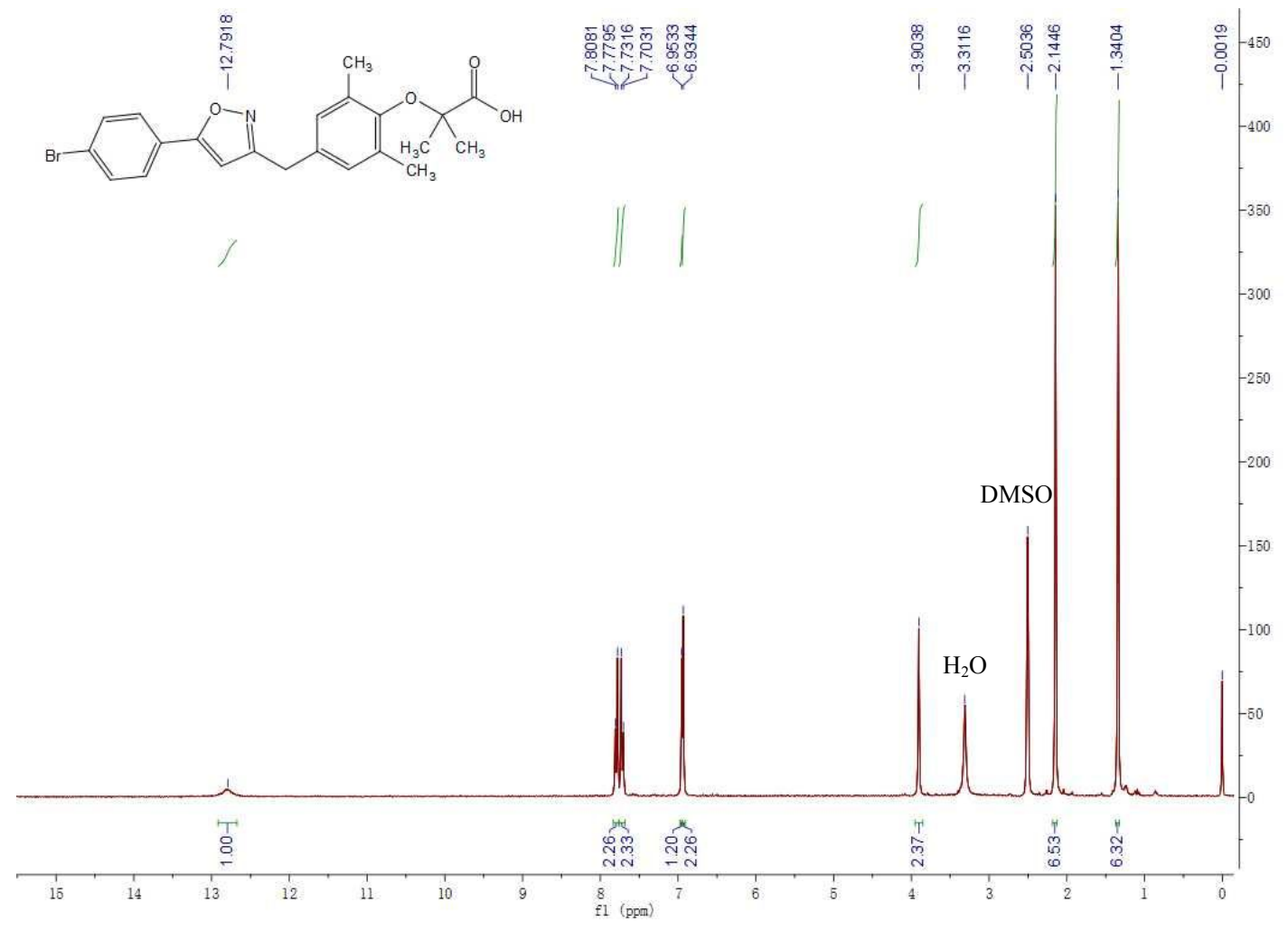




\section{UPLC Data of Compounds H0-42}

UPLC data of compound $\mathrm{H} 0$

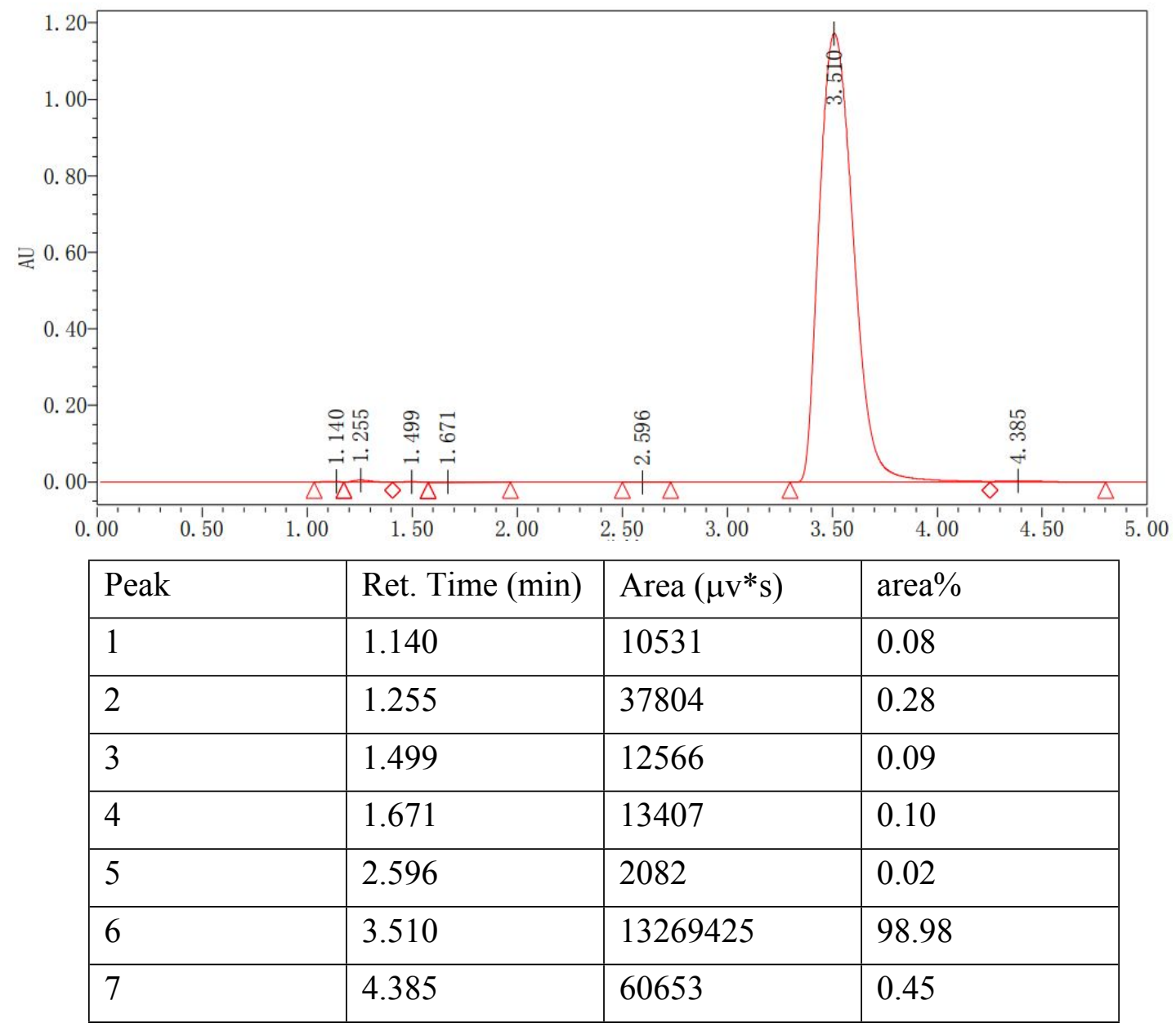


UPLC data of compound H1

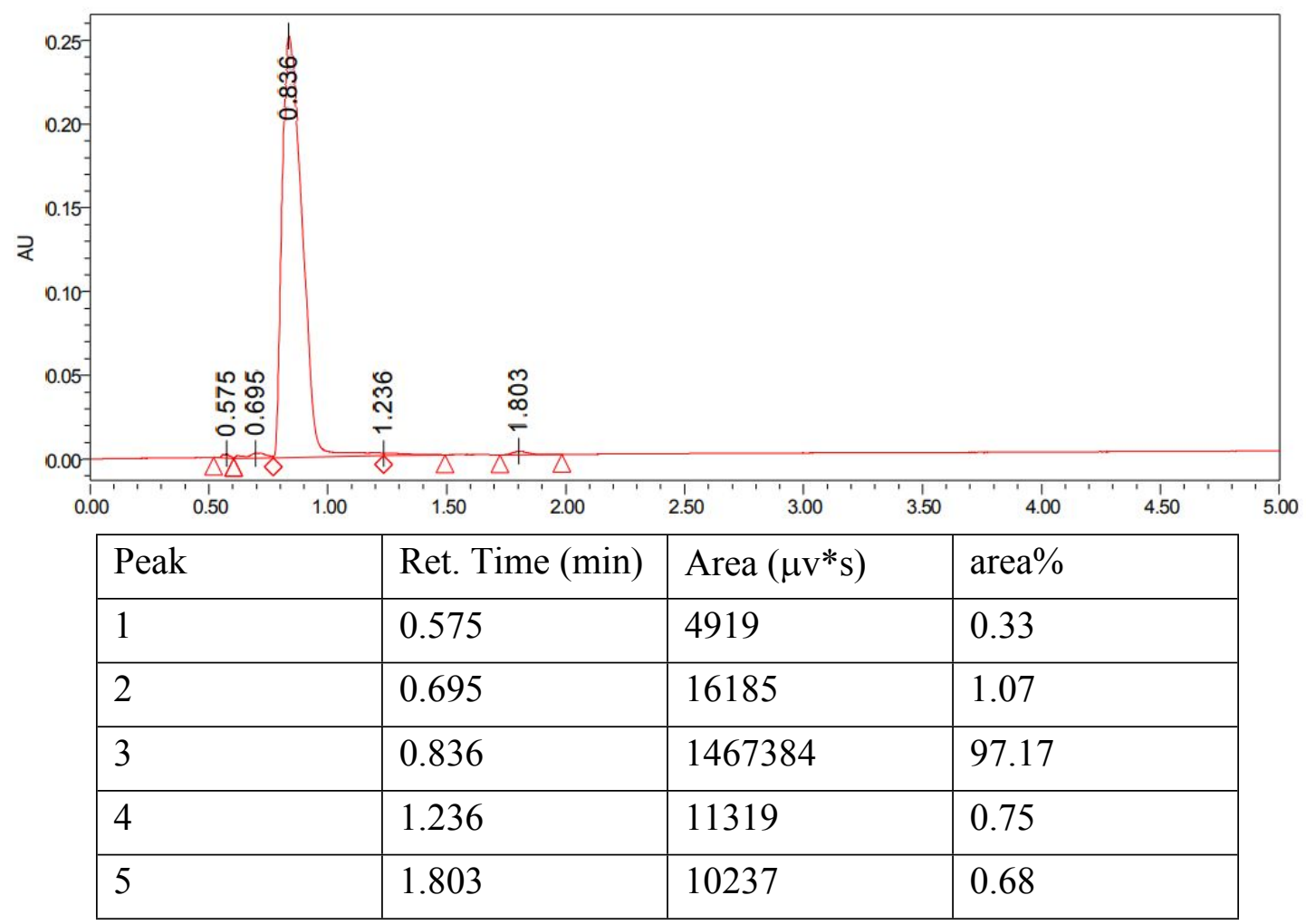

UPLC data of compound H2

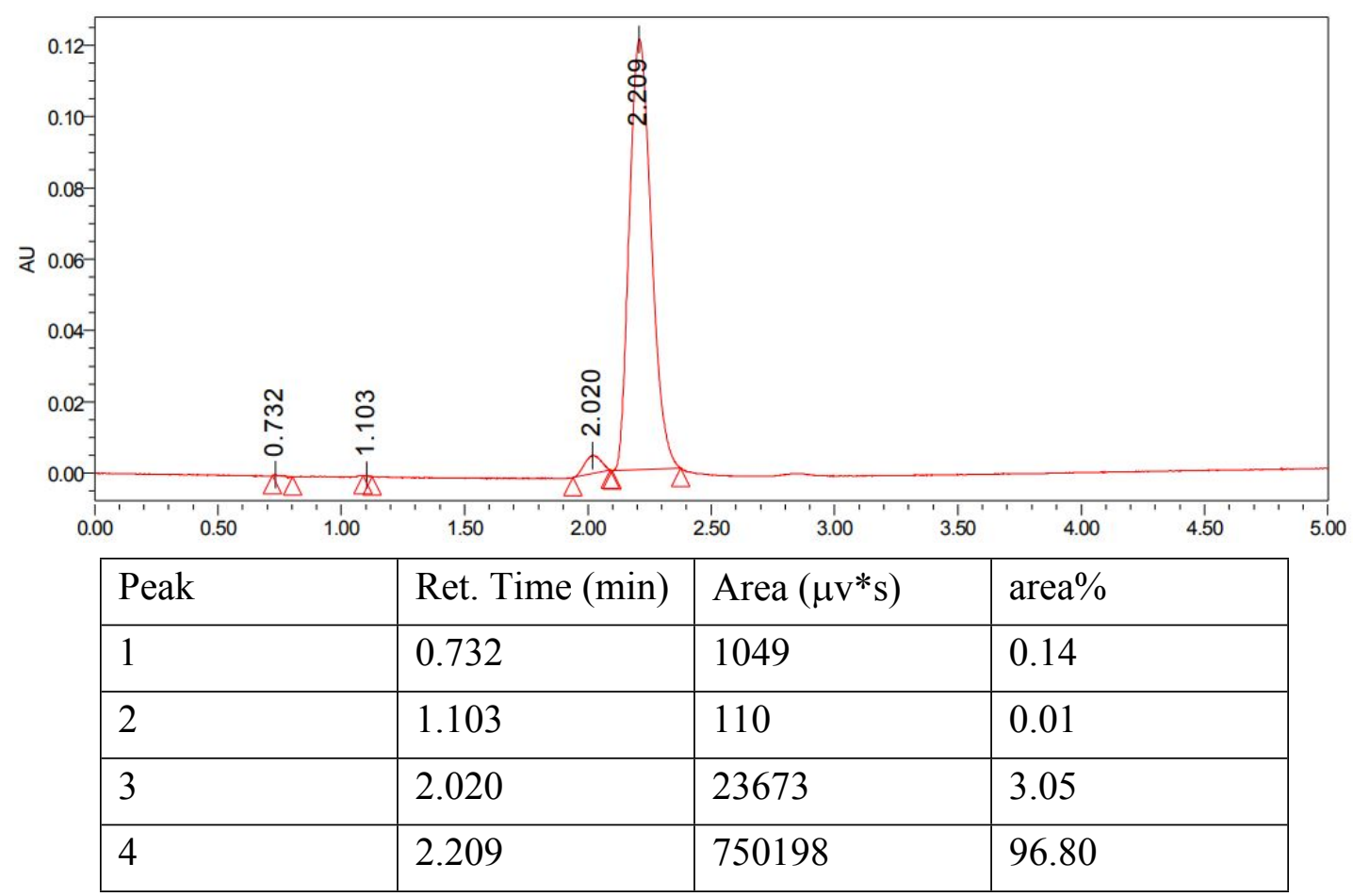


UPLC data of compound H3

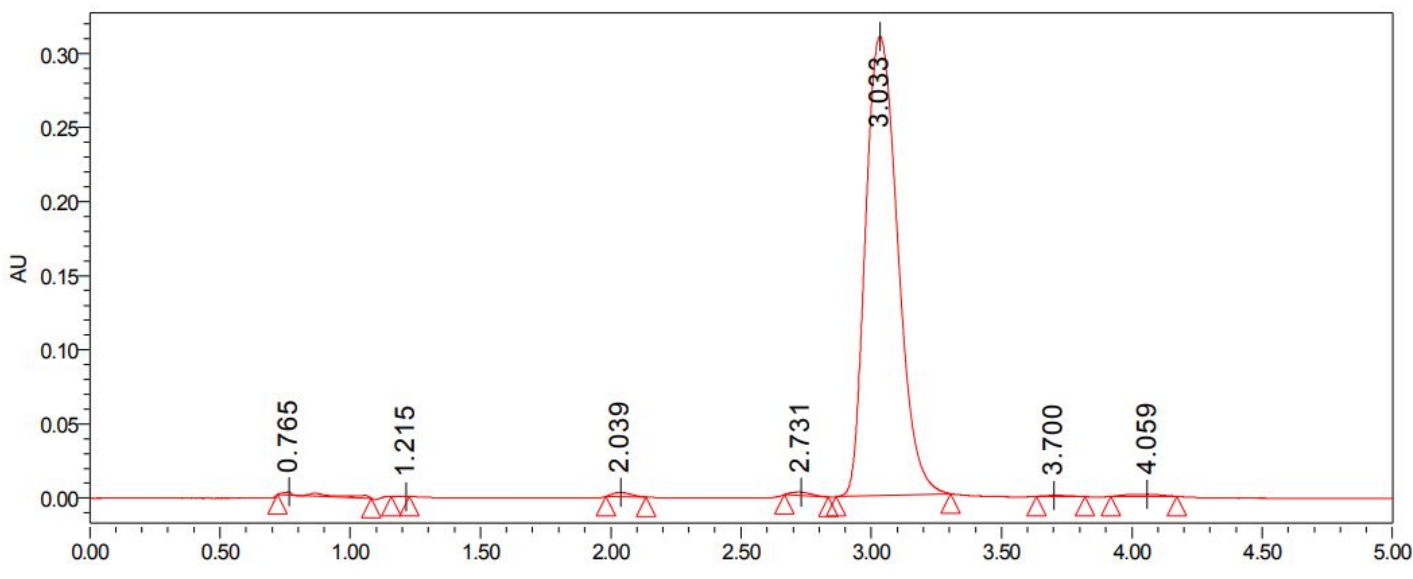

\begin{tabular}{|l|l|l|l|}
\hline Peak & Ret. Time (min) & Area $\left(\mu \mathrm{v}^{*} \mathrm{~s}\right)$ & area $\%$ \\
\hline 1 & 0.765 & 25677 & 0.94 \\
\hline 2 & 1.215 & 201 & 0.01 \\
\hline 3 & 2.039 & 13335 & 0.49 \\
\hline 4 & 2.731 & 12354 & 0.45 \\
\hline 5 & 3.033 & 2652772 & 97.37 \\
\hline 6 & 3.700 & 5076 & 0.19 \\
\hline 7 & $4 .-59$ & 14980 & 0.55 \\
\hline
\end{tabular}


UPLC data of compound H4

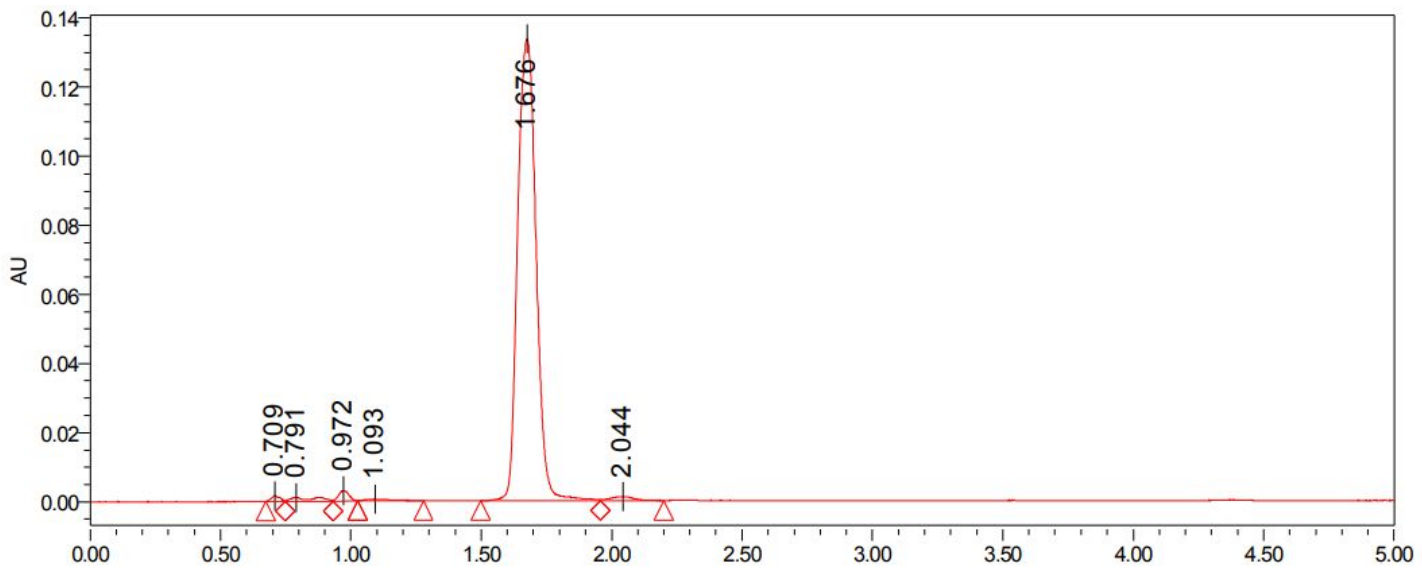

\begin{tabular}{|l|l|l|l|}
\hline Peak & Ret. Time (min) & Area $\left(\mu \mathrm{v}^{*} \mathrm{~s}\right)$ & area $\%$ \\
\hline 1 & 0.709 & 3758 & 0.55 \\
\hline 2 & 0.791 & 7867 & 1.15 \\
\hline 3 & 0.972 & 8342 & 1.22 \\
\hline 4 & 1.093 & 3993 & 0.58 \\
\hline 5 & 1.676 & 653082 & 9544 \\
\hline 6 & 2.044 & 7270 & 1.06 \\
\hline
\end{tabular}

UPLC data of compound H5

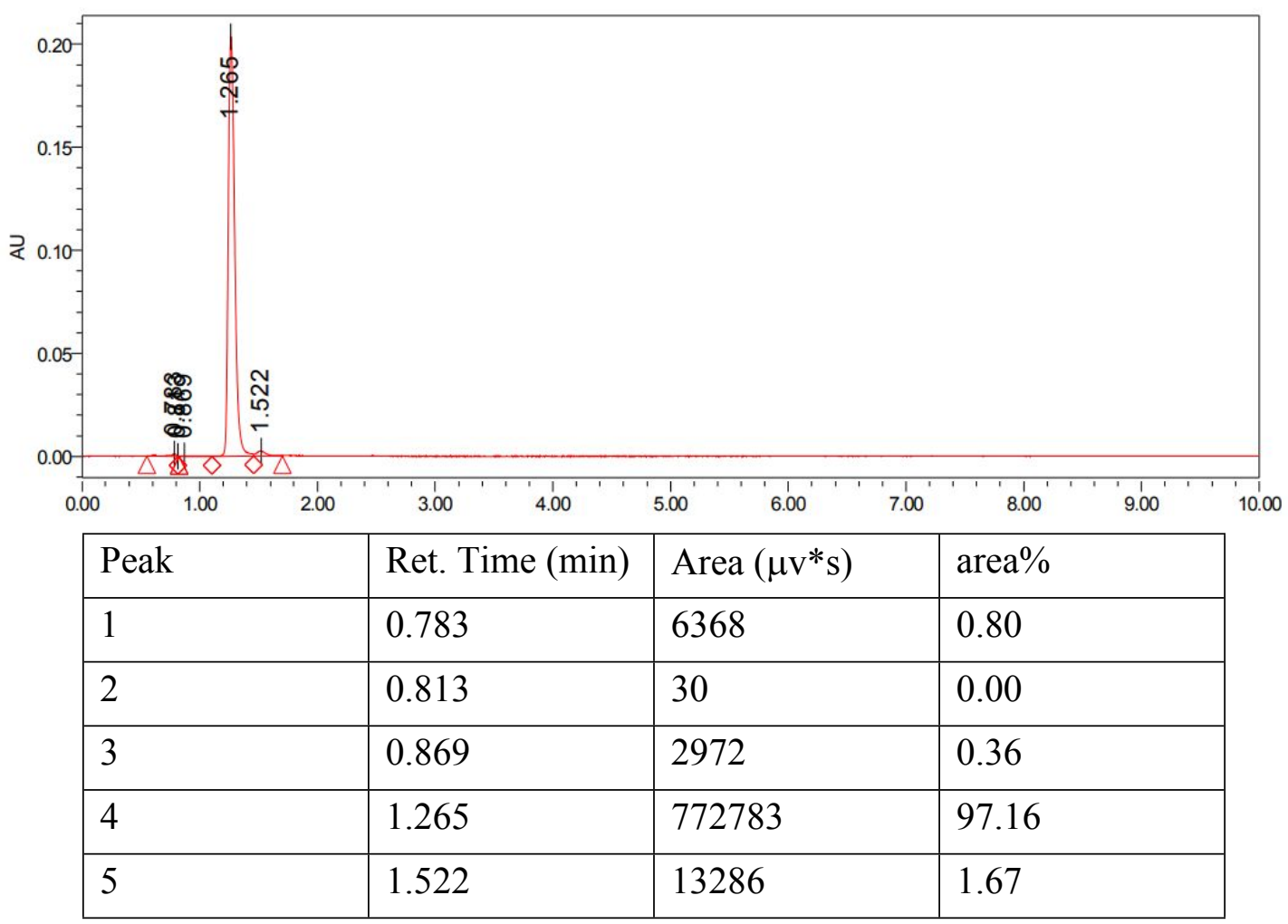


UPLC data of compound H6

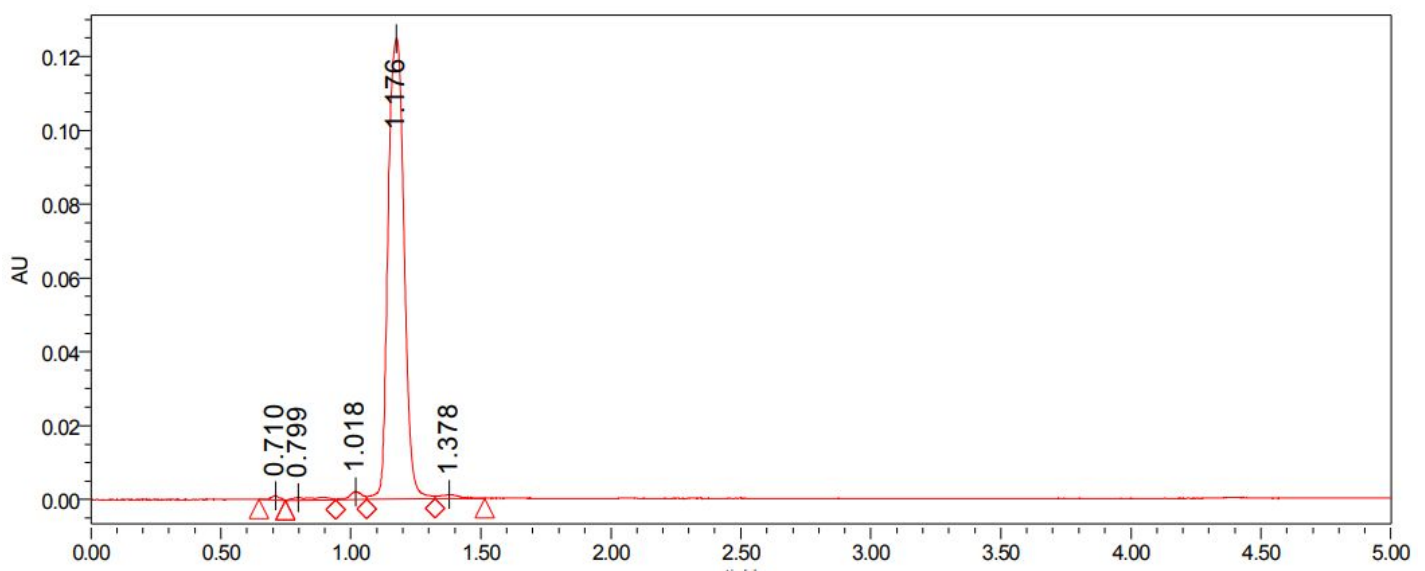

\begin{tabular}{|l|l|l|l|}
\hline Peak & Ret. Time $(\mathrm{min})$ & Area $\left(\mu \mathrm{v}^{*} \mathrm{~s}\right)$ & area $\%$ \\
\hline 1 & 0.710 & 2877 & 0.52 \\
\hline 2 & 0.799 & 6235 & 1.13 \\
\hline 3 & 1.018 & 7608 & 1.37 \\
\hline 4 & 1.176 & 530808 & 9589 \\
\hline 5 & 1.378 & 6008 & 1.09 \\
\hline
\end{tabular}

UPLC data of compound H7

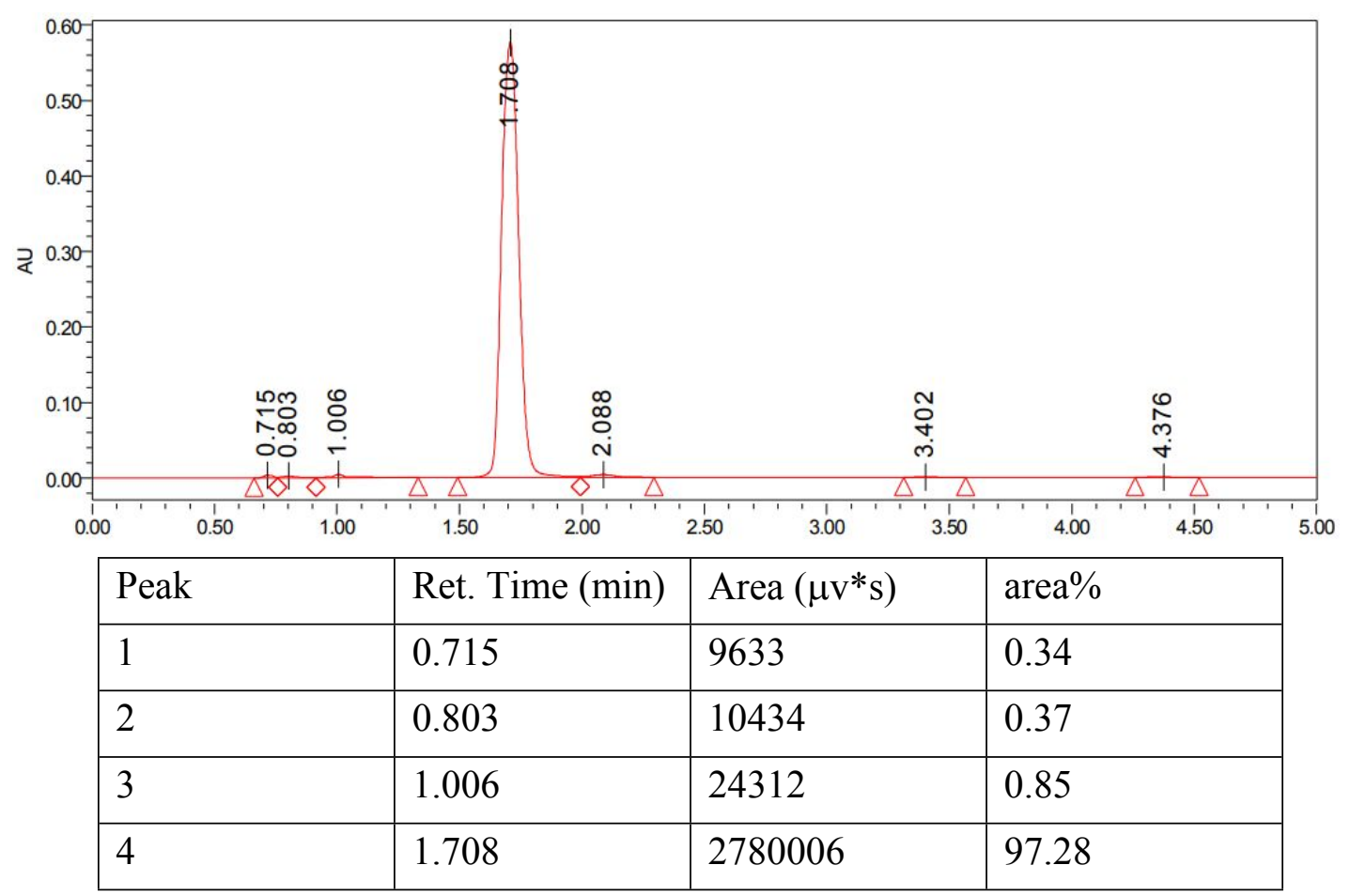




\begin{tabular}{|l|l|l|l|}
\hline 5 & 2.088 & 26410 & 0.92 \\
\hline 6 & 3.402 & 3900 & 0.14 \\
\hline 7 & 4.376 & 3143 & 0.11 \\
\hline
\end{tabular}

UPLC data of compound H8

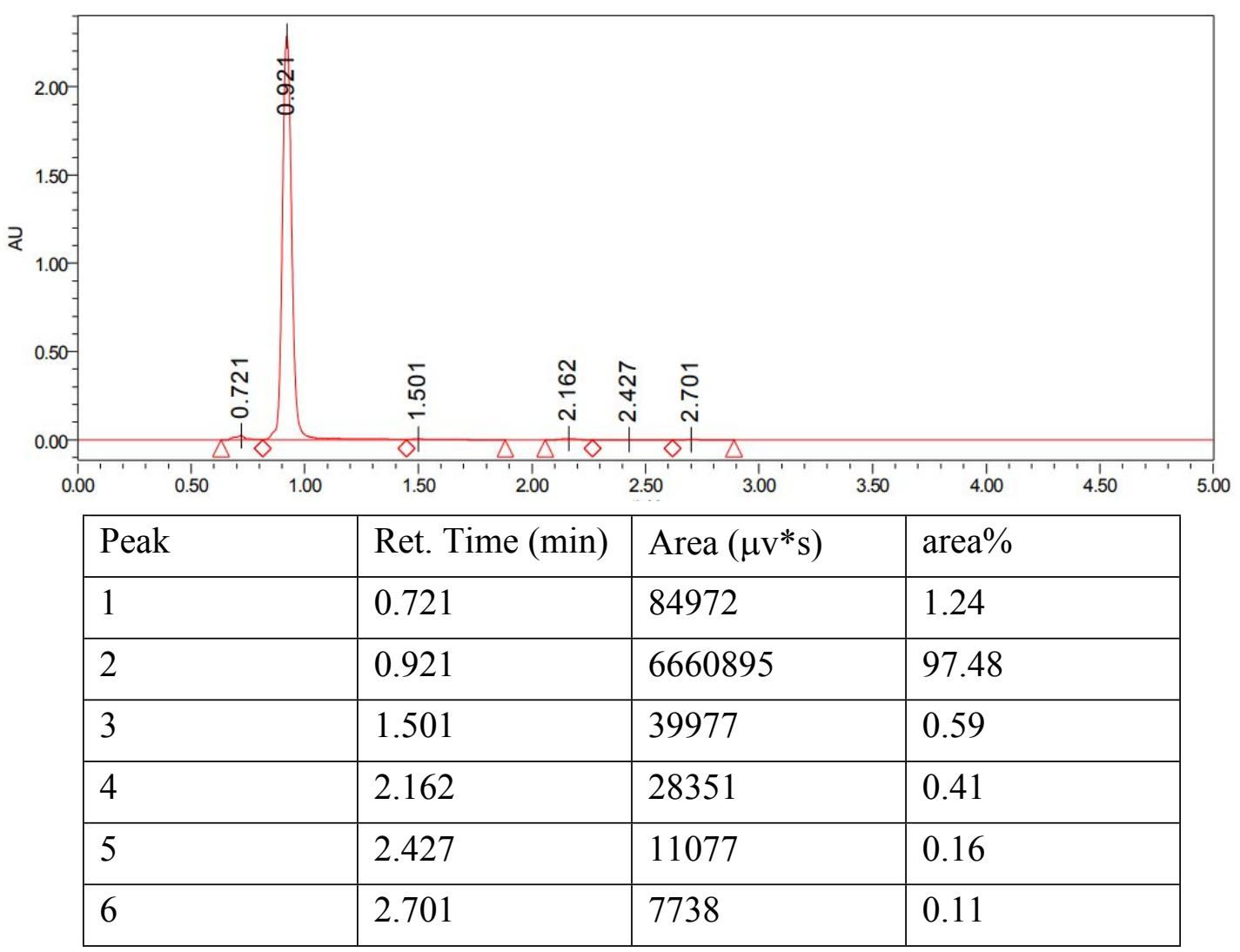


UPLC data of compound H9

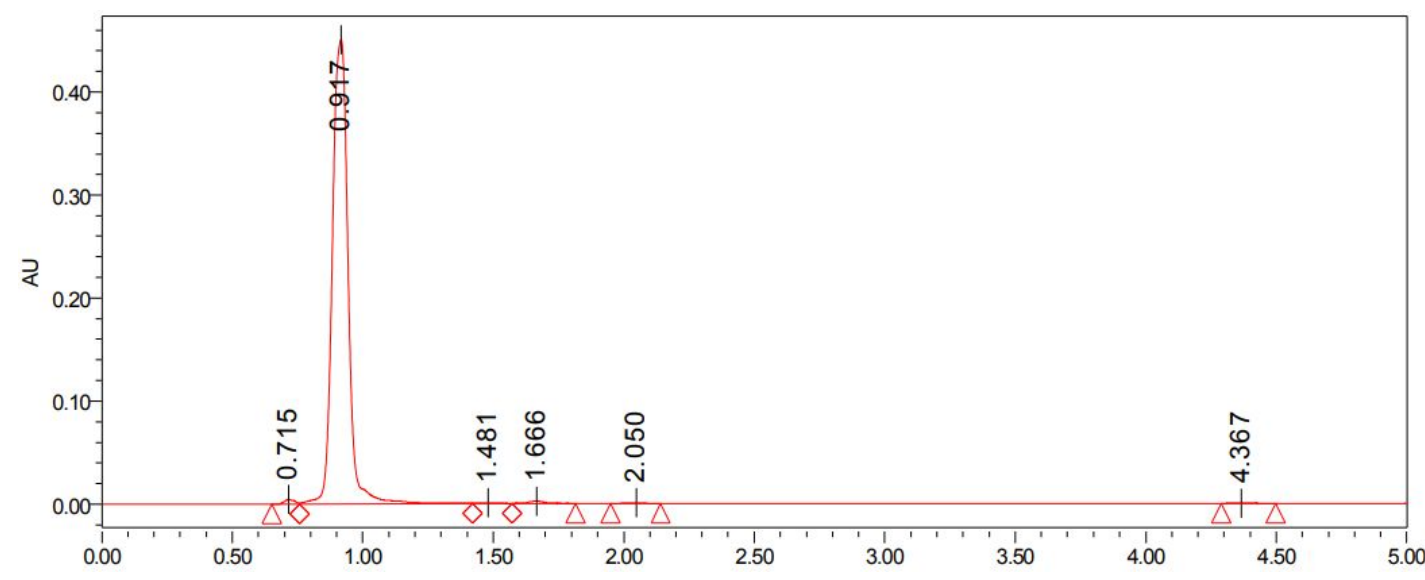

\begin{tabular}{|l|l|l|l|}
\hline Peak & Ret. Time $(\mathrm{min})$ & Area $\left(\mu \mathrm{v}{ }^{*} \mathrm{~s}\right)$ & area $\%$ \\
\hline 1 & 0.715 & 12044 & 0.62 \\
\hline 2 & 0.917 & 1900650 & 98.34 \\
\hline 3 & 1.4181 & 3987 & 0.21 \\
\hline 4 & 1.666 & 9852 & 0.51 \\
\hline 5 & 2.050 & 3773 & 0.20 \\
\hline 6 & 4.367 & 2426 & 0.13 \\
\hline
\end{tabular}


UPLC data of compound H10

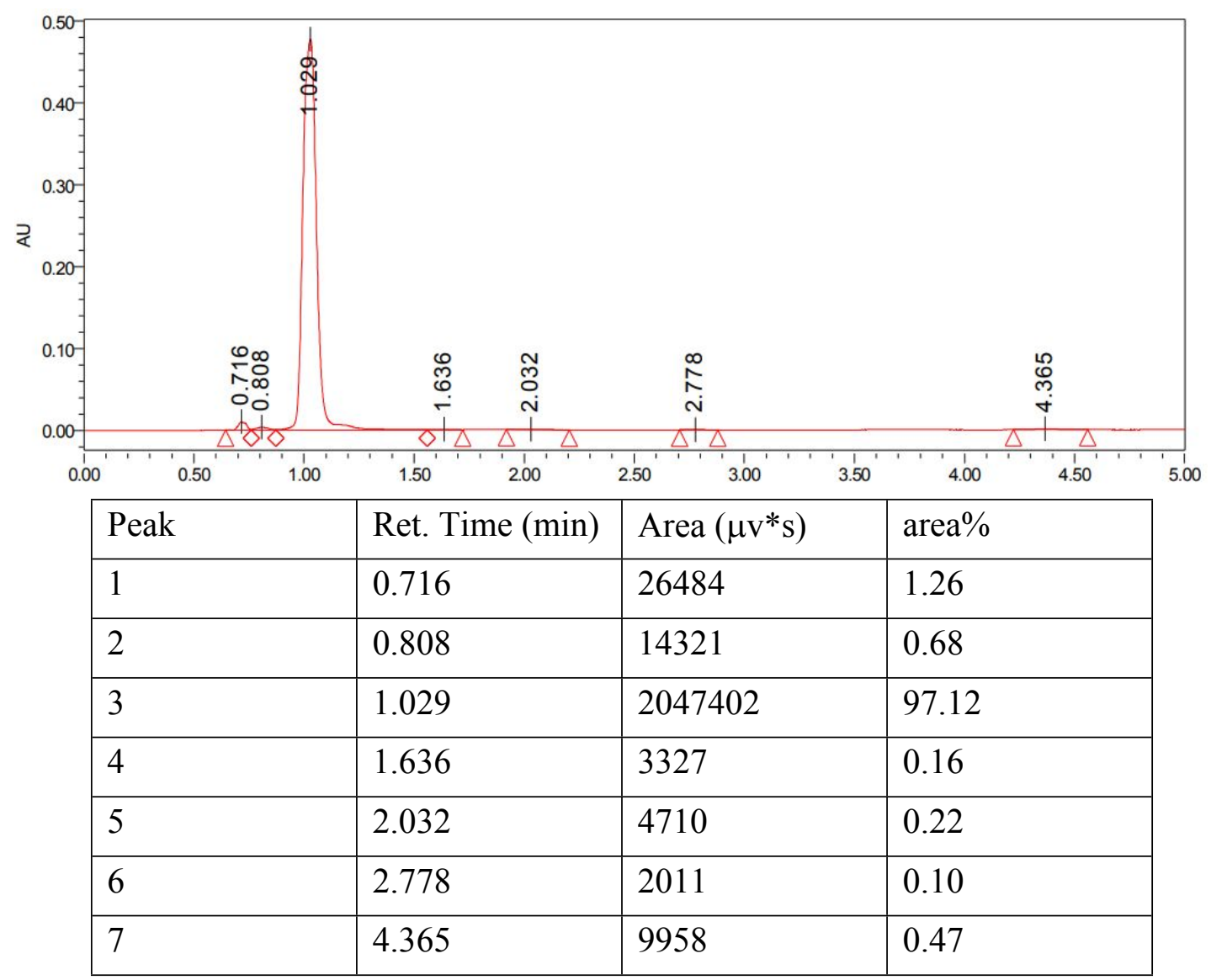

UPLC data of compound H11 


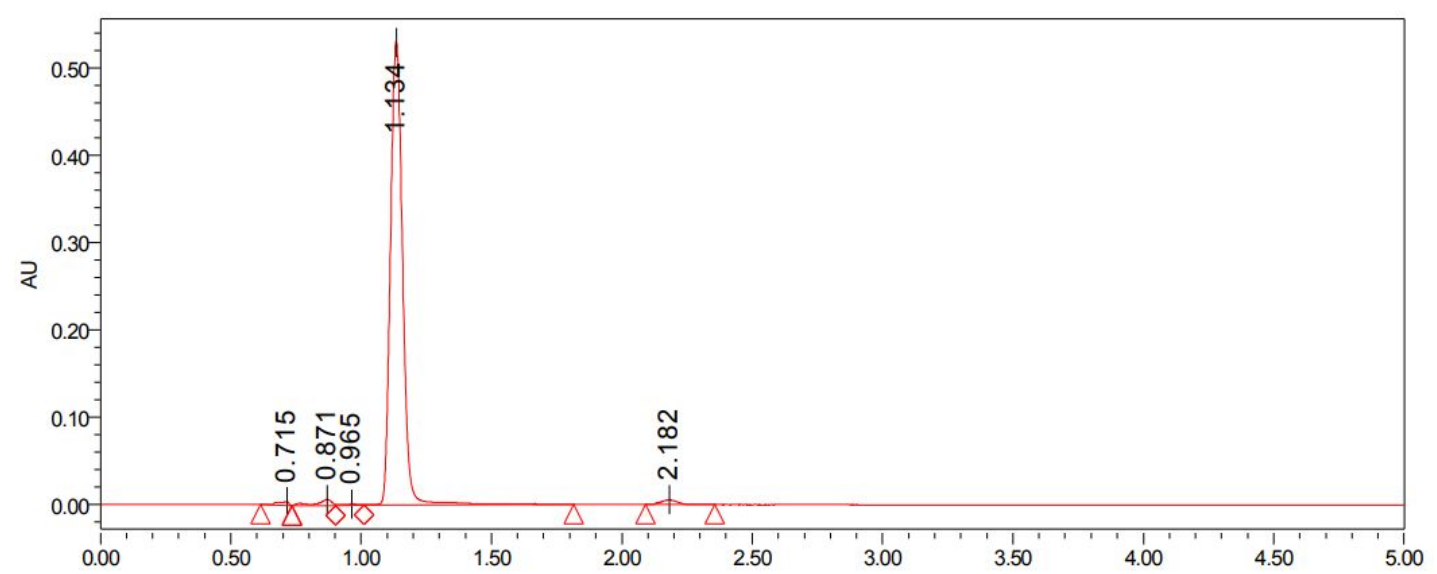

\begin{tabular}{|l|l|l|l|}
\hline Peak & Ret. Time $(\min )$ & Area $\left(\mu \mathrm{v}^{*} \mathrm{~s}\right)$ & area $\%$ \\
\hline 1 & 0.715 & 13946 & 0.77 \\
\hline 2 & 0.871 & 29073 & 1.61 \\
\hline 3 & 0.965 & 9325 & 0.52 \\
\hline 4 & 1.134 & 1724465 & 95.73 \\
\hline 5 & 2.182 & 24494 & 1.36 \\
\hline
\end{tabular}

UPLC data of compound H12

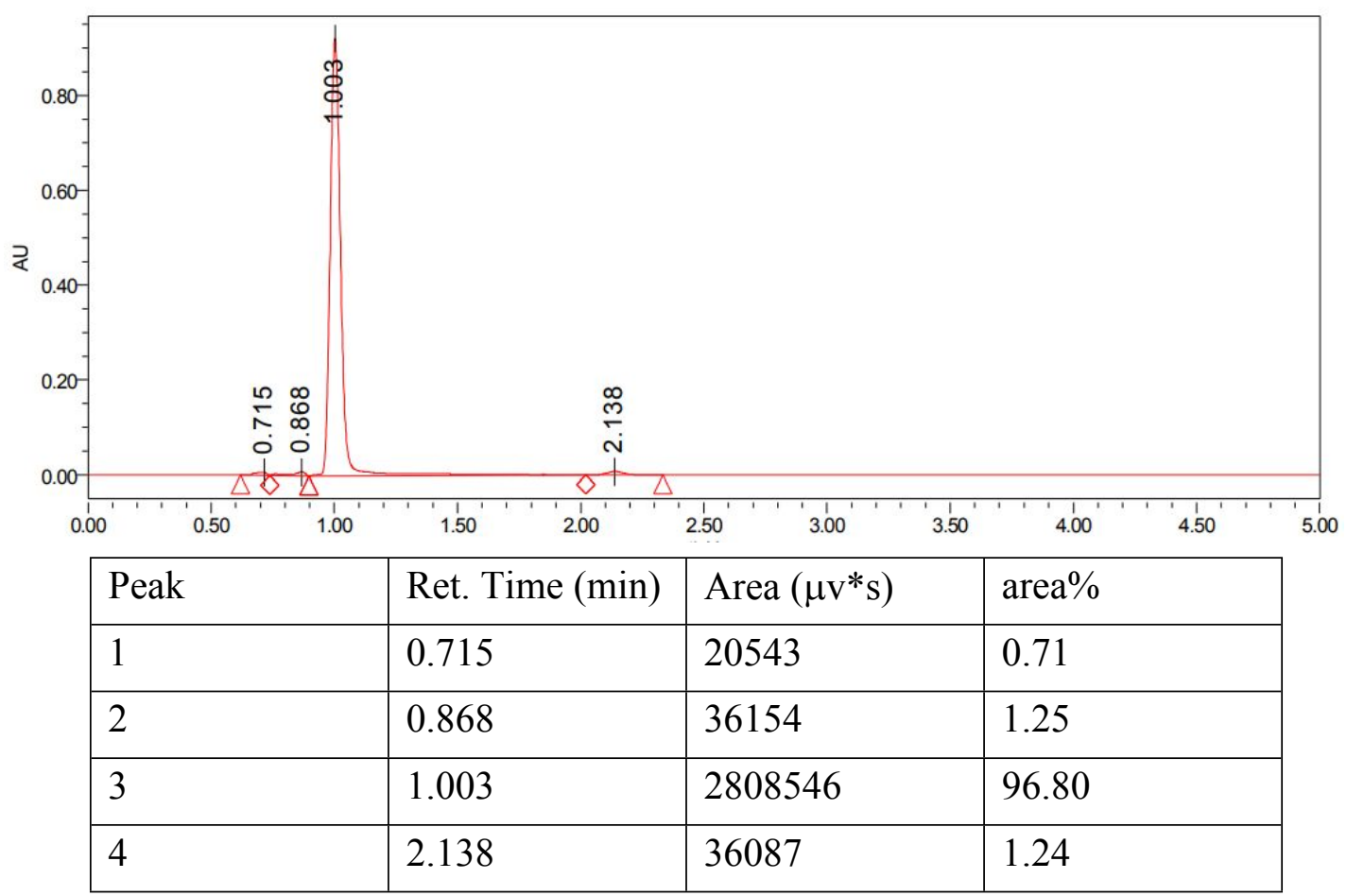

UPLC data of compound H13 


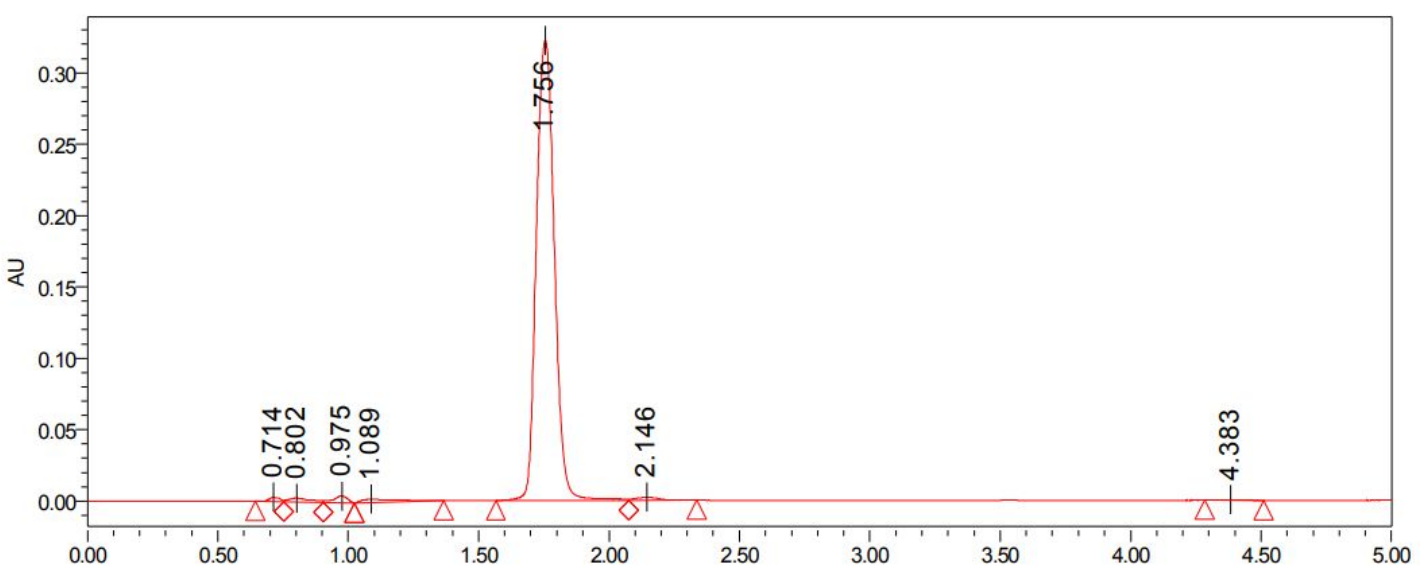

\begin{tabular}{|l|l|l|l|}
\hline Peak & Ret. Time $(\min )$ & Area $\left(\mu \mathrm{v}^{*} \mathrm{~s}\right)$ & area\% \\
\hline 1 & 0.714 & 8272 & 0.51 \\
\hline 2 & 0.802 & 15873 & 0.98 \\
\hline 3 & 0.975 & 18008 & 1.11 \\
\hline 4 & 1.089 & 22913 & 1.41 \\
\hline 5 & 1.756 & 1539859 & 95.04 \\
\hline 6 & 2.146 & 13250 & 0.82 \\
\hline 7 & 4.383 & 2076 & 0.13 \\
\hline
\end{tabular}

UPLC data of compound H14

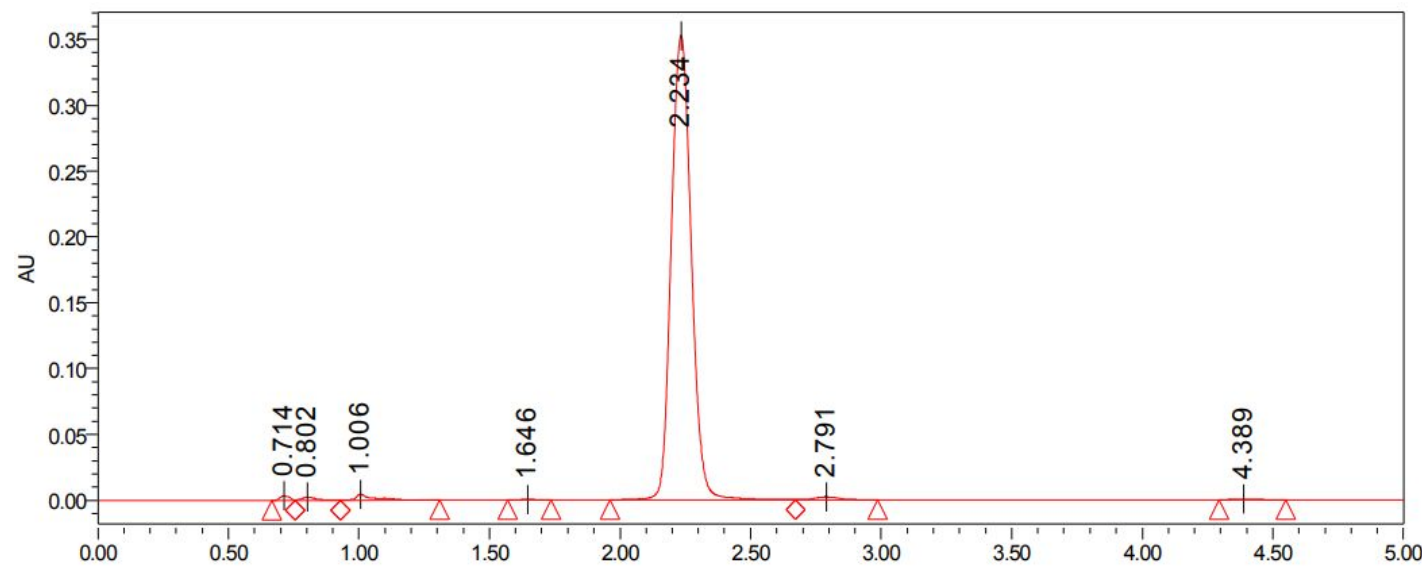

\begin{tabular}{|l|l|l|l|}
\hline Peak & Ret. Time $(\mathrm{min})$ & Area $\left(\mu \mathrm{v}^{*} \mathrm{~s}\right)$ & $\operatorname{area} \%$ \\
\hline 1 & 0.714 & 9022 & 0.46 \\
\hline 2 & 0.802 & 10162 & 0.52 \\
\hline 3 & 1.006 & 23429 & 1.19 \\
\hline 4 & 1.646 & 2457 & 0.13 \\
\hline 5 & 2.234 & 1895819 & 96.69 \\
\hline
\end{tabular}




\begin{tabular}{|l|l|l|l|}
\hline 6 & 2.791 & 16016 & 0.82 \\
\hline 7 & 4.389 & 3890 & 0.20 \\
\hline
\end{tabular}


UPLC data of compound H15

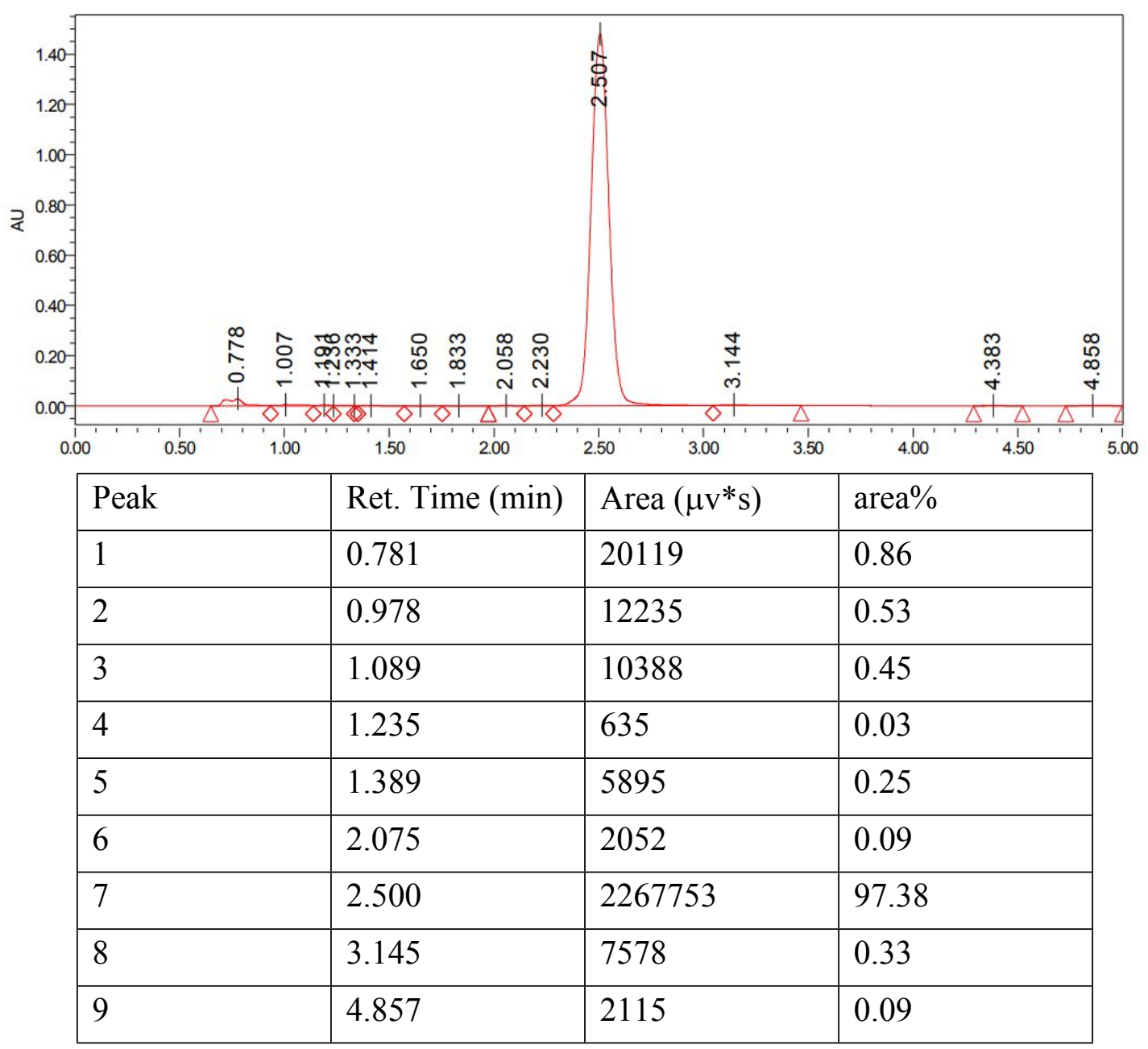


UPLC data of compound H16

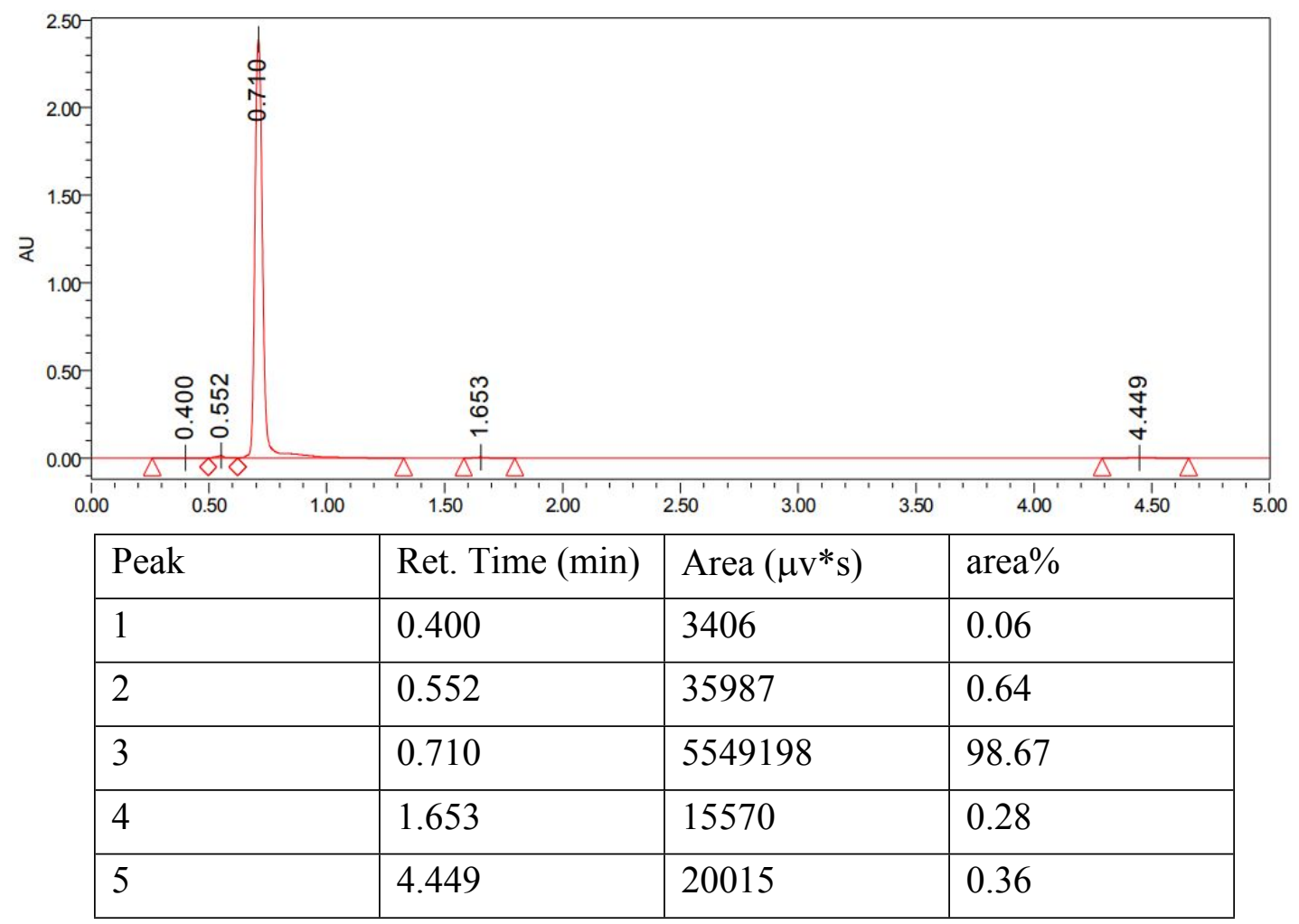

UPLC data of compound H17

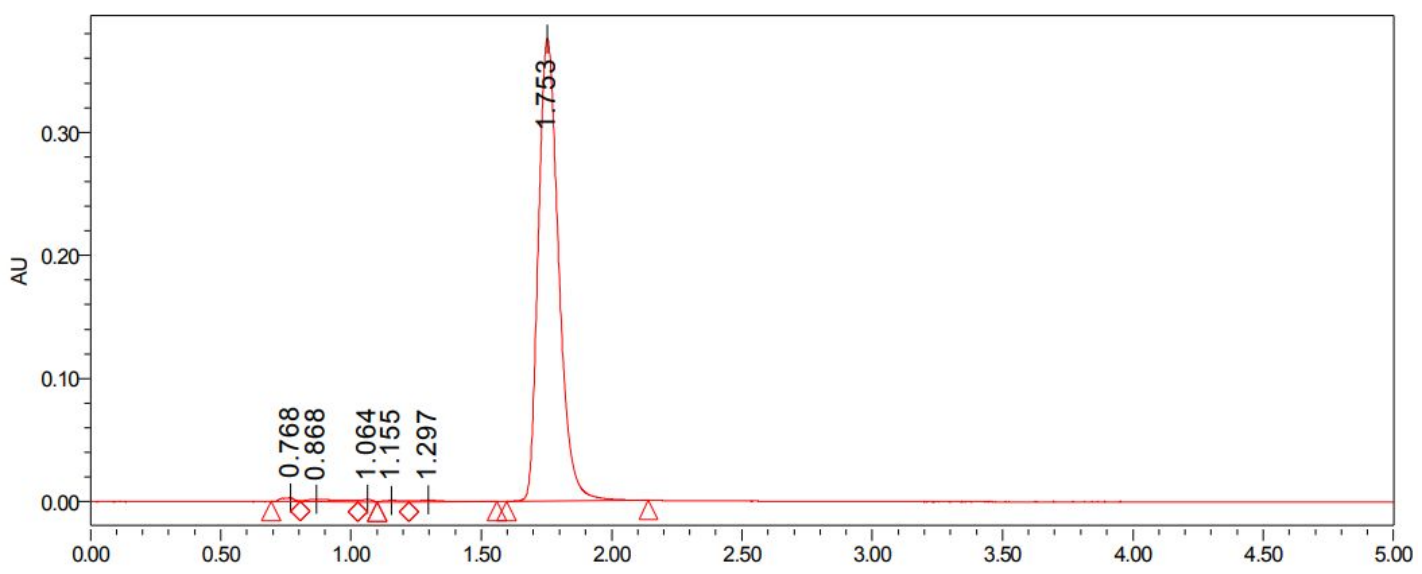

\begin{tabular}{|l|l|l|l|}
\hline Peak & Ret. Time $(\mathrm{min})$ & Area $\left(\mu \mathrm{v} \mathrm{s}^{\mathrm{s}}\right)$ & area $\%$ \\
\hline 1 & 0.768 & 11935 & 0.57 \\
\hline 2 & 0.868 & 20554 & 0.99 \\
\hline 3 & 1.064 & 5915 & 0.28 \\
\hline 4 & 1.155 & 6175 & 0.30 \\
\hline 5 & 1.297 & 9709 & 0.47 \\
\hline 6 & 1.753 & 2024021 & 97.39 \\
\hline
\end{tabular}


UPLC data of compound H18

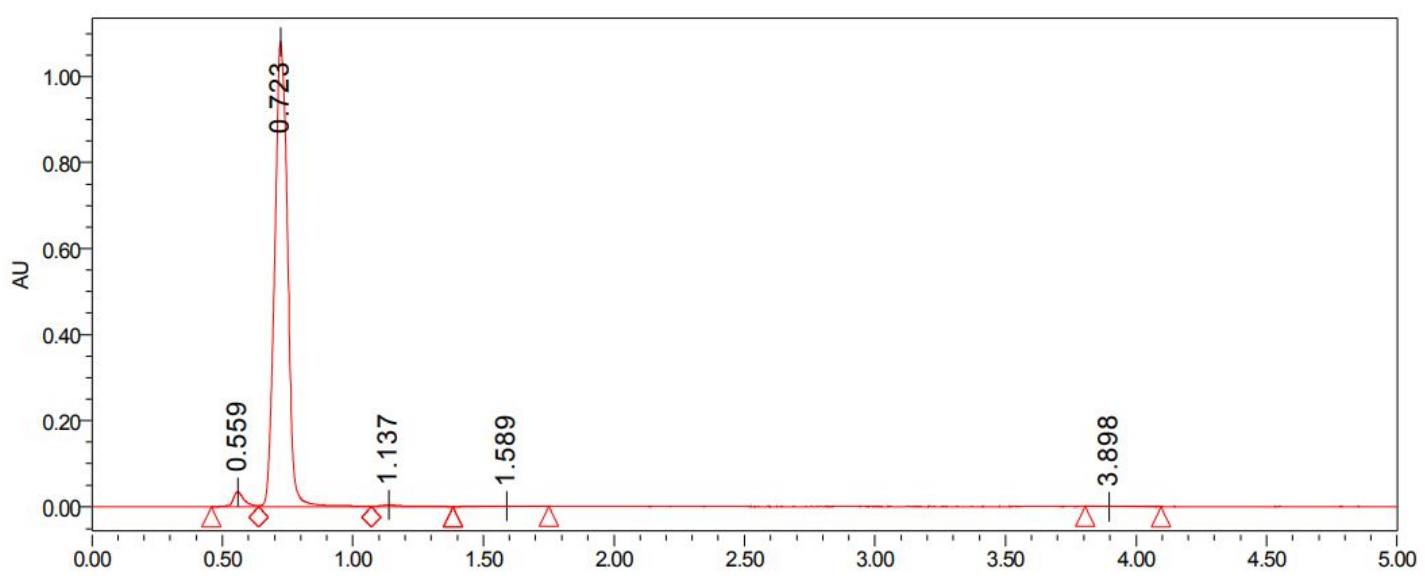

\begin{tabular}{|l|l|l|l|}
\hline Peak & Ret. Time $(\mathrm{min})$ & Area $\left(\mu \mathrm{v} \mathrm{s}^{\mathrm{s}}\right)$ & area $\%$ \\
\hline 1 & 0.751 & 4248951 & 96.62 \\
\hline 2 & 1.035 & 69391 & 1.58 \\
\hline 3 & 1.073 & 34234 & 0.78 \\
\hline 4 & 1.236 & 21235 & 0.48 \\
\hline 5 & 1.431 & 8843 & 0.20 \\
\hline 6 & 2.945 & 10755 & 0.24 \\
\hline 7 & 3.289 & 4305 & 0.10 \\
\hline
\end{tabular}

UPLC data of compound H19

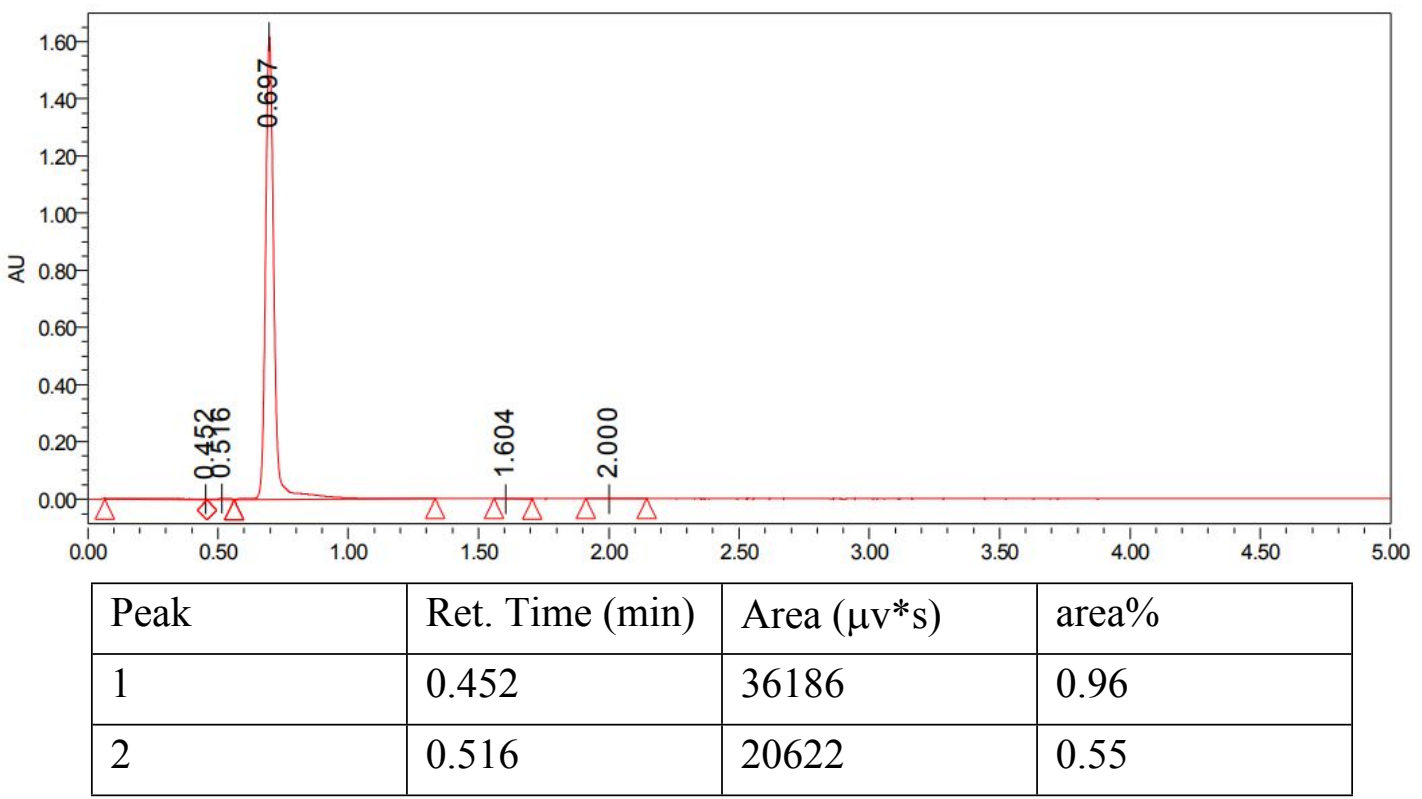




\begin{tabular}{|l|l|l|l|}
\hline 3 & 0.697 & 3715903 & 98.36 \\
\hline 4 & 1.604 & 1630 & 0.04 \\
\hline 5 & 2.000 & 3541 & 0.09 \\
\hline
\end{tabular}

UPLC data of compound H20

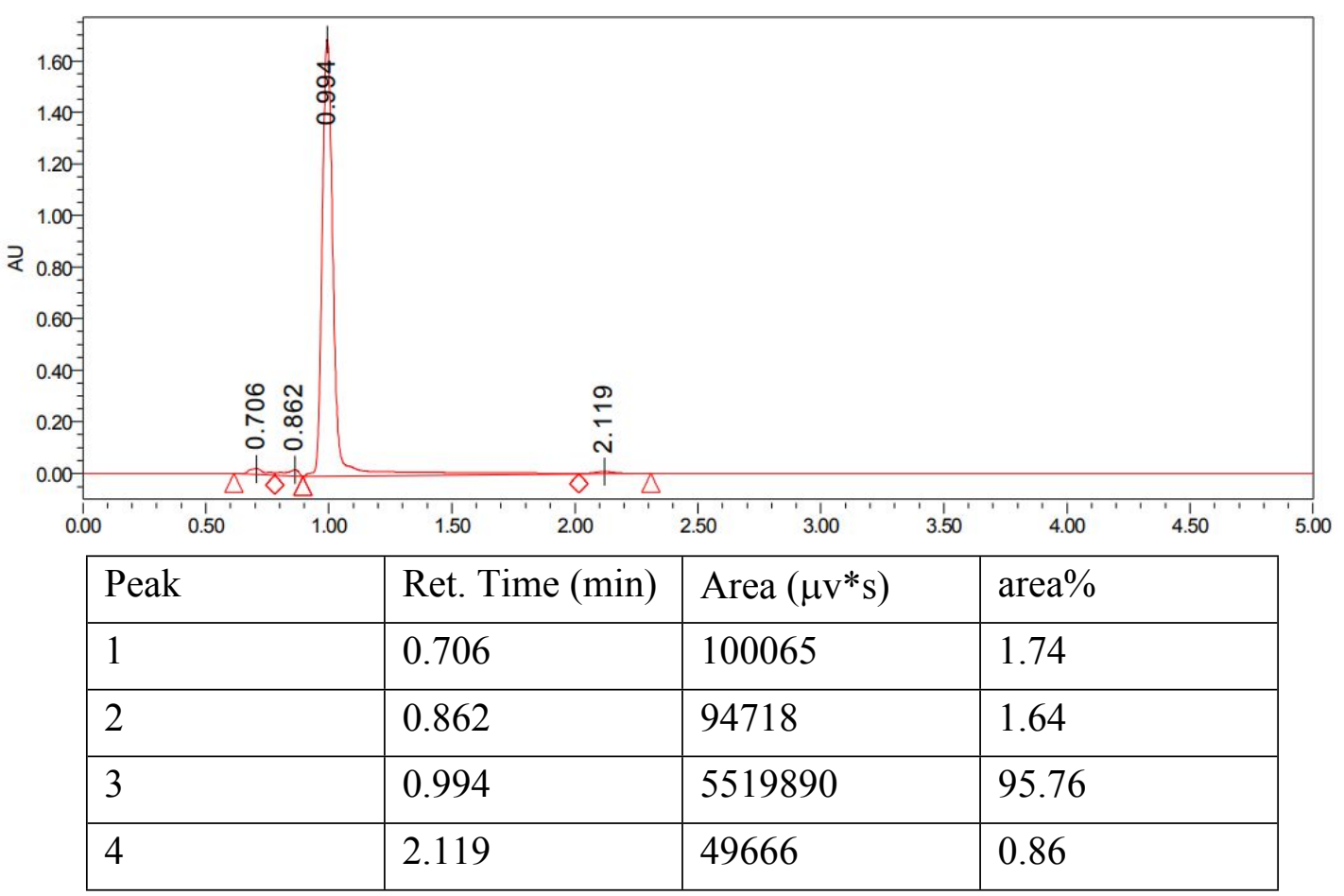

UPLC data of compound H21

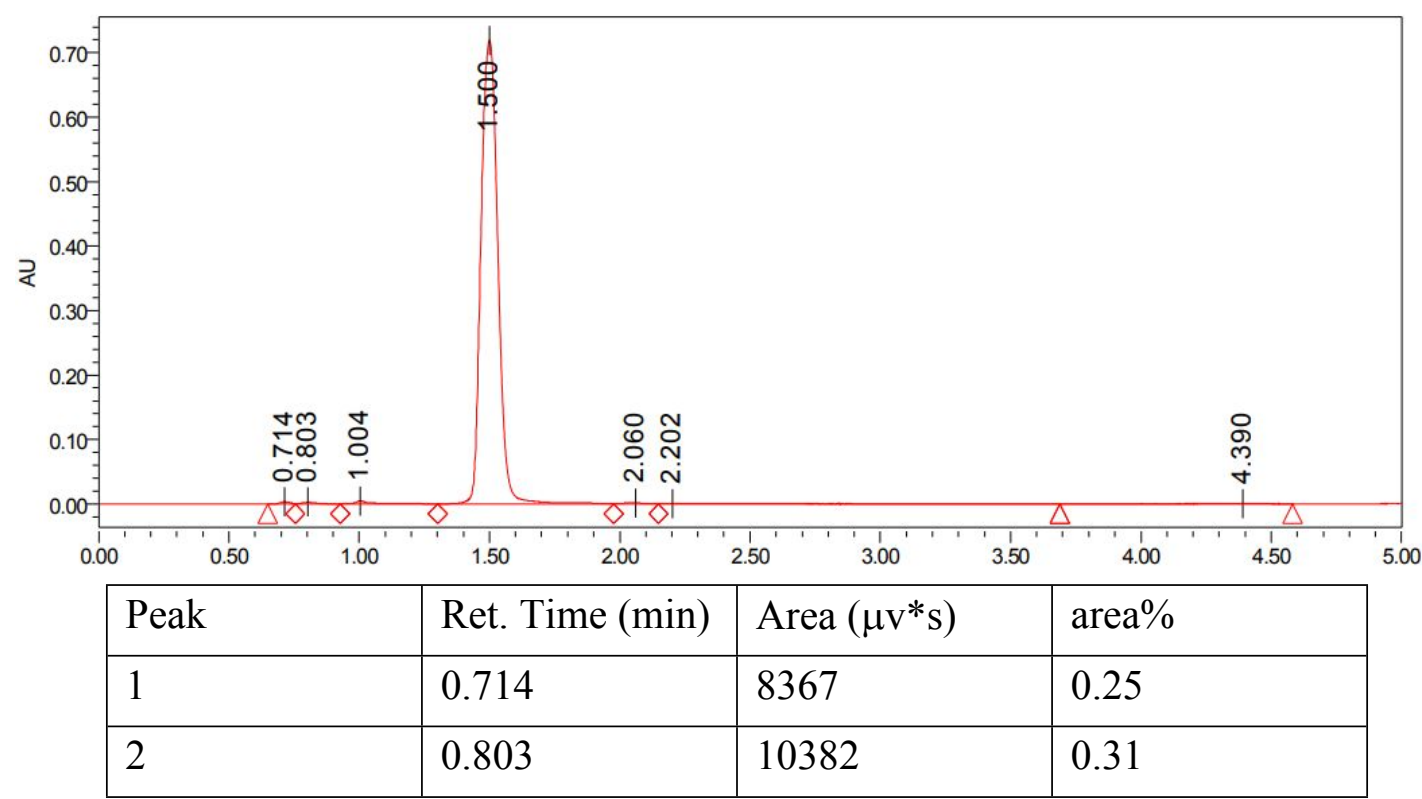




\begin{tabular}{|l|l|l|l|}
\hline 3 & 1.004 & 23850 & 0.72 \\
\hline 4 & 1.500 & 3240637 & 97.47 \\
\hline 5 & 2.060 & 10467 & 0.31 \\
\hline 6 & 2.202 & 21950 & 0.66 \\
\hline 7 & 4.390 & 8992 & 0.27 \\
\hline
\end{tabular}

UPLC data of compound H22

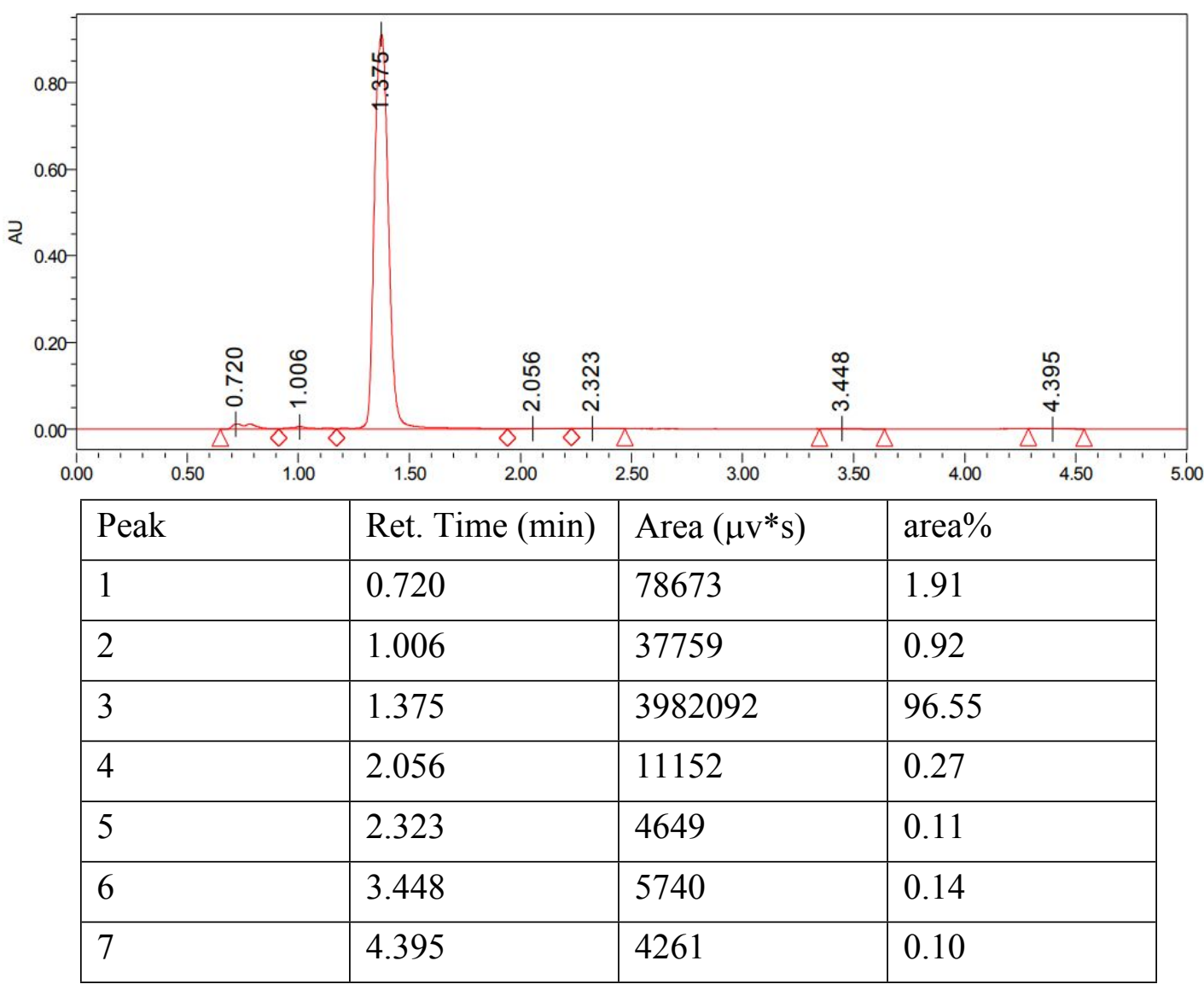


UPLC data of compound H23

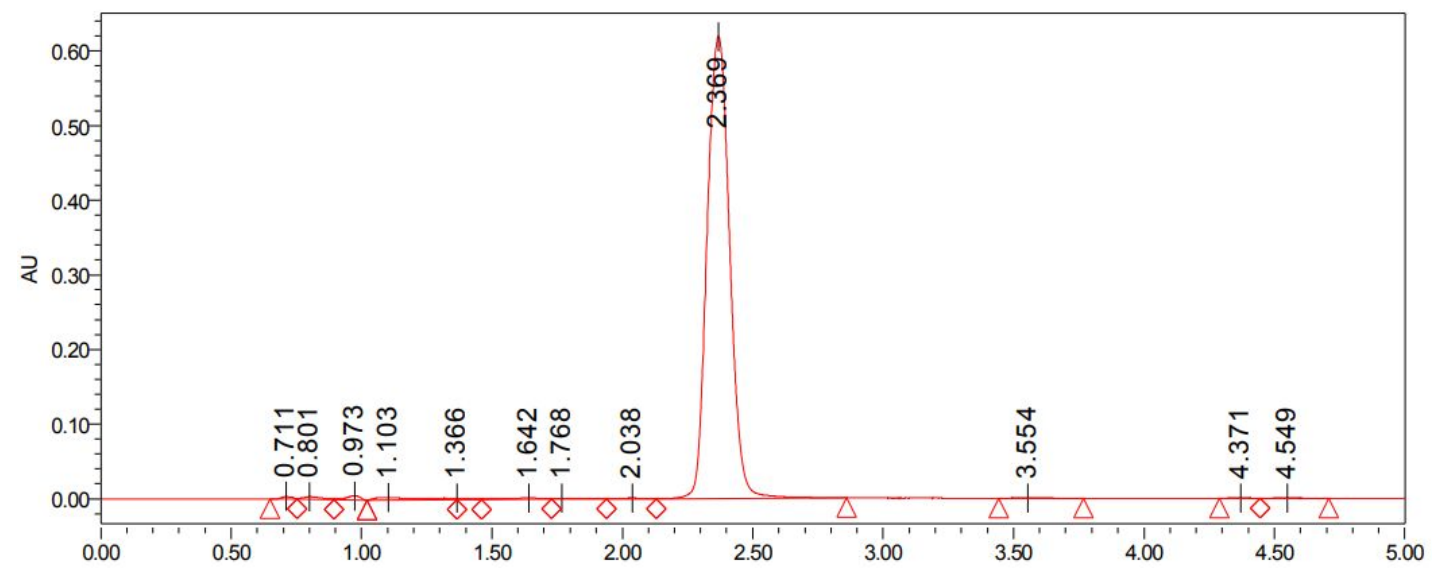

\begin{tabular}{|l|l|l|l|}
\hline Peak & Ret. Time $(\mathrm{min})$ & Area $\left(\mu \mathrm{v}^{*} \mathrm{~s}\right)$ & area\% \\
\hline 1 & 0.711 & 9413 & 0.24 \\
\hline 2 & 0.801 & 20385 & 0.52 \\
\hline 3 & 0.973 & 24100 & 0.62 \\
\hline 4 & 1.103 & 52130 & 1.34 \\
\hline 5 & 1.366 & 10026 & 0.26 \\
\hline 6 & 1.642 & 27703 & 0.71 \\
\hline 7 & 1.768 & 14523 & 0.37 \\
\hline 8 & 2.038 & 10749 & 0.28 \\
\hline 9 & 2.369 & 3713020 & 95.37 \\
\hline 10 & 3.554 & 5501 & 0.14 \\
\hline 11 & 4.371 & 1893 & 0.05 \\
\hline 12 & 4.549 & 3904 & 0.10 \\
\hline
\end{tabular}


UPLC data of compound $\mathrm{H} 24$

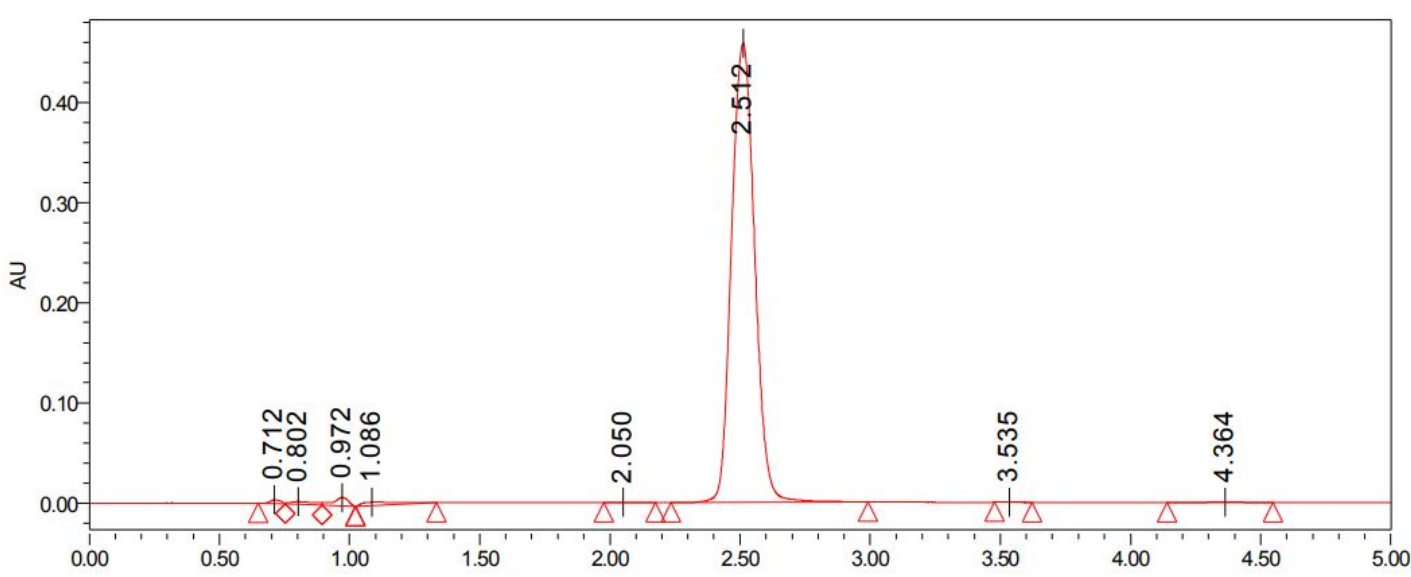

\begin{tabular}{|l|l|l|l|}
\hline Peak & Ret. Time $(\min )$ & Area $\left(\mu \mathrm{v}^{*} \mathrm{~s}\right)$ & area\% \\
\hline 1 & 0.712 & 10652 & 0.36 \\
\hline 2 & 0.802 & 19639 & 0.67 \\
\hline 3 & 0.972 & 33429 & 1.14 \\
\hline 4 & 1.086 & 34286 & 1.17 \\
\hline 5 & 2.050 & 1517 & 0.05 \\
\hline 6 & 2.512 & 2835986 & 9641 \\
\hline 7 & 3.535 & 1246 & 0.04 \\
\hline 8 & 4.364 & 4720 & 0.16 \\
\hline
\end{tabular}


UPLC data of compound H25

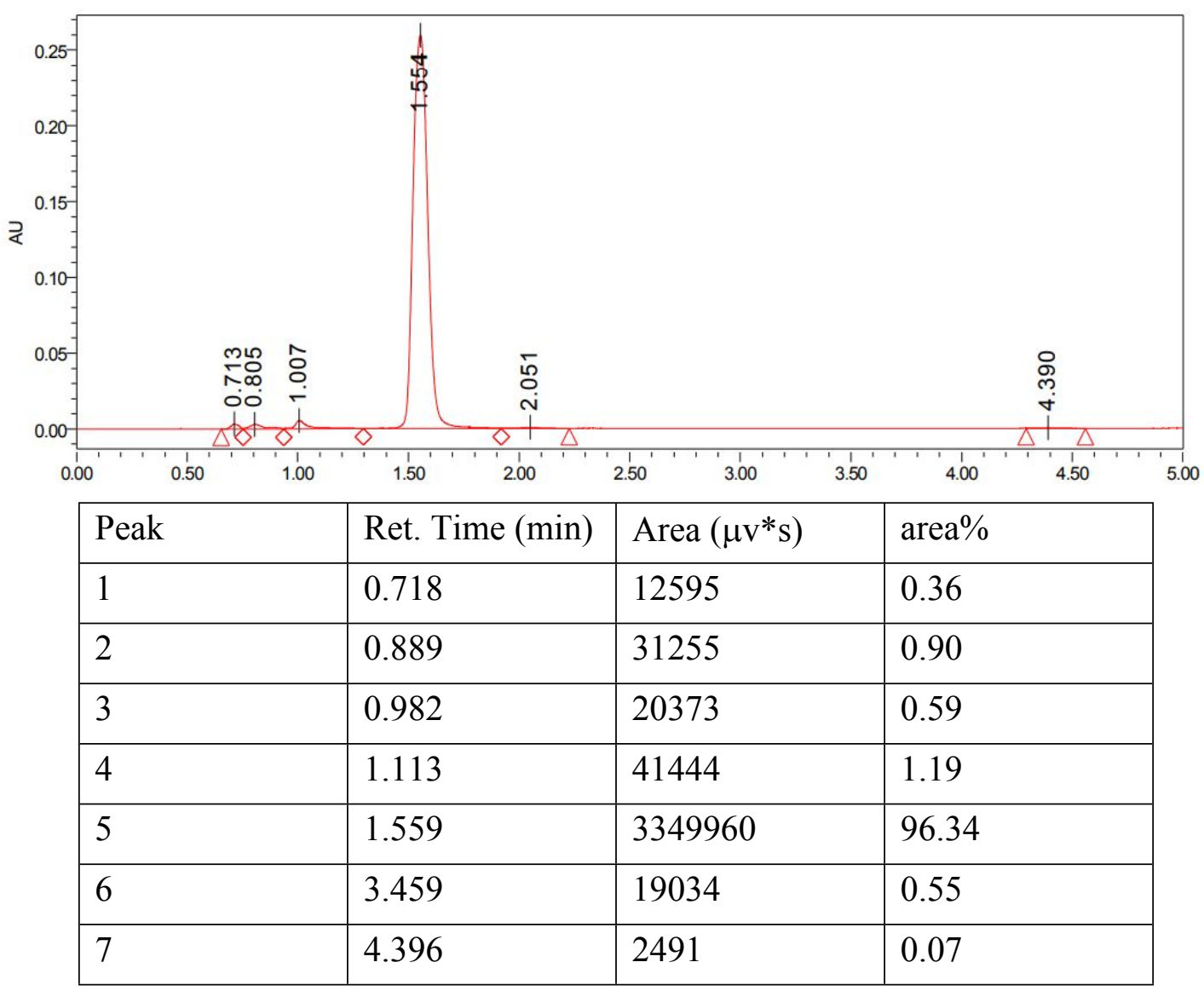


UPLC data of compound H26

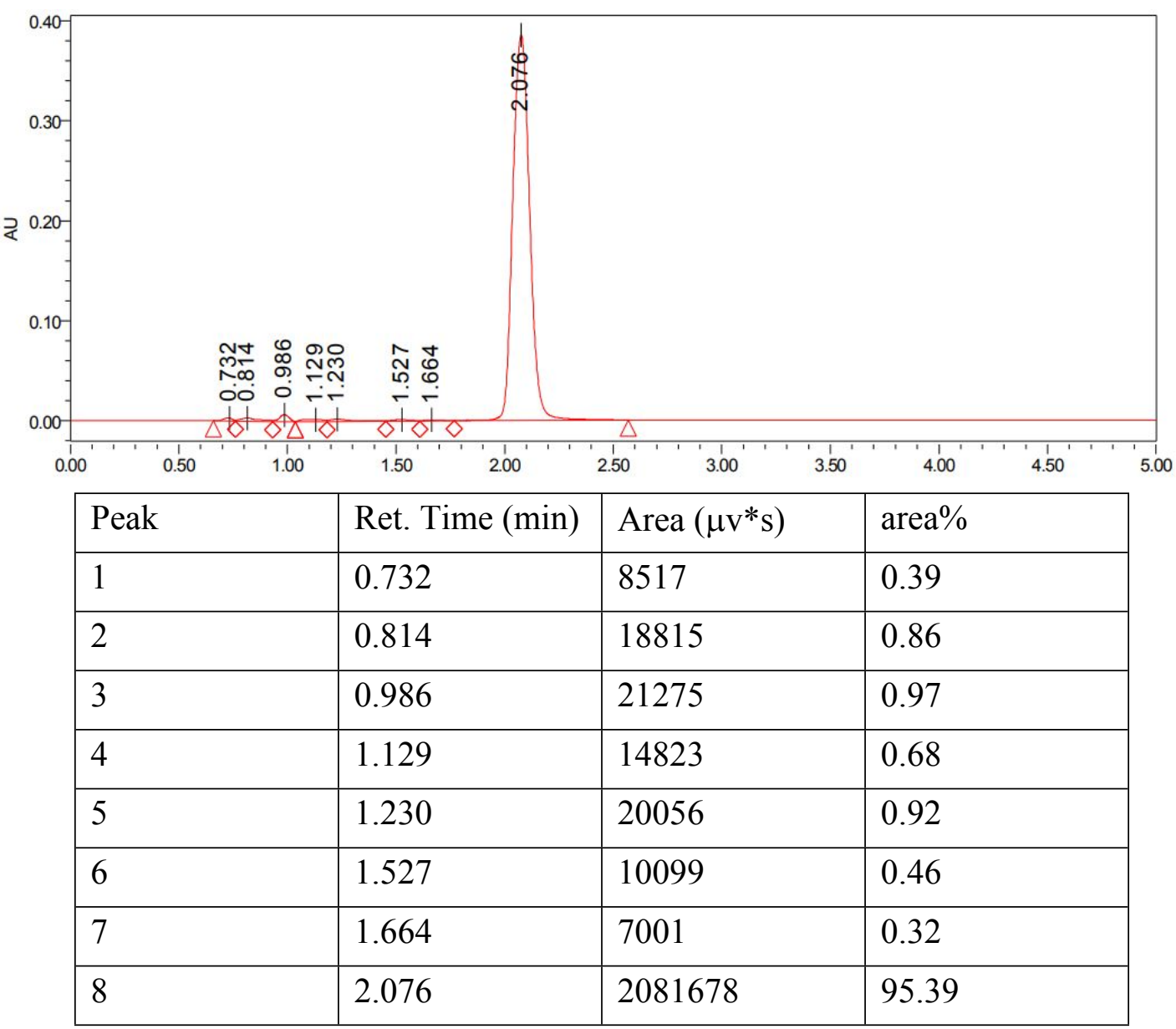


UPLC data of compound H27

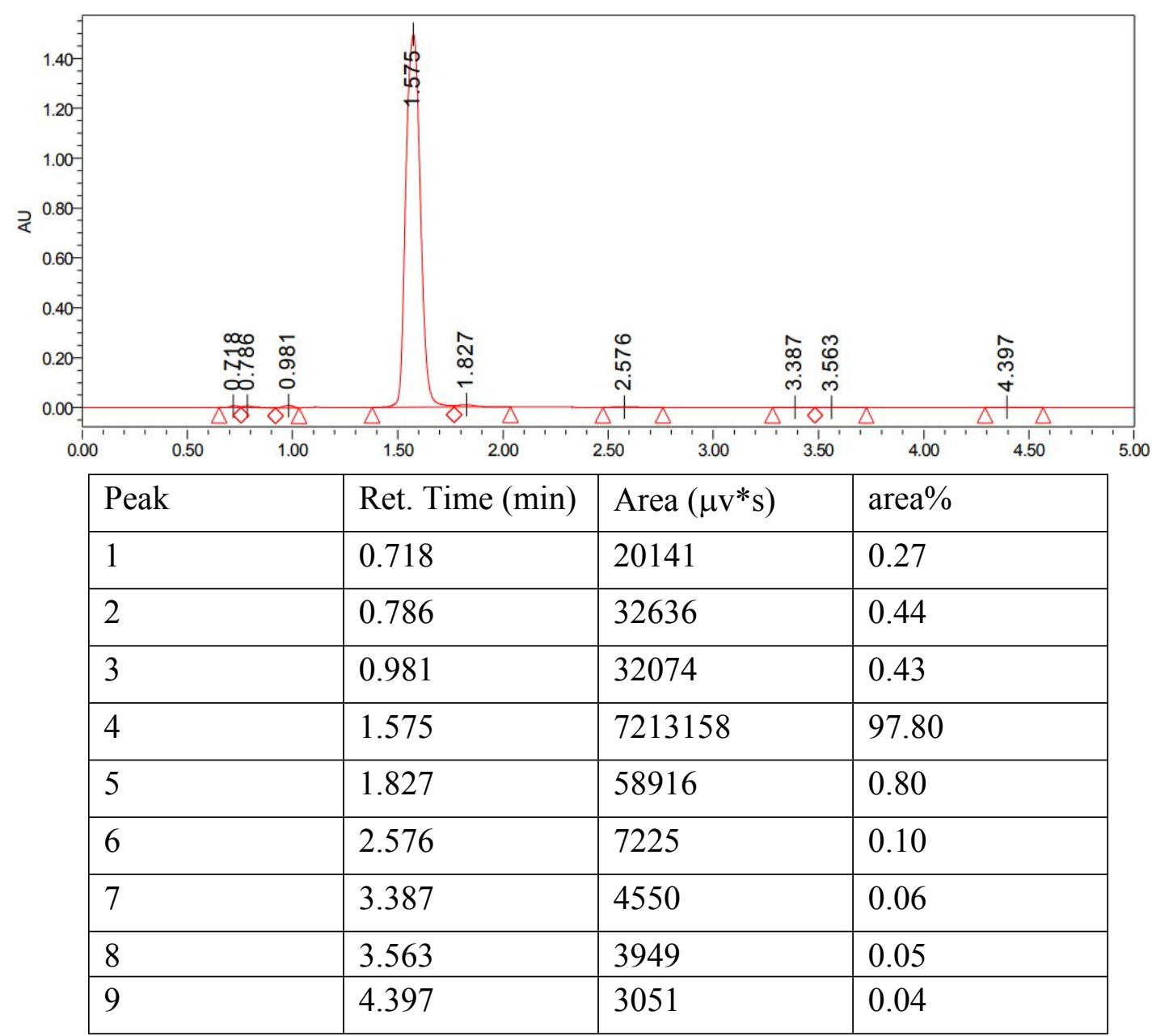


UPLC data of compound H28

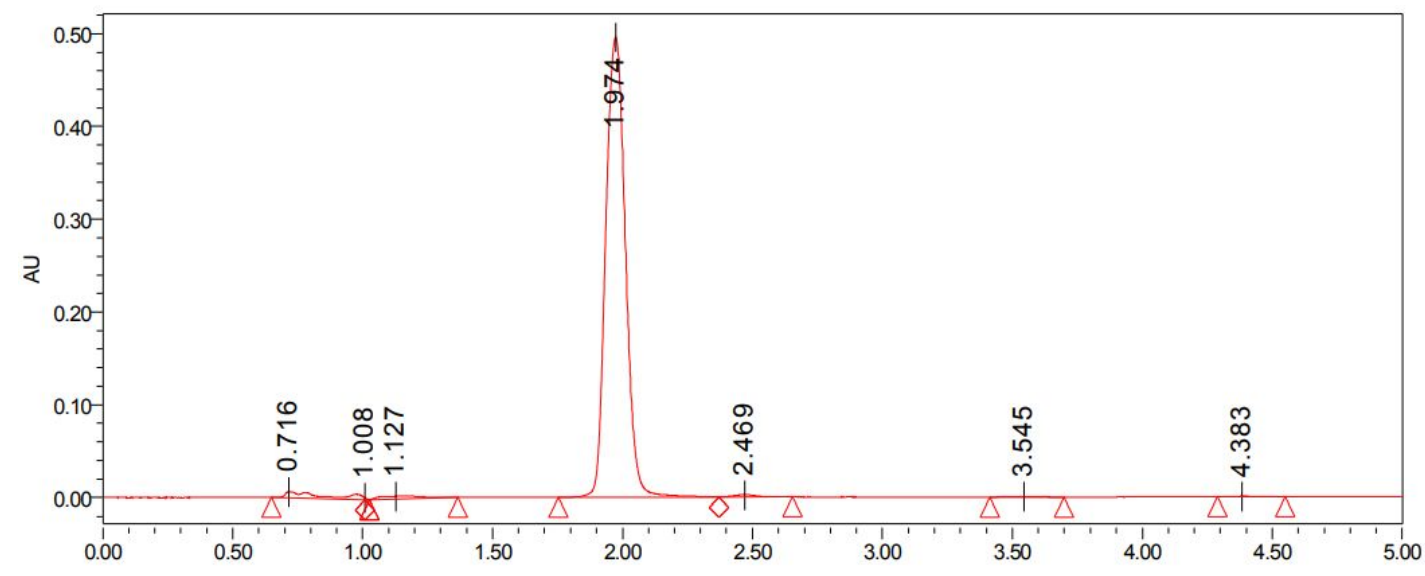

\begin{tabular}{|l|l|l|l|}
\hline Peak & Ret. Time $(\mathrm{min})$ & Area $\left(\mu \mathrm{v}^{*} \mathrm{~s}\right)$ & area $\%$ \\
\hline 1 & 0.716 & 72832 & 2.66 \\
\hline 2 & 1.008 & 718 & 0.03 \\
\hline 3 & 1.127 & 36173 & 1.32 \\
\hline 4 & 1.974 & 2606512 & 95.02 \\
\hline 5 & 2.469 & 16405 & 0.60 \\
\hline 6 & 3.545 & 7101 & 0.26 \\
\hline 7 & 4.383 & 3269 & 0.12 \\
\hline
\end{tabular}

UPLC data of compound H29

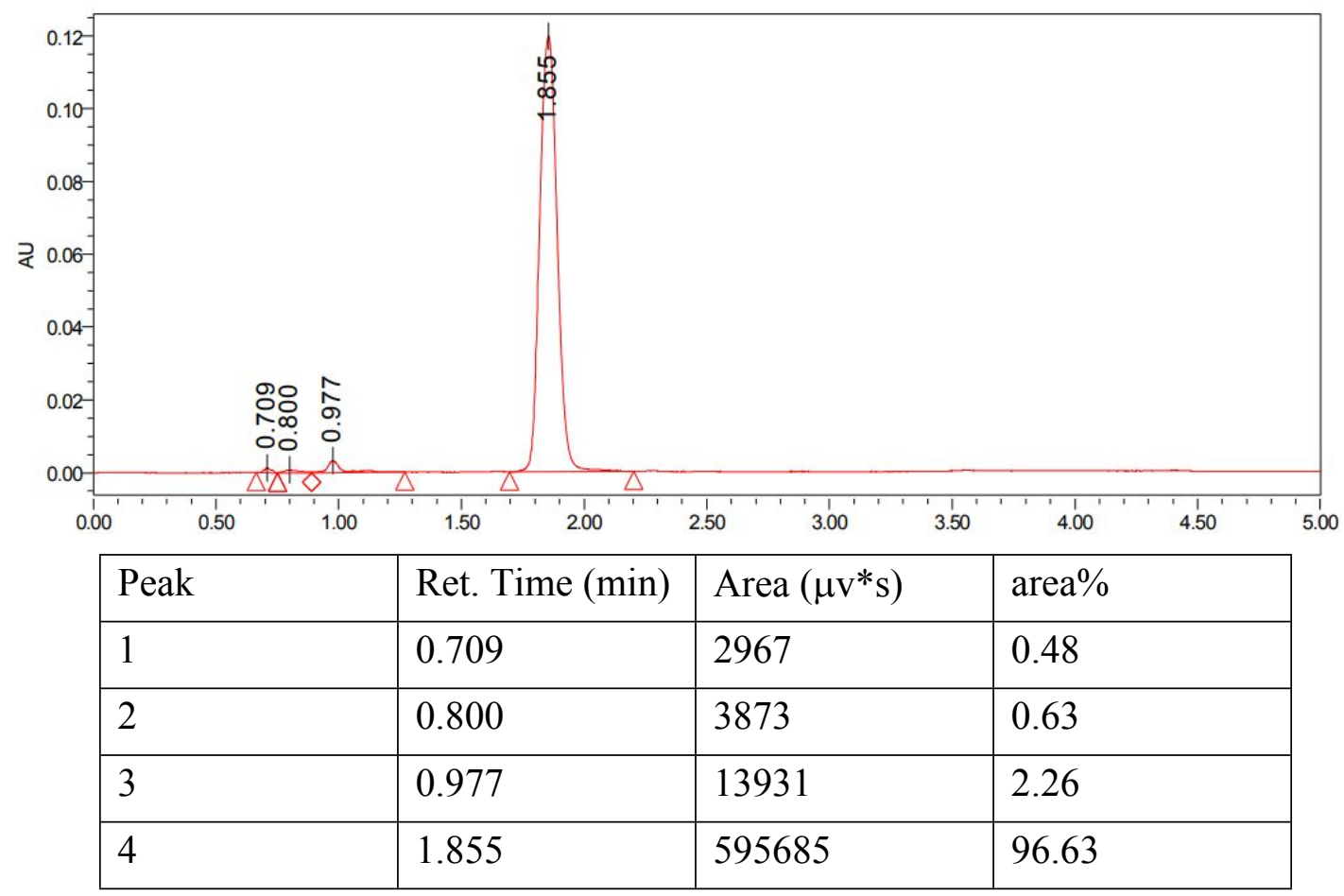


UPLC data of compound H30

\begin{tabular}{|l|l|l|l|}
\hline \\
\hline
\end{tabular}


UPLC data of compound H31

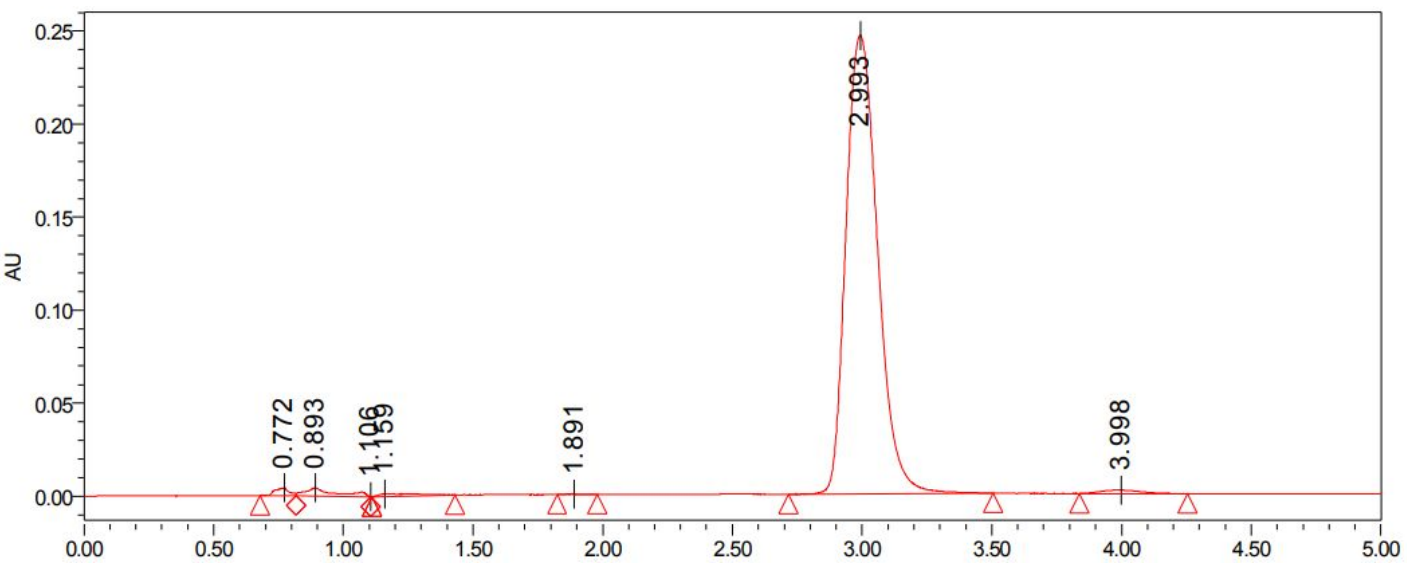

\begin{tabular}{|l|l|l|l|}
\hline Peak & Ret. Time $(\mathrm{min})$ & Area $\left(\mu \mathrm{v}^{*} \mathrm{~s}\right)$ & area $\%$ \\
\hline 1 & 0.772 & 16075 & 0.74 \\
\hline 2 & 0.893 & 37734 & 1.73 \\
\hline 3 & 1.106 & 4 & 0.00 \\
\hline 4 & 1.159 & 14586 & 0.67 \\
\hline 5 & 1.891 & 1122 & 0.05 \\
\hline 6 & 2.993 & 2085106 & 95.86 \\
\hline 7 & 3.998 & 20458 & 0.94 \\
\hline
\end{tabular}


UPLC data of compound H32

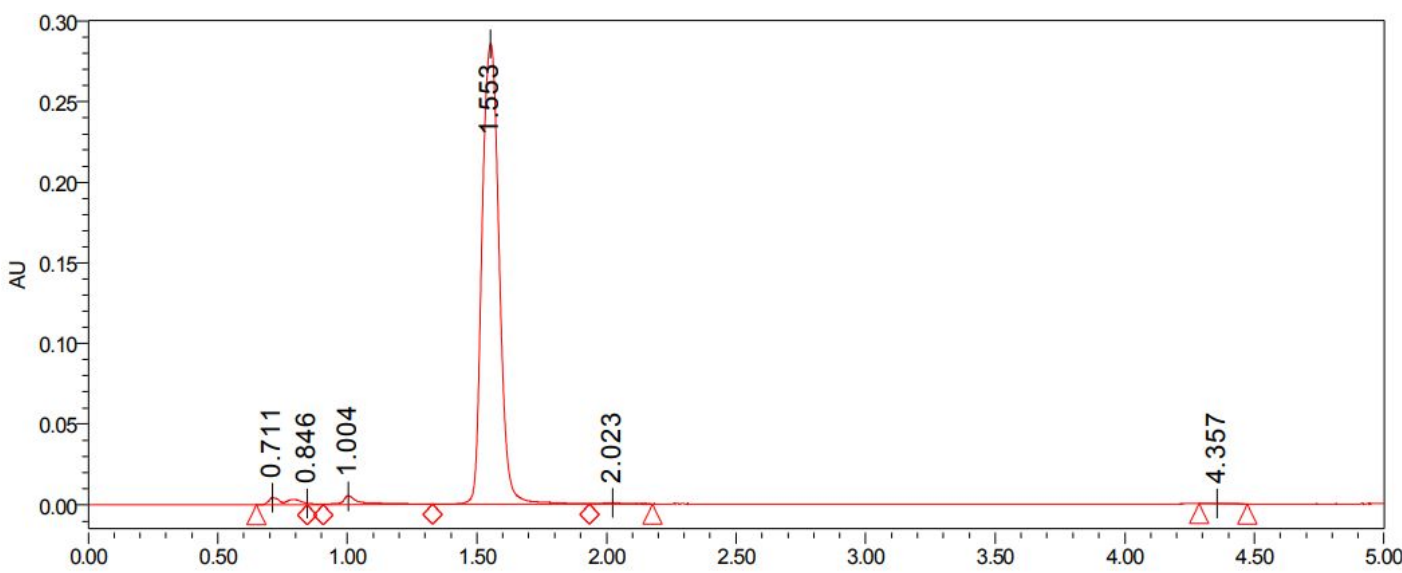

\begin{tabular}{|l|l|l|l|}
\hline Peak & Ret. Time $(\mathrm{min})$ & Area $\left(\mu \mathrm{v} \mathrm{s}^{\mathrm{s}}\right)$ & area $\%$ \\
\hline 1 & 0.711 & 23665 & 1.72 \\
\hline 2 & 0.846 & 1475 & 0.11 \\
\hline 3 & 1.004 & 26642 & 1.93 \\
\hline 4 & 1.553 & 1319626 & 95.74 \\
\hline 5 & 2.023 & 5203 & 0.38 \\
\hline 6 & 4.357 & 1734 & 0.13 \\
\hline
\end{tabular}


UPLC data of compound H33

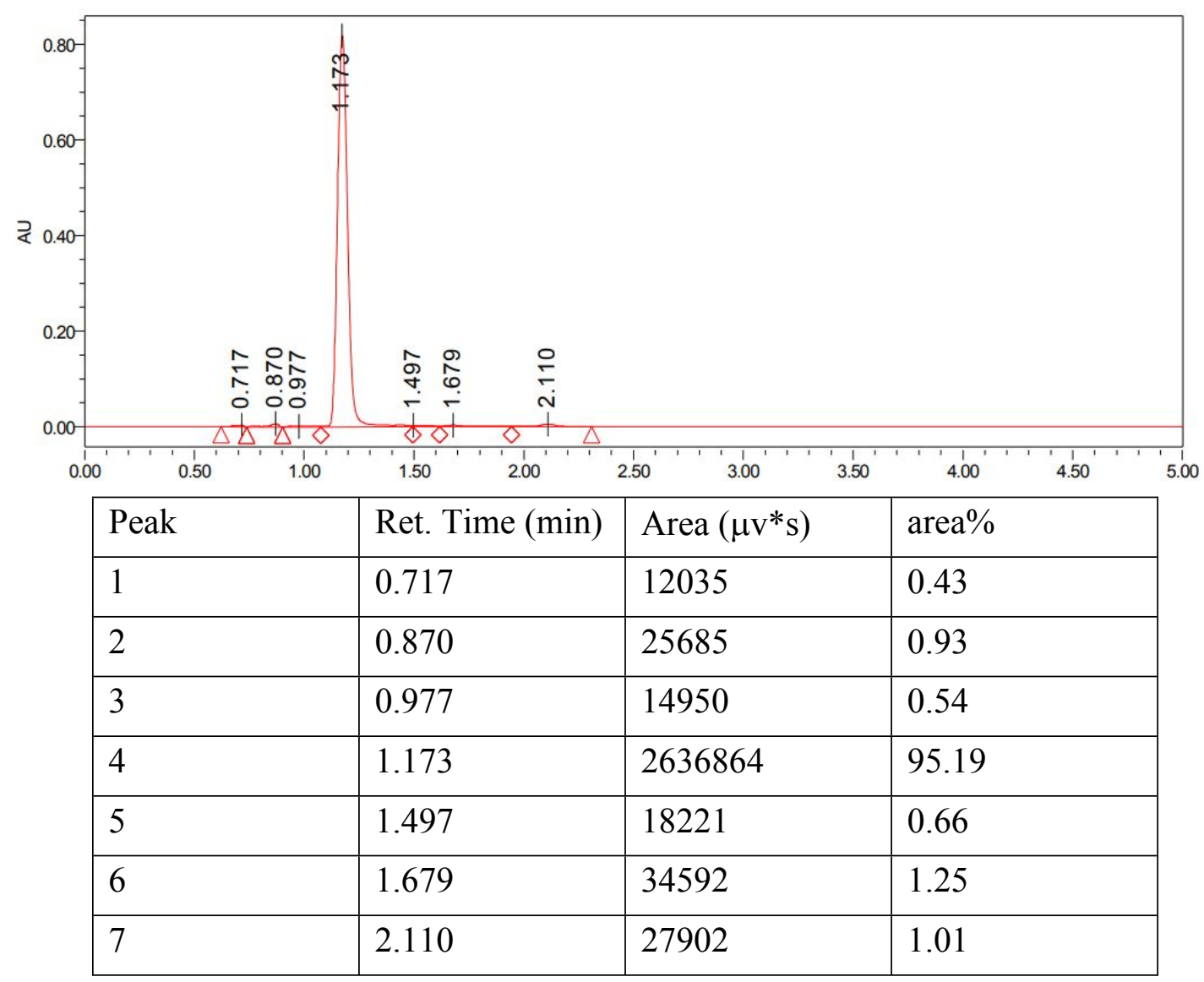


UPLC data of compound H34

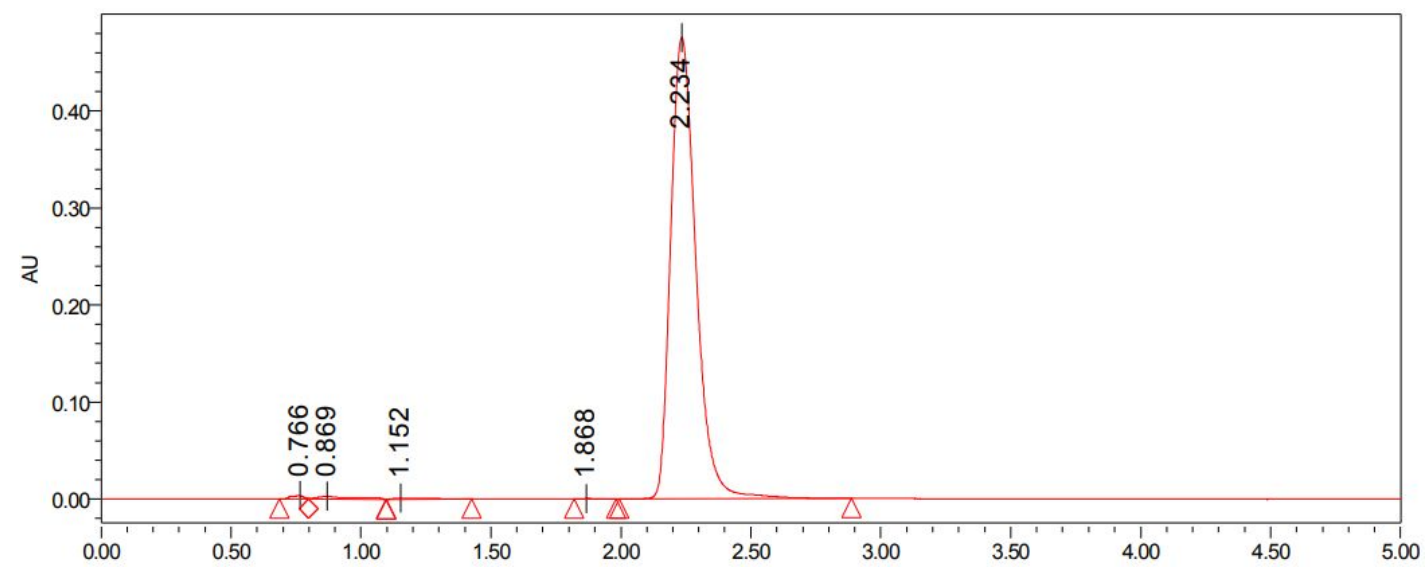

\begin{tabular}{|l|l|l|l|}
\hline Peak & Ret. Time $(\mathrm{min})$ & Area $\left(\mu \mathrm{v}^{*} \mathrm{~s}\right)$ & area $\%$ \\
\hline 1 & 0.766 & 12771 & 0.39 \\
\hline 2 & 0.869 & 33107 & 1.01 \\
\hline 3 & 1.152 & 13627 & 0.41 \\
\hline 4 & 1.868 & 1501 & 0.05 \\
\hline 5 & 2.234 & 3224934 & 98.14 \\
\hline
\end{tabular}


UPLC data of compound H35

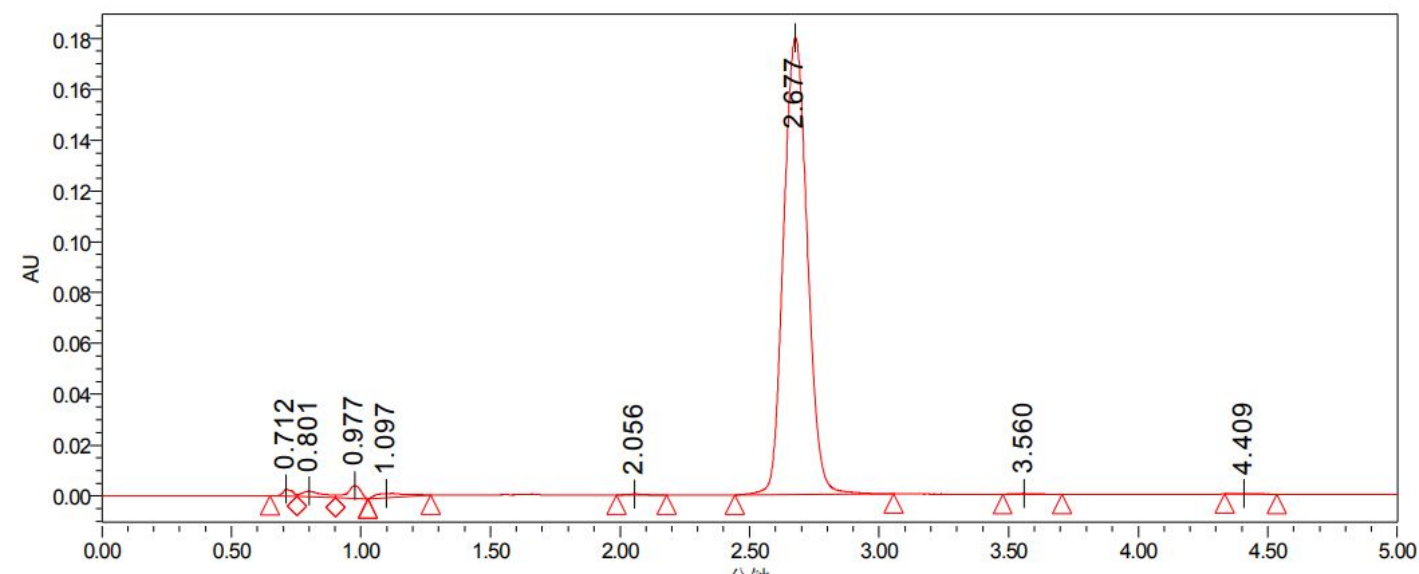

\begin{tabular}{|l|l|l|l|}
\hline Peak & Ret. Time $(\min )$ & Area $\left(\mu \mathrm{v}^{*} \mathrm{~s}\right)$ & area $\%$ \\
\hline 1 & 0.712 & 7063 & 0.59 \\
\hline 2 & 0.801 & 12763 & 1.06 \\
\hline 3 & 0.977 & 18092 & 1.50 \\
\hline 4 & 1.097 & 13353 & 1.11 \\
\hline 5 & 2.056 & 2015 & 0.17 \\
\hline 6 & 2.677 & 1145224 & 95.22 \\
\hline 7 & 3.560 & 2277 & 0.19 \\
\hline 8 & 4.409 & 1884 & 0.16 \\
\hline
\end{tabular}


UPLC data of compound H36

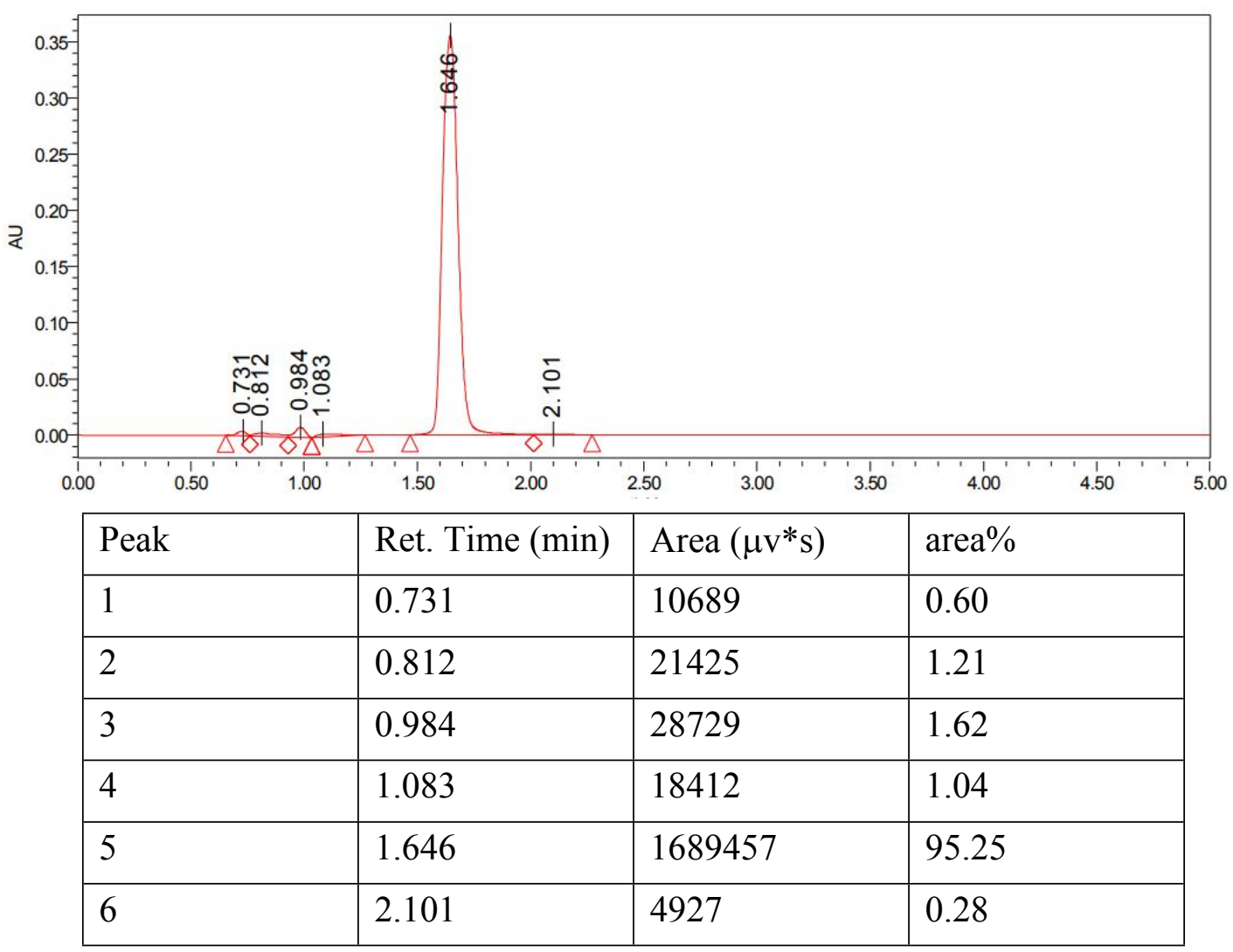


UPLC data of compound H37

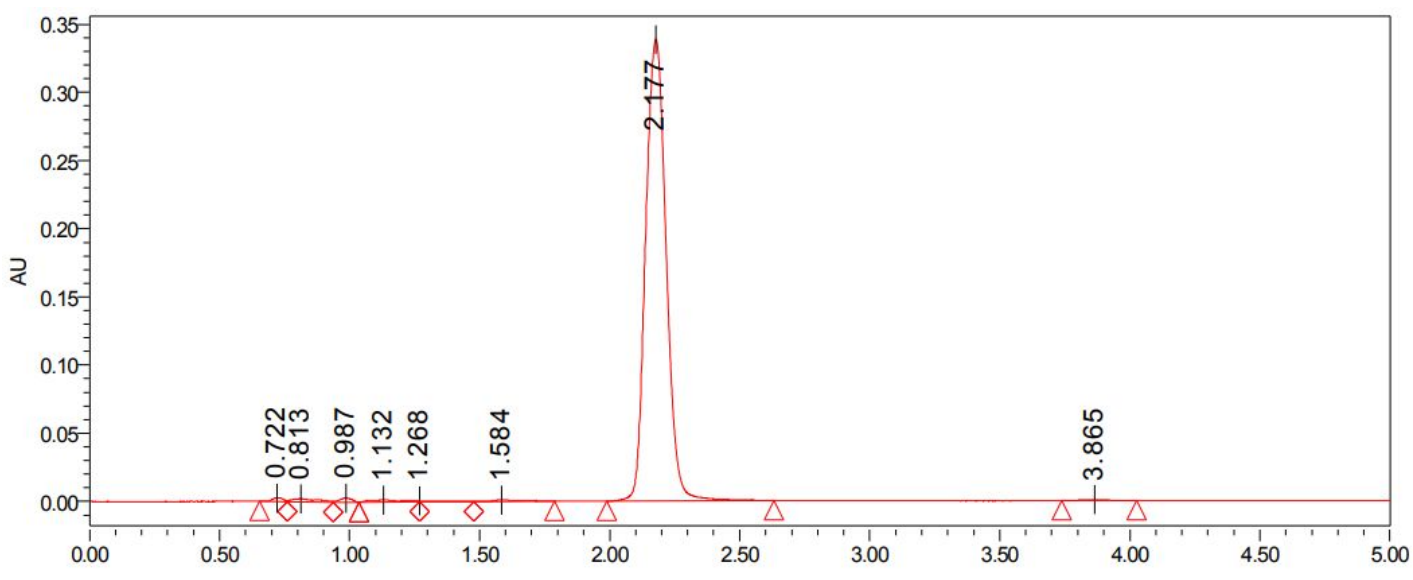

\begin{tabular}{|l|l|l|l|}
\hline Peak & Ret. Time (min) & Area $\left(\mu \mathrm{v}^{*} \mathrm{~s}\right)$ & area\% \\
\hline 1 & 0.722 & 8003 & 0.42 \\
\hline 2 & 0.813 & 15722 & 0.82 \\
\hline 3 & 0.987 & 10431 & 0.54 \\
\hline 4 & 1.132 & 16145 & 0.84 \\
\hline 5 & 1.268 & 7627 & 0.40 \\
\hline 6 & 1.584 & 9180 & 0.48 \\
\hline 7 & 2.177 & 1854156 & 96.22 \\
\hline 8 & 3.865 & 5676 & 0.29 \\
\hline
\end{tabular}


UPLC data of compound H38

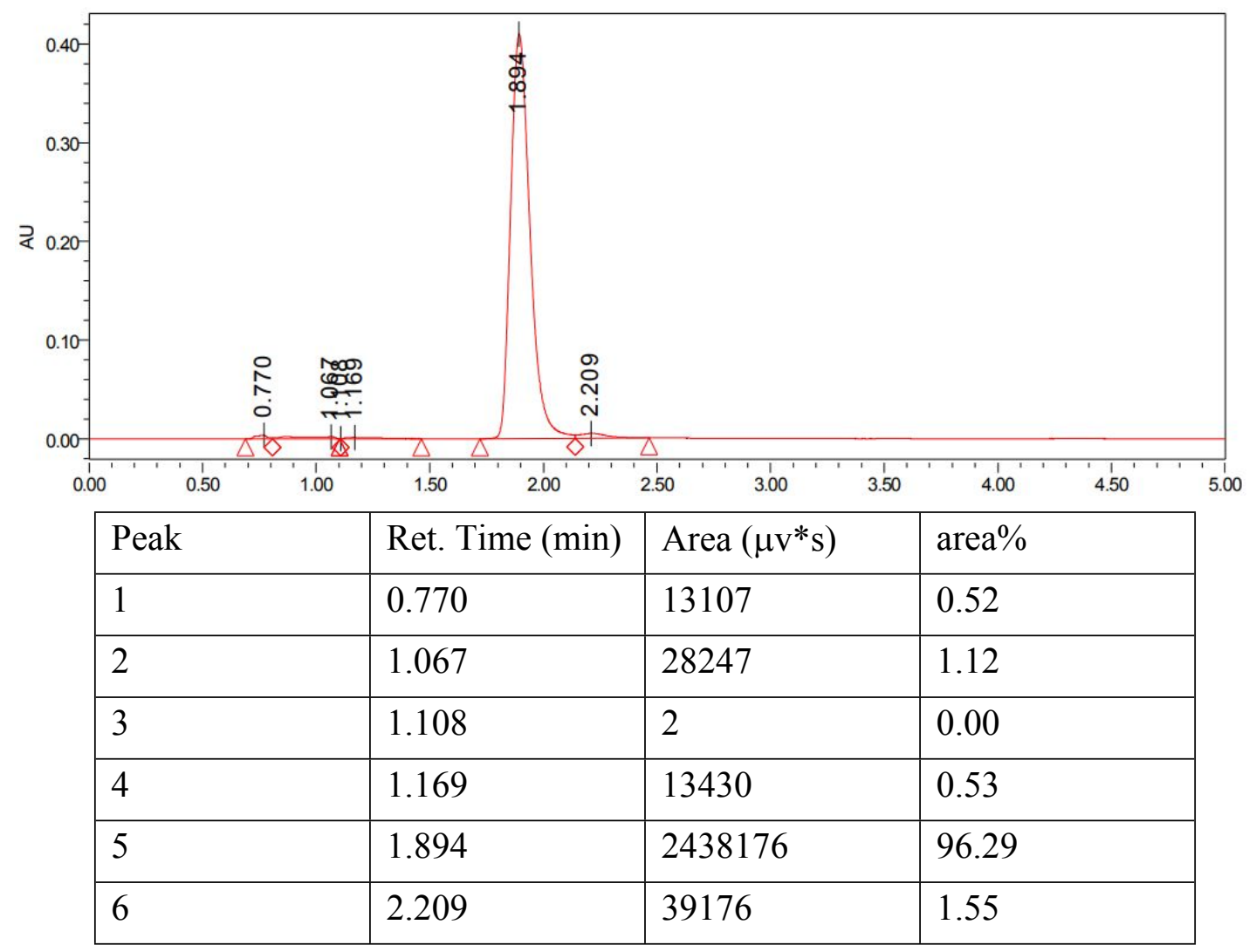


UPLC data of compound H39

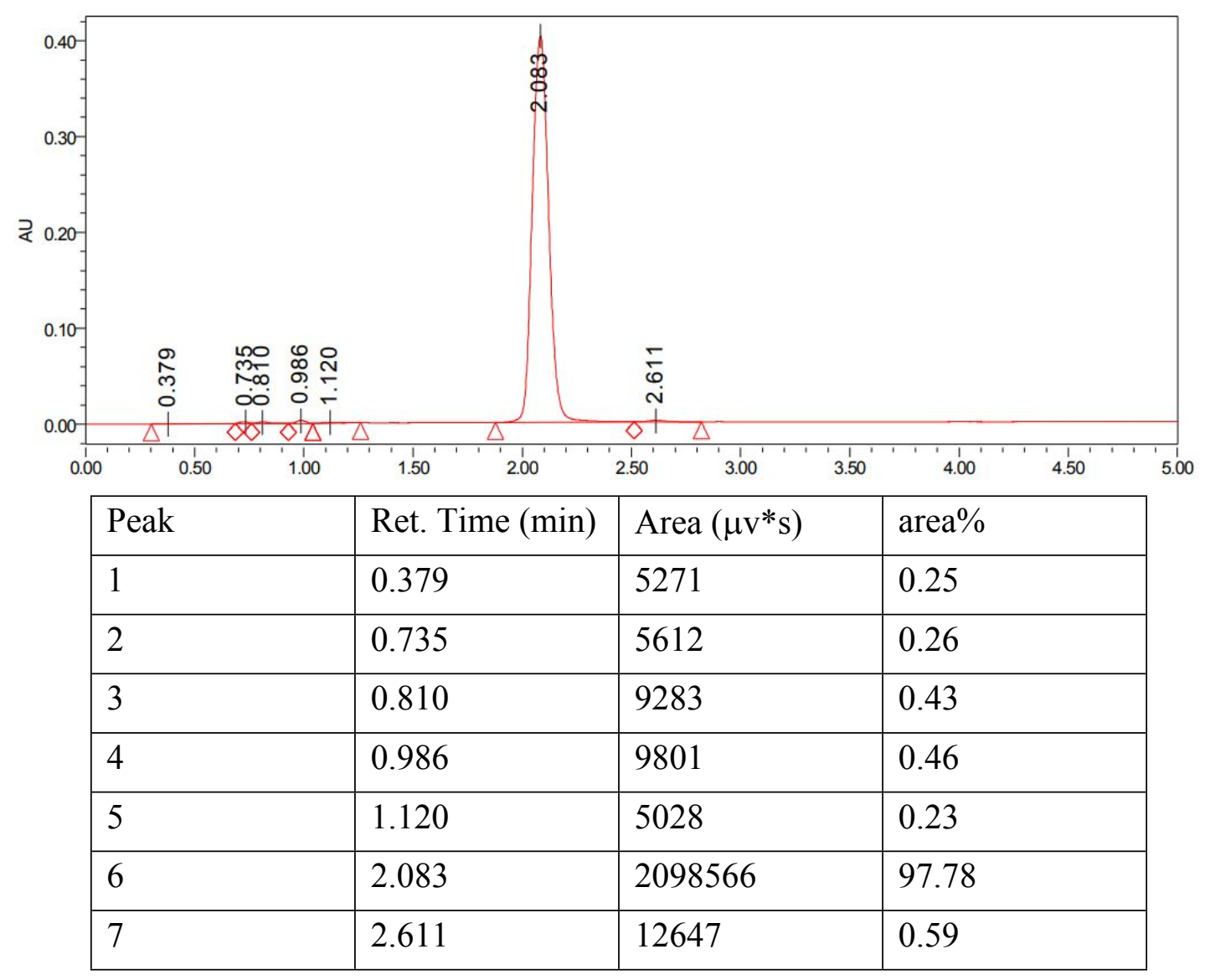


UPLC data of compound H40

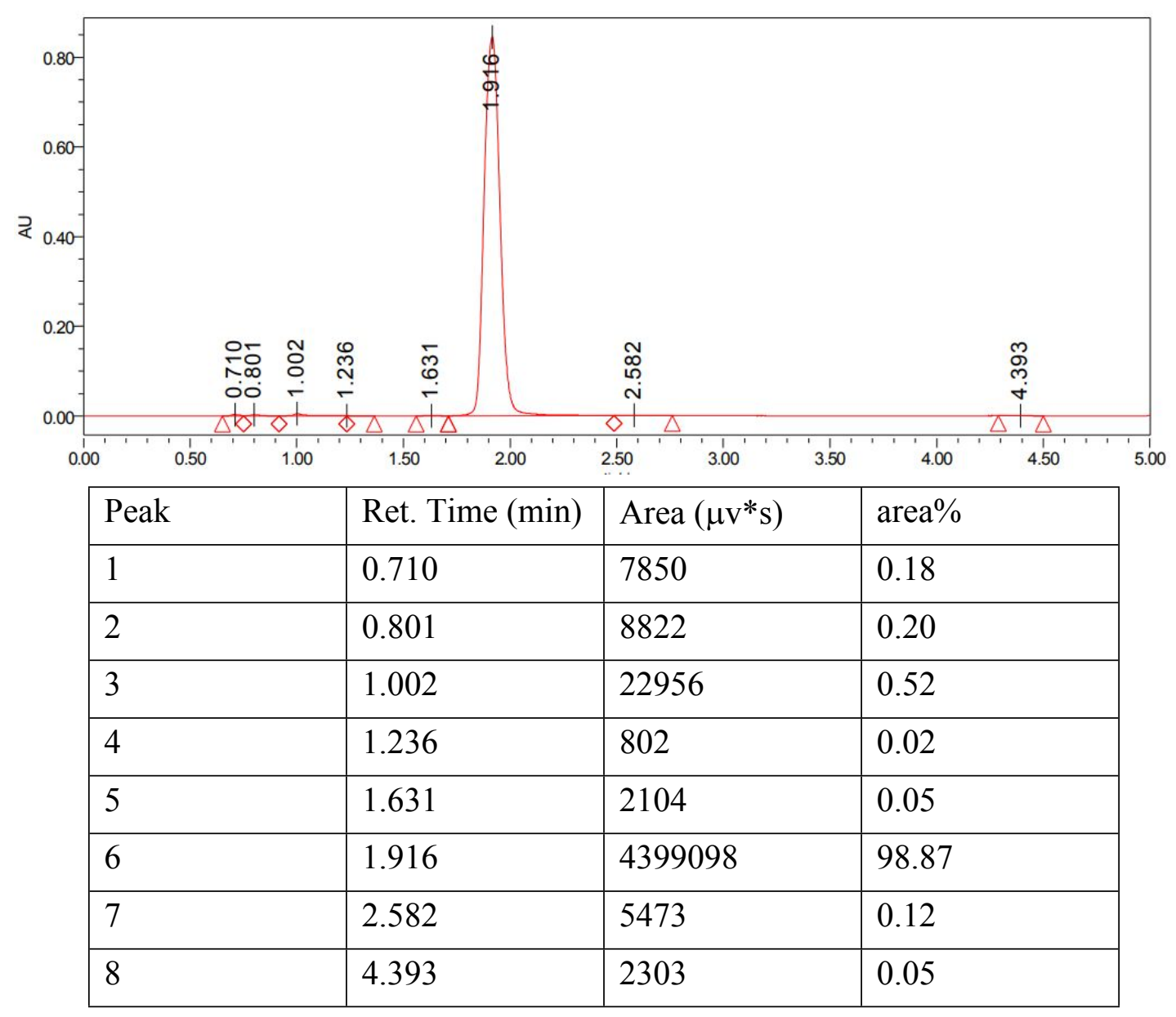


UPLC data of compound H41

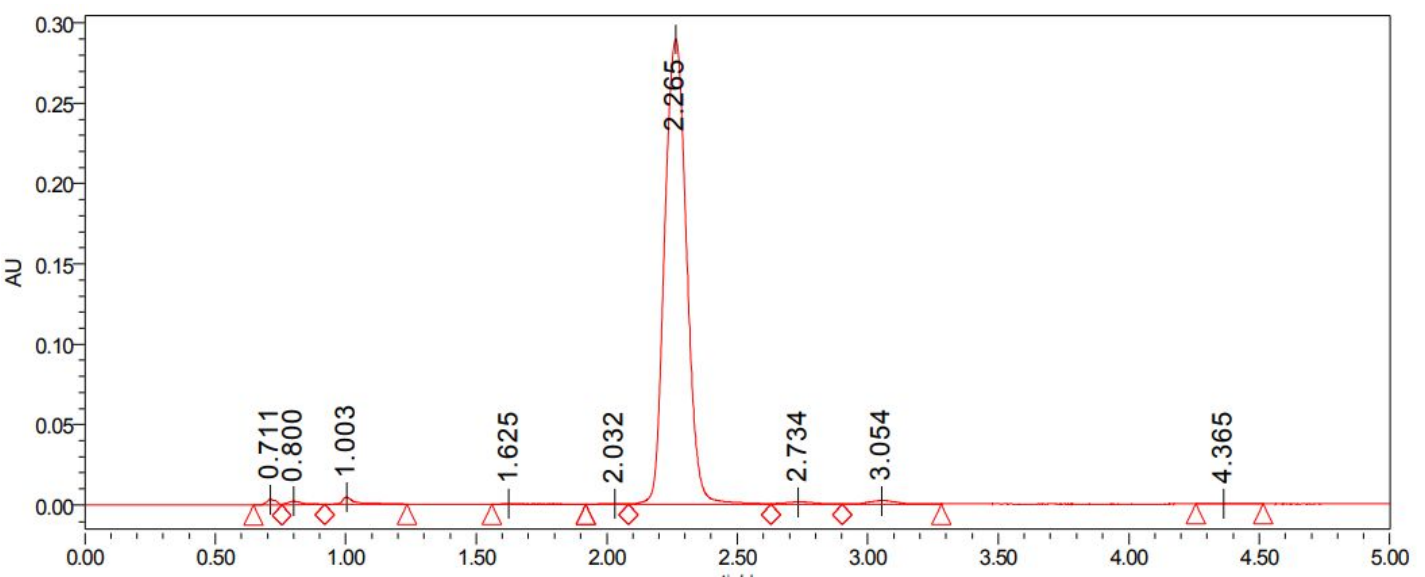

\begin{tabular}{|l|l|l|l|}
\hline Peak & Ret. Time $(\min )$ & Area $\left(\mu \mathrm{v}^{*} \mathrm{~s}\right)$ & area\% \\
\hline 1 & 0.711 & 8308 & 0.47 \\
\hline 2 & 0.800 & 8886 & 0.50 \\
\hline 3 & 1.003 & 18218 & 1.03 \\
\hline 4 & 1.625 & 4248 & 0.24 \\
\hline 5 & 2.032 & 2981 & 0.17 \\
\hline 6 & 2.265 & 1695708 & 95.74 \\
\hline 7 & 2.734 & 12819 & 0.72 \\
\hline 8 & 3.054 & 16864 & 0.95 \\
\hline 9 & 4.365 & 3041 & 0.17 \\
\hline
\end{tabular}


UPLC data of compound H42

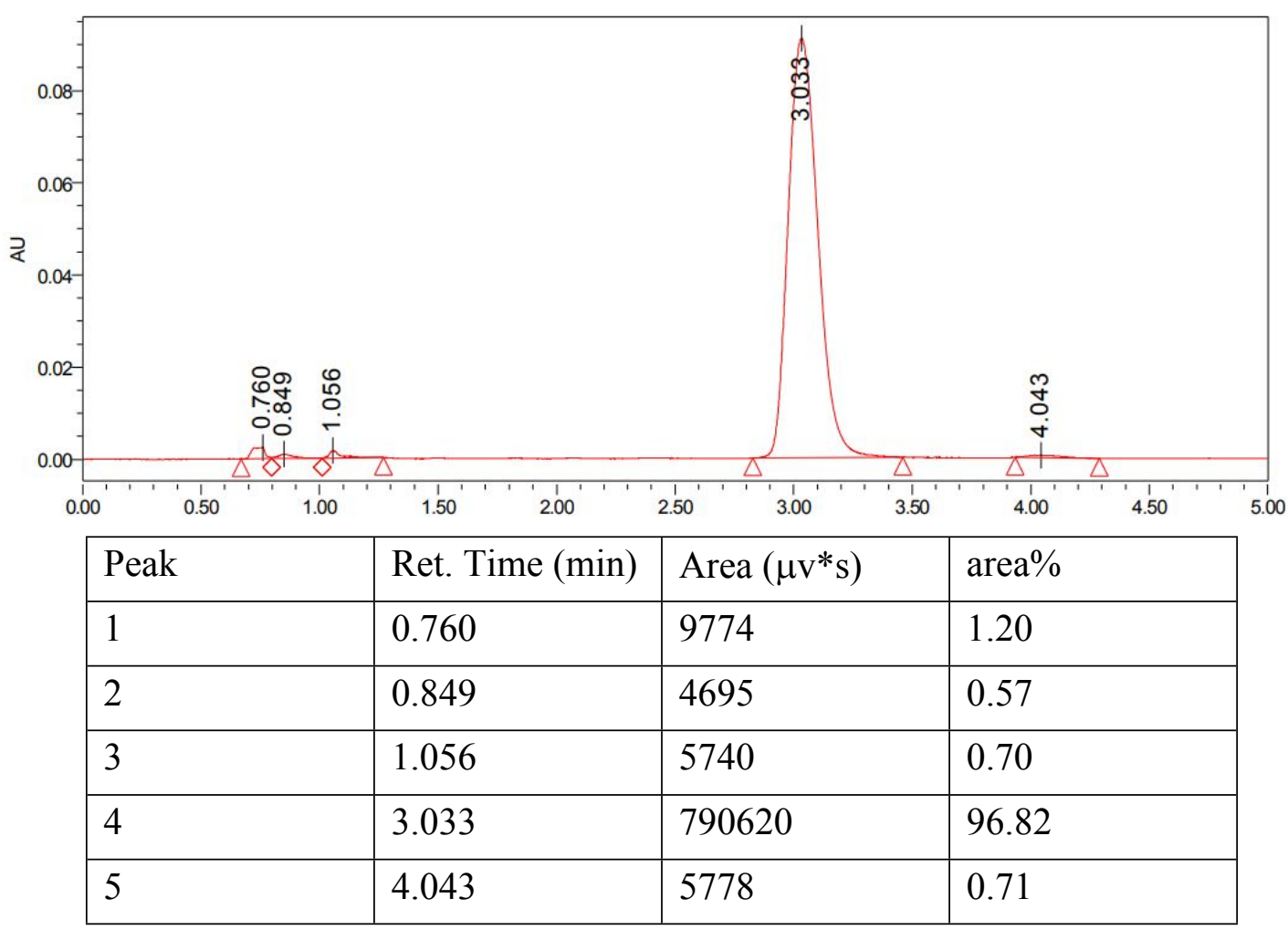




\section{UPLC Data of GFT-505, IVA-337 and compound 8}

UPLC data of compound GFT-505

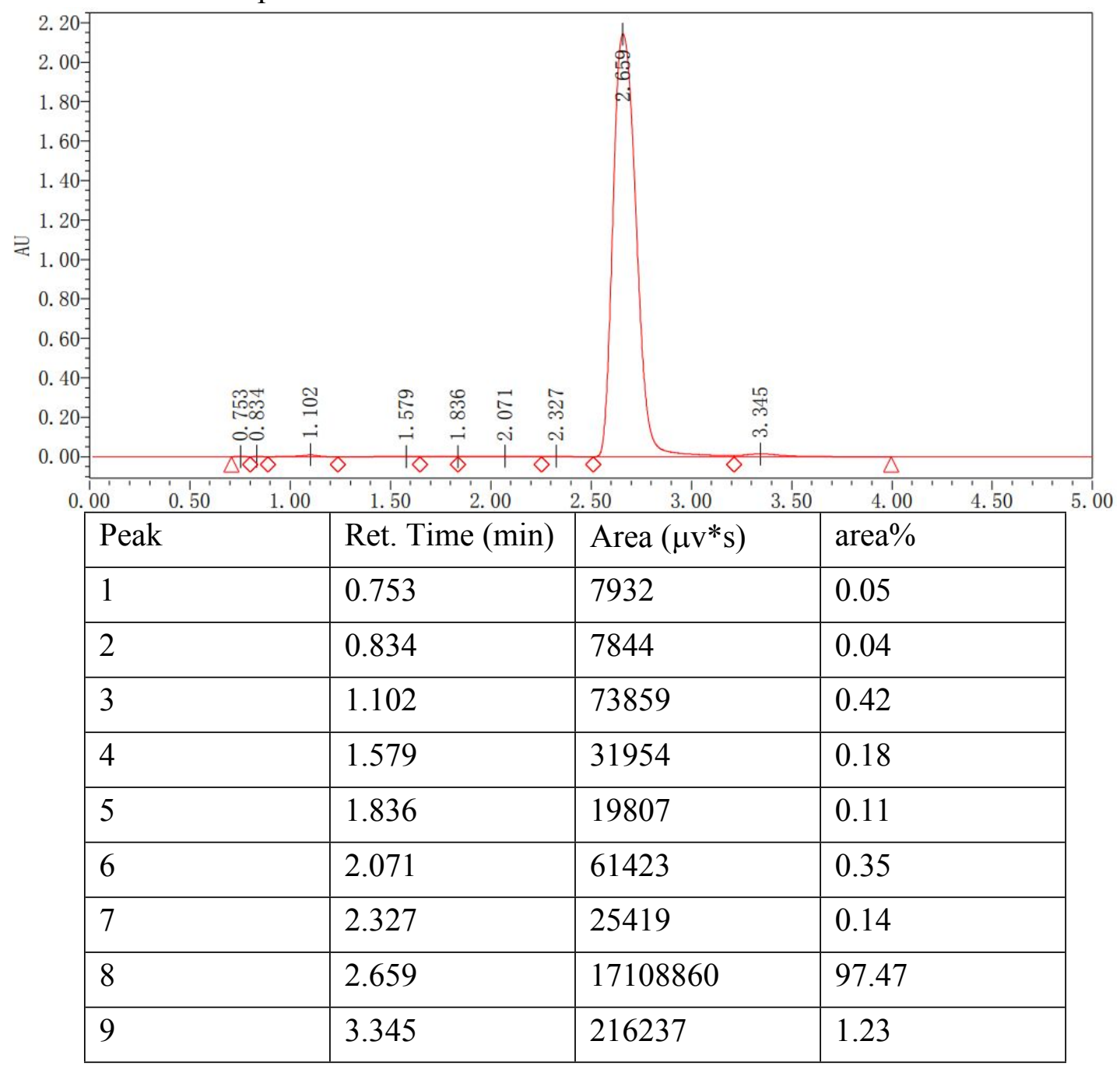


UPLC data of compound IVA-337

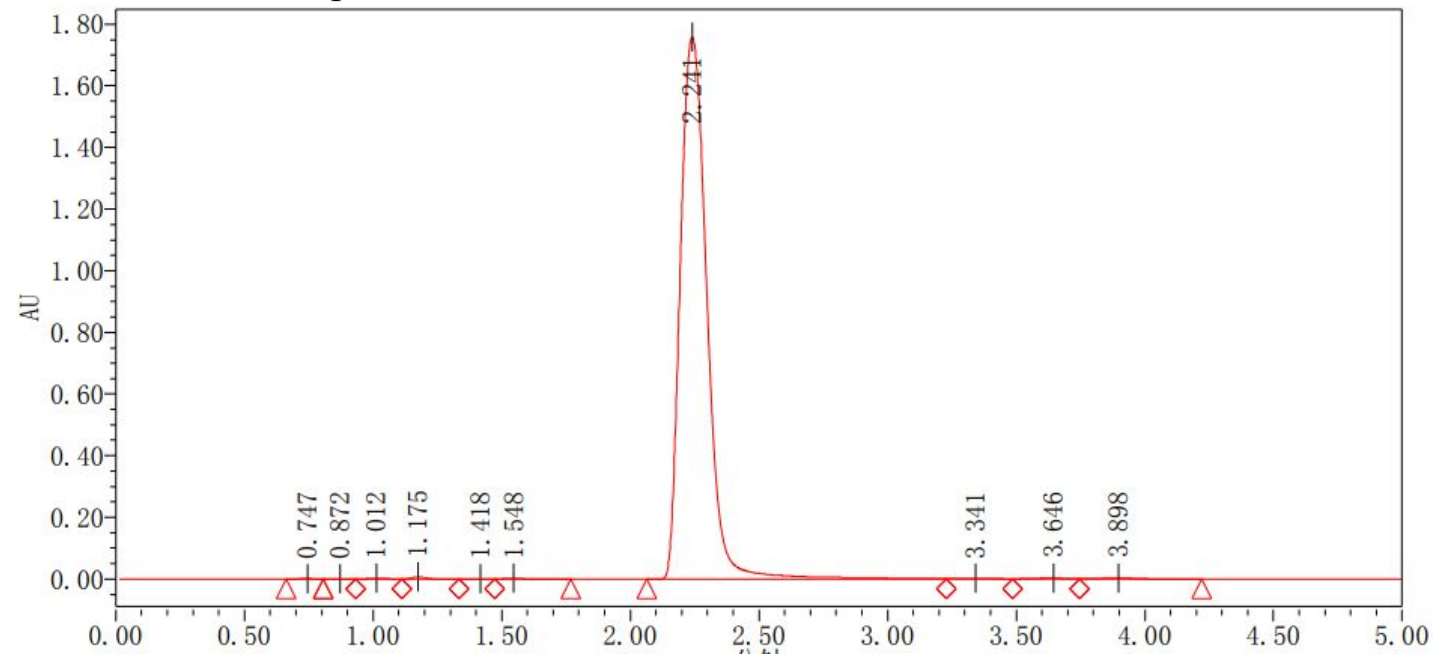

\begin{tabular}{|l|l|l|l|}
\hline Peak & Ret. Time $(\mathrm{min})$ & Area $\left(\mu \mathrm{v}^{*} \mathrm{~s}\right)$ & area\% \\
\hline 1 & 0.747 & 7817 & 0.06 \\
\hline 2 & 0.872 & 9636 & 0.07 \\
\hline 3 & 1.012 & 20335 & 0.16 \\
\hline 4 & 1.175 & 33530 & 0.26 \\
\hline 5 & 1.418 & 8318 & 0.06 \\
\hline 6 & 1.548 & 15791 & 0.12 \\
\hline 7 & 2.241 & 12660083 & 98.17 \\
\hline 8 & 3.341 & 35996 & 0.28 \\
\hline & & $\mathrm{s} 101$ & \\
\hline
\end{tabular}




\begin{tabular}{|l|l|l|l|}
\hline 9 & 3.646 & 46070 & 0.36 \\
\hline 10 & 3.898 & 58427 & 0.45 \\
\hline
\end{tabular}


UPLC data of compound 8

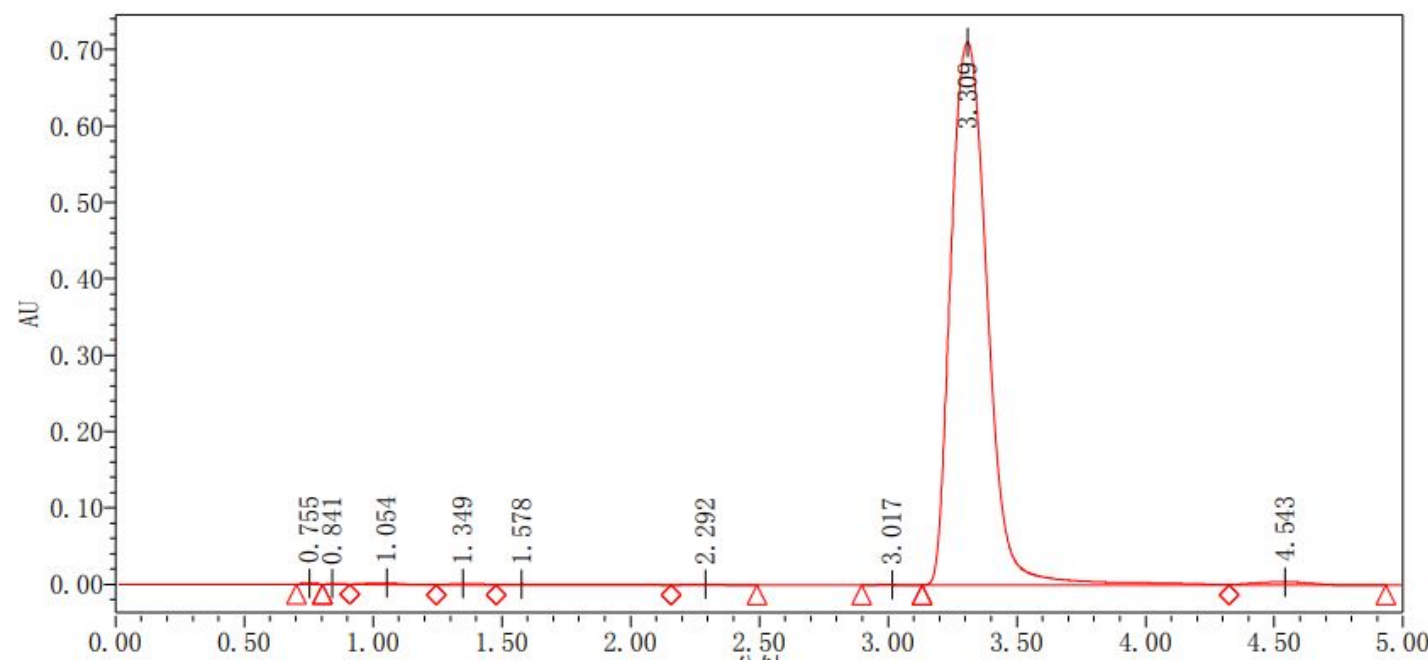

\begin{tabular}{|l|l|l|l|}
\hline Peak & Ret. Time $(\min )$ & Area $\left(\mu \mathrm{v}^{*} \mathrm{~s}\right)$ & area\% \\
\hline 1 & 0.755 & 7662 & 0.11 \\
\hline 2 & 0.841 & 5713 & 0.08 \\
\hline 3 & 1.054 & 23148 & 0.32 \\
\hline 4 & 1.349 & 12394 & 0.17 \\
\hline 5 & 1.578 & 24071 & 0.33 \\
\hline 6 & 2.292 & 6483 & 0.09 \\
\hline 7 & 3.017 & 2325 & 0.03 \\
\hline 8 & 3.309 & 7033160 & 97.82 \\
\hline 9 & 4.543 & 7841 & 1.04 \\
\hline
\end{tabular}

